UNIVERSIDADE DE SÃO PAULO

FACULDADE DE FILOSOFIA, LETRAS E CIÊNCIAS HUMANAS

FABRICIO VASSELAI

A locomotiva silenciosa: o não predomínio da política paulista na democracia de 1945

(versão corrigida) 


\section{A locomotiva silenciosa: o não predomínio da política paulista na democracia de 1945}

(versão corrigida)

\section{FABRICIO VASSELAI}

Dissertação apresentada ao Departamento de Ciência Política da Faculdade de Filosofia, Letras e Ciências Humanas, para a obtenção do título de Mestre em Ciência Política

Orientador: Prof.Dr. Gildo Marçal Brandão 
à Analice e ao Rennan

à Paula Rondinelli 


\section{Agradecimentos}

Como a cada novo obstáculo que surgia durante a realização deste trabalho aparecia também uma nova fonte de ajuda, não poderei e nem mesmo conseguiria agradecer nominalmente a todas as pessoas que tornaram possível a realização desta pesquisa. Sublinho aqui apenas algumas delas que estiveram presentes com mais recorrência, sem prejuízo das outras muitas e daqueles que, com seu trabalho silencioso e muitas vezes anônimo, tornam possível que toda uma estrutura de trabalho funcione.

Sou grato em primeiro lugar e acima de tudo ao meu orientador, Gildo Marçal Brandão. Gildo não apenas encampou minha proposta de pesquisa polêmica e difícil de ser realizada, como também, para fazer isso, teve de confiar em meu trabalho. E realmente confiou: permitiu-me liberdade teórica e metodológica, apostou mais de uma vez em meu potencial, orientou-me com rigor e substância de quem acreditava poder exigir de mim sempre o melhor. Gildo é daqueles raros intelectuais que conseguem desprender-se verdadeiramente de seus próprios paradigmas, aceitam a diversidade de perspectivas e estão abertos àquela interdisciplinaridade que impede a excessiva especialização. Jamais viu como obstáculo que eu tentasse incluir em meu trabalho uma literatura ou um viés analítico diferentes de sua área de atuação. Jamais se opôs a que eu continuasse me interessando pela Ciência Política como um todo, não exigindo de mim a estreiteza de um escaninho intelectual precoce. Gildo foi compreensivo com todas as muitas dificuldades, inclusive pessoais, mesmo sem que eu precisasse contá-las. Sua orientação culta de quem domina a literatura com esmero e sua compreensão tácita foram os alicerces mais inestimáveis que poderia desejar.

Nesse processo de pesquisa, recebi muitas outras contribuições intelectuais pelas quais sou imensamente grato. Agradeço especialmente ao apoio e às imprescindíveis sugestões que 
recebi de Maria D’Alva Gil Kinzo, à leitura de meu trabalho e aos comentários feitos pelos professores Fernando Abrúcio e Maria Tereza Sadek, aos diálogos que estabeleci sobre meu tema com o amigo e colega André Nogueira, às leituras da grande amiga Paula Rondinelli, às reuniões de pesquisa e aos Workshops do Projeto Temático da Fapesp "Linhagens do Pensamento Político-Social Brasileiro", às conversas sobre métodos e técnicas de pesquisa que sempre tive com meu amigo e colega Umberto Guarnier Mignozzetti, a conversas esclarecedoras que tive com Fernando Limongi sobre a política de 1945-64. Agradeço de maneira mais geral ao apoio dado à minha carreira durante esta pesquisa por parte dos professores Maria do Socorro Souza Braga, Leandro Piquet Carneiro, Maria Hermínia Tavares de Almeida e à confiança inicial da professora Rita de Cássia Ariza da Cruz. Sou grato ao professor Rafael Duarte Villa pela atenção e especialmente por sua compreensão.

Gostaria de registrar o papel capital representado pelo trabalho dos funcionários do Departamento de Ciência Política da USP. Sua atuação de bastidores faz a casa funcionar. Mas quero agradecê-los nominalmente: à Ana Maria, à Márcia e ao Léo, que tantas vezes ajudaram a resolver todos os tipos de problemas. E especialmente à Vivian, que esteve presente em todas as vezes em que eu me ausentei, e à Rai, sem a qual esta dissertação literalmente não teria sido finalizada e entregue. Além de competente, Rai possui um companheirismo profissional e um espírito de equipe incríveis.

Agradeço a uma série de materiais, informações e dados que coletei e recebi de diversas instituições e pessoas. Agradeço à Secretaria Geral da Presidência da República, ao IBGE, ao IUPERJ, à FUNDAP, à Biblioteca do Senado, à Seção de Dados da Câmara Federal, à Fundação Seade, à Biblioteca Central do Rio de Janeiro, às Bibliotecas da Faculdade de Direito, do IEB-Usp, da FEA-Usp e da FAU-Usp. Especialmente, sou grato aos funcionários da Biblioteca Florestan Fernandes, da FFLCH. Agradeço também por alguns dados cedidos por Jairo Nicolau, por Otavio Amorim Neto e por Argelina Figueiredo. 
E é claro, não poderia deixar de agradecer a algumas pessoas sem as quais esta dissertação não existiria por falta de condições não-acadêmicas. Agradeço à presença sempre solícita de meu grande amigo Murilo Machado Sampaio Ferraz. Sou grato à querida Célia Wagner por literalmente me ajudar a manter minha saúde nos eixos. E ao meu grande amigo Leandro Fontes por uma série impagável de ajudas. Leandro tornou meus últimos doze meses exeqüíveis e o fez sempre com a maior dedicação. Ao meu irmão Rennan e à minha mãe Analice sou grato por coisas demais para descrever aqui. Seria mais outra dissertação. Obrigado aos dois por existirem, por me darem referência e por sonharem meus sonhos comigo. Ela é responsável por tudo que sou; e ele, pelo que quero ser. Espero que este trabalho anime-os por um dia.

Por fim, sou especialmente grato à Paula Rondinelli. Nada do que consegui em âmbito algum seria possível sem ela. Todas as páginas desta dissertação e de meus últimos anos foram escritos com seu apoio, com sua dedicação, com seu carinho. Paula me manteve firme, mas sem perder a ternura jamais. Devo a ela minha permanência na faculdade, a opção pelo mestrado, o cuidado com a saúde, a resiliência em geral. A bondade e a amizade de Paula afrontam diuturnamente meu ceticismo de cientista político. É daquelas pessoas que, como o rio Capiberibe do Severino, nos faz querer sempre seguir em frente novamente à procura do mar.

Sou grato ainda à FAPESP pelo auxílio financeiro de sua Bolsa de Mestrado, concedida sobre o processo $n^{\circ} 2007 / 52408-2$. Permitiu minha resistência e a participação em eventos internacionais inestimáveis. O papel dessas bolsas de pesquisa é, realmente, vital. 


\section{Resumo}

\section{VASSELAI, F. A locomotiva silenciosa: o não predomínio da política paulista na}

democracia de 1945. 222 f. Dissertação (Mestrado) - Departamento de Ciência Política, Faculdade de Filosofia, Letras e Ciências Humanas da Universidade de São Paulo, 2009.

Esta pesquisa tem como objetivo central qualificar o suposto declínio da política paulista em relação à política nacional, depois de 1930 e principalmente na democracia de 1945-64, para então investigar quais as possíveis causas que levaram a esse resultado. Propõese que o significado desse ocaso político dos paulistas não é tão evidente quanto a literatura política costuma julgar e, por isso, deve ser especificado: apesar de Vargas ascender em meio a um projeto de re-equilíbrio das forças regionais, contra o predomínio de São Paulo, o varguismo e o posterior desenvolvimentismo ensejaram mudanças sócio-econômicas que beneficiaram diversos interesses paulistas, cujos representantes nunca deixaram de influir nos negócios nacionais. Mesmo assim, é possível identificar como problema central o fato de nem os quadros políticos paulistas conseguirem nacionalizar-se, nem os partidos nacionais ali se consolidarem. As causas disso, sugere-se como hipótese, estariam ligadas à: 1- em momento pouco claro sobre ganhos econômicos do modelo varguista, mas certo sobre a ameaça política representada por Vargas, paulistas no Estado Novo geralmente se contrapõem ou afastam do varguismo, dificultando estruturar partidos a partir da máquina estatal como ocorria alhures; 2- São Paulo já beneficiado pelo industrialismo, sua política contudo é marcada pela dependência da trajetória: produz nomes fortes pouco identificados com o desenvolvimentismo, contra a demanda eleitoral do país; 3- o PTB em São Paulo sofre a intervenção dos varguistas temerosos com o crescimento do partido no estado e sofre com a concorrência de movimentos sociais independentes do varguismo Especilamente o PCB prejudica penetração do PTB em São Paulo e, ilegalizado, morre única força não fragmentada nacionalizável no estado.

Palavras-chave: Política paulista; Democracia de 1945; São Paulo; Partidos paulistas; formação partidária. 


\section{Abstract}

\section{VASSELAI, F. Silent locomotive: the non-predominance of paulista politics in the}

Brazilian democracy of 1945-64. 222 f. Dissertation (Master) - Departamento de Ciência Política, Faculdade de Filosofia, Letras e Ciências Humanas da Universidade de São Paulo, 2009.

This research aims to specify what was indeed the supposed loss of the paulista politics' importance in the Brazilian politics after 1930 and, mainly, in the democratic period of 1945-64. Just then, this work will aim to investigate which possible causes explain that phenomenon. I propose the meaning of that political decline of the paulistas is not so evident as the political literature usually presumes and, therefore, it should be detailed: although Vargas arose trough a project of re-equilibration of regional forces against São Paulo predominance, the varguismo and the posterior desenvolvimentismo brought social-economic changes that benefited varied paulista interests - whose representatives never ended completely their influence towards national affairs. Even so, it is possible to identify the central question as being the fact that nor did the paulista politicians nationalized themselves, nor did the national parties consolidated in Sao Paulo. The reasons suggested by this research as a group of hypothesis concern three different sub-explanations: 1) in a historical period when economic gains due to the varguismo were not clear, and while the political menace represented by Vargas, the paulistas usually opposed the varguismo during the Estado Novo or at least kept some distance from it. Hence, it ended to be more difficult for the paulistas to form parties or party state sections from the bureaucratic machine as it happened in the rest o the country; 2) when state of São Paulo was already benefited by the industrialism, its politics, however, were marked by the path dependency: usually just politicians not identified with the developmentalism or the varguismo arose in the state - so against the electoral demand of the country; 3) PTB in São Paulo suffered the intervention of varguistas that were afraid of the possible growing of their own party in that state and also faced the political competition of social movements that were prior to the varguismo. Specially the PCB injured the PTB spreading in São Paulo and, when it was considered illegal, the only last force in the state that could be nationalized also disappeared.

Keywords: Paulista politics; 1945 Democracy; São Paulo; Paulista parties; party formation. 


\section{Sumário}

2. Silenciosa, mas a todo vapor. A todo vapor, mas silenciosa

3. Varguismo, Estado Novo e elites paulistas

p.109

4. Formação dos partidos em São Paulo e a democracia de 1945

CONCLUSÃO 


\section{INTRODUÇÃO}

Esta pesquisa tem como objetivo central qualificar o suposto declínio da política paulista em relação à política nacional, depois de 1930 e principalmente na democracia de 1945-64, para então sugerir quais as possíveis causas que levaram a esse resultado. Propõe-se que o próprio significado desse suposto ocaso político dos paulistas não é tão evidente quanto a literatura costuma julgar e, por isso, deve ser especificado: apesar de Vargas ascender em meio a um projeto de re-equilíbrio das forças regionais, contra o predomínio de São Paulo, o varguismo e o posterior desenvolvimentismo ensejaram mudanças sócio-econômicas que beneficiaram diversos interesses paulistas, cujos representantes nunca deixaram de influir nos negócios nacionais. Mesmo assim, é possível identificar como problema central o fato de nem os quadros políticos paulistas conseguirem nacionalizar-se, nem os partidos nacionais ali se consolidarem.

O melhor modo de começar um trabalho para analisar a inserção, o desempenho ou a influência dos políticos paulistas na política nacional durante a democracia de 1945 é, certamente, deixar claro que a economia do estado de São Paulo foi a que mais lucrou com o modelo industrialista que, segundo Bielschowsky (1988), teria emergido do varguismo e formaria um dos pilares do desenvolvimentismo posterior: para Werneck Vianna (1986), a Revolução de 1930 atendia à nova burguesia industrial independendo da participação dela no processo. Para Celso Furtado (2007), na clássica passagem sobre a transição do modelo cafeeiro para um processo de industrialização, é sobre o capital que já circulava em torno do café - e portanto em grande parte dentro das fronteiras e dos interesses paulistas - que se daria a mudança do centro dinâmico da economia nacional.. E não só: é provável que os grandes interesses empresariais paulistas tenham sido todos ou em grande parte atendidos. 
Como veremos, valendo-se da clássica alegoria da locomotiva paulista pode-se dizer que se ela passou a estar politicamente mais silenciosa no período posterior à primeira república do país, continuou economicamente a todo vapor.

Demonstrar e em seguida assumir isso como premissa é importante porque geralmente os interesses econômicos paulistas foram colocados pela literatura como ponto final. Normalmente os analistas tendem a achar que esse resultado econômico é tudo o que importa: derivam dele a suposição de que então a política paulista predominou, atingiu no fim das contas o que seria seu objetivo. Mas como veremos, esses ganhos, antes de provarem algo, recolocam as perguntas. Se alguém se pergunta, neste ponto, qual o interesse em estudar a situação da política paulista vis a vis a política nacional em um período em que os interesses econômicos do estado de São Paulo foram grandes beneficiários, respondo com três princípios norteadores deste trabalho. Primeiro, é preciso deixar claro que elites políticas só são correspondentes ideais de elites econômicas no imaginário do analista. E mesmo a idéia de que uma tem como objetivo direto, mecânico e imediato os interesses da outra, é uma simplificação pouco promissora.

Segundo, é bastante questionável falar em interesses monolíticos "da elite econômica", ou "da elite política", como se existissem tais atores coletivos sem nuances ou divergências internas, como se tivessem uma quase mágica coordenação e desprendimento coletivo de interesses. Em terceiro lugar, toleremos por um segundo esse uso da idéia monolítica. Pode ser até mesmo que do ponto de vista dos resultados finais, as reivindicações "da elite econômica" paulista tenham sido acatadas pelas realizações de governo e pelas deliberações legislativas, ou seja, dentro da política. Mesmo assim, a análise do produto nada falaria sobre o processo: os resultados finais não permitem deduzir o começo e o meio. E em política, frequentemente o processo importa até mais do que o produto. 
Esse tipo de simplificação ex post facto, segundo a qual o que importaria seriam apenas os resultados finais - se São Paulo ganhou ou não economicamente, se "paulistas" tiveram ou não suas demandas atendidas - esquece-se de que o exercício do poder político importa a despeito dos resultados econômicos auferidos. A política relaciona-se com a economia, mas ambas têm interesse por si mesmas. Não é porque a economia do estado de São Paulo em geral tivesse grandes ganhos, que os atores políticos paulistas se contentariam e não almejariam ascender na política nacional e influenciar o mais possível nos rumos políticos da nação. Para o leitor que, por opção intelectual, não julga a política como uma decorrência da economia, isso é um tanto mais trivial. Mas mesmo para aqueles que seguirem, por exemplo, a idéia de Simon Schwartzman (1975) de que São Paulo sofreria um descompasso entre seu desenvolvimento econômico e social e a força política que esse desenvolvimento faria esperar, mesmo para esses leitores não se tornaria ainda mais intrigante desvendar o porquê e o como esse descompasso se estabeleceu? De qualquer perspectiva analítica, então, não se torna questão intrigante vislumbrar por qual motivo os políticos paulistas passaram, em curto espaço de tempo, de uma influência nacional quase monopolística no início do período republicano para um desempenho nacional no mínimo acanhado?

São basicamente consensuais e recorrentes na literatura política as identificações tanto de ampla presença paulista na política nacional durante a República Velha, presença tida como parcialmente hegemônica (KUGELMAS, 1986), como o fato dessa primazia ter entrado em ocaso no período democrático de 1945-64. Não há, entretanto, quase nenhum esforço consistete para qualificar o significado ou compreender as causas dessa mudança de cenário. Assim como havia uma tendência a enxergar uma certa naturalidade na preponderância da política paulista antes de 1930, dadas as desproporcionalidades econômica e demográfica de São Paulo (LOVE, 1982; WIRTH, 1982) ou dada a sua modernidade discrepante (SCHWARTZMAN, 1975), tratou-se também como fato muito elementar que, após o 
intermezzo de um Estado Novo freqüentemente interpretado como movimento reparador da sobre-influência paulista, tais forças políticas de São Paulo declinassem sua participação relativa na política do país (ABRÚCIO, 1998; BARBOZA FILHO, 1995; CARVALHO, 1980; FAUSTO, 1986; entre outros).

Quando menciono que não houve grande atenção à qualificação do significado dessa mudança de cenário, ou por assim dizer, qualificação do significado da queda de influência política dos paulistas sobre a política nacional, trata-se de um quase eufemismo. O problema é até maior do que definir conceitualmente esse significado, ainda que seja de suma importância fazê-lo. É que estou de acordo com Maria do Carmo Campello de Souza, para quem "antes de considerar esta hipótese, convém examinar se a sub-representação de São Paulo no poder político é mesmo um fato, ou um mito" (1977:78).

Fundamentalmente, apenas definindo um conceito e investigando-o é possível afirmar que na democracia de 1945 a política paulista tenha sofrido decadência ou desprestígio do ponto de vista nacional, em relação à República Velha ou mesmo em relação à democracia brasileira atual. E isso, em geral, não foi feito. Nem a questão de qual perda de influência se fala e nem de quais processos específicos a teriam originado, são tão auto-evidentes quanto usualmente se faz imaginar. Está ainda por fazer a tarefa de 1-qualificar o que seria exatamente esse declínio político das forças de São Paulo após o Estado Novo, apontando o que significaria e até onde iria a suposta perda de espaço político na esfera nacional. O que equivale a qualificar o objeto de pesquisa. Para aí sim ser possível investigar o problema central: 2- quais os fatores e os processos que levaram os atores políticos paulistas a, no sentido estabelecido, diminuir sua presença na política nacional após 1930 e especialmente na democracia de 1945-64?

É a busca de respotas para pelo menos parte dessas questões que esta pesquisa se propõe. E exatamente pela natureza um tanto heterodoxa de meu primeiro problema aqui - 
definir se houve e o que era o tal enfraquecimento da política paulista na política nacional - é necessário que a estrutura lógica deste trabalho tenha também alguns passos inusuais. Antes de apresentar uma hipótese, desenvolvo meu trabalho principalmente tentando qualificar o objeto, cuja clareza e precisão teórica não são dadas de barato quer pela pouca literatura que tratou sistematicamente do tema, quer pelo que o conhecimento comum pode dizer sobre o assunto. Motivo pelo qual, também, concentro a coleta de evidências empíricas mais na construção de um objeto de pesquisa do que na comprovação de uma hipótese posterior. Acredito contribuir mais para a literatura fechando o leque semântico de meu objeto de pesquisa - até hoje tão pressuposto, abstraído e rarefeito - do que tendo a pretensão de oferecer uma explicação definitiva para esse fenômeno que é, até aqui, sequer bem descrito.

No primeiro capítulo, tento recuperar as principais linhas analíticas sobre o que teria sido a queda de influência política dos paulistas sobre a política nacional: como diversos autores tangenciaram a questão? Faço uma breve revisão da literatura sobre o assunto e traço algumas relações iniciais e bem gerais com o desenvolvimento histórico da política do país. Com base nessa literatura, no capítulo seguinte investigo propriamente quais afirmações devo ou não aproveitar neste trabalho. Ou seja, investigo e analiso as proposições conhecidas, ainda que estejam subjacentes em textos esparsos que muitas vezes não visavam especificamente avaliar a situação política de São Paulo na democracia de 1945. Rapidamente, aproveito também para delinear a tão citada situação da economia paulista no período estudado. No terceiro capítulo, começo a construir propriamente uma hipótese explicativa para o fenômeno e, no quarto, procuro na literatura mais geral sobre a democracia de 1945 os primeiros indícios que podem sustentar essas minhas sugestões. Antes de começarmos nesse caminho, cabe no entanto resumir e adiantar algumas idéias e alguns ponto des partida básicos que estarão presentes ao longo deste trabalho, a título de introduzir o leitor ao raciocínio e ao problema que pretendo perseguir. 


\section{Pontos de partida}

Na perspectiva do século XX como um todo, diferentes abordagens afirmaram algum protagonismo de São Paulo no Estado nacional, entre as quais: a leitura da singular modernidade paulista em Schwartzman (1975), a questão do fervilhar urbano paulista divergindo do clássico gradualismo imposto via Estado em Werneck Vianna (1997) e a exploração paulista da Questão Regional - desigualdade e divisão regional do trabalho - em Chico de Oliveira (1981). Mas no que se refere a compreensões mais detidas e específicas sobre determinados momentos históricos, o debate sobre o lugar da política de São Paulo na federação brasileira teve início com as análises sobre seu predomínio antes de 1930.

Domínio cujos significados e origens são investigados por autores de relevo como os brasilianistas Joseph Love (1975b, 1982, 1993) e John Wirth (1982), além de Simon Schwartzman (1975) e Eduardo Kugelmas (1986), entre outros. Love e Wirth - esse ao estudar o lugar de Minas Gerais na federação - tratavam a preponderância da política paulista como decorrência natural de seu porte econômico, eleitoral e militar. E Schwartzman, embora acentuando o papel do poder político, via a questão como sócio-economicamente determinada: a preponderância adviria de maior desenvolvimento do sistema econômico, moderno e dominante. É apenas com o trabalho de Eduardo Kugelmas, primeiro também a tratar a questão com exclusividade, que o tema passa a ser visto sem viés de predestinação e sim com a preocupação de demonstrar quais processos e mecanismos efetivamente levaram os paulistas a ditar rumos na política brasileira e a transformar poder social e econômico em poder político. Para ele, a ascensão política paulista no fim do Império estaria relacionada ao fato de terem sido suas elites e seu Partido Republicano as forças que empunharam com vigor a bandeira do federalismo e que construíram a nova ordem que iria ser instaurada - o que é explicado em sua tese por meio de uma bem trabalhada série de processos políticos, históricos e institucionais. 
Essa abordagem de Kugelmas (1986), preocupada com os modi operandi, com os processos pelos quais a política se transforma, abandonando análises apriorísticas ou deterministas sem contudo tratar processos históricos como se história não tivessem, é sem similar no que se refere ao suposto ocaso da política paulista em relação à nacional depois de 1930. Se durante o Estado Novo houve um pacto federativo proibitivo a São Paulo, uma “engenharia institucional” de qualquer tipo (BARBOZA FILHO, 1995), ou um outro processo político específico, é preciso demonstrar, apontar como funciona, como foi erigido. Do mesmo modo que Kugelmas realiza em relação ao outro período, ou que Campello de Souza (1976) faz para o problema da continuidade do Estado Novo sobre o sistema partidário de 1945. Justifica-se esta pesquisa também por sua abordagem, ao perseguir o preenchimento dessa lacuna. Ainda está por fazer, no que se refere à democracia de 1945, o trabalho semelhante de identificar os processos políticos que estariam relacionados à política de São Paulo ficar decrescida de presença na política brasileira. Processos políticos que se encontram no cruzamneto entre a história, as concepções políticas e a formação das instituições.

Pretende-se situar esta pesquisa entre essas abordagens, considerando a importância de ambas as dimensões articuladas pelo conceito de path dependency: primeiramente, no sentido genérico apontado por Pierson (2004), a abordagem proposta leva em conta a importância da história, sem perder de vista os efeitos sincrônicos das instituições políticas. E como discutirei mais tarde, sigo também o sentido específico do termo como Pierson propõe: julgo que os processos de organização das forças políticas paulistas da democracia de 1945 sofreram do efeito de self-reinforcement causado por suas posturas em relação ao varguismo durante o período anterior. Como diz North (1990), as escolhas feitas e as concepções formadas pelos atores políticos não só importam como marcam as instituições e as possibilidades de escolhas e concepções seguintes: ou seja, trajetória e história importam. Nesse sentido, torna-se possível indagar quais continuidades teria o Estado Novo impresso ao sistema político 1945- 
64 a ponto de afetar, ou modificar, o papel da política paulista em relação à nacional. E então: como a realidade política daquela democracia vai (re)trabalhando essas constinuidades iniciais?

Comecemos por esclarecer melhor o que está sendo considerado como ator político paulista. Primeiro, não se trata propriamente de classes sociais, nem mesmo estamentos ou grupos de interesse de matiz propriamente sociológica. Sem dúvida, os interesses são parte fundamental da análise, mas enquanto apareçam sob a forma de vocalização política de alguma natureza: pessoas ou grupos que os manifestam politicamente (diferente da noção de que classes e interesses capturam a priori o Estado). E que o façam pelas vias formais: partidos, candidatos, ocupantes de cargos, burocratas nomeados. Segundo, mesmo para os anos que antecedem a democracia de 1945, não se está considerando as elites sócioeconômicas per se, mas as elites políticas formais - que, como defendi acima, não necessariamente são correspondentes entre si em suas várias dimensões. Estou interessado, pois, nos políticos profissionais no sentido weberiano. E por óbvio, considero políticos paulistas pessoas não que nascem, mas que fazem carreira em São Paulo (porque afinal, é uma terra de imigrantes e migrantes) e representam politicamente interesses sociais e econômicos ali sediados.

No que se refere à República Velha, o predomínio dos paulistas era visto freqüentemente como uma ascendência de poderes sociais e econômicos sobre a esfera política (por exemplo FAUSTO, 1986). Às vezes como junção dessa prevalência com a construção de um arcabouço institucional útil a sua perpetuação, como em Carvalho (1980). Nesse autor e em Abrúcio (1998), há também um peso importante e crescentemente destacado da chamada política dos governadores como instrumento específico daquele período. As atenções se voltavam para questões como: até que ponto as elites sociais de São Paulo teriam conseguido capturar o Estado (FAUSTO, 1986), universalizar a outras classes seus interesses 
(ALMEIDA, 1978), ou até onde os atores políticos paulistas claramente controlariam as orientações do governo central (KUGELMAS, 1986)? Naquela primeira república, um sintoma da sobrepresença paulista antes de 1930 sempre retrarado pela literatura seria o fato de tantos presidentes, vice-presidentes, ministros, grandes nomes da política nacional, terem origem paulista - ainda que Love (1986), por exemplo, paradoxalmente sugerisse não ser vital às elites paulistas controlar cargos e posições no governo para fazer vingar seus interesses.

E depois da Revolução de 1930, o que teria acontecido? A princípio, parece tão temerário presumir que os atores paulistas ficaram à parte dos negócios políticos brasileiros, como sustentar que suas atuações e possibilidades não sofreram alteração alguma quando comparados há apenas 15 anos antes. Em linhas gerais, a idéia básica afirmada pela literatura e a ser investigada é a idéia de que não deixa de ser verdade que a capacidade de São Paulo fazer vingar nacionalmente seus quadros regionais foi diferente. Falando sobre os nordestinos no cenário atual, a definição de Oliveira (1993:44) é excelente ponto de partida se trocarmos Nordeste de hoje por São Paulo de 1945-64: "não há qualquer grande político nacional que tenha construído sua reputação fazendo carreira no NE" ou "não há político algum do NE que consiga alçar-se à condição de liderança nacional”. Essa era a situação paulista na democracia de 1945. É preciso começar, portanto, não considerando apenas interesses econômicos e sociais, mas o próprio jogo político que é onde se dá a mudança: não basta mais interpretar a política através do puro estabelecimento de pontes de influência na captura do Estado, (sentido mais próximo à acepção da teoria das elites, de Mosca, Pareto e Michels, por exemplo), ainda que eles existissem. É preciso incorporar na análise a importância do intermédio das eleições (a inclusão do processo-chave do pluralismo de Dahl). E não é essa uma novidade pequena: sua inclusão faz diferença, porque não seria possível garantir por pura influência no aparelho e na burocracia estatais a presença política de quadros paulistas na esfera nacional. Só seria possível via eleições e quadros nacionalizáveis. 
Analsarei dados eleitorais do período 1945-64, tanto presentes por exemplo em Lavareda (1991) e em Nicolau (2004), como próprios construídos a partir de fonte oficial. E no que se refere a cargos políticos importantes não eletivos, como ministros nacionais, ou definidos não apenas por eleição popular, como presidências de Câmara Federal e do Senado, pretende-se solidificar o argumento contribuindo também para a catalogação de dados políticos, re-analisando o trabalho de Barry Ames (1986) através do banco de dados de nomeações ministeriais e de presidências das casas congressuais entre 1930 e 1964. Pretendo considerar para fins de investigação se a tônica da relação tão específica estabelecida pelos atores políticos de São Paulo com a política nacional foi captada com propriedade por Campello de Souza (1993:29), para quem São Paulo e sua força industrial faziam-se representar melhor nos nichos burocráticos e administrativos do que via partidos e Congresso Nacional - por meio de influência social e econômica, mas nem tanto pela via política formal, uma vez que os paulistas não tiveram sucesso no novo processo que eram as eleições. A locomotiva paulista, se a todo vapor, talvez tenha estado mais discreta. Considerando o ocaso do predomínio paulista como sinônimo de alteração na presença de quadros paulistas na política nacional formal - a despeito da e em paralelo com a influência e com os ganhos exercidos - será que esse ocaso ocorreu de fato? Até que ponto ocorreu? E o que teria levado à diminuição da presença de políticos paulistas no exercício e na disputa da política nacional?

Para perseguir esse objetivo, um dos nortes para antes definir essa diminuição está na proposição de Lima Júnior (1983) de que o sistema partidário brasileiro surgido do fim do Estado Novo e desenvolvido entre 1945 e 1964 consolidava-se em duplo sentido: penetração regional das forças e partidos nacionais e nacionalização das forças e partidos regionais. Minha definição para o "ocaso" dos políticos paulsitas, pretendendo ser mais específica do que as sugestões genéricas oferecidas pela literatura, parte exatamente dessa proposição de Lima Jr., mas negando-a no caso da política paulista: sustentarei, ao contrário, que em São 
Paulo, nem os partidos e quadros nacionais penetraram, nem seus quadros e partidos próprios se nacionalizaram. É evidente, contudo, que esse tipo de afirmação sobre São Paulo não ter penetração das forças políticas nacionais e tampouco não nacionalizar as suas, não pode passar de uma observação interveniente, embora seja um caminho necessário ao argumento. A pergunta que implica é: por que, então, isso ocorreu? Quais as causas desse padrão diverso do restante do país? A hipótese que pretendo começar a construir no fim deste trabalho é a de que as causas desse fenômeno estariam ligadas a três questões relacionadas entre si. Uma delas seria: a) a forte oposição dos principais políticos e partidos de São Paulo ao varguismo, durante o Estado Novo, dificultou que aproveitassem da máquina de Vargas para construção dos novos partidos na mesma intensidade ocorrida em outros estados.

$\mathrm{O}$ argumento é, primeiro, o de que, embora as elites paulistas tenham sido as mais beneficiadas ao longo do desenvolvimentismo e de seu varguismo original, não se sabia no decorrer de boa parte do Estado Novo que esse seria o desfecho do processo (FAUSTO, 2007). Bielschowsky (1988) aponta uma série de dados e análise de materiais primários que apontam nessa direção: é apenas no fim do período e só depois dos burocratas estatais, que setores organizados industriais começariam a esboçar de fato percepção inequívoca dos ganhos obtidos e possíveis no industralismo que se propunha. Os políticos paulistas, inicialmente alijados do constructo estatal de Vargas, tinham mais motivos imediatos para temer o desenrolar daquele processo do que para comemorar os ganhos já em curso. No mínimo, interessava reaver espaços que o centralismo de Vargas tirara das elites regionais, como o de escolherem seus próprios representantes nas regiões (ABRÚCIO, 1998). A oposição ao varguismo é de intensidade variável, mas freqüente, via política (CARVALHO, 1980), via associações do comércio e da indústria (BIELSCHOWSKY, 1988), via imprensa como no caso do Estadão (BENEVIDES, 1981). 
Segundo, proponho que essas posturas dificultaram aos políticos paulistas o uso da máquina de Vargas para montar partidos fortes - no clássico processo descrito por Campello de Souza (1976). Na maioria esmagadora dos estados, o aparato estatal organicista e burocrático das interventorias estaduais foi utilizado como a base para criação dos partidos situacionistas, PSD e Partido Trabalhista Brasileiro (PTB), tendo nascido em desvantagem a oposição, com a União Democrática Nacional (UDN). Vargas nomeava interventores que ao mesmo tempo fossem indicados pelas oligarquias mas tivessem pouca expressão dentro delas, de sorte a terem seus mandatos dependendo apenas da caneta de Getúlio. Em São Paulo não foi diferente e, também ali, os ocupantes da burocracia estadual utilizaram a máquina para seus projetos políticos.

Mas, não para projetos ligados a Vargas: enquanto no resto do país havia uma relação de apoio ou na pior hipótese indiferença para com o Estado de Vargas e seu desenvolvimentismo embrionário, em São Paulo o PSD formou-se através de um aparato burocrata que apenas suportava Getúlio, por falta de melhores opções imediatas. O PSD nasce ali mais fraco, menos coeso, de uma máquina mais rachada. E vê ainda parte importante de seus quadros afluir em direção a Adhemar de Barros, esse sim levando boa parte dos quadros originados no aparato burocrático de quando fora interventor, primeiro para a UDN, depois para o Partido Social Progressista (PSP) que criaria. Esse partido, aliás, desempenha o papel crucial de ser um óbice ao desenvolvimento de PSD e UDN em São Paulo, ao dividir a base de sustentação (SAMPAIO, 1982) um tanto semelhante. O próprio crescimento do PSP dá-se pela aceitação de alternativas ao varguismo, representada na UDN em outros estados, mas apenas em São Paulo originada também da máquina de Vargas. Só em um estado com grande resistência das elites políticas ao apelo do varguismo, mas onde Vargas não poderia dispensar setores amplos da oligarquia local, é que surgiu a curiosa situação de um não-varguismo (difere de anti-varguismo) nascer da máquina de Getúlio. 
A outra ponta da questão estaria no fato de que, b) iniciada a democracia, os políticos de São Paulo não abandonam de imediato a postura anterior, marcados pela trajetória e pelas posturas até então, e tendem a não oferecer quadros muito identificados com o projeto tido como desenvolvimentista-varguista - não oferecendo, pois, produto que era alvo de grande parte da demanda eleitoral nacional.

O legado do momento anterior já se manifestaria no problema da fragmentação dos votos paulistas, demonstrada por Lavareda (1991): o fato de o próprio PSD advir de grupos pouco alinhados ao círculo varguista significava efetivamente uma divisão no seio dos opositores do período 1937-45 entre um grupo com origens na máquina (PSP+PSD) e outro fora dela (UDN). No geral, no restante do país esse grupo estava mais ou menos aglutinado em torno da UDN e de outros partidos pequenos, nunca dividido entre grandes siglas. Mas a ligação mais densa entre os dois momentos, Estado Novo e democracia, parece estar em outro sentido. Havia um projeto desenvolvimentista concebido a partir do varguismo (BIELSCHOWSKY, 1988) que, assumindo figurações diversas, perdura por décadas, tanto no debate econômico quanto na concepção política (LAMOUNIER, 1994). Se o processo perdurava, as leituras e posições em relação a ele modificaram-se: os industriais paulistas se tornavam cada vez mais importantes na política do estado, o que não acontecia antes seja porque durante a maior parte do Estado Novo estavam à sombra das prestigiosas oligarquias cafeeiras (FAUSTO, 1986), seja porque tinham origem estrangeira que ainda dificultava a muitos a política formal (BRESSER-PEREIRA, 1964). Ao mesmo tempo, passavam a se aproveitar mais claramente do industrialismo do modelo e portanto a querer nele influir (BIELSCHOWSKY, 1988). Mas isso não torna automático que as forças políticas quisessem ou conseguissem compor com Vargas: comungam das propostas favoráveis à indústria, mas não estão convictas ou coesas quanto a boa parte do resto do debate econômico (ibidem). E, garantida a penetração de interesses na burocracia que ditava rumos econômicos (SOUZA, 
2006), no jogo político nacional tendem a oferecer apenas opções fortes anti-varguistas (UDN e às vezes PSD) ou não-varguistas (PSP), não contando com próceres de Vargas em São Paulo, como se irá demonstrar através dos dados eleitorais do TSE (1983), alguns presentes em Nicolau (2004). Ao mesmo tempo, a demanda eleitoral nacional em geral inclinou-se, de 1945 a 1964, pela afinidade a Vargas ou aos modelos que esse imaginário posterizou (LAMOUNIER, 1994) - o que é recorrente nos dados e na literatura sobre o período.

Por fim, esse duplo problema de São Paulo não oferecer à política nacional sua maior demanda e ao mesmo tempo ficar à parte da consolidação dos partidos nacionais, precisa ser amarrado pelo papel não apenas das elites políticas paulistas, mas dos movimentos mais próximos de seus trabalhadores urbanos em ascensão. E aí que a trajetória do Partido Comunista Brasileiro e a relação conturbada dos getulistas com os trabalhistas de São Paulo são fundamentais: c) o Partido Comunista Brasileiro (PCB) era o único partido que já estava organizado de saída sem a máquina getulista, era mais forte em São Paulo e dificultou a consolidação do varguismo entre os trabalhadores paulistas, enfraquecendo o PTB posterior; ao mesmo tempo que a ilegalização destruía a única possibilidade que restara de uma força nacionalizável eleitoralmente vinda de São Paulo. Até agora, é notório não se ter falado sobre o PTB nos dois momentos abordados. Isso se deve ao fato de sua pouca penetração em São Paulo ter-se devido em muito à existência, ali, dos comunistas organizados e já atraindo a tendência de votos da massa trabalhadora paulista (SIMÃO, 1956). Em verdade, seu próprio surgimento está ligado à tentativa de Vargas de competir o voto dos trabalhadores com os comunistas, substituindo esses enquanto líderes da classe operária depois da ilegalidade (BRANDÃO, 1997). A relativa estruturação do PCB em São Paulo e a existência de movimentos sindicais anteriores ao varguismo dificultam a consolidação do PTB nascente. E depois da cassação do registro eleitoral dos comunistas, embora parte dos quadros do PCB e 
de seus votos tenham sido absorvidos pela sigla do trabalhismo getulista, o PTB contudo nunca ascende a grande legenda no estado. Em parte devido ao fato, documentado e declarado em série de entrevistas a Sampaio (1982), de o próprio Vargas ter trabalhado todo tempo para podar o PTB paulista, mantendo-no sob controle e vigilância. Especialmente pelo risco de PTB ser capturado pelo sindicalismo emergente, ao invés de capturá-lo (BENEVIDES, 1989). O temor que Getúlio tinha dos trabalhadores paulistas, únicos que poderiam realmente desencadear movimentações urbanas e operárias de vulto, leva à criação de um PTB para cooptá-los, mas também ao posterior controle do próprio PTB: os interesses da classe operária dependeriam de como varguismo e PTB incorporavam essas demandas às suas (BRANDÃO, 1997).

Dificultada a penetração inicial em São Paulo de um importante partido nacional como o PTB, a trajetória do PCB ao ser ilegalizado contribui sobremaneira para castrar uma das principais possibilidades de quadros nacionalizáveis que restaria a São Paulo em meio ao processo sugerido anteriormente. Impedidos os comunistas, um grande partido organizado e forte em São Paulo, que poderia atender parte da demanda eleitoral nacional, sai de cena. Apesar de os movimentos extra-partidários terem continuado e por vezes procurado siglas como PTB (SOUZA, 1976), a ilegalidade mataria sua força quanto movimento participante da política formal (BRANDÃO, 1997), com conseqüências para o sistema partidário e para a situação dos trabalhadores também na política paulista.

A abordagem proposta à elucidação de tema como o desta pesquisa envolve em grande parte, como se vê, o exercício de revisão bibliográfica. Porquanto quase não haja uma literatura dedicada especificamente à questão em vista, trata-se de buscar rever, entre outras temáticas, questões cruciais como as relacionadas à formação dos partidos brasileiros daquele momento, pensamento político brasileiro, historiografia, a política paulista, etc. Contudo, para demonstrar a hipótese central, que se divide em algumas sub-hipóteses relacionadas entre si, 
será necessário recorrer a determinados materiais empíricos e às análises secundárias feitas por alguns autores sobre outros materiais.

Em diversos momentos, será necessário recorrer a dados eleitorais do período 194564, para comparar eleitorados, resultados eleitorais, fragmentação eleitoral, cadeiras no Congresso, subrepresentação, número de partidos efetivos, entre outras pequenas questões subsidiárias à pesquisa. Essas informações poderão ser encontradas ou levantadas pelos dados que se encontram no geral em Lavareda (1991), Lima Jr. (1983), Nicolau (2004), Sampaio (1982), e especialmente em TSE (1983), além de informações interessantes dispersas em algumas outras obras. E outros ainda, mais antigos, sobre eleitorado na República Velha, constam parcialmente dos trabalhos de Love (1975a, 1975b, 1982, 1993). Recorrer-se-á, também, à listagem de alguns cargos federais, como ministérios e presidências de Câmara Federal e Senado, no sentido de averiguar informações sobre legenda e estado de origem, auxiliando na compreensão da questão regional em pauta. Esses bancos de dados são todos de elaboração própria para esta pesquisa. Suas fontes são informações levantadas junto à Secretaria Geral da Presidência da República e ao Ministério da Casa Civil, trabalhadas junto à obra de referência da Fundação Getúlio Vargas (1984). 


\section{Capítulo 1}

\section{São Paulo e o Brasil na literatura política}

Analistas de política, a imprensa de época, atores políticos e mesmo a literatura acadêmica de Ciências Sociais: muitos defendem há bastante tempo que os paulistas apresentaram, durante boa parte do século XX, um papel político nacional que estaria muito aquém do esperado. Por certo, aquém do que esperavam ao observar a impressionante magnitude da população de São Paulo, a dimensão de seu eleitorado, a estatura do que seria a sua suposta importância história, o alcance de seu desenvolvimento moderno, e sobretudo a proporção de sua economia e de sua produção industrial. Trata-se em geral de manifestações de um mesmo paradigma, que nas palavras de Maria do Carmo Campello de Souza é o pensamento "muitas vezes enunciado por analistas políticos e homens públicos brasileiros [...] de que o poder econômico de São Paulo não encontra correspondência ao nível do poder político".Paradigma bem definido pela autora como a idéia pela qual "em vez de impor um projeto político seu (supondo-se que o tenha), São Paulo estaria, segundo esse pensamento, há várias décadas subordinando-se ao poder político de outros Estados” (1977:78) ${ }^{1}$.

Tão digno de nota esperavam ser o lugar de São Paulo na federação, que para muitos nem mesmo a República Velha teria sido palco de um desempenho nacional dos políticos paulistas à altura das importâncias do estado de São Paulo nas várias dimensões possíveis (LOVE, 1982; SCHWARTZMAN, 1976). Nem mesmo ela que passou à história como a república de extremo domínio do consórcio político entre paulistas e mineiros através da não menos sintomática "política dos governadores". E se nem a "república do café com leite"

\footnotetext{
${ }^{1}$ Apenas eventualmente, e dado o novo contexto democrático-eleitoral inaugurado em 1945, o raciocínio somou a esse aforismo a idéia bem expressa por Maria D’Alva Kinzo de que “qualquer análise que se proponha examinar o papel político de São Paulo há que partir da simples constatação de que este estado detém nada menos do que $22 \%$ da população e $23 \%$ do eleitorado brasileiro" (1990:37).
} 
fazia jus ao poder político que os paulistas deveriam/poderiam exercer na política da nação, o que dizer dos quinze anos de governos de Vargas, iniciados com uma revolução em 1930 cujos objetivos incluiriam nada menos do que destituir São Paulo do que se julgava um quase monopólio sobre os rumos da nação?

Dizia o jornal O Estado de São Paulo que "o advento do getulismo significou para o primeiro Estado da União o fim de uma época de predomínio intermitente" (apud SOUZA, 1977:78). E para Cunha (1963:53-4), seria patente “o sentimento de que a Revolução de 30 fora do Brasil contra São Paulo e, do mesmo modo, que a Revolução de 32 deveria ser redenção de São Paulo contra o domínio dos outros Estados". Mas a “deprivação política" de São Paulo, para usar o termo de Simon Schwartzman (1975), teria continuado também na democracia de 1945, sucessora do Estado Novo de Getúlio Vargas. Na continuação do trecho citado, o editorial do jornal O Estado de São Paulo completa ao final: "o panorama não se alterou [sequer] após a Revolução [de 1964]”. Ou seja, na democracia extinta pelo golpe e mesmo depois, o alcance político de São Paulo teria continuado desfavorecido. De fato, vários autores registraram, no que se refere à democracia de 1945, alguma estranheza com a "pouca" influência política direta dos políticos paulistas na nação, quando comparada com a representada por políticos de outros estados (ABRÚCIO, 1998; CARDOSO, 1978, 1981; HIPPÓLITO, 1985; JAGUARIBE, 1962; KUGELMAS, 1985; LAMOUNIER, 1978; LAVAREDA, 1991; LIMA Jr., 1983; LOVE, 1993; SAMPAIO, 1982; SCHWARTZMAN, 1975; SOUZA, 1977; entre outros).

Mas raras vezes essas referências deixaram de ser apenas pressupostas e muito tangenciais. Isso significa que ao mesmo tempo em que em nossa primeira democracia foi se cristalizando essa pressuposição sobre um papel paulista nunca preenchido na política nacional - pressuposição que chegaria aos intelectuais e cientistas sociais da década de 1970 e 1980 - foi exatamente aí que o lugar de São Paulo na política nacional deixou 
progressivamente de ser estudado. E não é que fosse absurdo, no que se refere àquela democracia, perguntarem-se qual o lugar de São Paulo na federação. Jamais causaram estranheza as tentativas de interpretar a ascendência da política gaúcha sobre o desenvolvimento dos acontecimentos nacionais daquele período (CÁNEPA, 2005), a tentativa de analisar as peculiaridades da secular moderação política em Minas Gerais de que falava John Wirth (1982), ou mesmo a opção por estudar o radicalismo da política carioca no decorrer da democracia de 1945 (LIMA Jr et. al, 1987). E de resto, o tema era latente e rondava a política nacional, como enunciado na lamentação do editorial de lançamento da revista Anhembi - revista em grande parte representante da inteligentsia paulista da época: “Anhembi é o nome que os antigos selvagens e as velhas crônicas dão ao Tietê, num tempo em que não havia regionalismos no Brasil" (ANHEMBI, 1950:capa, grifo meu).

$\mathrm{Na}$ verdade, como já no fim do século XIX a política brasileira inspirava o e aproximava-se do famoso cenário de fragmentação política regional-oligárquica temido por Oliveira Vianna (1952), quanto mais retrocedemos na história da República, aparece mais intenso o problema da relação entre as políticas estaduais e a política do país. Tanto para os observadores políticos de cada uma das épocas, como para a literatura que as estudaram. Foi apenas na passagem para a democracia que a questão passou a, embora constituir tema quente nas rodas políticas, ser cada vez menos lembrada pela academia. Mas é compreensível que no desenrolar do século $\mathrm{XX}$ as Ciências Sociais e a subseqüente Ciência Política tenham progressivamente deixado de tratar a política brasileira sob o ângulo dessas questões. A construção de um Estado nacional centralizado e forte, especialmente durante o Estado Novo varguista, e a concretização de um sistema partidário nacional que substituísse a lógica dos interesses localizados pela dos interesses setoriais e de grupos, ambos igualmente nacionais, foram certamente fatores de significativa "desregionalização" da política brasileira (ver ABRUCIO, 1998; CARVALHO, 1980, SOUZA, 1976). Afinal, se é verdade que a Revolução 
de 1930, a ditadura varguista e a democracia que deixaram como herança não retiraram de cena as oligarquias regionais, dificilmente se pode negar que, em larga medida, trocaram as bases estaduais da política do país por bases nacionais - sejam partidárias ou classes sociais.

Também natural é que a pergunta sobre qual o lugar dos paulistas no sistema político brasileiro, como sugeri, tenha se originado e atingido maior desdobramento nos estudos que se dedicaram à passagem do Império para a República. Afinal, a então inédita ascensão dos paulistas - ascensão econômica, social, militar, demográfica e política - esteve na base dos processos que levaram à dissolução dos regimes imperial e escravocrata. Naturalmente, esse processo de inversão de protagonismo nordestino para sul-sudestino despertou grande interesse em quem se dedicava a interpretar os caminhos percorridos pela política brasileira. $\mathrm{E}$ nessas leituras, geralmente é a ascensão econômica que tinha primazia explicativa nessa evolução: o evidente destaque nacional dos atores políticos de São Paulo durante a República Velha seria uma decorrência do desenvolvimento econômico do café, do capitalismo incipiente de seu mercado menos escravocrata (CARONE, 1988; FAUSTO, 1986; FURTADO, 2007; além de muitos outros).

Decorrência da força econômica que depois vira força social e por último se traduz em papel político. Em geral, o lugar de São Paulo na nação durante o período oligárquico foi visto como o do novo centro dentro da lógica centro-periferia, lugar de hegemon dentro do "federalismo hegemônico" brasileiro de que falava Faoro (1958). Para alguns, poder que explora a periferia (OLIVEIRA, 1981). Para outros, independente de julgamento, poder inevitável dada a importância do café na economia nacional. Para muitos, captura do Estado em sentido que parece muitas vezes próximo ao encontrado em Mosca (1984) e Pareto, como acontece com a célebre afirmação de Celso Furtado (2007) de que os cafeicultores teriam total controle sobre a política econômica do governo federal na República Velha. Mas de qualquer 
modo, sempre o lugar de São Paulo na federação como uma conseqüência quer de seu status econômico, quer de suas condições econômicas materiais concretas.

Entretanto, em relação à República Velha, parece não haver dúvidas de que as elites paulistas efetivamente dirigiram politicamente o país, como sugere o trabalho fundamental de Joseph Love, A locomotiva (1982). Antigas afirmações genéricas sobre "paulistas", "cafeicultores", “oligarquias", etc., ganham nesse livro mais especificidade: como as elites econômicas, culturais e sociais de São Paulo capturaram, aos poucos, espaços importantes da cena política nacional? Quem eram essas pessoas? Tendo como preocupação explícita a formação de São Paulo e sua projeção sobre a nação entre 1889 e 1930, o brasilianista coloca mais ingredientes na receita de projeção paulista sobre o país. Não chega a exatamente abandonar a ascensão econômica como variável explicativa última, mas a relativiza: sua explicação dá conteúdo ao papel da economia ao avançar na busca por processos e desenvolvimentos pelos quais teria sido levada a poder político.

E torna menos dura a causalidade ao adicionar um conjunto de dimensões que inclui o tamanho demográfico e eleitoral de São Paulo, além da força militar ali conseguida em uma época em que o federalismo permitia até mesmo aparatos militares estaduais. Como observa Kugelmas (1986, 1985:30), “somente os grandes estados - São Paulo, Minas e Rio Grande do Sul - tiveram condições políticas e econômicas para fazer pleno uso das possibilidades de atuação oferecidas pela Constituição de 1891”. E segundo Love, São Paulo não fez somente pleno uso delas como chegou a ser o caso único de estado financeiramente independente em relação à união, além de ser a origem de enorme parte das receitas do país. Ao mesmo tempo, sua economia pujante permitia desde cedo a manutenção de conjuntos poderosos de forças armadas. Por fim, a população paulista, e por isso no médio prazo também seus eleitores, caminhavam céleres para ultrapassar os mineiros e tornarem-se os maiores do país, feito atingido em meados da década de 1930. Por isso, São Paulo seria ao mesmo tempo mais 
independente e mais imprescindível em relação ao Brasil do que outros estados ou regiões. Esse era o desenho principal de sua projeção nacional.

O estudo de elites políticas que Love, Wirth (1982) e Levine (1988) realizam sobre estados brasileiros na federação é similar nesses aspectos. Em Wirth e Levine, apesar de estudarem respectivamente Minas e Pernambuco na federação brasileira anterior ao golpe de 1937, é possível encontrar o complemento lógico para a explicação do predomínio paulista. É como se essa trilogia de autores descrevesse uma redistribuição de papéis dos estados brasileiros, causada sim por rearranjos produtivos, econômicos, mas também pelas implicações da nova realidade e inserção brasileira no cenário internacional. Causada pela redistribuição populacional interna, pela imigração. Suas perspectivas de investigação das elites estaduais e da inserção delas na federação têm um caráter exploratório que ajuda a suavizar o determinismo econômico clássico. Negando por exemplo a citada explicação de Furtado (2007), diz Love que aquele tipo de tese "não dá a devida importância ao fato de que o executivo [nacional] enfrentava problemas que, em várias ocasiões, provocaram conflitos diretos entre o governo e os interesses cafeeiros" (1982:250).

O interessante nisso é que muitos trabalhos importantes procuraram compreender tanto a formação da economia paulista (por exemplo CANO, 1977; CARONE, 2001; DEAN, 1971) como o funcionamento do regime anterior a 1930 ou as características da presença de São Paulo na federação (CARONE, 1988; CARVALHO, 1980; FAUSTO, 1986; LEAL, 1948). Mas em geral poucos buscaram explicar como e porque os políticos de São Paulo passaram em um momento determinado a possuir papel de destaque na política do país. Se isso é uma decorrência do fortalecimento econômico das elites paulistas, ainda assim seria preciso saber quais processos políticos específicos possibilitaram a influência sobre os negócios da nação.

As características macro-sociais e econômicas do estado e do país naquela época são vitais para compreender a questão, mas não são suficientes uma vez que em geral se 
mantiveram as mesmas antes, durante e depois da República oligárquica liderada pelos paulistas. Cabe importar para esse debate as palavras que Wanderley Guilherme dos Santos usou para rebater as clássicas explicações para o golpe de 1964, puramente baseadas nos aspectos macro-sociais brasileiros: "precisamente por serem macro e seculares, tais processos não podem ser tomados como suficientes para a compreensão de uma crise específica em um momento específico" (1986:17). E daí afirma que "esses mesmos parâmetros poderiam ser usados para explicar [outros momentos e episódios]”.

Ou seja, o cenário descrito pela ascensão do café, das elites paulistas primeiro oligárquicas e depois industriais, é um retrato preciso do contexto. Mas como teria sido transformado em predomínio político é tema que nenhum desses autores abordou de fato. Love (1982), por exemplo, se em seu trabalho combate o simplismo e a unidimensionalidade do determinismo econômico clássico, ainda não emancipa a política da causalidade sócioeconômica. É apenas com o trabalho de Eduardo Kugelmas (1986) que o tema passa a ser abordado sem viés de predestinação, ou seja: nada garantia às forças políticas paulistas que, por advirem do estado com as mais robustas forças econômicas, teriam ipso facto espaço privilegiado no nível nacional. E mesmo que as elites políticas porventura fossem as mesmas que as econômicas, nada garantiria seu predomínio a priori.

Seguindo e completando uma linha pioneira de trabalhos como os de Paula Beiguelman (1967) e Maria do Carmo Campello de Souza (1976), para Kugemas o importante é identificar processos e o modus operandi político que permitem a atores sociais e econômicos consumarem conseqüências políticas. Maria Hermínia Tavares de Almeida assim interpreta o esforço de Kugelmas: "[ele] põe ênfase nos interesses e no processo político que, finalmente, deram vida ao ideal federalista, materializado nas instituições da República”, já que as elites paulistas "se movem, segundo o autor, não por um projeto nacional de hegemonia, mas pelo objetivo de assegurar" seus interesses no estado (2001:15). 
Kugelmas, portanto, tenta demonstrar os mecanismos que efetivamente levaram os paulistas a ditar rumos na política brasileira e a transformar poder social e econômico em poder político na passagem para a República Velha: a ascensão política paulista teria sido uma construção difícil, não um passo inevitável, mecânico. E, pode-se inferir de seu texto, poderia ter dado errado - como sói acontecer a qualquer construção. Parece que para Kugelmas teria sido uma possibilidade ensejada pelo contexto social e econômico, ou seja, estaria no campo do possível e não no campo do necessário, do inexorável. O que talvez, pudéssemos dizer, retira a política de qualquer determinismo e a coloca no campo de uma espécie de possibilismo ${ }^{2}$, no campo das opções possíveis dentro de cada situação histórica, social e econômica.

Assim, o grande peso nacional dos atores políticos de São Paulo durante a República Velha teria sido uma construção política que estaria relacionada primeiro ao fato de as elites paulistas e seu Partido Republicano terem sido as forças que empunharam com maior vigor no fim do Império a bandeira do federalismo e que construíram a nova ordem que iria ser instaurada. Segundo, relacionada ao fato de que isso só teria sido possível dada a unidade dessas elites em torno desse projeto, que se desdobrou na inicial força única do Partido Republicano. A princípio não seria possível sequer afirmar que a suposta hegemonia de São Paulo sobre a política nacional era o objetivo concreto almejado pelos paulistas. Pelo contrário, para Kugelmas, a luta de boa parte desses políticos na época da derrubada do Império visaria na verdade predominar no próprio estado e garantir a possibilidade de controlá-lo politicamente sem o jugo do poder nacional. Em outras palavras, era uma luta por alguma forma de federalismo, o que permitiria realizar o potencial de São Paulo, dar vazão à força que estaria sendo represada pela centralização administrativa imperial, permitir que as elites se auto-governassem e tivessem espaço para defender e construir seus interesses.

\footnotetext{
${ }^{2}$ A analogia de conceitos que faço aqui abertamente é ao debate, dentro da Geografia, entre o chamado determinismo geográfico de Ratzel e o possibilismo de La Blache. A passagem da idéia de "variável que causa um efeito" para a idéia de "variável que delimita um leque de possibilidades de efeitos".
} 
Permitir, principalmente, que tivessem controle sobre os recursos que achavam dever caber àquele estado. Para elites econômicas cada vez mais abastadas, mas que sequer podiam governar-se, qualquer federalismo era melhor do que nenhum federalismo. E por isso não é de se estranhar a unidade de projeto político, comumente rara em qualquer sistema. Kugelmas sugere que essa unidade daria impulso político ao poder econômico dos paulistas endinheirados dos mais diversos setores da economia. $O$ interesse comum pela autodeterminação dentro do estado e, para isso, autodeterminação de São Paulo dentro da nação, permitia um concerto político que não dispersava em disputas de grupos a atuação das elites do estado. E a construção maior dessa convergência acabaria sendo o Partido Republicano Paulista (PRP) durante a República Velha, partido praticamente único em São Paulo, que além de ter constituído ele próprio um dos principais movimentos republicanos do país, foi a origem exclusiva de todas as figuras políticas paulistas proeminentes. O PRP teria tido ainda papel decisivo na passagem de República da Espada para República Oligárquica, com o governo Campos Salles, sendo um dos principais fundadores também do novo sistema político baseado nas oligarquias estaduais. São Paulo possuía, pois, o principal partido da República, as forças políticas nas quais se baseava a construção original e a estabilidade do sistema político. E havia conseguido isso através da rara oportunidade de convergência política em torno da busca das elites por hegemonia dentro do estado.

Como se não bastasse, porquanto os republicanos paulistas não tivessem abertamente comprado a briga anti-escravagista, eram muito menos afetados pelas mudanças que o trabalho livre infligiria nos sistemas produtivos das várias regiões do Brasil. Para Kugelmas (1986), a economia que se ia desenvolvendo em São Paulo colocava-o em posição de estado privilegiado para receber o trabalho livre e, por isso, seria sem dúvida o menos prejudicado pelo fim da escravidão. De um modo e de outro, os paulistas iam tomando à frente as bandeiras que se mostraram vitoriosas na célere queda do Império. Sua relativa independência 
econômica frente ao país permitia-lhes confrontar com pudor muito menor as estruturas políticas que queriam ver modificadas. No fim das contas, os políticos de São Paulo, especialmente seu Partido Republicano Paulista, foram dos principais atores a construir a passagem para a República. E a explicação de Kugelmas (1986) para a ascensão de São Paulo em nível nacional decorre exatamente daí: seus atores políticos tinham estado não apenas ativamente presentes no processo de construção do novo regime, mas tinham até mesmo o protagonizado. Daí decorreria a influência sobre a estrutura institucional que adviria dos primeiros debates sobre como deveria ser o Brasil republicano. A "difícil hegemonia" de que fala Kugelmas é o domínio que as elites paulistas sonhavam ter sobre seu próprio estado, mas cujo caminho para alcançá-lo acabou abrindo espaço para conquistas ainda maiores.

Essa análise de efeitos não intencionais já é por si só uma contribuição inestimável para o debate, porque supera a leitura tipicamente ex post facto de que a suposta captura do Estado pelos paulistas seria a coroação final de uma construção de hegemonia calculada e planejada por atores que tinham ciência plena do futuro. É evidente que a realidade não era assim e que muitos desfechos eram possíveis. No entanto, a opção pela descrição do modus operandi do crescimento político de São Paulo é ainda mais relevante e serve sem dúvida como norte de pesquisa. Esta foi a rara vez em que um autor encontrou uma resposta eminentemente política para a pergunta mais geral sobre o lugar de São Paulo no concerto político do país. E mais especificamente, para a pergunta: de onde veio e como se deu essa prevalência dos atores de São Paulo sobre a política nacional? Resposta baseada em fenômenos, opções e acontecimentos políticos lastreados em dimensões sociais e econômicas, mas não derivados destas.

Essa espécie de raciocínio é sem similar no que se refere ao suposto ocaso da política paulista em relação à nacional no momento posterior, da democracia de 1945. Se durante o Estado Novo houve um pacto federativo proibitivo a São Paulo, uma “engenharia 
institucional" arquitetada com esse objetivo como diz Barboza Filho (1995), ou um outro processo político específico que inverteu a relação dos políticos paulistas com a política

nacional, é preciso demonstrar, apontar como funciona, como foi erigido. Do mesmo modo que Kugelmas realiza em relação ao outro período, ou que Campello de Souza (1976) faz para o problema da continuidade do Estado Novo sobre o sistema partidário de 1945.

As raras sugestões de resposta e as embrionárias interpretações para o lugar da política de São Paulo na federação reiniciada em 1945 infelizmente não seguem esse caminho. Creio que possamos agrupá-las, na verdade, em quatro tipos de abordagem. Semelhantes no diagnóstico sobre o declínio político paulista, mas divergentes em relação às causas desse e em relação à epistemologia mobilizada. Esses grupos de teses apontaram: o descompasso estrutural entre São Paulo e a nação, a captura da burocracia federal pelos paulistas, a desproporcionalidade legislativa e o desenvolvimento dos partidos políticos em São Paulo. Retomo, a seguir, as proposições principais de cada um deles.

\section{Descompasso estrutural entre economia e política}

Durante toda a evolução do capitalismo brasileiro no século XX, os paulistas tiveram seu estado como palco das mais importantes transformações econômicas e sociais do país. A acumulação capitalista pré-industrial do Brasil deu-se ali com o café (FURTADO, 2007), o processo de industrialização foi descolando dos moldes produtivos arcaicos do país (DEAN, 1971). Era ali, então, onde se esperava encontrar o campo social e econômico mais fértil para o desenvolvimento da política moderna, para o desenvolvimento de classes que a literatura sociológica marxista supunha.

Seguindo esses preceitos, aquele estado era o lugar onde, por excelência, era esperado dos partidos políticos correspondência às classes sociais. Nesse sentido, São Paulo não decepcionou os analistas: já em 1956 o artigo de Aziz Simão sugeria pela primeira vez 
indícios de que na capital paulista os votos dos partidos trabalhistas e do partido comunista em 1945 e em 1947 concentraram-se nas zonas operárias e nas industriais. Resultado corroborado, ainda que com ressalvas, pelo estudo precursor de distribuição espacial do voto feito por Oliveiros Silva Ferreira $(1960,1964)$ em relação às eleições de 1958 e 1960 no âmbito estadual. E até mesmo o suporte eleitoral dos ditos populismos de Adhemar de Barros e Jânio Quadros, mostra Francisco Weffort (1965), encontrava vinculação de classe, vinculação sócio-econômica específica.

Esse cenário antagônico ao desenvolvimento que se dava alhures, somado a uma perspectiva teórica cuja explicação da política reside na sociedade ou na economia, foram os pontos de partida que levaram autores a interpretarem o lugar político de São Paulo na democracia de 1945-64 dentro da chave da discrepância entre São Paulo e o Brasil. O livro São Paulo e o Estado Nacional, de Simon Schwartzman (1975), é a única obra que inclui em seu escopo a democracia posterior ao Estado Novo e ao mesmo tempo tem especificamente como objeto central de análise a relação entre São Paulo e o sistema político do país. E sem dúvida foi, nesse assunto, um dos mais importantes estudos que suspeitavam de um certo descompasso estrutural entre a economia (e então a sociedade) que se desenvolvia entre os paulistas e as que estavam em desenvolvimento no resto do Brasil. Para Schwartzman, o modelo paradigmático de urbanização com industrialização gerava naquele estado um processo de modernização discrepante das outras regiões, marcadas que eram no máximo por urbanização carente de industrialização.

Para o autor, a cultura política predominante no Brasil em geral seria a do patrimonialismo: o uso do Estado como patrimônio privado, portanto não como meio mas como fim em si mesmo, como patrimônio a ser explorado. Neles, a política era anterior à mobilização social: a prática da cooptação consistia em levar os grupos de interesse para dentro do Estado, e não em tomar o Estado através desses grupos. Todavia, São Paulo 
começava a dissentir desse padrão. As condições sociais ímpares dadas pela maior complexidade do capitalismo desse estado teriam feito com que apenas ali começasse a se desenvolver um padrão de política representativa (grupos de interesse auto-organizados e lutando por representarem seus objetivos auto-definidos, para influenciar policies), em contrariedade ao padrão cooptativo reinante nos outros estados (poder é atingido não pela busca por representação, mas por cargos burocráticos fixos onde objetivos são atingidos pela prática do favor, para conseguir posições).

Um fazer político que não queria abocanhar o Estado como um patrimônio, mas sim utilizar o Estado para aumentar patrimônio previamente existente: "para os paulistas, a política era uma forma de melhorar seus negócios; para quase todos os outros, a política era seu negócio" (SCHWARTZMAN, 1975:123). Barboza Filho coloca a mesma idéia do seguinte modo: "enquanto o pacto de poder predominante privilegiava o acesso e controle sobre as estruturas e instituições políticas do Estado, os paulistas apostaram numa sociedade comandada por um 'ethos' privado [...]” (1995:94).

O problema, para Schwartzman, estava claramente na relação entre economia e política, colocada pelo autor nos seguintes termos: "quando a atividade econômica independe e prepondera sobre a atividade especificamente política, o sistema de participação política consiste (...) em representação de interesses econômicos", e no entanto "quando é a atividade política que prepondera sobre a atividade econômica (...) consistirá em uma disputa pelo controle do Estado ou pelo acesso a posições governamentais” (p.143). E o domínio desse segundo modelo é que explica, no raciocínio de Schwartzman, o prejuízo que a política paulista vinha sofrendo em sua inserção na política nacional desde mesmo a República Velha.

Sim, pois para o autor nem mesmo naquele sistema o peso paulista poderia ser considerado condizente com sua importância econômica, demográfica e social. A explicação para isso passa ao largo de qualquer questão regionalista e residiria no fato de o sistema 
político brasileiro ter o caminho invertido: não advinha dos interesses econômicos, o que diminuía o peso relativo "esperado" para São Paulo caso o funcionamento político do país seguisse o modelo tido como normal. O que prejudicava a política paulista pelo menos desde a proclamação da República era que a política brasileira não era informada pela economia, pelos grupos de interesse. Se assim fosse, nenhum estado poderia fazer frente aos grupos de São Paulo. Em certo sentido, menos presença paulista era como indício de um Brasil atrasado.

Schwartzman escreveu uma das primeiras obras sobre o período a colocar o Estado como objeto central da análise. E é exatamente por isso que consegue perceber que a suposta debilidade política de São Paulo importava a despeito do sucesso econômico do Estado. Do ponto de vista explicativo, o autor chegou a afirmar, corretamente, que os níveis econômico, social e político seriam analiticamente separáveis: “dizer que esses processos são ‘autônomos’ não significa, evidentemente, afirmar que eles são empiricamente independentes, mas simplesmente que nenhum deles pode ser entendido dedutivamente a partir dos demais" (1975:138). Mas uma coisa é defender essa premissa. Outra é adotá-la de fato. Estritamente em relação a esse ponto, Schwartzman não entrega o que promete. Coloca o Estado como objeto de análise, é verdade, mas ainda o mantém na chave de um certo determinismo. Afinal, seu tipo de pressuposto era a clássica idéia normativa de que apenas o desenvolvimento do capitalismo e de suas forças produtivas levaria ao surgimento de classes sociais per se, classes sociais substantivas. E apenas essas poderiam constituir a base de uma sociedade democrática de verdade. Daí que Schwartzman chegue a ponderar a existência de

somente uma forma de levar o Brasil para um sistema mais aberto de participação política: fomentar o papel de São Paulo na política nacional, ao longo de toda sua estrutura de estratificação sócio-econômica, fazendo com que este sistema regional se expanda até predominar sobre as demais áreas do país, urbanas não-industriais e rurais (p.24) 
É claramente inspirado nesse prognóstico que Barboza Filho, por exemplo, analisa da seguinte maneira o papel do projeto presidencial de Fernando Henrique Cardoso em 1994, presidente que se auto-declarou como encerrador da era Vargas: "esta é uma boa definição inicial da tarefa que o governo Fernando Henrique Cardoso se propôs: a retificação do Brasil de acordo com um modelo de estruturação social e econômica desenvolvido em São Paulo. Ou seja, a paulistanização do Brasil” (1995:118). O grifo, na citação, é de minha autoria: o uso dos termos "retificação" e "paulistanização" denunciam com uma clareza ímpar o ideal de missão civilizadora de São Paulo. Ideal que não estava presente apenas nesses autores, mas em muitos outros - e, suspeito, disseminado para algumas trincheiras externas à academia.

Partindo de premissas similares às de Schwartzman, a similitude da leitura de Werneck Vianna (1997) com esse tipo de raciocínio é patente. Vianna considera que São Paulo não cumpriu o que seria esperado da mais modernizada sociedade brasileira, sugerindo que os paulistas não teriam concretizado seu potencial. Werneck Vianna não estava preocupado em explicar as causas do ocaso político paulista, mas sim em analisar o que significava para o país. A modernidade de São Paulo geraria singulares clivagens de classe, com poder de romper o territorialismo oligárquico e de transpor a manutenção da unidade nacional alcançada então via Estado opressor - uma via que congelava inalteradas as relações sócio-econômicas com a terra. Para ele, a consolidação das classes sociais paulistas seria em si uma promessa (não cumprida) contra o clássico gradualismo imposto via Estado. Aquele gradualismo que faria com que o Brasil, quando muda, nada mude.

São Paulo teria o papel de fazer vencer a modernidade, espraiá-la para prevalecer contra o antigo. Porém, crítico do que de fato se via no desenvolvimento paulista, como os ditos populismos adhemarista e janista que haviam escapado por exemplo ao modelo de Schwartzman, vê que as classes sociais potenciais que São Paulo simbolizaria não estavam sendo concretizadas. E ao deixar de realizar essa missão que salvaria o país do passivismo 
decorrente do territorialismo, São Paulo abdicara de um papel central na política e dera campo ao que outras regiões tinham de mais forte: o arcaico. Essa era a consequiência de um ocaso passivo dos paulistas, mais propriamente modernos do que o resto do país.

É possível encontrar um pequenino texto de Gilberto Freire (1968) em livro pouco conhecido, onde apresenta uma visão sobre a situação de São Paulo em relação ao resto do Brasil que antecipou esse tipo de leitura sobre o papel paulista posteriormente proposta em Schwartzman (1975) e Vianna (1997). Ao passo que o país entrava em acelerado processo de modernização material, cultural, social, simbólica, também para Freire o já avant garde estado de São Paulo era uma espécie de "antecipação, em termos de progresso tecnológico e de desenvolvimento econômico, de uma condição para a qual caminhariam, em ritmos diferentes, outros estados brasileiros" (p.9). E teria o papel de conduzir a modernização da nação. Mas não para ser um civilizador do resto do Brasil, um antídoto contra o arcaico e contra o atraso.

Como historicamente São Paulo havia experimentado a modernização social e econômica muito mais cedo do que o Brasil, teria tido a oportunidade de combinar modernidade com brasilidade, ou melhor, modernidade sem descaracterização do que há de singular no Brasil em prol do que há de compartilhadamente ocidental. E a grande missão que os paulistas teriam era a de impedir que o resto do país, que agora se modernizava, abandonasse suas características tropicais e particulares, deixando de ser propriamente Brasil. São Paulo deveria ser o ponto de partida de uma liderança que construísse um país tropical moderno (p.10):

(...) parece que a missão ampla de São Paulo não é apenas concorrer para que, diminuído o desnível entre sua economia e a dos estados, hoje mais fracos, do Brasil, verifique-se maior integração nacional, com a liderança paulista se afirmando em termos de esforço vigorosamente unificador. Essa liderança talvez deva ir além. Precisam alguns paulistas de superar o mito de não ser São Paulo parte do complexo euro-tropical formado pelo Brasil no seu conjunto (...) S.Paulo precisa de apresentar-se (...) como um líder da civilização euro-tropical - 
particularmente euro-tropical - de que o conjunto brasileiro é expressão cada dia mais considerável.

Desse modo, o papel de São Paulo não é salvar a nação de seu caudilhismo político, ou espraiar desenvolvimento para um Brasil de atrasos. Ou melhor, não se trata de "paulistanizar" o Brasil, mas de "brasilizar" a modernidade. A chave de Freire não recai, coerente com sua obra, na interpretação do país como atrasado, ou da modernidade como panacéia. Centra-se, na verdade, na imagem de um país que possui um curso próprio de desenvolvimento político e, por que não, até de desenvolvimento democrático. O Brasil não é a Europa, e tampouco São Paulo o é. Quando diz que os paulistas são "euro-tropicais" e precisam deixar de achar que não o são, está dizendo apenas que São Paulo não é a Europa dentro do país, e a sociedade paulista não representa a modernidade idealizada.

São Paulo teria a economia mais desenvolvida e o desenvolvimento cultural mais pujante. Mas dentro da euro-tropicalidade geral brasileira, não fora dela. Por certo, seria desejável às outras regiões que elas tivessem seus desenvolvimentos materiais aproximados ao dos paulistas. Só não parece que, para Freire, haja ilações entre esse desenvolvimento que se deseja e qualquer tipo específico de cultura política. O Brasil é euro-tropical; São Paulo também - sendo apenas mais desenvolvido. Especulando, seria ir muito longe interpretar que para o Gilberto Freire desse pequeno texto seria mito os paulistas acharem-se discrepantes quanto à sua cultura política, a despeito de o serem no que tange ao desenvolvimento?

De qualquer modo, a leitura do papel do avanço social e econômico paulista não foi sempre tão generosa quanto nesses autores. Francisco de Oliveira $(1981,1994)$, porquanto enxergue também um desenvolvimento em São Paulo que seguia em ritmo muito mais acelerado do que o do restante do país, é grande crítico do significado desse fenômeno. Via a modernidade do estado de São Paulo na verdade como um símbolo da exploração exercida sobre outras regiões do país. A modernidade paulista não só não seria salvadora, a meta a ser 
atingida ou a origem de onde viria a renovação do resto do Brasil, como seria na verdade a representante máxima da dualidade modernização-exploração tipicamente atrelada ao capitalismo. A modernidade exploradora que atrasa seus explorados. Que realmente insere os explorados no processo de modernização, mas em posições específicas de subalternidade.

A questão regional brasileira ensinava, para Oliveira, que a modernidade que São Paulo estava oferecendo transbordar ao país era a modernidade que interessava aos paulistas: a passagem de outras regiões do status de periferias arcaicas para periferias modernas. Porém, não se trata de oposição a uma leitura como a de Amélia Cohn (1978), para quem a idéia de paulistas travando o desenvolvimento norte-nordestino seria simplista. Se a autora mostra que a criação da Sudene teve amplo apoio de parlamentares paulistas e obste de muitos políticos nordestinos tradicionais, caracterizando o jogo regional de forma muito mais complexa, para Oliveira realmente a relação de São Paulo com o resto da nação não seria de culpa pelo atraso nordestino. A própria criação da Sudene era uma iniciativa importante em sua origem, apesar de sua desvirtuação (ou encampamento pela lógica do sistema) acabar contribuindo para a manutenção inalterada da questão regional (OLIVEIRA,1981).

Na verdade, para ele, o problema estaria no tipo de modernidade ensejada pelo modelo brasileiro, cujo lócus maior e motor principal era o estado de São Paulo. E nesse sentido, Oliveira parece dizer que a modernidade paulista, ao mesmo tempo em que contribuía para tirar o Brasil do atraso, solidificava uma modernidade problemática. A modernização nacional que viria de São Paulo naquele desenho nacional não seria a equiparação do resto do país ao seu patamar. O Brasil não se tornaria moderno do mesmo modo que São Paulo. Não haveria a mítica "paulistanização do Brasil”. A inserção do atual Centro-Oeste, Norte e Nordeste na modernização nacional seria desigual e dependente. Uma vez que a relação estabelecida entre os paulistas e os estados dessas outras regiões seria de exploração típica da lógica centroperiferia, uma das conseqüências sabidas desse tipo de relação desigual deveria ser sempre a 
manutenção da periferia como tal, o que atende aos interesses do centro. São Paulo exploraria a desigualdade regional, a divisão regional do trabalho, criando um círculo vicioso de pobreza e desigualdade que prenderia regiões menos desenvolvidas à distância da economia e da sociedade modernas.

E o pior é que sequer o domínio paulista conseguiria efetivar-se: a não hegemonia paulista no pós-Estado Novo devia-se ao fato de que São Paulo tentava hegemonizar via mercado (OLIVEIRA, 1981; e melhor acabado em 1993). Essa arma de suas elites era frágil, dada a mal resolvida unidade econômica nacional como mero fruto da política. A via do mercado explorador era ainda pouco nacionalizada se comparada à via política em que as oligarquias se assentavam (1993). As forças políticas paulistas estavam em outro patamar, já que assentadas em um estado explorador. E nele davam vazão a seus interesses econômicos mais diretos, de sorte a batalhar com armas inadequadas na arena brasileira. É um outro caminho que leva a uma comparação interessante com a interpretação de Schwartzman (1975): para esse, como vimos, São Paulo tinha desempenho político insatisfatório na democracia de 1945 porque a política brasileira não vocalizava os interesses econômicos tal como deveria. Enquanto para Oliveira, as elites do estado tentavam hegemonizar a política nacional via mercado em um país cujo sistema de mercado era apenas incipiente.

Não se pode negar a importância dessas análises que procuraram entender o suposto alijamento político relativo de São Paulo em relação à política nacional nos termos de uma discrepância dos desenvolvimentos da economia, da sociedade e da representação política entre os paulistas e o Brasil. Especialmente no que tange a tecer um quadro heurístico para a questão sobre o descompasso entre poder econômico e poder político. No entanto, seus pressupostos apresentam problemas. Em primeiro lugar, do ponto de vista mais substantivo, é possível reparar que a idéia de descompasso presume um desenvolvimento paulista descolado do processo político contemporâneo a ele. Dito de outro modo, essa abordagem esquece que a 
conjuntura política em curso durante entre 1930 e 1964 foi a própria origem de boa parte dos fatores de desenvolvimento econômico paulistas. E em segundo, porquanto a dimensão econômica seja parte constitutiva da realidade social em que surge a dimensão política, não se pode derivar essa daquela - como de resto o próprio Schwartzman chamou a atenção.

Julgar que São Paulo teria desenvolvimento político discrepante em relação ao país por causa de seus desenvolvimentos sócio-econômicos anteriores, é claramente discutível. Tanto como afirmar que os paulistas seriam levados a hegemonizar via mercado (OLIVEIRA, 1994). Não creio por exemplo que "tudo leva a crer que, conforme prossiga o desenvolvimento da área intermediária, as zonas mais adiantadas desta ingressem no estágio superior de desenvolvimento e passem a reagir, politicamente, de forma semelhante a São Paulo" (JAGUARIBE, 1962:36-7). Alinho-me à recomendação de Eli Diniz e Renato Boschi: “é necessário se precaver contra o possível reducionismo que pode resultar do pressuposto de uma correspondência necessária entra poder econômico e eficácia política” (1978):26). E em bem da verdade, até mesmo supor que São Paulo tenha tido um modelo tão diferente da nação em termos de representação ideal é questionável, no mínimo, através das figuras de Adhemar de Barros e Jânio Quadros, baluartes do que a literatura convencionou chamar de populismo.

\section{A captura burocrática e a exigüidade de participação política}

A proposta de Oliveira, se é verdade que constitui mais uma representante importante desses trabalhados, é também exemplar relevante para um segundo grupo de leitura para o problema da "deprivação política" paulista durante a democracia de 1945. Afinal, sua teoria conduz à discussão sobre a captura da burocracia federal por parte das elites sociais e econômicas paulistas. Para Oliveira (1994), a tentativa de hegemonizar via mercado, advinda da posição paulista de centro explorador, resultava em um esforço de captura da política 
através dos cargos burocráticos, uma vez que as elites de São Paulo não teriam conseguido efetivar uma completa hegemonia sobre o resto do Brasil.

Uma concepção de mando paulista, um tipo de domínio e um modelo de exploração em que a impossibilidade do julgo político tradicional não impossibilitava ganhos econômicos. Idéia análoga àquela de Love (1982), para quem já na República Velha não era vital às elites paulistas controlar cargos e posições no governo para fazer vingar seus interesses. E idéia que aparece também em Campello de Souza (1994:29), em dois movimentos diferentes de raciocínio: por um lado, $1^{\circ}$ ) oferece o diagnóstico puro de que estados mais industrializados, basicamente São Paulo, faziam-se representar melhor nos nichos burocráticos e administrativos do que através de partidos e do Congresso Nacional. Por outro lado, propõe a idéia analítica $2^{\circ}$ ) de paulistas trocando poder político por comando econômico. Nas palavras de Fernando Abrúcio, sobre o processo de centralização política herdado do Estado Novo pela democracia que surgia: “o processo de constituição do Estado desenvolvimentista teve como arena decisória a burocracia federal e não o Congresso nacional. Criou-se uma estrutura estatal centralizada na qual os interesses econômicos (...) se faziam representar" (1998:49).

Na sugestão de Oliveira (1994), o processo aparece no conceito de "barganha estatista”, retirada de Sallum Jr. e Kugelmas (1993) e colocada nos seguintes termos: “(...) um balanço cuidadosamente estruturado entre a dependência do país das regiões mais industrializadas e costeiras e as demandas do interior e dos setores mais ruralizados por influência política" ${ }^{3}$ (SOUZA, 2006:30). A prova empírica desse modelo seria o artigo de

\footnotetext{
${ }^{3}$ Nesse excerto, é cristalina a influência da idéia clássica do Sul-sudeste progressista contra o Norte-nordeste conservador e retrógrado, nos moldes de Gláucios Soares (1973) e de Celso Furtado (2007). Em outro momento teremos futuramente a oportunidade de discutir um pouco mais detidamente a questão.
} 
Barry Ames (1986), cuja demonstração central residiria no suposto predomínio paulista nos ministérios de relevo econômico. Para Ames ${ }^{4}$ :

"Num certo sentido, São Paulo fez uma barganha: outros estados poderiam ter a parte do leão dos pequenos projetos fisiológicos, mas São Paulo controlaria integralmente a política macroeconômica do governo, assegurando-se de investimentos e de políticas cambiais e fiscais favoráveis. Os paulistas não estavam nem sobre e nem sub-representados nas pastas ministeriais, mas as posições que eles dominavam eram cruciais: Fazenda, Obras Públicas e o Banco do Brasil” (p.198).

De qualquer modo, o grande avanço no modelo interpretativo cujo foco é a captura burocrática é não mais identificar causalidade linear entre os dois lados do enigma (de economia para política), mas sim a qualificação do desenvolvimento sócio-econômico como um ganho. De um lado, paulistas tinham ganhos econômicos. De outro, perdas políticas. Os termos são postos como concomitantes e contemporâneos: fazem parte do mesmo processo, não antecedem ou deduzem um ao outro. E precisamente por isso, nesses termos pode existir política a despeito da economia e do desenvolvimento social.

Mas há uma diferença sutil entre aqueles dois movimentos desse raciocínio da "barganha estatista", que é de extrema importância. Um movimento é diagnóstico $\left(1^{\circ}\right)$, outro é proposta de explicação desse diagnóstico $\left(2^{\circ}\right)$. Ou seja, uma opção é enxergar a tal barganha estatista como um mero diagnóstico: ela seria indicadora de que de fato as genéricas elites paulistas tiveram uma relação diferente com o sistema político durante a democracia de 1945. Ela é que precisaria portanto ser explicada. O problema é que a literatura geralmente não acha que a "barganha estatista" é apenas proxy da situação da política paulista, mas sim a explica. Aí passa a ser mais problemático.

O que quero dizer é o seguinte: essa idéia de troca planejada e proposital acaba supondo que o importante para a elite social de São Paulo era um dos lados, o dos ganhos

\footnotetext{
${ }^{4} \mathrm{O}$ curioso é que esse trabalho empírico seminal de Ames (1986) quase não apresenta dados empíricos. Na verdade, nem os números e taxas de ocupação dos ministérios são publicados. Pretendo retomar esse debate mais à frente, sanando essa ausência de dados.
} 
finais materiais, viessem como viessem. Em princípio, o pressuposto lembra um dos temas políticos centrais para Marx em seu 18 Brumário de Luís Bonaparte (1968): a idéia de que o exercício de dominação por via política só importa até o ponto em que os interesses privados ou de classe sejam ameaçados. Ora, certamente a política nacional era para qualquer ator social ou político paulista um meio para realização de preferências individuais, tal como descreveria a democracia formal de Schumpeter (1961).

Mas isso não significa que a política não seja em si mesma uma das preferências, ou seja, que a política não possa importar por si só. Há dois problemas centrais da literatura (ou dos entusiastas do modelo) que se inspirou mais ou menos diretamente na idéia de que os paulistas abriram mão de poder político em troca de ganhos econômicos. Não se detalha melhor o porquê dessa decisão e não se especifica quem é que a toma. Afinal de contas, para qualquer ator social brasileiro dado, assim como na França descrita por Marx, não seria melhor ainda poder preponderar politicamente caso houvesse essa opção, além de apenas garantir os ganhos econômicos? Parece evidente que sim.

Mesmo na chave analítica da captura feita através do corporativismo que antecipa o empresariado, tal como se pode apreender de Edson Nunes (1999), esse ganho econômico a despeito da política pode descrever os termos em que se deu a dissociação entre economia e política em São Paulo. Mas não explica porque aconteceu. Abrúcio (1998:46-7), por exemplo, afirma: "diante do emergente setor empresarial, particularmente o paulista, o modelo corporativo da representação de interesses foi utilizado, canalizando as demandas empresariais para a arena burocrática”. Mesmo que aceita sem contenda, esse tipo de afirmação só explicaria como a genérica elite econômica paulista fez valer seus interesses. Nada diz ou diria sobre porque chegou a ser necessário utilizar a via arena burocrática e não a política usual. Nada intui sobre como essa elite econômica, ou a elite política, ou quem quer que se queira, teve influência política formal debilitada ao ponto de precisar da via alternativa. 
Como afirmei anteriormente, essa é a pergunta de meu interesse - e não refutar ou comprovar que paulistas genéricos fizeram valer seus interesses por este ou aquele meio.

Do ponto de vista analítico, há então uma série de hipóteses plausíveis para o descompasso entre o poder político e o poder econômico atingidos pelos paulistas na democracia passada. Primeiro, não se pode excluir a possibilidade de os ganhos econômicos para São Paulo terem sido incidentais e nada terem a ver com a perda de poder político em si mesma. Segunda possibilidade: muitas vezes se toma de modo sutilmente implícito que tenha havido uma troca proposital e conscientemente antecipada. Mas na prática, isso parece muito implausível, porque seria preciso que entidades vagamente genéricas como "a elite" tomassem a decisão pela barganha estatista. Seria necessário que todos os membros desse grupo - social, econômico ou político, tanto faz para o presente argumento - ou grande parte deles estivessem de acordo, não se dividissem ou estivessem monoliticamente do mesmo lado do jogo. Mas estariam?

Em terceira opção, pode ser que os ganhos econômicos dos paulistas tenham tido o efeito de limite do que seria menos custoso do que se rebelar contra o novo status quo criado: para os atores políticos de São Paulo, como para qualquer ator político, a preferência óbvia é por deter poder político e assim maximizar seus interesses. Não podendo isso, até que ponto toleravam perda sistemática do jogo político? Até o ponto em que custos da derrota na democracia sejam menores do que os de confrontar o sistema, como apontou Przeworski (1991). Mas o próprio autor adensou posteriormente (2005) essa sua idéia original:

[I] argued that democracy is sustained when the losers in a particular round of the electoral competition have sufficient chances to win in the future to make it attractive for them to wait rather than to rebel against the current electoral defeat. The argument was that when the value of electoral victory is greater than the expected value of dictatorship which, in turn, is greater than the value of electoral defeat, then political actors will accept a temporary electoral defeat if they have reasonable prospects to win in the future. In light of the model developed here, such prospects are neither sufficient nor necessary for democracy to survive. In poor 
countries, they may be insufficient. Above some income level, in turn, losers accept an electoral defeat even when they have no chance to win in the future, simply because even permanent losers have too much to risk in turning against democracy. Political forces are 'deradicalized' because they are 'bourgeosified' (PRZEWORSKI, 2005:266-7).

Portanto, se ganhos de São Paulo não foram em troca de perda política, podem ter sido o que fazia os paulistas resignarem-se a esse fenômeno que certamente não preferiam. Esse é o sentido da idéia de barganha que Campello de Souza parece concluir em outro artigo:

\footnotetext{
a mudança decisiva e que tantos ressentimentos causou entre alguns, talvez entre a maioria, foi a alteração na forma dessa influência, ou, mais exatamente, a redução de um controle quase monopólico a uma influência entre outras. Em lugar do controle direto que antes detinha sobre os órgãos mais importantes, a elite paulista teve de submeter-se à participação em conselhos, autarquias, institutos, enfim em todo o emaranhado da burocracia econômica federal que se começa a desenhar nos anos trinta $(1977: 79)$
}

No entanto, se é verdade que essa versão da idéia passa a fazer sentido, sendo aceitável, parece-me que mesmo assim apenas só repõem o problema: por que motivos paulistas precisaram chegar a aceitar um mal menor? Ou seja, desse quadro, o que mais nos importa neste momento é reparar que, praticamente em qualquer das opções, a idéia da barganha estatista não esclarece o porquê do não domínio político ou os mecanismos desse ocaso. Felizmente podemos guardar sua contribuição sobre os ganhos econômicos para aprofundá-la mais adiante, enquanto buscamos alguma luz no que se refere à dimensão da deprivação política de São Paulo nos moldes de Kugelmas (1986) e Campello (1976), que orientam este trabalho. E efetivamente, os outros dois grupos explicativos que ainda não consideramos centram suas atenções especificamente no desenvolvimento dos processos políticos da redemocratização na débâcle do Estado Novo. São elas as idéias centradas na sub-representação legislativa e no desenvolvimento do sistema partidário em São Paulo. Vejamos. 


\section{Inserção política dos paulistas afetada por mudanças na política nacional}

Ainda que sejam bastante difusas, é possível encontrar na literatura política um conjunto de percepções que relaciona a queda de influência paulista na política nacional após 1930 com mudanças ocorridas na própria política nacional. O tipo recorrente de interpretação política indica como responsáveis, indiretamente ou de modo pouco detido: a passagem do varguismo supostamente anti-paulista, a Revolução de 1930, o Estado Novo, a ascendência do círculo gaúcho em torno de Vargas. Essas sugestões são pouco claras, semeadas e dispersas em muitos autores e em boa parte do senso comum sobre o período. Constituem, parece, quase que uma ideologia poderosa sobre o varguismo frequentemente compradas sem maiores ressalvas ou exigências.

Volto a citar Barboza Filho (1995) como um dos textos mais explícitos, ainda que apenas represente uma impressão difusa muito maior. O autor sugere que São Paulo teria sofrido prejuízo de uma engenharia institucional, política ou de nomeações, ou mesmo um “pacto federativo da era Vargas" que "proibia a São Paulo a possibilidade de domínio sobre a dimensão da política no plano nacional" (1995:118). Contudo, a intuição intrigante não passa a argumento convincente: geralmente não se menciona qual seria esse pacto, essa engenharia, os processos envolvidos, como isso se deu. É preciso mostrar qual é essa engenharia de que fala Barboza Filho e que cola no subconsciente de qualquer estudante de segundo grau ao

aprender sobre o Estado Novo. É preciso mostra-la, se é que existiu de fato. É preciso investigar por quais meios Vargas ou o varguismo teriam prejudicado politicamente os atores de São Paulo, já que economicamente lhes proporcionam ganhos vultosos (FAUSTO, 1986; OLIVEIRA, 1981; VIANNA, 1986).

Um pista é dada por Eduardo Kugelmas (1985:31), quando recorda que "praticamente todos os analistas ressaltam o caráter centralizador da Revolução de 1930: a expansão do 
Estado nacional, que amplia e diversifica enormemente seu campo de intervenção". Uma centralização que, para Eli Diniz (1989:81), encetou o "fortalecimento do poder de Estado [que] agiria como poderoso instrumento de subordinação dos interesses restritos, regionais e locais”, sendo que “a supremacia do 'interesse público' sobre o 'interesse privado', do 'poder público' sobre o 'poder privado', se reduziria em parte a uma questão de eliminação do excesso de federalismo da Constituição de 1891”. Ainda dentro dessa perspectiva de antiregionalismo havia o objetivo não disfarçado de obstar o que seria um sobre-poder dos políticos paulistas. A imbricação das duas dimensões - desregionalização da política do país e confronto ao domínio político paulista - foi bem desenhada por Bolívar Lamounier (1994:29): no primeiro momento, a Revolução de 1930 foi essencialmente uma recentralização do poder, portanto uma reconstrução do Estado, no sentido estrito da fixação, pela violência, de uma nova soberania. Essa realidade primária, retratada nos cavalos gaúchos apascentados ao pé do obelisco do Rio de Janeiro, foi ratificada dois anos depois, na vitória militar sobre o movimento constitucionalista deflagrado em São Paulo".

Fernando Abrúcio (1998) aborda muito bem a questão: “o legado varguista [trouxe] uma importante conseqüência: o fortalecimento do eixo nacional do sistema político" e “embora o crescimento econômico continuasse sendo concentrado no Sudeste, particularmente em São Paulo, alguns fatores aumentaram a multipolaridade do sistema [federativo]" (p.50). Um deles eram as Forças Armadas, expandidas e nacionalizadas tal como Stepan $^{5}$ (1975) e Carvalho (1980) também salientaram ter sido característico daquela democracia, em contraponto ao cenário de forças e milícias estaduais na República Velha (LOVE, 1982). Havia ainda a ideologia nacionalista como norte do debate político, comprovada pelo impacto sobre setores tão diversos quanto os que compunham a ESG e o ISEB (ABRÚCIO, 1998:49-50). Sem contar que Vargas tanto usava a representação classista

\footnotetext{
${ }^{5}$ Para quem os militares brasileiros passariam inclusive a atuar como o papel de Poder Moderador da democracia de 1945.
} 
proposta para o pleito de 1937 no intuito claro de substituir clivagens regionalizadas por classes nacionalizadas, como optara ele próprio na hora da democratização por forçar via legislação a formação de partidos nacionais (OLIVEIRA, 1973:17) ${ }^{6}$.

Mas há outras transformações ainda mais importantes. Mudanças centrais no sentido proposto por Chhibber e Kollman (2004) para outros países: um dos mais fortes incentivos à nacionalização das forças políticas não estaria nas instituições, mas nas atribuições políticas dadas ao poder central. Dito de outro modo: poder central fortalecido nacionaliza a política porque incentiva os partidos e os grupos de pressão a atuarem em busca do âmbito nacional. Nesse sentido, o Brasil viveu, sob o interregno varguista, aquilo que Eli Diniz (1989:79) descreve como "esforço de centralização político-administrativa, pelo qual se mantém a autonomia do Estado": criação de interventorias nomeadas pelo governo nacional para governas os estados; autarquias, institutos e conselhos para decidir sobre uma gama crescente de temas de política econômica e social (idem); daspinhos - que eram corpos técnicos em substituição aos legislativos estaduais (ABRÚCIO, 1998; SOUZA, 1976). Por consequiência dessa série de elementos de centralização e fortalecimento do poder da União, segundo Abrúcio,

\begin{abstract}
"as relações federativas se tornaram mais equilibradas. Os estados recuperaram sua autonomia e a União, mediante o arranjo varguista, aumentou seu raio de ação. A União aumentou muito o seu poder da Primeira para a Segunda República e os dois grandes estados do período do "café-com-leite", Minas e notadamente São Paulo, perderam, em termos relativos, força" (1998:50).
\end{abstract}

Esse ponto é definitivamente central. Afinal, ao menos esse importante declínio político dos representantes de São Paulo em relação à política nacional ocorreu: uma perda relativa de poder. Ou seja, a política de São Paulo declinou, em parte, simplesmente porque o

\footnotetext{
${ }^{6}$ Olavo Brasil de Lima Jr. (1983) discorda desse reforço ao surgimento de partidos nacionais. Chama a atenção para o fato de que, por outro lado, os obstáculos reais à formação de incentivos regionais eram muito tênues. Do ponto de vista institucional, houve incentivos a que dois ou três começassem grandes, mas não que apenas surgissem grandes legendas.
} 
poder central da União aumentou. Qualquer política regional passou a ter espaço bastante menor de poder em relação à política nacional porque os próprios espaços foram diminuídos.

Só isso já garantiria, do ponto de vista institucional, que a correlação de forças inter-estadual fosse, politicamente diversa da que existia durante a República Velha. Mas esse fenômeno precisa ser analiticamente distinguido do que seria a posição política dos paulistas pari passo com as dos atores de outros estados da federação.

Dito de outro modo, por um lado as mudanças ensejadas pelo Estado Novo foram capazes de fortalecer a União e com isso diminuir os espaços para predomínios estaduais, no que São Paulo é o maior perdedor relativo. Mas por outro, isso não explica o motivo pelo qual mesmo assim políticos paulistas teriam tido participação menos destacada na política nacional do que estados como Minas Gerais, Rio Grande do Sul, Rio de Janeiro, Bahia. Uma coisa é entender porque São Paulo não podia mais dominar politicamente como antes de 1930 - o que tem a ver com a centralização do poder político em nível nacional. Outra é entender porque os políticos paulistas passaram ser menos visíveis na política nacional do que os de outros estados, como sugerido pelas diversas abordagens até aqui.

\section{A formação dos partidos políticos em São Paulo}

Por certo, o fenômeno político que passou a ser mais frequentemente identificado com a inesperada e suposta sub-influência da política paulista foi a não consolidação, em São Paulo, dos partidos políticos que se tornaram nacionalmente fortes na democracia de 1945 . O desempenho político dos partidos em uma democracia, como se sabe, depende entre outros fatores de sua organização, penetração e estrutura. E não foram poucos os autores que apontaram, por diversas abordagens, que durante a democracia de 1945-64 os principais partidos brasileiros não conseguiram se estabelecer eficazmente em São Paulo (BENEVIDES, 1981, 1989; CARDOSO, 1981; HIPPÓLITO, 1985; KUGELMAS, 1985; LAMOUNIER, 
1978; SAMPAIO, 1982; SCHWARTZMAN, 1975; SOUZA, 1976; entre outros). Enquanto as forças políticas paulistas surgiam paralelamente, como nos ditos populismos de Adhemar de Barros e Jânio Quadros.

Implicitamente, diga-se de passagem, esse diagnóstico da "atipicidade" dos partidos paulista (KUGELMAS, 1985:33) muitas vezes contradisse a idéia clássica da discrepância entre o São Paulo moderno e o Brasil atrasado. Ao contrário, se é verdade indiscutível que os paulistas possuíam a economia mais pujante e mais moderna do país, não era tão óbvio que daí se derivassem as relações políticas ou a cultura política mais modernas. Em seu artigo, ainda que Maria do Carmo Campello de Souza classifique o fragilizado sistema de partidos paulistas como uma "anomalia", comenta:

mesmo aceitando a tese segundo a qual São Paulo possui maior tradição democrático-representativa, salta aos olhos que não a possui no que diz respeito à tradição brasileira de vida político-partidária. Ao contrário: no período de 1945 a 1964, São Paulo, o grande centro econômico e industrial do país, notabilizou-se precisamente pela fragilidade de suas seções nos três principais partidos nacionais $[\ldots] "(1977: 78)$.

Já autores como Bolívar Lamounier (1978) são até mais incisivos, ao sugerirem que outros estados brasileiros possuíam desenvolvimento das relações políticas e das identidades partidárias bastante mais avançado que São Paulo:

para alguns, as suposições apontadas, em particular a desvinculação entre posição sócio-econômica e afiliação política, fossem ou não adequadas para outros estados e regiões, não eram descabidas em relação a São Paulo, tendo em vista certos aspectos singulares da evolução político-partidária desse estado, em comparação com o Rio Grande do Sul ou com o Rio de Janeiro, onde os partidos de dimensão efetivamente nacional tinham raízes mais fortes e comandavam alentados contingentes eleitorais. Em São Paulo, precisamente no estado econômico e industrialmente mais avançado, o sistema partidário pra-1964 expunha sua fragilidade" (p:18). 
É sem dúvida interessante ver essa relativização da idéia de que São Paulo oferecia as mais evoluídas ${ }^{7}$ práticas políticas e por isso era, ele mesmo, um estranho em sua própria terra, para lembrarmos a imagem de Sérgio Buarque de Holanda (1973). Mas o mais interessante nessa vertente - que ensaiou diagnosticar a situação política dos paulistas na democracia de 1945 como vinculada à situação por que passaram os partidos políticos naquele estado - é que, diferentemente das outras leituras que se fez, ela não fala em prejuízo político de São Paulo, alijamento dos atores paulistas ou algo do gênero. Seu diagnóstico é bem mais específico e portanto o problema de análise com que lida é claramente delineado: a fraqueza dos partidos nacionais em São Paulo, a não penetração dessas legendas. Enquanto em geral o que encontramos até aqui foi uma certa frouxidão na qualificação do que seria a genérica e nublada "deprivação política", nesse caso não há abstração sobre o que significava declínio político de São Paulo.

Para qualquer dos autores comentados anteriormente, a pergunta necessária seria: o que significa queda na influência política dos paulistas, ocaso da presença da política paulista na nacional, deprivação? Esse fenômeno constitui certamente o típico caso em que pode ser fácil visualizar e até concordar, mas é difícil definir. Basicamente, nenhum autor definiu o que deveria ser uma política paulista condizente com o desenvolvimento econômico do estado de São Paulo. Qual o ponto em que nos daríamos por satisfeitos? Qual o critério? Tampouco há qualquer clareza sobre o que significaria a política paulista não ter sido, por hipótese, levada à "barganha estatista". O que teria de ter ocorrido para não enxergamos essa barganha? Ou seja, nesse assunto costuma-se tratar como evidente e como ponto pacífico algo que não o é necessariamente. Políticos paulistas menos influentes na política nacional significa o quê? Partidos fracos? Mal desempenho eleitoral? Fraca atuação legislativa? Poucos cargos políticos para um estado tão grande quanto São Paulo?

\footnotetext{
${ }^{7}$ A palavra acusa o sentido evolucionista da idéia não por mera coincidência de linguagem.
} 
O diagnóstico do pouco desenvolvimento dos grandes partidos nacionais em São Paulo foi assim colocado por Campello de Souza, em prefácio ao livro de Regina Sampaio (1982:14): “a singularidade de São Paulo no quadro político-partidário nacional tem sido apontada com certa freqüência, mas pouco se fez para delineá-la de maneira precisa”. De fato, são escassas as tentativas de explicar as causas desse diagnóstico de fraqueza dos grandes partidos em São Paulo. Até porque, na evolução das Ciências Sociais no Brasil, não foi longo o interregno entre a promoção do sistema partidário ao status de objeto de análise relevante e o abandono das clivagens regionais.

Antes, contudo, de proceder às discussões mais substantivas sobre o tema da debilidade política dos partidos em São Paulo durante nossa primeira democracia, vale introduzirmo-nos na discussão lembrando uma ressalva en passant da própria Campello de Souza:

\footnotetext{
Desde logo, podemos lembrar que a anemia partidária de São Paulo se deve pelo menos em parte a acontecimentos quase fortuitos, como o prematuro desaparecimento de algumas lideranças. É o caso por exemplo, de Fernando Costa, a quem seguramente teria cabido o papel de contrapeso a Benedito Valadares no PSD. Morto aquele, Minas e Benedito deram a esse partido sua feição definitiva, a partir da arregimentação dos interventores e prefeitos, no momento em que o Estado Novo começava a decompor-se. O mesmo se pode dizer, mutatis mutandis, do desaparecimento de Armando de Salles Oliveira em relação à UDN (1977:79)
}

Realmente, ao discorrermos sobre o assunto, não se pode perder esses fatos fortuitos de vista. Talvez até mais no caso de Armando Salles. Evidentemente, a morte de lideranças dessa envergadura alterou a competitividade de grupos políticos que os cercavam e dificultaram o desenvolvimento de setores da política paulista. Não incorre nenhum absurdo em admitirmos isso de antemão. No entanto, como a autora mesma comenta, esse tipo de explicação serve-nos, na melhor das hipóteses, “em parte”. Ajuda a entender uma ou outra fraqueza, mas por óbvio não pode nos indicar padrões políticos gerais, explicar recorrências e 
definir a situação política de um estado inteiro, já que a política paulista não se resumiria a uma ou outras liderança ${ }^{8}$.

Em rápida passagem também Schwartzman (1975) oferece uma das primeiras tentativas mais analíticas de interpretação do problema de que São Paulo "não deu origem a partidos bem estruturados e de tipo representacional" como seria de se esperar, isso teria ocorrido porque os interesses econômicos do estado eram topicamente atendidos e porque eram voltados à exportação e por isso pouco atentos aos assuntos internos em geral (p.146). Já critiquei anteriormente esse tipo de viés que não percebe a política como dotada de interesse per se. Mas aqui há ainda outros problemas: a indefinição de "interesses pontuais" e, especialmente, presumir que interesses exportadores não necessitam atentar para assuntos internos - afinal, não necessitariam nem mesmo das políticas tributária e econômica?

Em sentido oposto, há contudo a contribuição mais interessante até hoje no que se refere à explicação da discrepância partidária em São Paulo na democracia de 194. Refiro-me ao livro em que Regina Sampaio (1982) estuda o adhemarismo e a formação do PSP, ambos fenômenos paulistas. Sampaio sugere que a consolidação desse partido diferente dos nacionais no estado teria como conseqüência a tomada de um espaço importante na política paulista, que grandes partidos nacionais como o PSD e o PTB tenderiam a ocupar. Isso teria levado à baixa consolidação dessas legendas em São Paulo, o que estaria, parece implícito, na origem da suposta marginalização política dos paulistas. Mesmo lacônicos e germinais na investigação da questão, por terem outros objetivos, seus apontamentos são contribuições das mais vitais para a retomada do problema nesta pesquisa. Pretendo desenvolver o argumento de Sampaio e usá-lo como ponto de diálogo para meus próprios argumentos sobre o período no último capítulo. Porque são os únicos até hoje que avaliam a interpretação das dinâmicas da própria política paulista e a relação dela com a nacional. Ou seja, para entender o

\footnotetext{
${ }^{8}$ Essa discussão pode consistir em um tema de pesquisa muito interessante. Analogamente, seria curioso especular a importância da morte, por exemplo, de Juscelino Kubitschek, Carlos Lacerda e João Goulart para a formação da oposição à ditadura de 1964.
} 
problema, será preciso olhar para como se deu a relação entre a política de São Paulo e a do Brasil.

Ainda mais se levarmos em consideração que a idéia de partidos nacionais fracos em São Paulo contraria o duplo fenômeno que estaria em curso no sistema brasileiro segundo Olavo Brasil da Lima Jr. (1983): a penetração regional dos partidos nacionais e a nacionalização dos partidos regionais. Será, então, que esse diagnóstico de consolidação da democracia brasileira de 1945, feito por Lima Jr., não estaria acontecendo exatamente em São Paulo? Antes de mais nada, há controvérsias sobre se estaria mesmo ocorrendo a nacionalização dos partidos regionais brasileiros naquela democracia. Para Wanderley Guilherme dos Santos (1986) e também para Jairo Nicolau (2004), a afirmação não procede. Partidos como o PSP (forte em São Paulo), o PR (Minas Gerais), o PL (Rio Grande do Sul) e outros menores, não teriam diminuído sua dependência em relação a seus estados, nem aumentado o número de estados necessários para formarem a maior parte de suas bancadas legislativas federais. Enquanto por sua vez, Antônio Lavareda (1991) aproxima-se mais do diagnóstico de Lima Jr., ao assinalar que o sistema político de 1945-64 viveu todo tempo em um processo de fragmentação partidária: algo como a migração de um regime tripartidário para outro mais fortemente multipartidário.

Contudo, tanto apesar das controvérsias sobre a real nacionalização dos partidos regionais brasileiros, como por causa da falta de discordâncias sobre a crescente penetração regional dos partidos nacionais, penso que o diagnóstico de Lima Jr. pode ser um ponto de partida muito interessante para operacionalizar a questão do papel político de São Paulo na democracia passada. Nem que seja do ponto de vista teórico, no sentido de orientar o caminho de investigação: parece que a literatura dá sérios indícios de que o sistema partidário da democracia de 1945 teve um desenvolvimento peculiar em São Paulo, quer seja por se tratar 
do único estado em que nenhum dos três grandes partidos brasileiros prosperou, quer seja por se tratar do único estado do Brasil em que um partido regional foi predominante.

Processos políticos que delimitaram a atuação paulista na política nacional podem ter a ver com essa dimensão partidária, o que faz sentido com a nova realidade posterior à queda de Vargas. Discorrer sobre o que se considera menor influência dos políticos paulistas na política nacional da democracia de 1945 implica, por se tratar de um período democrático, em considerar "eleições" e "partidos políticos". Ora, considerando-se os procedimentos democráticos daquele período minimamente bem operantes, não se pode esquecer que para os políticos de qualquer estado ou região poderem influenciar sobremaneira a política nacional, deveriam passar pelo lastro do voto. E sem dúvida, em geral tinham de passar pela construção de relações partidárias - a despeito de exeções como Jânio Quadros.

Mas exatamente por ser exceção, pode ser que confirme uma regra - ou melhor, uma recorrência. As pontes partidárias que, via de regra, permitiam a ascensão política do nível estadual ao nacional (LIMA Jr., 1983), eram precárias em São Paulo. Parece promissor, portanto, que procuremos entender um pouco melhor a situação e a formação dos partidos paulistas. Evidentemente, não creio que se possa deter, logo de início e por princípio, apenas nessa dimensão. Simpatizo com a idéia e portanto suspeito que a queda de influência da política paulista sobre a nacional possa ter como uma de suas definições a "não consolidação dos partidos nacionais em São Paulo e não nacionalização das forças partidárias paulistas”. Mas não pretendo contribuir à literatura com mais uma afirmação apriorística. Não pretendo dar isso como pré-estabelecido. A literatura nunca demonstrou nem que "deprivação política" fosse só a situação partidária paulista, nem que a situação partidária paulista fosse assim tão discrepante. É necessário ir além das impressões, nos próximos capítulos.

Nesse sentido, proponho que investiguemos empiricamente, a seguir, algumas das principais sugestões que a literatura apresentou, e que sumariei acima, como explicações para 
as idéias genéricas e fugidias de "ocaso" ou "deprivação" política dos políticos paulistas entre 1945-64. Através disso, poderemos separar o que retomar e o que corrigir para o esforço de construir um novo quadro analítico sobre a situação política de São Paulo. Proporei também que, independentemente de ganhos econômicos ou do desenvolvimento político do estado de São Paulo, minha definição para o assunto tentará retomar o argumento de Lima Jr. embora o negando para o caso da política paulista: em São Paulo, nem os partidos e quadros nacionais penetraram, nem seus quadros e partidos próprios se nacionalizaram. Mesmo assim, veremos se e até que ponto essa situação dos partidos paulistas foi verdadeira. 


\section{Capítulo 2}

\section{Silenciosa, mas a todo vapor. A todo vapor, mas silenciosa}

Como comentei, não é segredo, tampouco objeto de discordâncias, o fato de que a economia de São Paulo foi não apenas beneficiária, em geral, de todo o desenvolvimento brasileiro no século $\mathrm{XX}$, como foi geralmente a mais favorecida entre todos os estados ou regiões do país. Essa aceitação independe da literatura que se considere: quer seja a Ciência Política, quer seja a Economia, a Geografia Regional ou a Sociologia. Assim, não é interesse deste trabalho sugerir que durante a democracia de 1945 a economia paulista tenha sido prejudicada. Ou que os interesses de representantes da elite econômica ${ }^{9}$ paulista tenham sido sequer desfavorecidos.

Pelo contrário, tenho consciência e relembro que parti do princípio de que nenhum estado do país lucrou mais com o período aqui estudado do que o estado de São Paulo. E isso era percebido inclusive à época. Não apenas na democracia sucessora do Estado Novo varguista, como também durante essa ditadura: mesmo em 1939, João Frederico Normano, economista brasileiro radicado há muitos anos nos Estados Unidos como professor em Harvard, escreveria que “ouvem-se queixas de alguns Estados de que São Paulo é muito favorecido pela União" (1939, p.152). Favorecido intencionalmente ou não - isso é outra discussão que tangenciarei no capítulo seguinte - é fato que no ano em que Normano escrevia, o PIB paulista já atingia 31\% do nacional, praticamente a média do que iria representar desde

\footnotetext{
${ }^{9}$ Esclarecerei um pouco melhor adiante. Mas como podem notar desde já, utilizo a idéia de "elites" em um sentido muito mais frouxo e esquemático do que aquele discutido em geral pela Sociologia Política ou mesmo por parte da Teoria das Elites. É bom sublinhar que, analiticamente, faço plena diferença entre elites "econômicas", "sociais" e "políticas" - dimensões que, para mim, não se justapõem obrigatoriamente. E mesmo quando o fazem, implicam lógicas de atuação distintas em cada uma delas, por parte do ator considerado.
} 
aquele ano até 2006 (35\% do PIB do Brasil). E o número de estabelecimentos industriais de São Paulo havia passado de 4.145 em 1920 para 14.225 em 1940 (crescimento de $243 \%)^{10}$.

Mas se os industriais paulistas teriam sido beneficiados pelo início de política industrial ensejada pelo Estado Novo varguista, era ainda pouco em comparação ao que se daria na democracia de 1945. O PIB industrial paulista, que já era 36\% do nacional em 1939, passou para 48\% em 1949 e para 54\% do nacional em 1959. Para Wilson Cano (1998:29), “até meados da década de 50 (...) São Paulo detinha mais da metade da produção industrial do país, após o que seria reforçada pelas inversões decorrentes do Programa de Metas, com a instalação da indústria pesada”. E na crítica de Francisco de Oliveira (1989:41), no período estudado em seu livro, 1939 a 1963, “o intenso crescimento industrial ocorrido na região Sudeste - especialmente em São Paulo - é obviamente o epicentro das transformações estruturais da economia brasileira como um todo e, igualmente, de uma certa redivisão interregional do trabalho no país".

E não era apenas o setor industrial paulista que se fortalecia. Durante o Estado Novo, o peso da agricultura paulista na economia nacional até mesmo aumentou, ainda que voltasse a diminuir durante a democracia que se seguiu. Em números, o PIB agropecuário de São Paulo passou de $25 \%$ do nacional em 1939 para $30 \%$ em 1949, voltando a $22 \%$ em 1959. Além disso, Cano $(1977,1998)$ observa com muita propriedade que a agricultura de São Paulo já era desde antes de 1930 a mais moderna e bem estruturada do país. E esse quadro se manteve, como atesta o grau de mecanização agrícola, medido por exemplo pela relação entre área utilizada com lavouras e pastagens e o uso de tratores (1000ha/trator). Em 1940, enquanto São Paulo apresentava índice de 7,6 contra 31,7 no todo do país, essa taxa evoluiu em 1950 para 2,9 em São Paulo e 15,3 no país, e chegou em 1970 sendo 0,2 nas terras paulistas contra 1,2 no país (CANO, 1998:318). Ou seja, enquanto a mecanização do campo por tratores em São

\footnotetext{
${ }^{10}$ Neste capítulo, dados sem citação de referência referem-se a material compilado de múltiplas fontes: Anuários Estatísticos do Brasil (1909 a 2006), Censos Industriais do IBGE (1969 a 1950), Contas Públicas Nacionais (1930 a 2006).
} 
Paulo era 4 vezes maior do que a média do Brasil em 1940, passou a ser 5 vezes maior em 1950 e 6 vezes maior em 1970.

Sendo inexistente qualquer animosidade para com a evolução da economia paulista mesmo sob Vargas, resta posto que, na dimensão econômica, o varguismo e o desenvolvimentismo pós-Getúlio não possuíam apelo ou projeto regionalista. Eram despretensiosos quanto ao caráter econômico regional. Howard Gauthier e Robert Sample, em artigo de 1977, colocam a questão de modo apropriado:

Apesar do governo ter seguido uma estratégia de desenvolvimento setorial seletivo, pouca atenção foi dada à locação espacial do crescimento. O padrão regional do crescimento durante a década de 40 e o início da década de 50 foi, sem dúvida alguma, um resultado da seleção de setores industriais para desenvolvimento, muito mais do que qualquer estratégia consciente de considerar ou tratar desigualdades no crescimento regional (1972:10)

Não parece claro, portanto, que os modelos de desenvolvimento econômico adotados entre 1930 e 1964 tivessem o interesse de privilegiar ou prejudicar economicamente um dado estado nacional ou uma dada região. E mais importante neste ponto: não visavam, de modo algum, prejudicar os interesses econômicos de São Paulo. Nem mesmo do ponto de vista dos investimentos feitos pelo governo federal naquele estado se pode dizer que a situação dos paulistas tenha piorado quer com o Estado Novo de Vargas, pelo contrário. Infelizmente, não há dados sistemáticos disponíveis em fontes oficiais sobre as despesas realizadas pela União em cada estado da nação na democracia de 1945. Mas uma coisa é certa: quanto ao Estado Novo, se desconsiderarmos as cifras investidas no Distrito Federal pois agregam os gastos burocráticos e não alocados ${ }^{11}$, as despesas do poder central em São Paulo entre 1933 e 1945

\footnotetext{
${ }^{11}$ Desconsiderei das despesas realizadas no total do país as que foram efetuadas nos distritos federais (primeiro Rio de Janeiro até 1959, depois Brasília). As somas investidas ali eram evidentemente muito superiores às da maioria dos outros estados, por questões meramente burocráticas e de catalogação da despesa. O que distorcia os dados.
} 
passaram a representar, em média, $22 \%$ do gasto total no país, contra uma média de $8 \%$ entre 1910 a 1928.

Ora, resta nítido que não se pode inferir desses dados que o governo do país tenha passado a prejudicar São Paulo, no que se refere às despesas que invertia nesse estado. Até poruqe se a federação arrecadou ali muitíssimo mais do que gastou, isso foi apenas o mesmo padrão de todo o século XX. E se do ponto de vista do controle da política os paulistas foram prejudicados, certamente isso não pesou na distribuição federativa de recursos. Pegue-se outro dado, agregado a partir do anexo 1: entre 1933 e 1945, as liberações de recursos do Banco do Brasil no estado de São Paulo perfizeram uma média anual de $27 \%$ do total no país, enquanto essa média anual foi de $29 \%$ entre 1945 e 1958 e de $22 \%$ de 1985 a 2005 . Economicamente, portanto, concordo com o ponto já pacífico na literatura: “os paulistas”, se assim considerados como bloco único, lucraram com o período 1930 a 1964. A economia de São Paulo beneficiou-se. O estado em si não foi prejudicado.

Comprovado e aceito isso, pode-se avançar sobre a dimensão política da relação entre os paulistas e a política nacional. Como já afirmei ao introduzir este trabalho, essa realidade econômica de modo algum torna desinteressante investigar a inserção política dos paulistas na arena nacional. Pelo contrário. Se Simon Schwartzman acha que "os interesses econômicos [de SP] tendiam, geralmente, a ser atendidos em termos específicos, não dando margem, assim, à formação de uma estrutura de demandas políticas mais permanente" (1975:146), de minha parte estou mais de acordo com a resposta dada a ele por Regina Sampaio (1982:29): "a resposta que o autor sugere para esta questão, longe de resolver antes repõe o problema". Nada autoriza crer que, ao ter ganhos econômicos, um dado grupo social ou econômico não almejasse comandar seu destino político, decidir seu futuro ou influir nas decisões de longo prazo de seu setor, de seu estado ou do país. Diga-se de passagem, não é exatamente isso que se costuma dizer da reação dos próprios paulistas aos interventores tenentistas impostos por 
Vargas como governadores do estado de São Paulo? Ou seja, que os paulistas não admitiam não governarem a si mesmos?

Antes de continuar nessa trilha, porém, necessito salientar que há pelo menos dois riscos relevantes inerentes ao estudo da questão federativa, mas ainda maiores quando se busca analisar a relação entre as políticas estaduais e a política nacional. Um perigo sempre iminente é incorrer no que poderíamos chamar de metonímia analítica, ao estudarmos estados federados quando deveríamos estudar seus atores políticos intra-estaduais. Trocar o conteúdo pelo continente. O outro, análogo, é a personificação desses estados como se eles próprios fossem atores políticos em si mesmos. É verdade que muitas vezes usamos o nome de um estado, cidade ou país apenas abreviando frases extensas como 'os políticos de São Paulo', 'as indústrias de São Paulo', sem maiores danos. No sentido que comenta Schwartzman (1975:28): “unidades geográficas [.... não passam de uma maneira cômoda de referir-se a complexos sociais de outro tipo". Ou seja, usamos muitas vezes os termos como verdadeiras metonímias de linguagem, o que não implica maiores danos.

O perigo é se deixamos isso desembocar naquela troca propriamente analítica ou na personificação. O que pode acontecer, especialmente, através de generalizações. O estado de São Paulo como um todo teve seu poder diminuído na federação re-inaugurada em 1946? Sem dúvida, já que todos os estados o tiveram ao abandonar-se o ultra-federalismo anterior a 1930, como vimos no capítulo anterior. Mas e os políticos profissionais paulistas, as elites econômicas ou sociais do estado? Essa é outra questão. São Paulo esteve menos presente na política nacional? Depende de quais paulistas: o que aconteceu com o PSP, a UDN, o PSD, o PTB e o PCB? Há indícios factuais que corroborem as diferentes afirmações da literatura sobre o "lugar" de "São Paulo" na federação? E aqui, "lugar" de "São Paulo" é apenas figura de linguagem. 
A seguir, pretendo mostrar alguns dados que permitam repensar várias das afirmações feitas pela literatura para essa questão, tal como as apresentei no capítulo anterior. Dados que, por um lado, permitam refletir sobre variáveis que a literatura relaciona deterministicamente com a idéia genérica do ocaso político paulista durante a democracia de 1945 . E por outro lado, que permitam avançar em uma especificação empírica para o que teria sido esse ocaso de modo que nos outros capítulos torne-se possível construir algumas sugestões próprias à guisa de explicação. Primeiro, abordo rapidamente as dimensões: populacional, tamanho do eleitorado, desenvolvimento econômico - esse nas chaves da industrialização e urbanização. Lembrando-se da ótica do descompasso estrutural, questiono: ora, mesmo se o regime político brasileiro desse espaço à vocalização dos interesses econômicos sobre a política como queria Schwartzman (1975), ainda assim isso não necessariamente garantiria vitórias eleitorais. E na ótica da barganha estatista, tampouco haveria como garantir derrota aos paulistas nas urnas por barganha alguma que não fosse feita com o eleitorado.

Também abordarei o problema da sub-representação de São Paulo nas cadeiras parlamentares, perguntando-me no que isso influiria por exemplo no desempenho de paulistas em outros âmbitos, outros cargos, nas eleições. Apenas em seguida entrarei na discussão propriamente dita sobre o que podemos afirmar positivamente sobre a suposta decadência política dos paulistas na democracia de 1945. Entendo que essa possa ser uma inversão na ordem usual através da qual se apresentam variáveis de pesquisa. Mas opto por isso dado o caráter peculiar deste trabalho: afinal, se o senso comum e a literatura esperam que essas dimensões normalmente seriam explicadores ou mesmo causas da força política dos paulistas, resta-me analisar essas inferências e responder a elas no mesmo patamar de abstração. Dito de outro modo: se optasse por definir primeiro o que eu entenderia como "deprivação política" dos paulistas na democracia de 1945, não estaria respondendo tanto à literatura, mas mais a meus próprio interesses de pesquisa. Ademais, como pretendo demonstrar, julgo que nesses 
casos seja possível desconstruir grande parte das suposições mesmo sem pré-definir o objeto. O que só denuncia o alto grau de pressuposição dos argumentos da literatura.

Feito isso, aí sim começo efetivamente a verificar a situação dos paulistas na política nacional. Como sugeri no capítulo anterior, as poucas vezes em que a literatura especificou o assunto, falou basicamente na situação atípica dos partidos nacionais no estado de São Paulo, durante a democracia de 1945. E vez ou outra sobre a penetração de paulistas nas burocracias do Estado nacional, especialmente nos ministérios centrais. Pretendo avaliar primeiro as nomeações ministeriais e em seguida, mais extensamente, o desempenho dos partidos políticos nacionais em São Paulo e dos políticos paulistas no nível nacional. Deixo para essa parte do texto a verificação das impressões existentes sobre a situação dos partidos políticos naquele estado, separando essa premissa das dimensões econômicas e demográficas por se tratar de uma das únicas proposições concretas sobre o significado de "queda política dos paulistas". Creio que a análise dos ministérios, mas principalmente da situação política dos partidos nacionais em São Paulo e dos políticos paulistas em eleições nacionais, poderá clarificar e tornar menos pré-suposto o sentido do que teria sido essa queda de influência durante a primeira democracia do país.

\section{População, eleitorado e desenvolvimento econômico}

O passo mais elementar, muito provavelmente, é verificar a relação direta que tanto se supõe existir entre força econômica e demográfica e a força política. São dois pressupostos, em geral, que prevêem a explicação de relevância política originada no tamanho populacional ou eleitoral e no tamanho e qualidade da economia. Ou seja, antevêem maior peso político (qualitativo ou quantitativo) dos grupos que são maiores (quantitativamente) quanto à sua relevância econômica, mas também quanto à sua população e quanto ao seu eleitorado. 
Quanto a essas duas últimas dimensões, o pressuposto evidente é o ideal do "1 homem, 1 voto". Nem sempre há muita clareza ou muita elaboração sobre o mecanismo pelo qual, por exemplo, isso explicaria o grande predomínio da política paulista sobre a nacional durante a República Velha. Afinal, tanto aquela república não tinha seu funcionamento mais central na correspondência fiel aos votos como, tal como se nota no gráfico 1 a seguir, São Paulo possuía menos habitantes e menos eleitores do que Minhas Gerais.

O princípio parece bem mais claro para a democracia de 1945: espera-se que os paulistas pesem mais sobre a nação porque o peso de sua população e de seu eleitorado seriam maiores nesse estado. Mas há ao menos três dificuldades nesse tipo de suposição, uma vez que mesmo em regimes democráticos um grande colégio eleitoral não garante boa inserção política a um dado distrito por várias razões. Em primeiro lugar, pode haver sub-representação legislativa dos distritos. Segundo, afora as eleiç4oes nacioansi legislativa, nada garante que as elites políticas desse distrito político consigam projeção o bastante sequer para se candidatar e só depois de candidatas poderiam beneficiar-se do peso de seu eleitorado conterrâneo. E principalmente, em terceiro lugar, mesmo se o grande contingente de eleitores paulistas tivesse sempre candidatos de São Paulo em quem votar, nada garante que efetivamente optariam por esses candidatos.

Dados dos gráficos 1 e 2 já são capazes de responder se a importância de população e do eleitorado como variáveis isoladas podem explicar porque os políticos de São Paulo têm papéis tão diferentes ao longo da história da República. E a resposta é que, parece que não podem explicar. Para começar, volto a sublinhar que em ambos os gráficos a curva que representa São Paulo ultrapassa a curva que representa os contingentes de Minas Gerais apenas no final da década de 1930. Ou seja, durante a República Velha, em que o destaque dos paulistas na vida pública nacional teve seu ápice, a população e o eleitorado paulistas não 
eram sequer os maiores do Brasil. E na verdade, a concentração paulista em termos de habitantes e de eleitores é bastante maior na democracia de 1945-64 do que era antes de 1930.

Outro dado interessante: ainda que a democracia atual possua concentração populacional paulista maior, o mesmo não se pode dizer do eleitorado, cujas porcentagens mantêm-se muito mais estáveis no tempo. Ora, a participação paulista na população e no eleitorado nacionais foi maior exatamente no momento em que os políticos de São Paulo teriam perdido influência política sobre a nação. Os gráficos recomendam cautela com a idéia, perigosamente intuitiva, de que esses elementos demográficos poderiam explicar a diferença de prevalência política em comparação com a República Velha ou com os dias de hoje. Ou seja, o vínculo entre eleitorado/habitantes e influência política não desobedece o pressuposto apenas em 1945-64, mas mesmo nos outros períodos em que a situação da política paulsita foi vista como mais próxima do seu dever ser.

Analisar o efeito do tamanho ou da qualidade da economia sobre a relevância política é um pouco mais complicado. Mas creio ser possível avançar alguns dados sugestivos, que apontam no sentido de que o predomínio de políticos paulistas não caminhou, em nenhum momento, seguindo a força econômica ou o nível de sofisticação da modernidade paulista. Ou seja, outra vez, não é que isso não ocorreu em 1945-64. Não ocorreu mesmo em outros períodos. Mesmo assim, esse tipo de dado que refuta a coincidência, a concatenação ou anterioridade causal, é de fato muito elementar. Demonstrar que os períodos de maior desenvolvimento sócio-econômico de São Paulo não coincidiram com os períodos tidos como de maior força política é um esforço sujeito a uma aparente insuficiência digna de nota. $\mathrm{O}$ problema é que ao mostrar que a força política dos paulistas não dependeu de coincidência temporal com a economia, estou questionando o que espera o senso comum, mas nada posso demonstrar contra a idéia de que o maior desenvolvimento paulista deveria levar a maior 
Gráfico 1 - Porcentagem da população de estados selecionados em relação ao total do país (1890-2006)

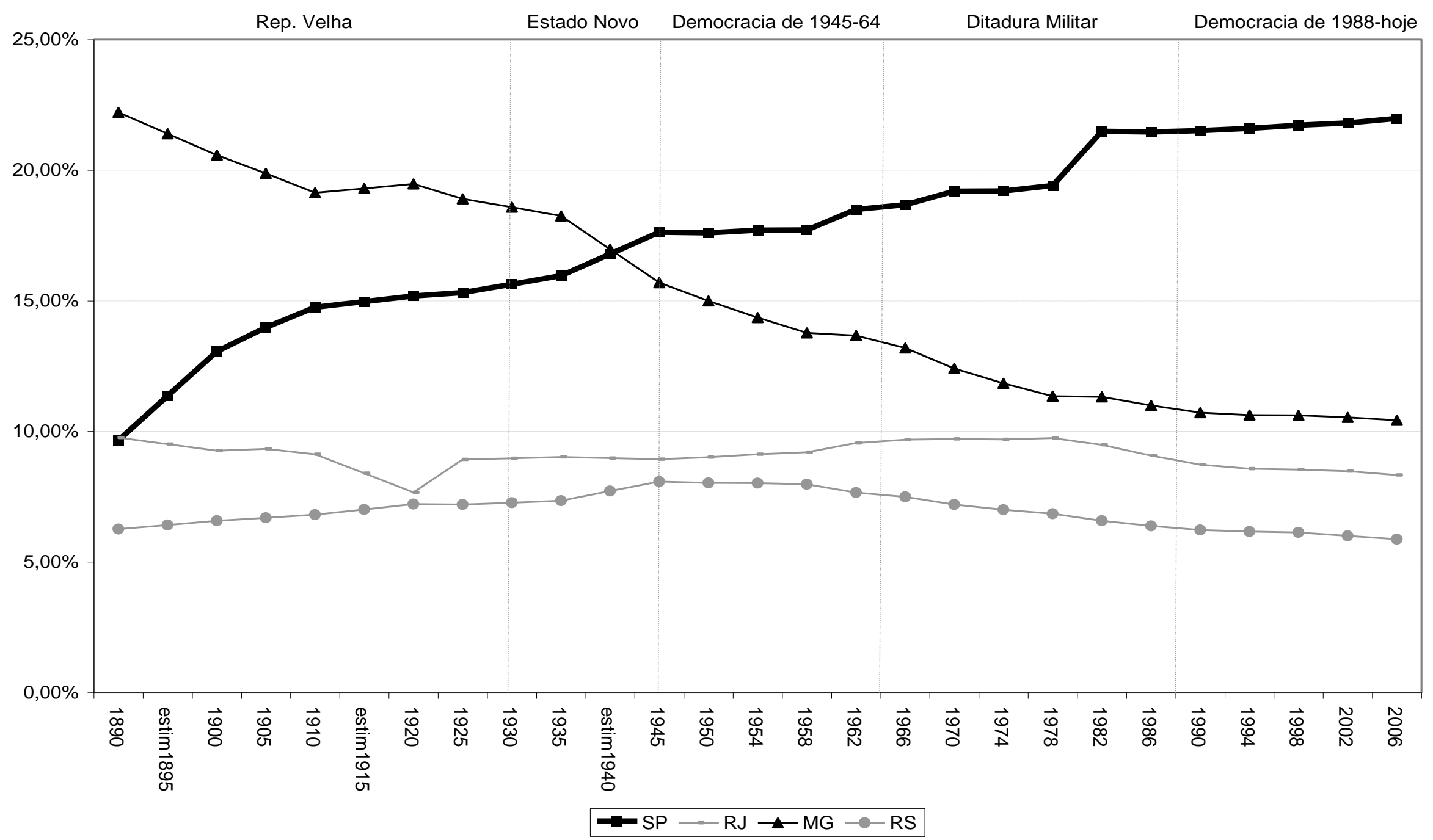

Fonte: Antes de 1940: IBGE, Anuário estatístico do Brasil 1946. Rio de Janeiro: IBGE, v. 7, 1947. A partir daí, IBGE. A partir de 1940, diversos censos do IBGE. Obs: resultados para os anos de 1895, 1915 e 1940 são estimativas, não dados censitários. Estimativas feitas pelo próprio IBGE. 
Gráfico 2 - Porcentagem do eleitorado de estados selecionados em relação ao total do país (1908-2006)

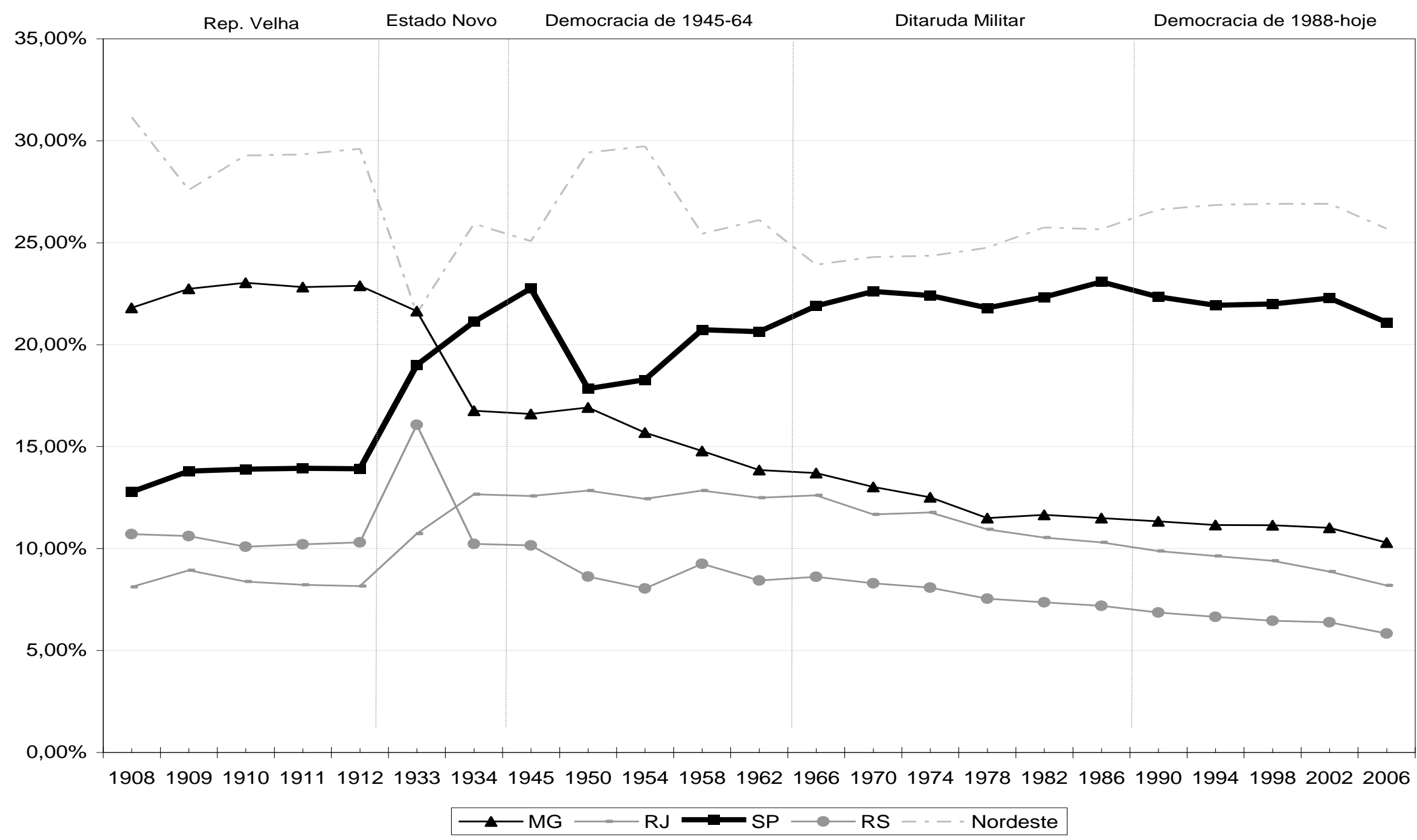

Fonte: TSE e site: http://jaironicolau.iuperj.br/ 
influência na política nacional. Mas também pudera: existe algum expediente acadêmico rigoroso que possa refutar o dever ser?

Classicamente, o paradigma de modernização e o desenvolvimento sócio-econômico ideal residem nas esferas do poder econômico, da industrialização e da urbanização. De preferência conjuntamente (na discussão específica do período, ver JAGUARIBE, 1953; SOARES, 1973, 1981; entre outros). Para Schwartzman, por exemplo, "São Paulo representa no país um caso único e atípico de industrialização e urbanização simultâneas o que afeta sua utilização como 'modelo' para o resto do Brasil”' (1975:17). Pois bem, ainda que tangencialmente, é possível investigar se esse aspecto do desenvolvimento paulista modificou-se ao longo do século XX. As distribuições geográficas de alguns indicadores podem ser interessantes para tentar verificar esse ponto de vista. Qual a participação de São Paulo na economia nacional? E quanto concentra das taxas de urbanização do país? E do PIB industrial? Em linhas gerais, basicamente: teria havido significativa alteração da situação econômica e do desenvolvimento sócio-econômico de São Paulo nos períodos em que sua situação política fora diferente?

As tabelas de número 1, a seguir, tentam capturar o impacto do desenvolvimento da economia paulista no fator urbanização.

Tabela 1.1 - Porcentagem de cada estado ou região na população urbana nacional, em cada ano de censo IBGE

\begin{tabular}{lrrrrrrrr}
\hline & 1940 & 1950 & 1960 & 1970 & 1980 & 1991 & 1996 & 2000 \\
& & & & & & & & \\
SP & 24,60 & 25,58 & 25,62 & 27,41 & 27,59 & 26,41 & 25,81 & 25,06 \\
MG & 13,15 & 12,38 & 12,29 & 11,64 & 11,17 & 10,62 & 10,62 & 10,63 \\
RJ & 17,18 & 18,07 & 16,66 & 15,18 & 12,89 & 10,99 & 10,41 & 10,01 \\
RS & 8,03 & 7,57 & 7,61 & 6,82 & 6,53 & 6,30 & 6,16 & 6,03 \\
NE & 26,25 & 25,26 & 24,01 & 22,57 & 21,84 & 23,22 & 23,72 & 23,90 \\
& & & & & & & & \\
Brasil & 12880182 & 18782891 & 31303034 & 52084984 & 80436409 & 110990990 & 123076831 & 137775550 \\
\hline
\end{tabular}

Fonte: dados de recenseamentos do IBGE, 1940 a 2000. Compilação em: IBGE (2006). 
Tabela 1.2 - Taxa de urbanização (\% pop urbana) de São Paulo e do Brasil

\begin{tabular}{lrrrrrrrr}
\hline & 1940 & 1950 & 1960 & 1970 & 1980 & 1991 & 1996 & 2000 \\
& 44,12 & 52,59 & 62,61 & 80,33 & 88,64 & 92,80 & 93,11 & 93,41 \\
São Paulo & 31,24 & 36,16 & 44,67 & 55,92 & 67,59 & 75,59 & 78,36 & 81,23 \\
Brasil & & & & & & & & \\
$\begin{array}{l}\text { Porcentagem que a de SP } \\
\text { é maior que a do Brasil: }\end{array}$ & 41,26 & 45,45 & 40,15 & 43,65 & 31,14 & 22,76 & 18,82 & 14,99 \\
\hline
\end{tabular}

Fonte: dados de recenseamentos do IBGE, 1940 a 2000. Compilação em: IBGE (2006).

Lamentavelmente, não há dados sobre urbanização anteriores a 1940, data do primeiro censo geral do IBGE. Mesmo assim, embora não possamos incluir nas comparações a República Velha, as informações acima são de interesse. Nota-se, primeiro, na tabela 1.1, que o peso da população urbana de São Paulo na população urbana nacional manteve-se inalterado ao longo de todo o século XX. Em segundo lugar, pode-se observar na tabela 1.2 que o suposto descenso político de São Paulo na democracia de 1945 teria, nesse caso, ocorrido em momento em que o peso da urbanização paulista em comparação com a urbanização do país manteve-se estável. Ao contrário: a taxa de urbanização do resto de Brasil sobe e com isso melhora a relação entre a taxa paulista e a nacional exatamente à medida que se instaura a atual democracia do país, ou seja, período de muito maior presença política paulista na política nacional. Dito de outro modo, a taxa de urbanização paulista é muito menos discrepante da taxa de urbanização nacional exatamente quando o peso político dos paulistas é tido como bastante maior. Mais importante: mesmo não havendo dados sobre urbanização na República Velha, os dados de 1940 indicam um patamar a que se chegou ao final dessa primeira república e do Estado Novo. Ora, significa dizer que a política paulista foi vista como forte na política nacional em dois perídos, antes de 1930 e hoje, a despeito de as relações entre urbanização paulista e nacional serem profundamente discrepantes entre os dois momentos. 
A seguir, apresento no gráfico 3 a porcentagem dos Produtos Internos Brutos estaduais em relação ao PIB nacional, entre 1939 e 2006. E para um quadro mais específico, o gráfico de número 4 mostra, a partir de 1940, o peso do PIB industrial de São Paulo - e de alguns outros estados e regiões selecionados - dentro do PIB industrial do país. Em primeiro lugar cabe ressaltar que o PIB paulista é muito superior aos de outros grandes estados nacionais já em 1939, primeiro ano para o qual existem dados desagregados por estado. Em segundo lugar, a maior variação e também o pico atingido pela porcentagem que o PIB de São Paulo representa da produção nacional foram na ditadura militar de 1964. Em terceiro e, certamente, mais importante para esta pesquisa, não há diferença visível entre o quanto a economia paulista predominava na economia nacional entre 1945 e 1964 e o quanto o faz hoje. Em média, a produção econômica paulista representou, na democracia de 1945, 34,91\% da produção nacional. E de 1988 até 2006, representou 34,84\%. Em todo o período considerado, de 1939 a 2006, aliás, o PIB de São Paulo teve um coeficiente de variação de apenas 5,3\% ${ }^{12}$, o que significa que foram dessa magnitude as variações anuais em torno da média paulista entre esses anos. Uma variação certamente muito pequena no quanto São Paulo concentrava e concentra do PIB brasileiro. E que é, diga-se de passagem, não muito menor do que a encontrada para o Nordeste: em todos esses anos, um coeficiente de variação de apenas 9\%. A despeito de políticas de combate à desigualdade regional, o PIB dos estados nordestinos somados representou em média 14,08\% do nacional entre 1945 e 1964, e em média $12,83 \%$ de 1988 até 2006.

A situação é ainda mais inusitada quando tomamos em conta o gráfico 4, retratando os PIB industriais. A economia de São Paulo teve sua participação na produção industrial nacional durante a democracia de 1945 em forte crescimento, tendo atingido seu auge no fim desse período e durante a ditadura subseqüente. E não apenas essa participação na indústria

\footnotetext{
${ }^{12}$ Indicador muito elementar, o coeficiente de variação $(\mathrm{CV})$ dá-se pela divisão do Desvio Padrão $(\sigma)$ pela Média $(\bar{X})$.
} 
nacional vem sendo significativamente declinante na democracia atual, como vem ficando sempre abaixo do que era entre 1945 e 1964. É bem possível que essa mudança tenha a ver com o espraiamento da industrialização, que segundo Francisco de Oliveira (1990) deixou de ser a dimensão diferenciadora entre regiões desenvolvidas e sub-desenvolvidas, tornando a economia nacional mais complexa do que a lógica anterior industriais $\mathrm{x}$ agricultores. Mas de todo modo, o ponto se mantém: independentemente do que se entenda por declínio político dos paulistas na democracia de 1945, já que nem mesmo aqui adotei uma definição prévia, não parece difícil sustentar a relação entre esse fenômeno e a industrialização? Considere-se especialmente as diferenças entre os dados atuais e aquele que se pode imaginar para a República Velha através do primeiro ano das série dos gráficos.

Ora, se o peso econômico paulista não variou e não é diferente na República Velha, na democracia de 1945 ou na democracia de 1988, como pode explicar a diferença de desenvolvimento econômico e social que deveria dar conta de justificar seu peso político? E se o peso industrial paulista foi maior enquanto os políticos de São Paulo teriam, por suposto, menos influência política na nação e menor hoje quando têm mais influência, não parece haver algo no mínimo duvidoso nesse raciocínio que liga economia à política de forma tão mecânica? Entendo, como antecipei, que até a pouco se poderia afirmar que esse quadro apenas recoloca um indício de que poder econômico e político dos paulistas eram discrepantes entre si. Ou seja, esse dados estariam apenas servindo de indício a essa tese. Creio, contudo, que essa ressalva vai ficando mais difícil. A não ser que se assuma que a discrepância se inverteu: na democracia atual, então, os paulistas apresentariam poder político maior do que os ganhos econômicos que conseguem auferir do "sistema"? Ou estaria hoje ocorrendo uma barganha estatista às avessas, com os paulistas abocanhando maiores parcelas do poder político mas aceitando menos ganhos econômicos? Apenas aceitando isso poderia se sustentar 
a vinculação direta de causalidade entre economia e política. E a bem da verdade, não acredito que a literatura concordasse com tais ressalvas.

Com isso torna-se possível ao menos questionar a idéia de que a industrialização de São Paulo e sua urbanização, por discrepantes do resto do país, fizessem supor um predomínio político. Para a literatura que apresentei, por exemplo Schwartzman (1975) ou Vianna (1994), o predomínio esperado para São Paulo adviria da evolução do sistema político brasileiro para um sistema mais responsivo às clivagens economicamente determinadas. $\mathrm{Ou}$ seja, peso paulista é condição necessária, mas não suficiente. Para que pudesse se desdobrar politicamente e espraiar a modernidade paulista ao resto do Brasil, era preciso que o sistema político nacional fosse liberalmente político o bastante. Por isso, para Schwartzman (1975), nem mesmo na República Velha São Paulo deixaria de estar politicamente debilitado perto do que seria de se esperar.

Analisemos essa questão. Mesmo que assumamos isso como ponto de partida, é preciso lembrar que houve variações no tempo para o quanto os regimes brasileiros eram politicamente liberais o bastante para serem responsivos à economia nacional. Seria a democracia de 1945 realmente menos responsiva a interesses econômicos do que a democracia de hoje? A literatura não faz parecer. Sabemos há muito tempo que as correntes de pensamento econômico que informaram a evolução do país naquela democracia foram bastante demarcadas e ligadas a grupos e interesses diversos (BIELSCHOWSKY, 1988; LAMOUNIER, 1994). Além disso, se os intensos debates sobre reforma agrária e sobre o desenvolvimentismo, que levaram inclusive à radicalização do sistema (SANTOS, 1986) não significam a vocalização política dos interesses econômicos, o que mais poderia significar?

A montagem das políticas econômicas do período deixa bastante clara as disputas pela representação de interesses, como mostra Sérgio Braga (2008). Se a elite social ou econômica de São Paulo (e se é que ela existe assim monolítica) não conseguia fazer vocalizar seus 
Gráfico 3 - Porcentagem do PIB de estados selecionados em relação ao PIB nacional, de 1939 a 2006

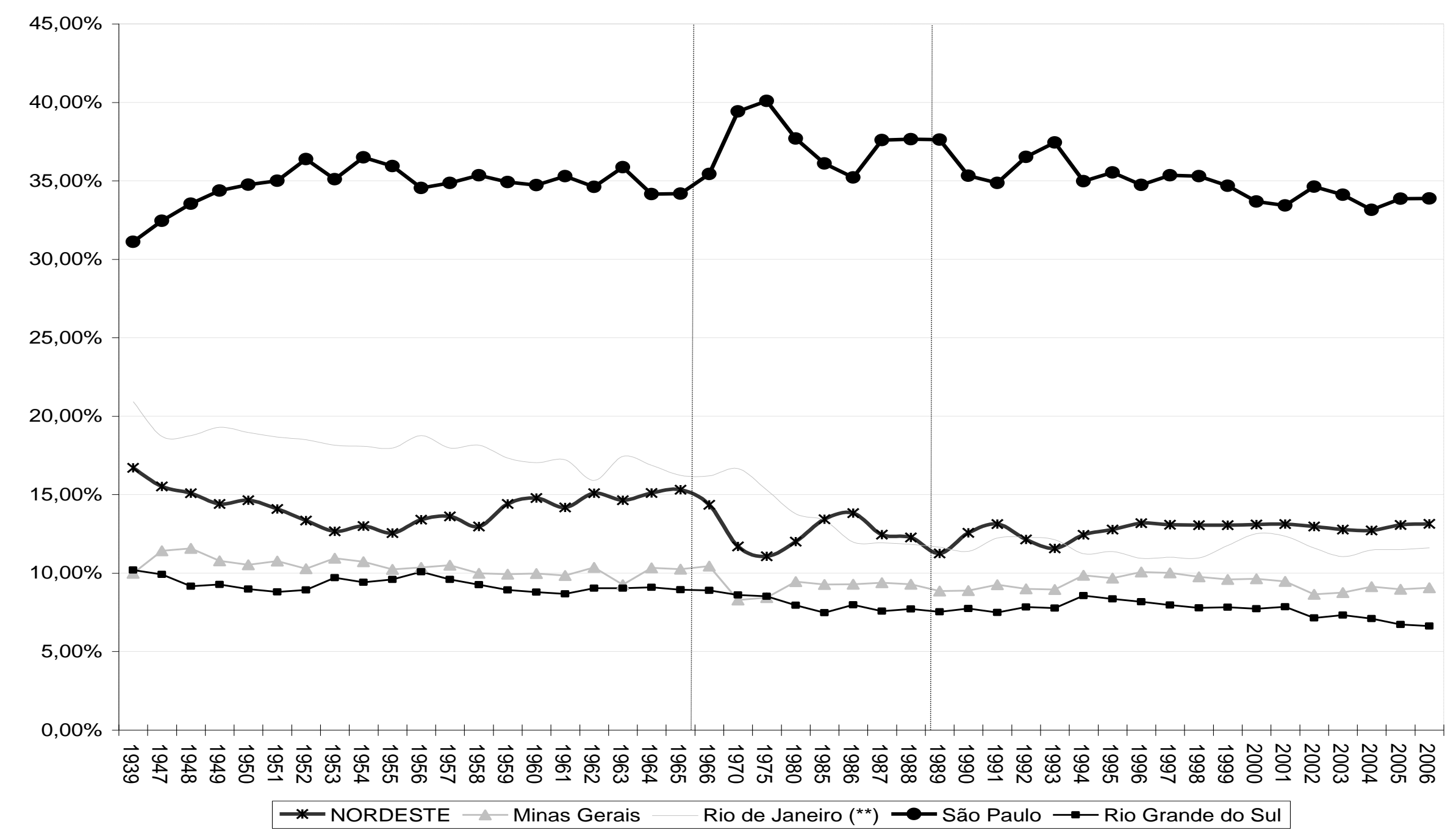

Fonte: IBGE e Ministério do Planejamento. 
Gráfico 4 - Porcentagem do PIB industrial de estados selecionados em relação ao PIB industrial nacional, de 1939 a 2006

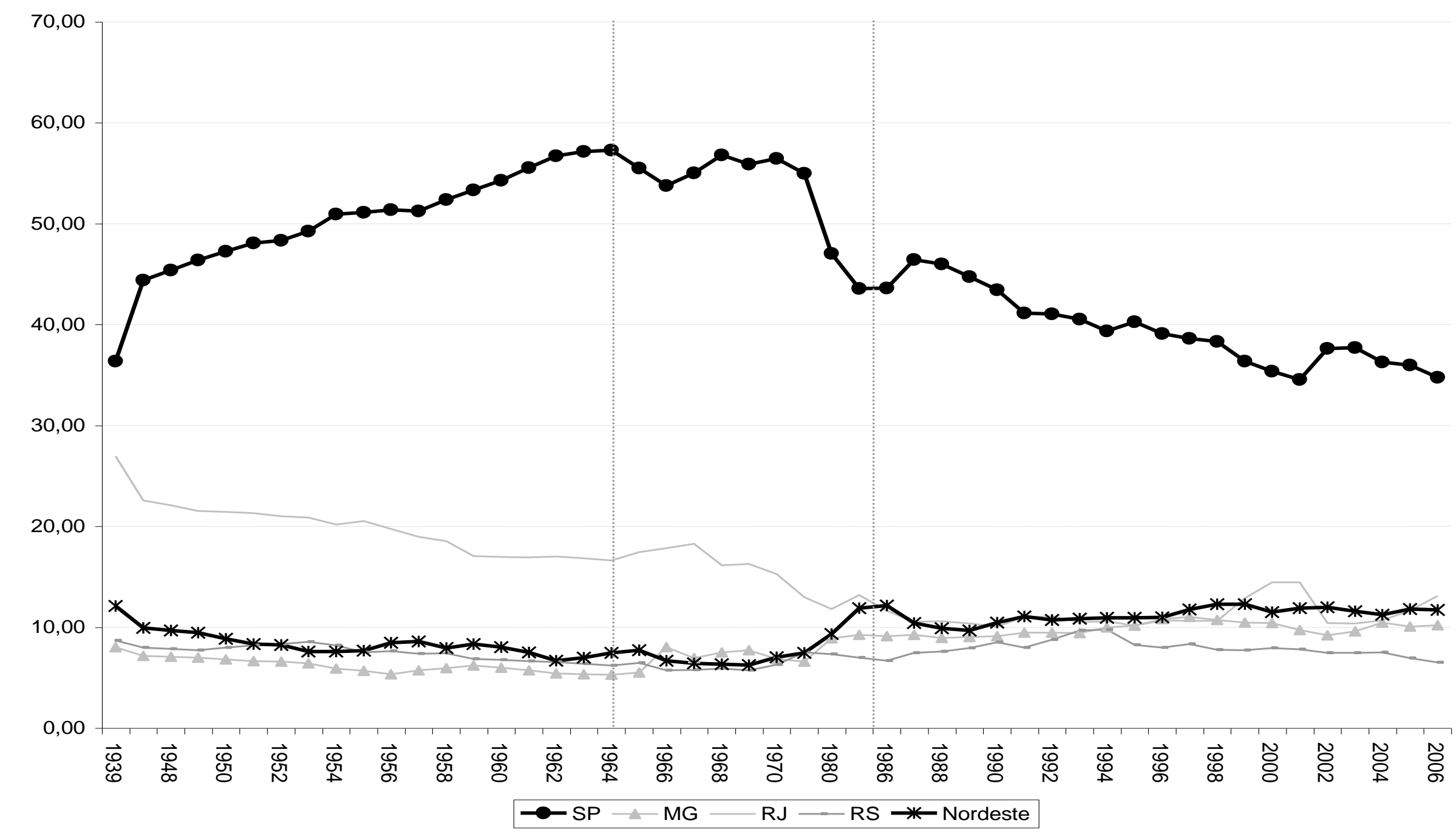

Fonte: Censos Industriais do IBGE, Ministério do Planejamento e IPEAData. 
interesses politicamente por culpa do sistema político, por que é que setores industriais, urbanos e trabalhistas de estados como Rio Grande do Sul, Rio de Janeiro e Minas Gerais conseguiram? Todos os elementos, estruturais ou institucionais, eram iguais para todos. E assim sendo, causa estranheza que nenhuma explicação, com exceção daquela de Sampaio (1982) a que fiz referência, tenha pensado em observar a evolução da própria política formal paulista para entender o problema.

Seria a democracia de 1945 realmente menos responsiva a interesses econômicos do que a democracia de hoje? A literatura não faz parecer. Sabemos há muito tempo que as correntes de pensamento econômico que informaram a evolução do país naquela democracia foram bastante demarcadas e ligadas a grupos e interesses diversos (BIELSCHOWSKY, 1988; LAMOUNIER, 1994). Além disso, se os intensos debates sobre reforma agrária e sobre o desenvolvimentismo, que levaram inclusive à radicalização do sistema (SANTOS, 1986) não significam a vocalização política dos interesses econômicos, o que mais poderia significar?

A montagem das políticas econômicas do período deixa bastante clara as disputas pela representação de interesses, como mostra Sérgio Braga (2008). Se a elite social ou econômica de São Paulo (e se é que ela existe assim monolítica) não conseguia fazer vocalizar seus interesses politicamente por culpa do sistema político, por que é que setores industriais, urbanos e trabalhistas de estados como Rio Grande do Sul, Rio de Janeiro e Minas Gerais conseguiram? Todos os elementos, estruturais ou institucionais, eram iguais para todos. E assim sendo, causa estranheza que nenhuma explicação, com exceção daquela de Sampaio (1982) a que fiz referência, tenha pensado em observar a evolução da própria política formal paulista para entender o problema. 


\section{Variáveis políticas: sub-representação, ministérios e partidos políticos}

Partindo do senso comum de que os políticos de São Paulo dominaram a política nacional na República Velha e de que possuem presença visível muito intensa e em cargos relevantes na democracia de hoje, é possível traçarmos um quadro que esboça os diferentes períodos vividos no Brasil republicano. É importante chamar a atenção de que, se estiver correto afirmar que também a democracia de 1988 vem tendo presença paulista muito maior do que a de 1945 , a inserção dos políticos do maior estado brasileiro de pronto não poderia ser associada à existência ou não do regime democrático. Contudo, analiticamente faz muita diferença estar ou não sob regime democrático.

O motivo para isso é bastante elementar, embora muitas vezes esquecido: para qualquer ator político, predominar politicamente em democracias implica necessariamente submeter-se a eleições e, por isso, implica em povo. Políticos de São Paulo só podem ter grande destaque político nacional, em uma democracia, de uma entre duas maneiras: tendo destaque em cargos nomeados por pessoas eleitas ou se ganham eleições. Não basta ter uma posição social de destaque ou um poderio econômico de vulto. Afinal é preciso conquistar o eleitorado - seja o estadual para cargos federais estadualmente circunscritos (deputados e senadores), seja o eleitorado nacional para o cargo máximo do poder Executivo do país. E mais difícil ainda: no que se refere à presidência, para ganhar o eleitorado nacional, nem mesmo governar o estado de São Paulo é garantia de sucesso. Recordo o comentário feito por Hélio Jaguaribe em 1953: "a conquista do estado de São Paulo, quer pela ampliação material de seus meios de ação, quer pelo prestígio político que irá cercá-lo, lhe proporcionará condições muito favoráveis para a disputa das eleições presidenciais” (p.137). Seu comentário referia-se a Ademar de Barros, para quem governar São Paulo ou possuir 
sob seu manto o principal partido paulista jamais bastou para conquistar efetivamente o eleitorado do resto do país. Suas duas candidaturas à presidência, em 1955 e 1960, tiveram alta concentração de votos no estado e Ademar, ainda que bem votado (25\% e $18 \%$, respectivamente), não chegou a posição melhor do que último de três candidatos na primeira tentativa e penúltimo de quatro candidatos na última.

Entretanto, antes de continuar por essa vertente, pode ser que algum leitor incline-se a pôr em xeque até mesmo que o sistema político vigente entre 1945 e 1964 tenha sido propriamente uma democracia, especialmente porque a proibição de voto aos analfabetos constrangia sobremaneira o tamanho da demos e porque a ilegalidade de partidos como o Partido Comunista Brasileiro $^{13}$ retirava de cena opções populares determinantes. Sobre o tamanho do eleitorado, diz Abrúcio: “em 1930, a população votante equivalia a 5,6\% da população, que era o percentual mais elevado da Primeira República. Já em 1945 o eleitorado correspondeu a 16,19\% da população, chegando em

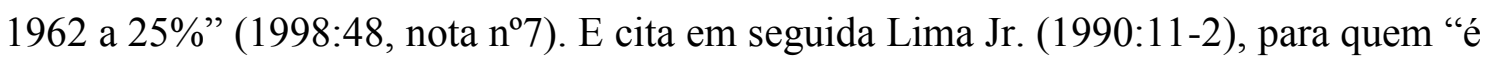
o regime de 1945 que inaugura tendências sistemáticas para o crescimento do eleitorado, em termos absolutos e como porcentagem da população total". A título de exemplo, em 2006 o eleitorado que compareceu às eleições gerais do Brasil equivalia a $67,42 \%$ da população do país ${ }^{14}$.

Portanto, se o regime de 1945 possuía uma democracia de sufrágio menos universalizado e que marginalizava alguns partidos na ilegalidade, ao mesmo tempo configurou o maior avanço democrático da história brasileira até 1988 e suas eleições eram crescentemente inclusivas. Afora isso, a despeito de considerações substantivas sobre a qualidade democrática daquele regime, não há dúvida alguma que seu

\footnotetext{
${ }^{13}$ O PCB não foi o único partido cujo registro fora cancelado durante o regime de 1946-64. A lista de registro e cancelamento partidário pode ser encontrada em Lima Jr. (1983:46-7).

${ }_{14}$ Os dados resultam da seguinte divisão: 125.913.134 de eleitores divididos por 186.770 .562 de habitantes. Números oficiais do TSE e do IBGE, respectivamente.
} 
funcionamento formal fosse típico de uma democracia ${ }^{15}$. Não quero dizer com isso que a qualidade da democracia não seja socialmente relevante, negando assim a democracia qualitativamente avaliada de Robert Dahl (1989) em detrimento de advogar a democracia minimalista de Schumperter (1961).

Ao contrário, social e concretamente a qualidade democrática importa muito. Só não pretendo entrar na discussão sobre se na democracia de 1945 os políticos brasileiros eram mais ou menos fisiológicos, mais ou menos clientelistas, mais ou menos paternalistas do que antes e do que hoje. Quero apenas dizer que, mais ou menos democrática, mais ou menos republicana, a democracia de 1945 tinha regras simples em funcionamento: por exemplo, era preciso ganhar eleições. O simples enquadramento do sistema político de 1945 como nos moldes formalistas e minimalistas de Schumpeter já é o bastante para autorizar chamar analiticamente o regime de "democracia de 194564". Afinal, se o método de seleção de líderes é eleitoral e se praticamente todo o resto do aparato institucional é democrático, os atores políticos vão ter de adotar estratégias enquadradas nessa realidade.

\section{a) Sub-representação}

Dentro dessa dimensão eleitoral, um aspecto político determinante, ainda mais em federalismos, é a questão da proporcionalidade da representação parlamentar dos estados. Não à toa, a sub-representação no Congresso configura um dos sub-temas mais recorrentes e implícitos na literatura que analisa a relação entre a política paulista e a nacional. Esse fenômeno de desproporcionalidade foi identificado por uma ampla gama de autores (BRITTO, 1965; KINZO, 1978; LAMOUNIER, 1983; REALE, 1959; SANTOS, 1987; SOARES, 1973; SOUZA, 1976; entre outros).

\footnotetext{
${ }^{15}$ Detalhes sobre as características legais da democracia de 1945 podem ser encontradas em Olavo Brasil de Lima Jr. (1983:37-41).
} 
E geralmente, foi interpretado como uma certa patologia representativa, seguindo a linha de Shugart e Taagepera (1989), primeiro trabalho a defender esse diagnóstico. Em termos simples, sub-representatividade estadual é a disparidade entre o número de cadeiras que os estados possuem e o número que deveriam possuir em caso de proporcionalidade perfeita para com sua porcentagem nacional de eleitores ou de habitantes. Sobre o assunto, segundo Kinzo, "desde que o sistema eleitoral adotado no Brasil é o da representação proporcional [...] isto, porém, tem sido desrespeitado por todas as Contituições brasileiras" (1990:37-8).

Por outro lado, há indícios na literatura de que a desproporcionalidade entre populações e cadeiras parlamentares é um expediente muito mais comum do que se imagina (para uma discussão dessa literatura, ver NEIVA, 2006; NICOLAU, 1997; STEPAN, 1999). Vários países adotam essa distorção no sentido de re-equilibrar desigualdades regionais, mas os patamares de distorção brasileiros são bastante elevados mesmo do ponto de vista comparativo. E em duas dimensões. Primeiro, efetivamente os graus de sub-representação nas democracias do Brasil são maiores do que em outras democracias (GALLAGHER, 1991; NICOLAU, 1997). E segundo, o Brasil opta pela rara fórmula de sub-representar estados na câmara baixa mesmo possuindo Senado - casa onde isso deveria ocorrer por excelência (KINZO, 1990; NEIVA, 2006; entre outros).

Por certo, a desproporcionalidade representativa dos estados, tal como mantida na Constituição de 1946, ajudava a diminuir o peso individual dos grandes estados nas decisões da esfera nacional. Dizia o texto original do artigo 58, sobre a distribuição das cadeiras na Câmara Federal: “o número de deputados será fixado por lei, em proporção que não exceda um para cada 150 mil habitantes até 20 deputados, e, além desse limite, 
um para cada 250 mil habitantes". O parágrafo $1^{\circ}$ garantia ainda o mínimo de sete representantes por estado e de um representante para cada território federal.

Ao longo da democracia de 1945, houve alterações nesse artigo, mas que não alteraram dramaticamente a situação nos pontos que nos importam aqui. De todo modo, importa reparar que: equalizado o peso dos estados no Senado (o que significa também sub-representação dos maiores) e distorcido na Câmara de modo a afetar grandes estados como Minas, Rio Grande do Sul, mas principalmente São Paulo, o poder individual de uma dessas entidades federativas de comandar o processo legislativo nacional tornava-se muito mais reduzido. Falando especificamente sobre as Câmaras Altas ao redor do mundo, Pedro Neiva explica bem essa lógica em um sentido que pode ser aplicado à compreensão da sub-representatividade de São Paulo em ambas as casas parlamentares:

\footnotetext{
tais casas legislativas [...] em vez de evitar que os estados grandes sufoquem os pequenos, como diziam os federalistas, é possível que elas funcionem no sentido de evitar que eles sufoquem a União. A [...] desproporcionalidade da representação, evita que uma coalizão de dois ou três estados ricos e/ou populosos bloqueiem as ações do governo nacional (2006:282-3).
}

Um outro leitmotiv da sub-representação paulista é apontado em trabalhos clássicos sobre a democracia de 1945, tendo os textos de Gláucio Soares $(1973,1981)$ como exemplos dos mais antigos e proeminentes. Para o autor, os paulistas e outros estados mais desenvolvidos foram sub-representados por aquela constituição, em seu artigo 58, tanto na Câmara quanto no Senado brasileiros, de modo a "aumentar artificialmente a representação política de uma cultura política tradicional atrasada, dominada pelos líderes", que havia nas áreas "subdesenvolvidas econômica, social e politicamente" (1971:7). E aí estaria parte importante da explicação para o cenário crítico de embate entre o Legislativo conservador e o Executivo reformador de que já 
falava Celso Furtado (2007). Afinal, a sub-representação dos estados desenvolvidos dava força aos conservadores no Congresso, enquanto em relação às eleições do poder Executivo, por serem majoritárias, os eleitores urbanos pesariam muito mais (SOARES, $1974)^{16}$.

Todavia, para Campello de Souza (1976:125), “cumpre indagar, porém, que efeitos teriam sido visados pelos constituintes de 1946. A que grupos pretendiam ou pensavam beneficiar? A quem beneficiariam de fato?". Para ela, os estados subrepresentados "detiveram entre setenta e oitenta por cento do eleitorado nacional durante todo o período, desde 1945 [...] força eleitoral conjunta mais do que suficiente, como é óbvio, para impedir ou emendar o dispositivo a que estamos nos referindo" (p.126). Seu livro é o primeiro trabalho a apontar uma resposta empiricamente verificada. Durante a Assembléia Constituinte de 1946, foi à votação o projeto de emenda 1.745, que tentava alterar o artigo 58 e corrigir grande parte da subrepresentação legislativa anteriormente proposta.

E segundo Campello, dos deputados que o subscreveram apenas as bancadas de São Paulo e Minas Gerais foram inequivocamente favoráveis a essa alteração. Diversos outros estados, mesmo prejudicados pela desproporcionalidade, tiveram suas bancadas ou majoritariamente contrárias, ou ausentes ${ }^{17}$. Para ela, a explicação estaria em uma associação "à oligarquia dos estados menos desenvolvidos, por isso mesmo voltada para o centralismo autoritário, contra a oligarquia dos dois maiores estados” (p.133). Ou seja, abriram mão de força legislativa para evitar repetir-se agora no Legislativo a política do "café-com-leite" que durante a República Velha dominou o Executivo nacional. Nas

\footnotetext{
${ }^{16}$ Também vem daí a interpretação de Soares sobre a reação conservadora presente no golpe de 1964: conservadores teriam perdido primeiro o Executivo, por causa dos eleitores urbanos que votavam nas esquerdas e nos populismos. E depois, estariam começando a perder o Legislativo, dada a expansão da urbanização pelo país e a melhoria da proporcionalidade de representação dos estados urbanos subrepresentados na Câmara.

${ }^{17}$ Ausência que, para a autora, significava nesse caso quase o mesmo que votar contra, dado o debate intenso e a sabida divisão de votos sobre a matéria.
} 
palavras de Abrúcio (1998:51), essa distorção já existia desde o Império, mas na democratização pós-Estado Novo "ganhou contorno próprio [...]: o medo dos estados mais pobres de haver um retorno da hegemonia paulista".

Analisar se a intenção, mesmo sendo essa, conseguiu atingir seus objetivos, é tarefa fugidia demais. Até porque, não há motivos para crer que as bancadas de cada estado tivessem unidade sólida, rachadas que estavam por clivagens partidárias muito díspares. É bastante discutível imaginar a atuação em bloco, conjunta e fechada, de bancadas estaduais. Não faz sentido nem do ponto de vista teórico e nem possui respaldo em estudos empíricos que investigaram as bancadas da atual democracia (ARRETCHE, 2007). Ao mesmo tempo, será que esse mecanismo se encontra entre àqueles que contribuíram para esvaziar o espaço de domínio possível de São Paulo, como os vários outros fatores que rapidamente listei no capítulo anterior?

Ou seja, do ponto de vista lógico, ainda que a sub-representação diminua o espaço de todos os estados e, portanto e principalmente, de São Paulo, isso não explicaria porque os políticos paulistas teriam estado em prejuízo de seus contemporâneos por exemplo mineiros, gaúchos ou cariocas. A seguinte afirmação de Campello de Souza (1977:80) nesse ponto carece de comprovação ou mesmo de sentido: “a sub-representação eleitoral de São Paulo já de si constituiria poderoso fator de atrofia à estruturação partidária do Estado”. Obviamente, o estado de São Paulo estar sub-representado no Congresso não explica por que ali os partidos nacionais não se desenvolveram. Ou porque as lideranças paulistas eram enfraquecidas nacionalmente.

Empiricamente, isso se torna ainda mais taxativo. Primeiro, comparando a quanto por cento das cadeiras na Câmara Federal correspondia a bancada paulista total, encontrei que correspondeu em média a 13,4\% entre 1945 e 1964; e a 13\% desde 1988. Exatamente o mesmo peso. Ou seja, não há diferença nesse quesito entre a democracia 
anterior e a democracia atual. E, no entanto, não se diz haver uma enorme distância da inserção nacional dos políticos de São Paulo e da força no estado dos principais partidos do país, entre esses dois períodos? Se elaborarmos um pouco mais os dados dessa discussão, analisando propriamente quanto a representação do estado ficava próxima ou distante do tamanho de sua população, fica ainda mais evidente que a sub-representação legislativa de São Paulo não consegue explicar esse ocaso político relativo aos outros estados. Vejamos o gráfico 5:

Gráfico 5 - Distorção Representativa por Anos Selecionados - São Paulo (1872-1994)

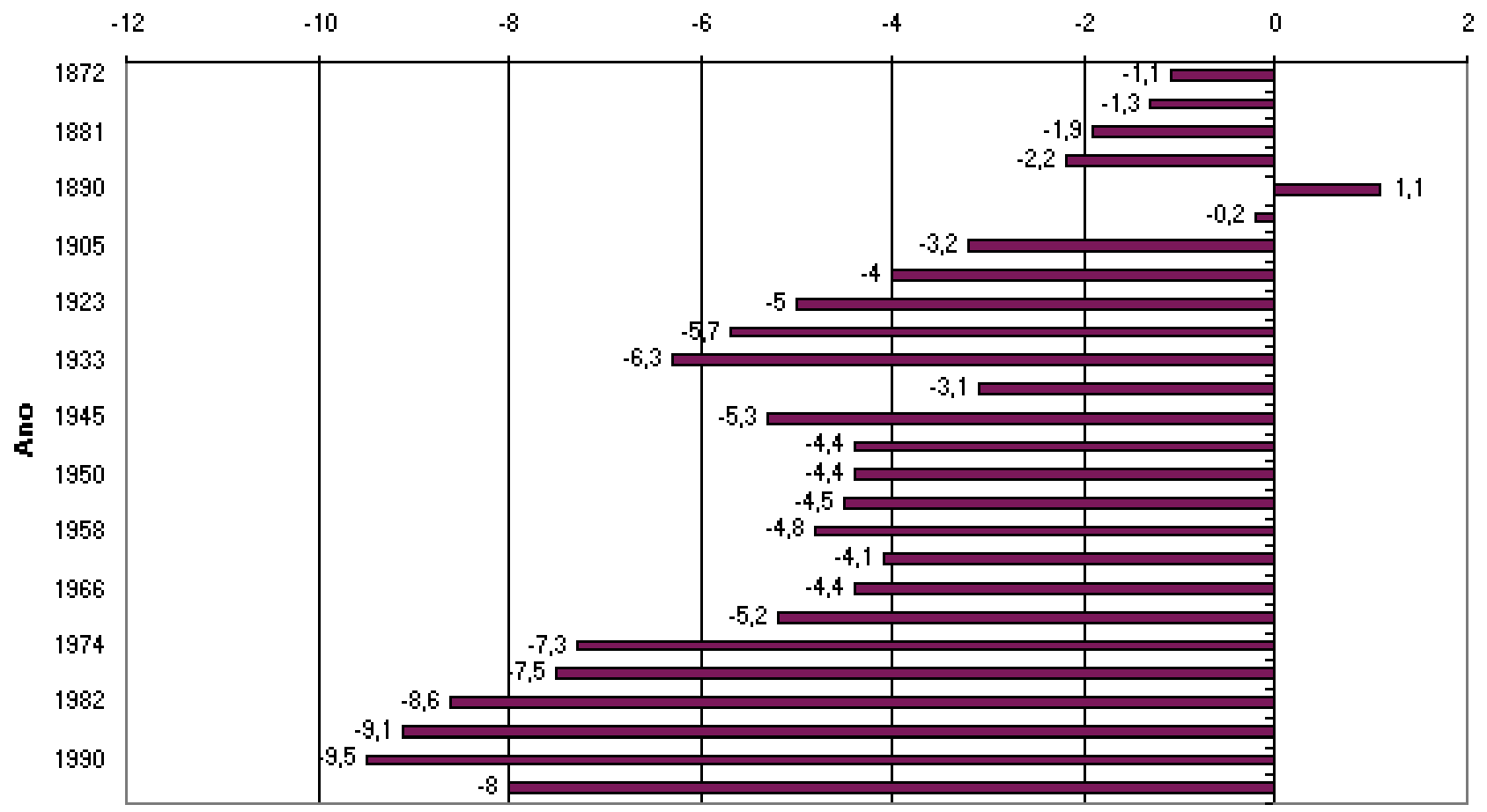

Fonte: Nicolau (1997).

O gráfico foi retirado do artigo lapidar de Jairo Nicolau (1997) sobre o problema da distorção da representação política dos estados brasileiros. Apresenta a porcentagem de cadeiras recebidas por São Paulo, a menos ou a mais do que deveria de acordo com 
sua população no ano respectivo. Não há grandes alterações após 1994, motivo pelo qual optei por não alterar o gráfico original atualizando-o. O resultado é bem claro: o nível da sub-representação paulista na democracia anterior foi sempre cerca de metade do atual. E os dados atualizados para depois de 1994 manteriam o padrão.

É interessante reparar, ainda, que a partir do governo Campos Salles (1898 a 1902), quando surge a política dos governadores que logra manter afastados da presidência os militares, a República Velha também distorceu o peso paulista na Câmara Federal em níveis que, em média, não diferiam daqueles acusados pela democracia de 1945. É claro que na primeira república brasileira, por não haver sequer o funcionamento formal de uma democracia operando efetivamente, o significado de um estado estar sub-representado poderia não ser exatamente o mesmo. Mas ainda assim, é interessante reparar a dissociação entre a distorção representativa paulista e os períodos de maior sucesso político dos representantes do estado de São Paulo.

Seria incauto deixar de comentar, ainda, uma interpretação sobre os efeitos da sub-representação paulista que é bastante usual, mas poucas vezes explicitada. Novamente, Maria do Carmo Campello de Souza é quem diz que "dentro dos estados maiores, os maiores interessados na representação exatamente proporcional seriam fatalmente aqueles interessados a sério em alguma representação, vale dizer, os grupos 'progressistas' e anti-oligárquicos” (1976:127). Ou seja, o respeito estrito à proporcionalidade dos grandes estados - e nesse assunto leia-se, basicamente, São Paulo - ao aumentar a magnitude eleitoral elevava, por conseqüência, as chances de novos atores conseguirem vagas representativas.

Continua a autora, para quem, nesse sentido, "a doação de poder legislativo aos estados menores nada mais seria do que uma convocação, por parte das oligarquias dos estados maiores, aos seus aliados nos estados menores, a fim de combaterem o inimigo 
comum: os setores emergentes dos grandes centros urbanos e industrializados" (ibidem). Ainda que sem citar a autora, Abrúcio concorda que a sub-representação "não foi de todo ruim para São Paulo. Apesar de São Paulo ter votado majoritariamente [...] contra o projeto aprovado, para boa parte da elite paulista a distorção representativa evitaria o fortalecimento dos setores politicamente emergentes dos grandes centro urbanos e industrializados" (1976:51).

Não descarto que esse resultado tenha acontecido. É possível, afinal são amplamente conhecidas as evidências de que, quanto maior o número de cadeiras de um dado distrito eleitoral, maior a probabilidade de que grupos menores e insurgentes consigam um lugar no parlamento - com a conseqüente fragmentação partidária no distrito. Contudo, julgar que essa situação tenha sido intencional, ou seja, que as bancadas paulistas tenham optado ou aceito sua sub-representação, parece um pouco de exagero. Primeiro, isso implicaria supor uma previsibilidade excessiva da força eleitoral dos setores urbanos, além de pressupor a clássica e discutível vinculação direta entre urbanização e representantes progressistas. Mas em segundo lugar e mais importante: ora, não fora exatamente a bancada paulista a única, ao lado de parte de Minas Gerais, a posteriormente votar massivamente contra a sub-representação, segundo a própria autora?

Pode-se dizer que seja correto afirmar que as intenções mobilizadas para impedir os paulistas de predominarem sobre a nação ganharam o reforço da sub-representação parlamentar. Em um sistema de funcionamento efetivamente democrático, diminuir o peso de uma estado faz com que seu potencial de influência direta na política seja reduzido em termos relativos não apenas aos outros estados, mas relativos também em contraste com o poder central. Contudo realmente sustento, com essa breve análise, que não se pode subsumir que esse fenômeno da sub-representação legislativa explique por 
que a inserção da política de São Paulo era inferior à de outros estados. Ou por que hoje, ainda mais sub-representado no Legislativo, a inserção política de seus atores seja muito maior do que de outras unidades federativas do país.

b) Nomeações ministeriais

Dizer que os paulistas sequer tenham tido peso político menor do que deveriam ou do que seria de se esperar, além de ser perigosamente normativo, é por isso mesmo inverificável. E portanto poderá ser sempre igualmente defendido ou recusado. O que significa o "deveria"? Uma afirmação dessa estirpe tem de ser necessariamente comparativa, relativa. Pondo em cheque a relação entre economia, demografia, urbanização ou sub-representação e as idéias abstratas de "força política", creio que possa, agora, deter-me com mais atenção na tarefa de definir um pouco melhor essa abstração.

Um dos caminhos mais interessantes é comparar alguns dados políticos da democracia anterior com os de outros períodos. Por exemplo, qual será o perfil de ocupação dos paulistas nos ministérios naquela democracia, quando comparado com o de hoje em dia? Recordemos que Barry Ames (1986:198) afirmara: “os paulistas não estavam nem sobre nem sub-representados nas pastas ministeriais, mas as posições que eles dominavam eram as cruciais: Fazenda, Obras Públicas e o Banco do Brasil”. Mas no texto do artigo, não discrimina os números que o levaram a esse julgamento. Esse artigo bastante antigo e um tanto marginal à biografia do autor foi, de todo modo, bastante invocado para defender essa mera impressão de que os políticos paulistas não haviam sofrido prejuízo de sua penetração na política nacional (recentemente, por exemplo, por ABRÚCIO, 1998). Para verificar esse ponto, montei um banco de dados 
com nomeações ministeriais dos dois períodos democráticos ${ }^{18}$, através dos quais poderemos observar a participação dos estados nos gabinetes presidenciais, verificando as afirmações de Ames e ainda comparando-as com o referente à democracia de hoje ${ }^{19}$ :

Tabela 2 - Número total de ministérios ocupados nas duas democracias, por estado

$1945-64$

$\begin{array}{cccl} & \text { A } & \text { B } & \text { C } \\ \text { Estado média de } \\ \text { eleitores no } \\ \text { período }\end{array}$

1988-2007

$\begin{array}{cccl} & \text { A } & \text { B } & \text { C } \\ \text { Estado } & n & \% & \begin{array}{l}\% \text { média de } \\ \text { eleitores no } \\ \text { período }\end{array}\end{array}$

\begin{tabular}{|c|c|c|c|c|c|c|c|}
\hline SP & 29 & 20,86 & 20,05 & SP & 71 & 27,10 & 22,32 \\
\hline $\mathrm{RJ}^{*}$ & 22 & 15,83 & 12,64 & RJ & 33 & 12,60 & 9,62 \\
\hline$M G$ & 23 & 16,55 & 15,57 & MG & 32 & 12,21 & 11,22 \\
\hline BA & 17 & 12,23 & 6,79 & BA & 19 & 7,25 & 7,30 \\
\hline PE & 12 & 8,63 & 4,58 & $\mathrm{RS}$ & 18 & 6,87 & 6,71 \\
\hline RS & 12 & 8,63 & 8,90 & CE & 11 & 4,20 & 4,15 \\
\hline CE & 5 & 3,60 & 4,97 & PE & 10 & 3,82 & 4,68 \\
\hline Outros & 15 & 10,79 & & Outros & 61 & 23,28 & \\
\hline Indef & 4 & 2,88 & & Indef & 7 & 2,67 & \\
\hline Total & 139 & 100,00 & & Total & 255 & 97,33 & \\
\hline
\end{tabular}

Fonte: elaboração própria

* Trata-se da soma do Rio de Janeiro com o Distrito Federal (até 1960) ou com a Guanabara depois disso.

Essa tabela de número 2 mostra o número de ministros que cada estado recebeu em cada democracia. E está de acordo com a primeira parte da afirmação de Ames: realmente, não se pode dizer que, em comparação com a democracia de hoje, os paulistas estivessem sobre ou sub-representados no conjunto de ministérios brasileiros.

\footnotetext{
${ }^{18}$ Informações detalhadas sobre a construção desse banco podem ser encontradas em VASSELAI, 2009a. É importante salientar desde já que o banco inclui também ministros não partidários. Para identificar nesses casos os estados a que pertenciam, considerei em geral onde trabalhavam e residiam à época da nomeação. As principais fontes dos dados foram os arquivos da Secretaria Geral da Presidência da República e o Dicionário Histórico-Biográfico Brasileiro (FUNDAÇÃO GETÚLOIO VARGAS, 1984).

${ }^{19}$ É meu intuito poder comparar também com os ministros da República Velha. Já possuo os dados para tanto, mas até este momento tenho excessivas informações duvidosas para poder apresentar os resultados.
} 
E nem mesmo em consideração ao seu peso no eleitorado do país, como se verifica comparando a coluna $\mathrm{B}$ com a coluna $\mathrm{C}$ em cada um dos períodos. Refiz a mesma tabulação, mas considerando apenas os ministros filiados a partidos políticos, no intuito de verificar se havia alguma alteração. Mas o padrão segue o mesmo: a quantidade de ministérios especificamente partidários que São Paulo recebeu equivaleu a 20,5\% do total do país naquela democracia e a $21,5 \%$ na atual. No entanto, isso nada nos diz sobre a qualidade dos ministérios recebidos em cada período. Por isso, testemos a outra parte da sugestão clássica de Barry Ames, no que tange ao Ministério da Fazenda e ao de Viação e Obras Públicas.

E não se trata apenas de seguir o artigo em questão. A importância do Ministério da Fazenda é evidente e conhecida, em qualquer momento democrático. Afinal, está sob sua tutela as políticas econômicas macro e micro, a política industrial, a política monetária. Em relação a esse cargo em específico, os dados da tabela 3 demonstram que a interpretação de Ames é bem mais duvidosa. Ao contrário da superioridade paulista nesse ministério, afirmada por Ames, a democracia de 1945 acusou apenas 1 ministro da Fazenda paulista a mais do que Minas Gerais, o que sem dúvida não confirma exatamente um domínio de São Paulo, como afirmou. Mas é certo que os paulistas não foram alijados ou esquecidos da pasta. No entanto, ainda mais interessante é que, na comparação com a democracia em que vivemos, é possível realmente perceber que hoje há uma concentração muito maior de mandatários desse ministério oriundos de São Paulo do que anteriormente. É uma diferença importante entre as duas épocas e que mostra que, não necessariamente, um grupo social ou regional precisa aceitar capturar a burocracia em troca de fracasso na política formal. Como se vê, o sucesso dos paulistas nos últimos anos é patente: 
$1945-64$

Estado

SP

$M G$

$\mathrm{RJ}^{*}$

BA

RS

RN

Total n

5

4

3

2

2

1

17
1988-2007

Estado $\quad$ n $\quad \%$

SP

RJ

CE

17,64

11,76

11,76

5,88

100,00

Total

14

100,00

Fonte: elaboração própria

*É a soma do Rio de Janeiro com o Distrito Federal (até 1960) ou com a Guanabara depois disso.

Considerando ainda a afirmação de Ames, como teria sido a distribuição do ministério de Viação e Obras Públicas? Não é à toa que o autor dá atenção específica a essa pasta. Segundo Lúcia Hippólito (1985:76-7), esse ministério

abrangia a Marinha Mercante, conservação de nvaios, linhas de navegação (Lóide e Costeira), estradas de ferro, Departamentos de Estradas de Ferro (para construção de novas ferrovias), Departamento de Estradas de Rodagem, portos, Correios e Telégrafos, concessão para rádio e televisão, obras de saneamento, obras contra as secas.

-Dispondo de tais órgãos, o Ministério da Viação constituía-se num formidável instrumento de poder para o partido que o controlasse, por seu extraordinário potencial de empregos e pela enorme quantidade de recursos a serem alocados, atendendo a muitos interesses partidários.

O número de indicações de ministros da Viação e Obras Públicas oriundos de cada estado está na tabela 4, a seguir. Evidentemente, não pude calcular o mesmo para a democracia de hoje, uma vez que o ministério não existe mais: foi desmembrado em uma séries de outras pastas que, contudo, exercem hoje muitas funções que não existiam na época: 
Tabela 4 - Número de ministros da Viação e Obras Públicas nomeados, por estado

\begin{tabular}{lrr} 
Estado: & $\mathrm{n}$ & $\%$ \\
& & \\
$\mathrm{RJ}^{*}$ & 6 & 37,5 \\
$\mathrm{CE}$ & 2 & 12,5 \\
$\mathrm{SP}$ & 2 & 12,5 \\
$\mathrm{MG}$ & 2 & 12,5 \\
$\mathrm{RS}$ & 2 & 12,5 \\
$\mathrm{~PB}$ & 1 & 6,25 \\
Indef & 1 & 6,25 \\
Total & 16 & 100 \\
& & \\
\hline
\end{tabular}

Fonte: elaboração própria

* É a soma do Rio de Janeiro com o Distrito Federal (até 1960) ou com a Guanabara depois disso.

Definitivamente, não se pode dizer que esse resultado dê respaldo à idéia de domínio paulista descrita por Ames. Isso não quer dizer que os políticos paulistas não tinham acesso a outros cargos menores que poderiam ser de suma importância: diretorias de estatais, de conselhos nacionais, etc. Mas obviamente, é preciso algum recorte. Como essas hipóteses vêm sendo das poucas bases empíricas em que poderíamos nos basear para afirmar que a presença política de São Paulo no governo era entre 1945-64 a mesma de outras épocas, desfaz-se o chão empírico. Não é verdade que os paulistas tinham domínio, na democracia de 1945, sobre o importante ministério da Viação. E sobre o da Fazenda, ainda mais central, os paulistas tiveram naquele período a metade da presença que têm na de democracia de hoje.

Poderíamos ainda recorrer a outros dados interessantes. Vejamos por exemplo a porcentagem de ministros de cada área de governo - social, política e econômica - que os paulistas possuíram e vêm possuindo. Classifiquei cada ministério de acordo com essas 3 áreas, tentando seguir para os diversos períodos a lógica utilizada no trabalho de Meneguello (1998) para o período 1985-1998. A identificação de qual ministério 
pertence a qual área encontra-se no anexo 2, e a síntese dos resultados dessa classificação estão na seguinte tabela de número 5:

Tabela 5 - Número de ministros de cada área que são paulistas, em cada período

\begin{tabular}{|c|c|c|c|c|c|c|}
\hline & \multicolumn{2}{|c|}{ Social } & \multicolumn{2}{|c|}{ Político } & \multicolumn{2}{|c|}{ Econômico } \\
\hline & & $\%$ & $\mathrm{n}$ & $\%$ & $\mathrm{n}$ & $\%$ \\
\hline 1945-1964 & 14 & 31,11 & 6 & 18,18 & 9 & 14,75 \\
\hline $1988-2007$ & 27 & 26,73 & 19 & 35,19 & 25 & 25,00 \\
\hline
\end{tabular}

Fonte: elaboração própria

Obs: a identificação de qual ministério pertence a qual área encontra-se no anexo 2.

Esse quadro permite sintetizar algumas das disparidades importantes na participação paulista nos ministérios brasileiros durante momentos democráticos diversos. No regime inaugurado em 1988, os paulistas vêm tendo $25 \%$ de todas as nomeações feitas para áreas econômicas, $35 \%$ das feitas para a área política e $27 \%$ da social. Em nenhuma delas há algum estado com porcentagem maior que a de São Paulo. Enquanto isso, na democracia de 1945 esse cenário acontece apenas no que se refere aos ministérios sociais: os paulistas tiveram $31 \%$ dessas nomeações e nessa área nenhum estado o superou. Tiveram, todavia, apenas $18 \%$ das nomeações para cargos da área política, no que foram superados pelos mineiros $(21 \%)$. E em relação às pastas da área econômica, obtiveram cerca de $15 \%$ das indicações, sendo superados por mineiros $(18 \%)$ e por pernambucanos $(16,4 \%)$.

c) desempenho dos paulistas nas eleições

Se os ministérios constituem um ponto inevitável para a análise, pela importância da burocracia estatal e da composição multi-regional que esses cargos 
permitem, é certo que os desempenhos eleitorais nos poderes Executivo e Legislativo ${ }^{20}$ são ainda mais centrais. Há portanto outros fatores importantes a serem considerados no estudo da presença política paulista em regime democrático, dentro da lógica eleitoral de que falávamos há pouco. Maria D’Alva Gil Kinzo coloca bem essa necessidade, dizendo que esses fatores:

têm a ver, obviamente, com a participação do Estado no poder nacional, seja através da eleição de um paulista para a Presidência da República, seja através da sua participação no Congresso Nacional (1990:37)

Comecemos pelo desempenho dos políticos paulistas em eleições para o Executivo do país. Em seguida, abordarei a situação do Legislativo federal. Creio que haja basicamente 2 tipos de informações centrais para avaliar a inserção dos políticos paulistas na disputa pela presidência da República de uma perspectiva comparativa entre os regimes políticos brasileiros. Por um lado, no que tange ao desempenho dos paulistas no nível nacional, trata-se de avaliar a quantidade de candidaturas à presidência representadas por políticos paulistas. E por outro lado, avaliar o peso, em votos, que os paulistas tiveram em cada período. Não creio ser correto considerar a República Velha para fins de comparação dos dados eleitorais, já que os resultados daquele sistema político eram pouco confiáveis dadas as fraudes eleitorais e a manipulação de resultados através da Comissão de Verificação de Poderes (ver ABRÚCIO, 1998; CARONE, 1988, 2001; CARVALHO, 1980; LEAL, 1948; FAUSTO, 1986; entre outros). Não era um período democrático quanto ao funcionamento efetivo do sistema político. E especialmente, as candidaturas paulistas

\footnotetext{
${ }^{20}$ Análises sobre o poder Judiciário aumentariam demasiadamente o escopo deste trabalho. Mas posso desaconselhar desde já que se imagine algo próximo à afirmação contida no editorial do Estadão citado por Campello de Souza (1977:78), para quem paulistas foram "completamente excluídos de um dos poderes da República, pois no Supremo Tribunal Federal, a esta hora, não há um único juiz de São Paulo". A média de ministros paulistas nomeados para o STF foi de 16,2\% na República Velha, 15,8\% de 1930 a 1945, 18,7\% na democracia de 1945, 15,6\% na ditadura instaurada em 1964 e de 20\% de Sarney até 2008. Pouquíssima variação, portanto, entre as diferentes periodizações históricas.
} 
passaram a ser, dentro da lógica do café-com-leite, pré-determinadas pela situação como a candidatura que se esperaria ser vitoriosa em eleições alternadas.

No que se refere ao desempenho dos candidatos presidenciais em São Paulo na democracia de 1945, é verdade que "os paulistas não conseguiram viabilizar nenhum Presidente da República, exceção feita à figura desterritorizalizada de Jânio Quadros" (BARBOZA FILHO, 1995:118). Mas qualquer suposta fraqueza política do estado na arena nacional não necessariamente significa que as candidaturas pudessem negligenciar o numericamente grandioso eleitorado paulistas mais do que podem hoje ou que tivessem mal desempenho nele. É preciso verificar isso, afinal o estado de São Paulo sempre correspondeu, como vimos no gráfico 2, a cerca de 20 a 25\% do nacional, desde 1945. Alguns cálculos bastante simples ajudam a examinar esse ponto.

Primeiro, vejamos: as candidaturas vitoriosas nos pleitos presidenciais dependiam dos votos obtidos em São Paulo? Ou seja, se esses votos fossem para a candidatura que ficou em segundo lugar, o resultado seria alterado ou mantido? Evidentemente, até mesmo por hipótese é um contrassenso imaginar que $100 \%$ dos votos auferidos no estado abandonassem uma candidatura e, pior, migrassem todos em bloco para o segundo colocado. Por isso, calculei em diferentes patamares o que aconteceria se os votos de primeiro turno eleitoral obtidos em São Paulo pela candidatura vitoriosa à presidência migrassem para a concorrente direta. Comecei calculando a migração de $100 \%$ dos votos em São Paulo, depois fui descendo de 10 em 10 pontos percentuais. A tabela número 6 , a seguir, indica a partir de quais patamares as eleições teriam seus resultados alterados, com a vitória do segundo colocado. 
Tabela 6 - Porcentagem de votos em SP que precisariam migrar do $1^{\circ}$ colocado para $02^{\circ}$ nas eleições presidenciais para que o resultado final do pleito fosse alterado

\begin{tabular}{rrrrrrrrr}
\hline 1945 & 1950 & 1955 & 1960 & 1989 & 1994 & 1998 & 2002 & 2006 \\
& & & & & & & & \\
$80 \%$ & $90 \%$ & $100 \%$ & $60 \%$ & $100 \%$ & $100 \%$ & $80 \%$ & $100 \%$ & $50 \%$
\end{tabular}

* Obs: para calcular a média do período atual, considerei as porcentagens dos anos 1989 e 2002 como se fossem $100 \%$, afinal sendo null não poderiam computar a média e a deflacionariam para $77 \%$.

Ora, é claro que ganhar eleições majoritárias implica em lutar por votos em todos os estados, em nacionalizar candidaturas. Maria do Carmo Campello de Souza (1976) desfez pela primeira vez, por exemplo, a clássica suposição de que os presidentes brasileiros baseariam seus votos no crescente mundo urbano, dando as costas ao eleitorado rural $^{21}$. Mesmo assim, os dados dessa tabela exigem alguma relativização da suposição de que as candidaturas à presidência do Brasil vêm tendo notável dependência dos votos recebidos em São Paulo. Na democracia atual, em média, se até $86 \%$ dos votos do candidato vitorioso junto ao eleitorado paulista migrassem para seu principal concorrente, ceteris paribus, o resultado não mudaria. $\mathrm{Na}$ democracia de 1945, não mudaria com a migração de até $83 \%$ dos votos recebidos em São Paulo. Falar em patamares altos ou baixos exigira uma pesquisa comparativa. Mesmo assim, pode-se vislumbrar, em primeiro lugar, que o eleitorado paulista era importante, por óbvio, mas não tão determinante. Ainda que apenas dois candidatos vitoriosos à presidência tenham sido derrotados em São Paulo: Juscelino Kubitschek em 1955 e Lula em 2006. Mais importante, porém: os patamares são similares em ambos os períodos. Não se poder dizer que na democracia anterior, por exemplo, os candidatos à presidência dependessem mais ou menos de votos em São Paulo do que o fazem hoje. E

\footnotetext{
${ }^{21}$ Esse era o pressuposto elementar de Gláucio Soares (1973, 1981) e Celso Furtado (1965), por exemplo, para a sugestão de oposição entre Executivo progressista e Legislativo conservador. Afinal, os congressistas seriam escolhidos por um sistema que inflaria sobremaneira a atuação de estados atrasados.
} 
dependiam, julgo, significativamente pouco. Anote-se ainda, para fins de análise posterior, que apenas em 1960 o vitorioso Jânio Quadros tem dependência de votos em São Paulo bem maior do que a média do período.

Já no sentido inverso, o que ocorria com as forças políticas que os paulistas ofereciam para as candidaturas presidenciais? Temos abaixo, no conjunto de tabelas de número 7, dados comparativos relevantes. Primeiro, é preciso saber se para a presidência da República havia e há grande número de candidatos paulistas. Afinal, como lembra Schumpeter (1961), a democracia liberal tem um importante limitador à vontade do eleitor: ele só pode votar em um leque muitíssimo restrito de candidatos previamente apresentados pelos partidos. Em suas palavras (p:344):

Os eleitores não decidem casos. Tampouco escolhem com independência, entre a população elegível, os membros do parlamento. Em todos os casos, a iniciativa depende do candidato que se apresenta à eleição e do apoio que possa despertar. Os eleitores se limitam a aceitar essa candidatura de preferência a outras, ou a recusar-se a sufragá-la.

Tabela 7.1 - Candidaturas e candidatos diferentes oriundos de SP no conjunto de eleições presidenciais de 2 períodos democráticos

\begin{tabular}{llll}
$\begin{array}{l}1945-1960 \\
\text { Candidaturas totais }\end{array}$ & $\begin{array}{l}\text { Candidatos } \\
\text { diferentes }\end{array}$ & $\begin{array}{l}1989-2006 \\
\text { Candidaturas totais }\end{array}$ & $\begin{array}{l}\text { Candidatos } \\
\text { diferentes }\end{array}$ \\
$3(20 \%)$ & $2(15,38 \%)$ & $16(61,53 \%)$ & $11(57,89 \%)$ \\
média de 0,75 por & $\begin{array}{l}\text { média de } 0,5 \text { por } \\
\text { eleição }\end{array}$ & $\begin{array}{l}\text { média de } 3,2 \text { por } \\
\text { eleição }\end{array}$ & $\begin{array}{l}\text { média de 2,2 por } \\
\text { eleição }\end{array}$ \\
\hline
\end{tabular}

OBS: foram considerados apenas os candidatos que atingiram ao menos $1 \%$ dos votos nacionais

Tabela 7.2 - Porcentagem de votos nacionais recebidos por candidatos paulistas em cada eleição presidencial

\begin{tabular}{ccccccccc}
\hline 1945 & 1950 & 1955 & 1960 & 1989 & 1994 & 1998 & 2002 & 2006 \\
$\begin{array}{c}\text { Sequer } \\
\text { houve } \\
\text { candidato }\end{array}$ & $\begin{array}{c}\text { Sequer } \\
\text { houve } \\
\text { candidato }\end{array}$ & 25,77 & 67,06 & 47,14 & 93,08 & 86,91 & 69,64 & 90,24 \\
\hline
\end{tabular}

OBS: foram considerados apenas os candidatos que atingiram ao menos $1 \%$ dos votos nacionais 
Tabela 7.3 - Porcentagem média dos votos nacionais recebidos por candidaturas paulistas em cada período

$1945-1960$

$1989-2006$

$23,21 \%$

$77,4 \%$

OBS: foram considerados apenas os candidatos que atingiram ao menos $1 \%$ dos votos nacionais

Desse modo, a seleção do plantel de postulantes já pré-determina os caminhos pelos quais os eleitores poderão movimentar-se. Em relação à apresentação de candidaturas paulistas, durante a democracia anterior $20 \%$ das candidaturas à presidência apresentadas eram de políticos paulistas, segundo a tabela 7.1. Na atual, foram até agora $61,5 \%$. Desconsiderando as vezes em que um mesmo candidato da política de São Paulo repete sua candidatura, como é por exemplo o caso de Lula, os dados só ficam mais chamativos: foram apenas duas candidaturas diferentes naquele período: Adhemar de Barros e Jânio Quadros. O que significou 15\% dos diferentes candidatos que pleitearam a presidência. De 1989 até 2006, 57,9\% foram paulistas diversos: 11 no total. As médias atingidas foram de: 0,5 candidatos paulistas nãorepetidos por eleição, ou ainda 1 a cada duas eleições, antes de 1964, contra 2,2 por eleição no pós-1989. Quase 4,5 vezes mais.

Ao mesmo tempo, os resultados eleitorais dessas candidaturas não deixam dúvidas: o estado de São Paulo gerou candidaturas muito mais competitivas recentemente do que fazia na primeira experiência democrática do país. Para se ter uma idéia, de 1945 a 1964 houve 4 eleições presidenciais e nas duas primeiras, ou seja em metade delas, sequer houve candidatos de São Paulo. Nas outras duas, o percentual total de votos que obtiveram juntos foi de 25,8\% em 1955 e de $67 \%$ em 1960 (incluindo aqui a candidatura vitoriosa de Jânio Quadros). Enquanto de 1989 a 2006, os percentuais 
foram sempre muito mais elevados, com média de $77 \%$ dos votos, contra $23 \%$ médios na outra democracia. A política paulista gerava muito menos quadros políticos para o nível de disputa presidencial do que acontece, por exemplo, atualmente. E seus quadros atraíam muito menos votos nacionais do que vêm fazendo no regime recente.

Contudo, em ambos os sistemas políticos havia eleições para 3 cargos de nível federal. Para a presidência e para as duas casas do Congresso. Evidentemente, como o número de parlamentares por estado era fixo para cada uma delas, não faria sentido uma análise para o Legislativo semelhante a essa que propus para o Executivo. Por outro lado, o estudo mais aprofundado dos resultados eleitorais nos pleitos para deputado federal em São Paulo pode trazer um esclarecimento adicional interessante. E com isso pode recolocar-nos no rumo do argumento iniciado lá atrás. Refiro-me à idéia de que, em São Paulo, os partidos nacionais não teriam penetrado: essa sim pode ser avançada através da consideração do desempenho das três grandes legendas nacionais entre os eleitores paulistas mesmo no que se refere à Câmara Federal.

Do ponto de vista da formação interna das mesas da Câmara nas duas democracias, é notável a semelhança entre as duas democracias: entre 1945 e 1964, 12 entre $20(60 \%)$ presidentes da Câmara foram paulistas, sendo 7 de $13(54 \%)$ de 1988 até o mandato 2009/2010. Na vice-presidência da casa, apenas 1 paulista assumiu o cargo em cada período. Quanto à primeira secretaria, nenhum paulista foi eleito para tal cargo no regime anterior e apenas 1 no período atual. Quadro semelhante desenha-se para os outros cargos da mesa ${ }^{22}$.

\footnotetext{
${ }^{22}$ Apesar de estar coletando dados referentes à comissões internas da Câmara nas duas democracias, ainda não pude concluir esse banco de dados. Posso adiantar, apenas, que no que tange às Comissões Parlamentares de Inquérito, a situação é semelhante nos dois períodos quanto aos autores: $14 \%$ foram de autoria de paulistas entre 1945-64 e 12\% desde 1988. Mas ligeiramente diferente quanto à presidência das comissões: $9 \%$ foram presididas por paulistas naquela democracia, enquanto $15 \%$ vêm sendo no período atual. Mas essa diferença pequena e em um cargo cuja interpretação não é tão simples quanto parece, desaconselham maiores conclusões neste momento.
} 
Já sob o ângulo que mais nos interessa aqui - o acesso eleitoral à Câmara - há dois $^{23}$ modos bastante simples e intuitivos de observar o desempenho dos partidos nesse quesito: identificar quanto suas votações em São Paulo pesaram no total de votos recebidos nacionalmente e, também, comparar o desempenho eleitoral dos partidos em São Paulo com seus desempenhos em nível nacional. Mesmo que não se trate de uma comparação da situação dos partidos políticos em São Paulo entre 1945-64 para com a situação em outros períodos, será possível avaliar com significativa clareza se é verdade e até que ponto as principais legendas tinham maior ou menor sucesso junto aos eleitores paulistas.

No primeiro caso, trata-se de observar quanto as votações no estado pesavam no total de votos obtidos por cada partido nacionalmente. Então, comparamos isso com o peso do eleitorado paulista todo sobre o eleitorado nacional todo. Se em um dado pleito o eleitorado paulista total simbolizava, por exemplo, $22 \%$ do eleitorado do Brasil, então o esperado ideal é que os partido tivessem em São Paulo também $22 \%$ dos votos que eles têm no total do país. Evidente que no mundo real e não numérico as coisas não se passam assim. Por isso calculamos quanto os votos que o partido teve em São Paulo numa dada eleição ficaram acima ou abaixo desse esperado ideal, acima ou abaixo da situação perfeita de não estar nem concentrado no estado e nem sub-presente nele ${ }^{24}$. Ou seja, se um partido qualquer estiver por exemplo $10 \%$ acima do esperado, isso significa

\footnotetext{
${ }^{23}$ Evidentemente seria possível pensar em mais caminhos. Uma outra possibilidade seria observar se os votos brancos e nulos tinham peso diferente em São Paulo, já que teriam crescido severamente em todo o país ao longo daquela democracia (LAVAREDA, 1991; LIMA Jr., 1983; SANTOS, 1986). Fiz esses cálculos, mas não achei nada digno de nota. O padrão paulista de votos inválidos e do crescimento deles foi similar ao dos outros estados. De resto, creio que essa questão foi sobre-estimada pela literatura: o único crescimento forte nesses votos deu-se em 1962. Não se pode dizer disso uma tendência e, tampouco, deve-se desconsiderar que naquele pleito introduziu-se pela primeira vez cédula única. Ora, se a recente introdução do voto eletrônico sabidamente alterou o padrão de votos válidos para cargos legislativos, por que não esperar efeito na alteração do sistema de voto em 1962?

${ }^{24}$ Matematicamente: $\left(\frac{V s p}{V b r}-\frac{E s p}{E b r}\right) / \frac{E s p}{E b r} \quad$ onde Vsp = votos do partido em SP; Vbr = votos do partido no Brasil; Esp = eleitorado paulista total; Ebr = eleitorado brasileiro total.
} 
que São Paulo pesava $10 \%$ a mais nos votos nacionais desse partido do que os paulistas em geral pesam no eleitorado nacional.

Tabela 8 - Quantos por cento os votos em SP pesaram na votação nacional de cada partido, acima ou abaixo do que o eleitorado de SP pesava no país

\begin{tabular}{rrrrrrr}
\multicolumn{2}{c}{ Câmara Federal: } & & & & & \\
& PSD & UDN & PTB & PSP & PDC & PCB \\
1945 & $-18,60 \%$ & $-23,70 \%$ & $43 \%$ & & $64,60 \%$ & $39,40 \%$ \\
1950 & $-116,30 \%$ & $-86,90 \%$ & $10,30 \%$ & $70,70 \%$ & $58 \%$ & \\
1954 & $-38,50 \%$ & $-148 \%$ & $-5,80 \%$ & $55,50 \%$ & $37,50 \%$ & \\
1958 & $-42,20 \%$ & $-98,60 \%$ & $-76,10 \%$ & $51,40 \%$ & $66,70 \%$ & \\
1962 & $-81,80 \%$ & $-133 \%$ & $-124,50 \%$ & $69,10 \%$ & $64,20 \%$ & \\
& & & & & & \\
Média & $-\mathbf{5 9 , 5 0 \%}$ & $-\mathbf{9 8 , 1 0 \%}$ & $-\mathbf{3 0 , 6 0 \%}$ & $\mathbf{5 9 , 2 0 \%}$ & $\mathbf{5 8 , 2 0 \%}$ & $\mathbf{3 9 , 4 0 \%}$
\end{tabular}

Assembléias Legislativas:

\begin{tabular}{rrrrrrrr}
\multicolumn{1}{c}{ PSD } & UDN & PTB & PSP & PDC & PCB & Colig.PSD-PSP \\
1947 & $-29,4 \%$ & $-86,1 \%$ & $31,1 \%$ & $64,9 \%$ & $59,0 \%$ & $42,6 \%$ & \\
1950 & $-95,7 \%$ & $-54,2 \%$ & $1,9 \%$ & $65,2 \%$ & $64,1 \%$ & & \\
1954 & $-80,3 \%$ & $-81,4 \%$ & $-53,8 \%$ & $49,4 \%$ & $34,9 \%$ & & \\
1958 & $-234,8 \%$ & $-37,3 \%$ & $-138,8 \%$ & $42,0 \%$ & $58,5 \%$ & & \\
1962 & & $-55,2 \%$ & $-49,4 \%$ & & $23,1 \%$ & & $-22,4 \%$ \\
Média & $\mathbf{- 1 1 0 , 1 \%}$ & $-\mathbf{6 2 , 8} \%$ & $\mathbf{- 4 1 , 8 \%}$ & $\mathbf{5 5 , 4} \%$ & $\mathbf{4 7 , 9} \%$ & $\mathbf{4 2 , 6 \%}$ & $\mathbf{- 2 2 , 4 \%}$ \\
\hline
\end{tabular}

Fonte: elaboração própria

Os resultados são conclusivos. Na última linha da tabela temos os valores médios para todo o período, onde podemos notar que, como seria de se esperar, o partido regional paulista PSP teve em média 59\% de votos a mais do que deveria ter em São Paulo, caso não fosse um partido regionalmente concentrado ali. Também sem surpresas é o resultado do Partido Democrata Cristão (PDC), partido sabidamente forte 
em São Paulo e ainda mais fortalecido pela passagem de Jânio Quadros: teve em média $58 \%$ de votos a mais em São Paulo do que deveria para não ser considerado concentrado. Um dado muito interessante é que o PCB, na única eleição federal que pôde disputar, também tinha concentração eleitoral importante em São Paulo, uma vez que teve ali $38,4 \%$ a mais de votos do que seria de se supor. Agora para os fins do argumento que começo a abordar aqui, os resultados especialmente importantes são os das três primeiras colunas. O PTB, em 1945 e 1950, esteve até mais forte no estado do que o esperado. Ou seja, o eleitorado de São Paulo era em média até mais importante para o PTB do que o era para o total do país. Mas esse cenário se inverte a partir de 1955 e no total, o partido fica com uma média negativa: $30 \%$ abaixo do que seria de se supor atingir em São Paulo. Para o PSD, o número é ainda mais discrepante: -59\%. E para a UDN, então, o valor de $-98 \%$ indica que em média teve entre os eleitores paulistas quase $100 \%$ de votos a menos do que deveria ter no estado para não configurar um partido fraco ali! Os resultados para a Assembléia Legislativa do estado são semelhantes e por isso poupo o leitor de uma descrição meramente formal.

Observando-se o número de cadeiras conseguidas e não de votos, é possível chegar a um indicador intuitivo sobre essa situação. Calculei para cada partido da democracia de 1945 quanto por cento suas bancadas federais conseguidas em São Paulo representavam do total da bancada federal conseguida no país. O PSD teve em média $8,4 \%$ de deputados federais paulistas, a UDN 6,9\%, o PTB 14,9\%, enquanto o PSP, por exemplo, teve $39,8 \%$ de seus deputados federais oriundos de São Paulo. Para se ter uma idéia, de 1982 a 2006, o PSDB vem elegendo, em média, 21\% de sua bancada federal em São Paulo, o PT vem elegendo 34,7\%, o PMDB 10\% e o DEM (ex-PFL) 5,5\%.

Tal situação acarretava em outro efeito relevante para a debilidade doas grandes partidos nacionais no estado: menor influência de paulistas nos núcleos decisórios 
nacionais de PSD, UDN e PTB. Lúcia Hippólito (1985) afirma que para um membro do partido ter peso dentro do comando do PSD, era antes de mais nada necessário que tivesse força eleitoral em seu próprio estado. Mais importante ainda, Lucia Lippi de Oliveira (1973:27-8) adverte que os estados tinham pesos diferentes nas convenções nacionais do PSD. São Paulo, ao que indicam as atas, era superado por muitos estados. Isso ocorria porque os delegados eram escolhidos na proporção de um delegado para cada município onde havia seção do partido mais um delgado para cada cinco mil votos recebidos pelo PSD em um dado estado. Algo semelhante acontecia na UDN: "os representantes parlamentares [...] detêm então, maior parcela de poder dentro do partido. Um dirigente udenista sem mandato legislativo perdia muito de sua força e prestígio", ou seja, é central "a importância das bancadas federais dentro do partido" (BENEVIDES, 1981:176). E como vimos, o peso de São Paulo nas bancadas federais udenistas era bastante reduzido. O mesmo ocorria no PTB, segundo Benevides (1989) e Delgado (1989).

A segunda possibilidade investigativa, obviamente análoga, é comparar diretamente o desempenho dos partidos no país e no estado de São Paulo. A pergunta é: quanto a participação de um dado partido nos votos paulistas era próxima de sua participação nos votos nacionais? A maneira de medir isso é ainda mais intuitiva ${ }^{25}$. Trata-se de comparar a porcentagem de votos em São Paulo com a porcentagem de votos no todo do país. Vejamos o que nos diz a tabela número 9:

\footnotetext{
${ }^{25}$ Matematicamente: $\left(\frac{V s p}{E s p}-\frac{V b r}{E b r}\right) / \frac{V b r}{E b r} \quad$ onde Vsp = votos do partido em SP; Vbr = votos do partido
} no Brasil; Esp = eleitorado paulista total; Ebr = eleitorado brasileiro total. 
Tabela 9 - Quanto a participação nos votos de um partido em SP esteve acima ou abaixo de sua participação nos votos nacionais? - CDF e AL

\begin{tabular}{|c|c|c|c|c|c|c|c|}
\hline \multicolumn{8}{|c|}{ Câmara Federal: } \\
\hline & PSD & UDN & PTB & PSP & PDC & PCB & \\
\hline 1945 & $-15,7 \%$ & $-19,2 \%$ & $75,4 \%$ & & $182,5 \%$ & $65,0 \%$ & \\
\hline 1950 & $-53,8 \%$ & $-46,5 \%$ & $11,5 \%$ & $241,4 \%$ & $137,8 \%$ & & \\
\hline 1954 & $-27,8 \%$ & $-59,7 \%$ & $-5,5 \%$ & $124,9 \%$ & $60,1 \%$ & & \\
\hline 1958 & $-29,7 \%$ & $-49,7 \%$ & $-43,2 \%$ & $70,8 \%$ & $200,2 \%$ & & \\
\hline 1962 & $-45,0 \%$ & $-57,1 \%$ & $-55,4 \%$ & $223,4 \%$ & $179,4 \%$ & & \\
\hline Média & $-34,4 \%$ & $-46,4 \%$ & $-3,4 \%$ & $165,1 \%$ & $152,0 \%$ & $65,0 \%$ & \\
\hline \multicolumn{8}{|c|}{ Assembléias Legislativas: } \\
\hline & PSD & UDN & PTB & PSP & PDC & PCB & Colig.PSD-PSP \\
\hline 1947 & $-22,7 \%$ & $-46,3 \%$ & $45,2 \%$ & $185,3 \%$ & $182,5 \%$ & $74,1 \%$ & \\
\hline 1950 & $-48,9 \%$ & $-35,1 \%$ & $1,9 \%$ & $187,7 \%$ & $178,2 \%$ & & \\
\hline 1954 & $-44,5 \%$ & $-44,9 \%$ & $-35,0 \%$ & $97,8 \%$ & $53,7 \%$ & & \\
\hline 1958 & $-70,1 \%$ & $-27,1 \%$ & $-58,1 \%$ & $72,3 \%$ & $141,2 \%$ & & \\
\hline 1962 & & $-35,6 \%$ & $-33,1 \%$ & & $30,0 \%$ & & $-18,3 \%$ \\
\hline Média & $-46,6 \%$ & $-37,8 \%$ & $-15,8 \%$ & $135,8 \%$ & $117,1 \%$ & $74,1 \%$ & $-18,3 \%$ \\
\hline
\end{tabular}

Fonte: elaboração própria

Em linhas gerais, o resultado é similar. PSP e PDC, partidos sabidamente concentrados em São Paulo, realmente tiveram, em média, desempenho muito superior nesse estado do que no país como um todo: $165 \%$ a mais e $153 \%$ a mais, respectivamente. Também o $\mathrm{PCB}$, na única eleição que disputou antes de sua ilegalização, obteve desempenho $65 \%$ maior em São Paulo. E no que tange aos três principais partidos do Brasil naquele período, PSD e UDN confirmam o diagnóstico também nesse forma de medir a situação: tinham desempenho em São Paulo sempre bastante pior do que no resto do país: em média, $34 \%$ e $46 \%$ menor. Já o PTB representa um caso curioso e que merece destaque. Em média, teve desempenho apenas 3\% menor no estado do que no país, ou seja, um desempenho em São Paulo praticamente igual ao que tinha no Brasil como um todo. No entanto, esse é um 
daqueles famosos resultados médios que escondem informações. Se acompanharmos o resultado do PTB ano a ano, vemos que seu desempenho em São Paulo começa muito maior do que no resto do país, mas vai progressivamente decaindo, até se equiparar, nas penúltimas eleições, à situação de PSD e UDN. Através dessa observação de cada pleito, percebe-se que não há diferença em relação ao processo captado na tabela anterior, de número 8. A situação do PTB em São Paulo começou com uma feição muito diversa daquela com a qual encerrou a democracia de 1945. Inicialmente, o eleitorado paulista pesava na votação do partido bastante mais do que São Paulo pesava no eleitorado do país. E o desempenho do partido ali era também muito melhor nesse estado do que na média da nação. Mas ambos cenários foram se invertendo progressivamente, em uma tendência clara e sem exceções. Até serem totalmente revertidos em 1958, quando a situação eleitoral do PTB em São Paulo, no que se refere às eleições para deputados federais, igualou-se à de PSD e UDN. Novamente, os resultados para a Assembléia Legislativa estadual seguem o padrão.

As rápidas análises feitas aqui corroboram, sob diversos ângulos, a dupla afirmação de que em certa medida os políticos profissionais de São Paulo em geral não tinham penetração das forças políticas nacionais e tampouco a política estadual nacionalizava as suas forças políticas. Julgo essa afirmação retirada, como vimos, de Lima Jr. (1983), como o modo mais preciso e completo de definir a situação política paulista na democracia de 1945. A literatura política, como argumentei anteriormente, especificou raras vezes o que entendia como singularidade política paulista ou como “deprivação política” paulista na democracia de 1945. Desses esforços, vez ou outra se originaram, no máximo, afirmações tangenciais sobre a situação partidária no estado. Tentei, neste capítulo, demonstrar que em algumas dimensões importantes o sistema de partidos nacional teve desempenho realmente abaixo da média e abaixo do esperado em 
São Paulo. Os políticos do estado ascendiam pouco à política nacional em comparação, por exemplo, com a democracia atual. Em relação à República Velha do café-com-leite, ainda menos. Essa especificação que proponho permite dar conta dos dois caminhos políticos: a recepção das tendências políticas no estado de São Paulo e a exportação das forças políticas do estado para a nação.

E permite dar conta disso na dimensão necessária: a partidária. É difícil imaginar que, sistematicamente e via de regra lideranças paulistas conseguissem ascender à política nacional tal como as de outros estados se não fosse pela via partidária. Sistemas democráticos não são impermeáveis a influências nacionais individualizadas e independentes de partidos políticos, como exemplifica a meteórica carreira de Jânio Quadros. Mas torna esse tipo de via política a exceção, não a regra. Mesmo para o leitor que avalie a democracia de 1945 ou até mesmo a atual democracia como baseadas em um sistema político de tipo personalista, não deve ser difícil concordar que os principais líderes políticos de expressão nacional são aqueles que arregimentam atrás de si força partidária, ou mesmo concordar que a principal via de acesso estadual à política nacional são as legendas partidárias. Ainda que possam surgir exceções, o caminho padrão para a política do país eram os partidos políticos. A própria literatura tradicional sobre a democracia de 1945, caso não intuísse em alguma medida esse tipo de interpretação, não teria porque se impressionar com o fato de que São Paulo apresentasse um sistema partidário singular.

De qualquer modo é evidente, contudo, que a afirmação da não penetração dos partidos nacionais no estado e da não nacionalização das forças políticas estaduais, embora constitua um caminho necessário ao argumento, não pode passar de uma variável interveniente, à medida que suscita de imediato a pergunta: por que, então, isso ocorreu? Quais as causas desse padrão diverso do restante do país? Em primeiro lugar, 
não deixa de ser verdade que a capacidade de São Paulo fazer vingar nacionalmente seus quadros regionais foi fortemente prejudicada. Repito a citação porquanto seja fundamental: falando sobre os nordestinos no cenário do regime atual, a definição de Oliveira (1993:44) é excelente ponto de partida se trocarmos Nordeste de hoje por São Paulo de 1945-64: "não há qualquer grande político nacional que tenha construído sua reputação fazendo carreira no NE" ou "não há político algum do NE que consiga alçarse à condição de liderança nacional”. Em grande parte, essa era sim a situação paulista na democracia de 1945. Em segundo lugar, os partidos nacionais verdadeiramente não penetraram eleitoralmente em São Paulo tal como no resto do país.

Nos próximos capítulos, proponho começar a construir uma explicação para essa situação. Digo começar porque tenho consciência de que se trata de um esforço iniciador, que abre o assunto e não que o encerra. Pretendo analisar as diferenças que houve na formação dos partidos em São Paulo e no resto do Brasil. Creio que o varguismo, a relação deste com a política paulista e o modo como as legendas se estruturaram no país, segundo a descrição de Campello de Souza (1976), constituem uma soma de fatores que pode ajudar a entender um pouco melhor a situação. Além disso, creio que a própria interpretação da atuação das principais lideranças paulistas no período pode ser auxiliada pelo estudo da passagem de regime. A seguir, estudemos então algumas questões conceituais necessárias sobre o varguismo e sobre a relação entre os políticos paulistas e o varguismo. Para em seguida, podermos analisar os partidos políticos da democracia de 1945 e depois o caráter de suas lideranças em São Paulo, no intuito de encontrar alguma pista do que tenha havido de comum a todos para explicar o que aconteceu com tão diversos grupos políticos para que se tornassem muito menos fortes no estado do que no Brasil como um todo. 


\section{Capítulo 3}

\section{Varguismo, Estado Novo e elites paulistas}

A capacidade dos políticos de se manterem absolutamente versáteis, voláteis ao vento de seus interesses de momento, tem limites. Por certo, lembrando as categorias de Weber (2004), o político profissional é mais afeito à ética das responsabilidades do que à das convicções. Está de olho nos resultados para sua carreira e, tanto quanto possível, adapta suas táticas, seus caminhos, suas decisões, suas posturas e suas alianças, de acordo com a maximização do sucesso desses resultados. Mas apenas tanto quanto possível. O passado, ao menos o imediato, faz diferença. Também para o político profissional, suas táticas anteriores, seus caminhos percorridos até o presente, suas decisões antecedentes, suas posturas e alianças prévias, não são sempre facilmente descartáveis. Especialmente em se considerado o grupo, não a unidade: pode ser que um dado indivíduo seja extremamente volátil. Mas para um grupo inteiro de pessoas, sistematicamente, seria tão fácil assim adotar posições políticas a despeito de seu passado imediato? Freqüentemente, em política, o que se constrói hoje tem impacto amanhã. O caminho escolhido antes constrange o leque de caminhos depois.

Esse é o sentido mais genérico da idéia de que, analiticamente, a história importa (NORTH, 1990; PIERSON, 2004; SKOCPOL, 1985, 1995). Segundo Pierson (2000:252), "in the broader version, path dependency refers to the causal relevance of preceding stages in a temporal sequence". A suposição da dependência da trajetória confunde-se, nessa definição mais intuitiva, com a própria percepção de que as escolhas políticas de momento afetam futuras escolhas. Citando William Sewell, Pierson continua: "Sewell, for instance, suggests path dependence means "that what happened at 
an earlier point in time will affect the possible outcomes of a sequence of events occurring at a later point in time"' (apud PIERSON, 2000:252). Ainda que Pierson ache essa interpretação muito rasa, pouco recortada, ela serve para começarmos a atingir a questão. Mais à frente abordarei o outro significado mais estrito para a importância do passado, em que se configura propriamente dependência da trajetória (path dependency) e não apenas influência de momento anterior (outcome dependency).

Por enquanto, retendo-me ao sentido mais geral da importância da história para a compreensão dos desdobramentos políticos, é interessante perceber que muitas das mais ricas explicações sobre diversas passagens da história política brasileira acabam dando conta da importância do passado sobre a construção do "presente". E isso, independentemente de partirem ou não de um paradigma declarado de valorização analítica da história. O livro fundamental de Maria do Carmo Campello de Souza (1976) como um exemplo de monta. Para a autora, a explicação mais profunda para o desenvolvimento das forças políticas da democracia de 1945 residiria nas suas heranças do Estado Novo. Heranças de uma mentalidade anti-liberal, pouco democrática, mas principalmente heranças de clivagens políticas anteriores e de um sistema partidário constituídos sob a máquina de governo Varguista. É amplamente conhecida na literatura a idéia de Campello, para quem os principais partidos governistas, PSD e PTB, nasciam fortalecidos por essa ligação umbilical com o Estado Novo $^{26}$. Se é verdade que "Getúlio criou o Partido Social Democrático com a mão direita e o Partido Trabalhista Brasileiro com a mão esquerda" (BENEVIDES, 1989:31), fez isso porque criou o primeiro a partir das interventorias estaduais, dominadas pelos acordos com oligarquias, e porque criou o

\footnotetext{
${ }^{26}$ A interpretação que Regina Sampaio (1982) faz dessa idéia de Campello de Souza (1976) sobre a formação dos partidos ajuda a resumir esquematicamente as implicações do raciocínio: o peso do Estado como herança seria inversamente proporcional ao peso da institucionalização dos partidos. Ainda assim, ressalvo que Campello não via o sistema partidário como natimorto: o peso estatal na formação de PSD e PTB prejudicava institucionalização própria do sistema, mas o desenrolar da democracia de 1945 estaria apontando exatamente para uma crescente diferenciação entre partidos e o Estado.
} 
segundo a partir da estrutura do Ministério do Trabalho que cooptava os sindicatos. Nas palavras da autora (p.98), Vargas buscava através do PTB absorver "as clientelas urbanas sindicalizadas ou cobertas pelas instituições previdenciárias" e com o PSD "as interventorias e bases municipais". Também as clivagens políticas teriam perpassado a mudança de regime: muito esquematicamente, sabe-se que o PSD congregava a oligarquia que era próxima de Vargas e também varguistas mais conservadores em geral. O PTB arregimentava setores urbanos e varguistas mais progressistas. A UDN concentrava os antípodas de Getúlio.

Mas a propósito de mudanças de regimes - questão central para meus argumentos neste trabalho - há ainda outros exemplos importantes de estudos que consideram a influência do passado político. Como mencionei no capítulo inicial, nesse tema em específico centro minha inspiração na tese de doutoramento de Eduardo Kugelmas (1986). Trabalho nunca publicado, essa tese descreve os processos políticos pelos quais a política paulista protagonizou a passagem do Império para a República e, daí, passou a predominar sobre a política nacional. Apenas recapitulando: para o autor, os paulistas miravam antes hegemonizar sobre seu próprio estado e, na busca pelo regime político que lhes permitissem fazê-lo, acabam incidentalmente construindo um regime que lhes permitiu muito mais. Creio que uma interpretação possível ao trabalho de Kugelmas poderia reter o seguinte aspecto: sua descrição da "difícil hegemonia paulista" acaba revelando que o sobre-poder paulista na República Velha era, em muito, uma decorrência de terem sido os paulistas os construtores principais daquele novo momento histórico. Foram os artífices do regime Republicano. Pouco importa se miravam - como sugere o próprio Kugelmas, e também Schwartzman (1975), Love (1982) e muitos outros - antes o federalismo do que a República. 
Partindo de análises como essas, seria profícuo aplicar esses raciocínios na interpretação da formação da nova política paulista na passagem de regime em 1945. A pergunta, mais específica, seria: como se deu em São Paulo a montagem da nova democracia tal como descrita por Campello de Souza (1976) considerando-se, em uma expansão da trilha analítica de Kugelmas (1986), a singular relação da política paulista com a ditadura de Vargas por terem sido os paulistas politicamente "derrotados" naquele regime? Através dessa indagação, sugiro a congruência de três elementos complementares entre si. Primeiro, como diz Campello de Souza, a formação dos principais partidos políticos brasileiros, na democracia de 1945, foi marcada pela ligação de seus membros com a máquina de governo de Getúlio (SOUZA, 1976). Em segundo lugar, porém, a ligação da elite paulista com Vargas tinha um histórico sabidamente muito particular - ainda que isso seja pouco lembrado dentro desse tema. E em terceiro lugar, é preciso passar rapidamente pela discussão sobre o significado e a extensão da idéia de varguismo que adoto aqui - uma idéia que propositalmente não avançarei na definição, abordando-a de modo não substantivo, mas ssim como o pivô em torno do qual se configuram as clivagens políticas até depois da morte de Getúlio se considerarmos o varguismo enquanto projeto mais amplo do que a prática política de um indivíduo.

Começo pelo final, ou seja, elaborando um pouco melhor o papel e a continuidade do varguismo. Depois, avanço para a relação entre as sempre genéricas elites paulistas e esse varguismo. Por fim, deixo para o capítulo seguinte a tarefa de adentrar com mais cuidado em como teriam os principais partidos políticos se formado e se desenvolvido em São Paulo - ou seja, como as especificidades do processo descrito por Campello de Souza no estado explicam as questões desta pesquisa. 


\section{Extensão e significado do varguismo}

Gláucio Soares (1973) foi um dos principais autores a apontar que o golpe que derrubou Vargas em 1945 não trouxe nenhuma alteração sócio-econômica, mas apenas política. E mesmo assim restrita: por um lado, não modificou as bases de sustentação do regime nos mesmos grupos sociais e, por outro, politicamente não fez mais do que retirar do poder Getúlio e sua equipe mais próxima. Permitiu-se até mesmo que Vargas fosse candidato, ganhasse e assumisse um mandato parlamentar. De fato, o fenômeno foi captado por célebres críticos do ditador, como se vê no diagnóstico da revista Anhembi: "[a Getúlio] salvou-o o erro de não lhe cessarem os direitos políticos e permitirem que concorresse aos postos-chave da defesa da democracia" (ANHEMBI, 1950:127), de modo que "Vargas foi deposto, mas o 'estado novo', na sua essência, vive robusto, perniciosamente robusto, no parlamento, no judiciário, na administração [...]" (ibidem, p.6). Carlos Prestes, na frase famosa sobre a candidatura de Vargas à presidência em 1950, continua inconformado com o fato de que o regime construído na derrubada do ditador nada afrontara o domínio varguista: “O senhor Getúlio Vargas, senador, não deve ser candidato à presidência. Candidato, não deve ser eleito. Eleito, não deve tomar posse. Empossado, devemos recorrer à revolução para impedi-lo de governar".

De fato, a redemocratização teve não apenas seu processo de construção institucional controlado por Vargas (SOUZA, 1976), como também manteve políticos e projetos políticos alinhados ao governante. A descrição de Aspásia Camargo constitui referência excelente para essa interpretação - ainda que não seja meu interesse discutir aqui se, como ela afirma, a ditadura instaurada em 1964 também seguia em certo sentido algum modelo de varguismo. Vejamos:

La era Vargas puede dividirse en tres etapas: la primera, oficial, se inicia con la Revolución de 1930 y se cierra con su suicidio en 1954. La segunda denota 
la influencia del líder más allá de su muerte y se cierra con la deposición, en 1964, de su fiel seguidor y ex ministro de Trabajo, el presidente João Goulart. La inflencia del pacto corporativo que Vargas presidió se extiende, por lo tanto, gasta la Constitución de 1988 y las elecciones de Fernando Collor, en 1989. Por esta razón, podemos afirmar que tuvimos una era de Vargas con Vargas, una era de Vargas sin Vargas y finalmente, una era de Vargas contra Vargas [...] (1993:309)

O significado mais claro dessa duradoura "era Vargas" é dado por Bolívar Lamounier (1994:23):

Prenunciava-se claramente em 1944 o fim do Estado Novo (1937-1945), mas apenas se iniciava, na verdade, o chamado 'ciclo getulista' - se por esta expressão entendermos não apenas o período em que Getúlio exerceu diretamente o poder, mas todo o período de vigência do modelo econômico e político que nasceu sob sua liderança e inspiração.

Também para Barboza Filho, esse período teria sido tão dominante e extenso que apenas em 1994 “o governo Fernando Henrique quer, declaradamente, enterrar a era Vargas" (1995:93). Para ele, essa longa era teria sido marcada por uma série de características que ajudam bem a sintetizar as múltiplas facetas frequentemente identificadas pela literatura sobre o varguismo: o controle estatal sobre a movimentação do capital; a construção do Estado como estado-empresa; a definição do Estado como estimulador e protetor do mercado interno; a definição do Estado como regulador das relações sociais; entre outras (pp.104-5).

De certo modo, sigo nesta pesquisa essa linha interpretativa pela qual o varguismo pode ser entendido como um conjunto de projetos ou modelos de política, de economia e de organização social que perpassam a própria figura de Vargas. Considero que essa linha política influenciou e ajudou a orientar posições políticas antes da democracia de 1945, na formação desse regime e mesmo depois do suicídio de Getúlio. Suicídio que, aliás, segundo Campello de Souza (1976), teve exatamente o efeito de dar 
sobrevida à cristalização das clivagens políticas em torno dos pró-Vargas e dos antiVargas, por assim dizer, por cima dos alinhamentos puramente classistas ou mesmo da oposição progressismo versus conservadorismo.

Ou seja, meu interesse aqui não é definir "varguismo" tal como Ricardo Bielschowsky (1988) providencialmente definiu com clareza, pela primeira vez, o conceito econômico de "desenvolvimentismo". Fazer isso seria sem dúvida de grande valia, visto que essa tarefa capital até hoje está inconclusa na literatura. No entanto, fugiria sobremaneira ao escopo de minha pesquisa. E de todo modo, em verdade, proponho apenas que, a despeito do que se considere substantivamente como varguismo, fato é que esse projeto, essa era, essa linhagem de atuação política, constituiu o pivô das clivagens da política brasileira de 1930 até pelo menos 1964. Mais importante do que procurar uma semântica inequívoca para o projeto do varguismo, é perceber que esse funcionou como um pivô em torno do qual se organizou a política brasileira. Sem prejuízo de outros matizes ideológicos ou políticos, tal como esquerdadireita: não tenho interesse de argumentar contra a existência ou importância desse clássico degradê de posicionamentos. Apenas aponto que, para a questão de pesquisa que move este trabalho, é mais necessário reter o olhar, antes, sobre a conhecida clivagem em torno de Vargas do que sair à caça das clivagens de classe como se fossem as únicas legítimas e o telos da cadeia evolutiva.

É verdade, claro, que a partir da década de 1950 o combate ao comunismo daria uma nova tônica à organização das forças políticas, aos discursos e aos alinhamentos táticos dos partidos e dentro dos partidos. Benevides opina que, para ela, "o antigetulismo da UDN só seria superado pelo anticomunismo contra João Goulart - mas aí, também, 'o passado condena', pois Jango era considerado o herdeiro direto de Getúlio" (1989:31). Não é difícil entender porque o comunismo passou a influenciar as 
divisões políticas naquele momento e até mesmo ao ponto de levar à radicalização do fim da democracia de 1945, em torno das reformas de base. Ao temor com a efervescência urbana - que o dito populismo de Vargas representava - veio-se somar uma nova ameaça. O acirramento dos ânimos dos contendores da Guerra Fria, a agitação dos movimentos campesinos de inspiração socialista ou comunista na América Latina e principalmente a Revolução Cubana em 1959 provavam, com crescente e atemorizante nitidez, que o perigo não estava somente no operariado urbano. Esse é o processo captado por Amélia Cohn (1978:82), para quem “internacionalmente, as Ligas [Camponesas] tiveram grande repercussão, sobretudo porque a América Latina estava se caracterizando, no período, como uma área explosiva, especialmente a partir da Revolução Cubana".

Daí decorria que, cada vez mais, não apenas os filhos da industrialização e da urbanização, tão restrita a São Paulo no começo do período, simbolizassem a modernização da política, a implantação de uma democracia de demos expandido ou, pior, o comunismo. Também os trabalhadores do campo, os desempregados do campo e os sem-terra tornavam-se progressivamente uma ameaça real àqueles preocupados com a "esquerdização" da política nacional. A revista Life, citada também por Cohn, dizia em 1961 que o líder "Julião e os camponeses brasileiros são a combinação revolucionária potencialmente mais explosiva da América Latina [...]” (apud COHN, 1978:82). Aqueles preocupados com a esquerdização da política temiam é por uma guinada radical do PTB, e não à toa. O partido que mais encampou os ideais desses movimentos, através da defesa das Reformas de Base, foi o mesmo partido que teve o lócus de seu crescimento na democracia de 1945 exatamente no Norte-Nordeste do Brasil, tidos como centros agrários ${ }^{27}$.

\footnotetext{
${ }^{27}$ Em outro trabalho (VASSELAI, 2009b), demonstrei empiricamente, através dos resultados eleitorais para a Câmara Federal, que a ascensão do PTB foi concentrada nessas regiões, sobretudo no Nordeste.
} 
Porém, não estou exatamente de acordo que o comunismo substituísse o varguismo quanto epicentro das clivagens políticas, ainda que viesse justapor-se a ele. Com a crescente atenção dada aos movimentos de esquerda, o fantasma do comunismo mudaria a conotação do varguismo e de seus contrários no aspecto ideológico e político, mas sem necessariamente substituir-lhe a essência quanto projeto definidor das clivagens políticas. Do mesmo modo que o desenvolvimentismo de Juscelino Kubitschek era bastante diverso do nacionalismo econômico de Vargas (BIELSCHOWSKY, 1988) e isso mesmo assim não o retira por completo do espectro mais geral do varguismo, tal como falei anteriormente.

Quando a própria Maria Victoria Benevides (1978:30) define "a sedução exercida por Vargas sobre os partidos políticos durante a assim chamada democracia populista (1946-1964)" como a idéia de que "os três maiores partidos do período - e não apenas o PSD e o PTB, mas também a UDN - foram, de formas diversas, criaturas de Getúlio Vargas”, está na verdade apontando que a influência de Getúlio perpassou todo o período democrático. E o fez em um sentido cuja captação mais contundente foi feita por Bolívar Lamounier (1994:37): a "fenda que se abrira no país, e que à falta de melhor termo é aqui designada como getulismo x antigetulismo". Essa é questão central para o argumento que pretendo desenvolver. A passagem de Vargas pela política do país criou uma linha de divisão política importante na orientação dos partidos e das facções intra-partidárias. Lamounier dá sequência à questão, em uma passagem sobre o mandato democrático de Vargas que, contudo, julgo ser procedente mesmo para os anos anteriores da democracia de 1945 e também para o Estado Novo:

Por que, então [os conflitos getulistas x antigetulistas] se configuraram com tamanha virulência durante o segundo governo Vargas? Por que continuaram

Foi a penetração nos estados nordestinos que fez com que o PTB atingisse vertiginoso crescimento na democracia de 1945. Depois de preparar essa análise ainda não publicada, reparei que há citação en passant sobre esse fato em Lavareda (1991). 
fermentando mesmo após sua morte, contribuindo para o agravamento da crise de 1961-64? [...] É que se abriu nos anos 50 uma clivagem política profunda, formada por diferentes camadas sedimentares, mas tendo como eixo organizador o antagonismo entre getulismo e antigetulismo" (LAMOUNIER, 1994:44)

No entanto é claro que, se não pretendemos nenhum maniqueísmo, é preciso ter em mente que há tons gradientes nessa tipificação. Políticos podiam ser mais ou menos alinhados a Vargas, mais ou menos leais, estar mais ou menos de acordo. Não se trata de estarem com Vargas ou contra Vargas. Até porque, era o próprio Getúlio quem dizia "nunca tive inimigos com os quais não pudesse me reconciliar". Assim, penso que um modo importante de não deixar escapar os gradientes que há entre o varguista mais entusiasta e o anti-varguista mais empedernido é dar conta da existência de políticos não-varguistas. Essa distinção será muito útil mais adiante para entender a política paulista, uma vez que não será difícil perceber que as lideranças políticas surgidas em São Paulo eram, quando não anti-varguistas em estado puro, na melhor das hipóteses não-varguistas nítidos. Ou seja, políticos que a despeito de não fazerem política ostensiva a Getúlio, aos herdeiros do varguismo ou ao projeto do varguismo, estavam em geral distantes desses. Em suma, chamarei de não-varguistas esses políticos distantes o bastante da turma de Getúlio ao ponto de poderem fazer-lhe oposição, mas não adversários duros o suficiente para também, por vezes, aliarem-se a ele taticamente.

Através dessas clivagens mais gerais é que adoto a idéia de que o vulto de Vargas pairou tanto sobre o Estado Novo como sobre a democracia de 1945. Afinal de contas, não se diz que a diferença entre as oligarquias estaduais passou a ser, em geral, se estavam com ou contra a ditadura de Getúlio? E não é repetido tantas vezes, também, que a criação dos partidos obedeceu à lógica mais direta de amigos do ditador para o PTB e PSD, inimigos à UDN? Como antes da Revolução Vargas não despertava ódios 
ou paixões, pode-se dizer que essas clivagens desenvolveram-se desde a década de 1930, tomaram corpo no Estado Novo e chegaram maduras à democracia. Lembro a discussão com a qual iniciei este capítulo: por certo muitos políticos de todo o país

mudaram de lado. Foram uma hora oposição, outra hora situação. Até mesmo Oswald Aranha, braço-direito de Getúlio no Estado Novo, migrou seu posicionamento. Estou de acordo que os políticos profissionais dancem conforme a música - e aliás, não faço com isso uma crítica, como é de praxe, já que não identifico nessa afirmação nenhuma anomalia brasileira particular que timbre nossos políticos como exóticos em relação ao padrão mais universal de política profissional como sendo "results oriented".

Neste momento chamo atenção, apenas, que essa realidade de volatilidade de alinhamentos políticos não pode nublar a importância do varguismo e das relações de poder para com a ditadura de Getúlio no que se refere à formação, composição e organização das forças políticas com vistas à democratização de 1945. No que se refere à política paulista, reter essa idéia é importante para que se perceba, como pretendo começar a discorrer a seguir, as especificidades de relação dos políticos do estado com a passagem de Vargas pelo poder antes da democracia.

\section{Vargas e os paulistas no Estado Novo}

A conjunção de elementos explicativos de que falava anteriormente envolvia três idéias complementares. A primeira - formação dos partidos da democracia de 1945 a partir das heranças do Estado Novo - em linhas gerais retirei do trabalho de Campello de Souza (1976) e deixei para retomar no que se refere ao caso paulista no próximo capítulo. A outra, acabamos de tangenciar: o varguismo configurou um eixo de clivagens políticas que organizava as relações partidárias e os posicionamentos políticos no Estado Novo e em toda a democracia de 1945. Resta agora tratar do outro ponto: a 
relação entre a política paulista e o governo ditatorial de Getúlio antes e no limiar da democratização, que fez com que essa clivagem política tivesse uma face particular em São Paulo.

Em trabalho recente sobre a historiografia da política paulista sob Vargas, James Woodard (2006) espanta-se, e parece-me que com toda razão, com a falta de estudos sobre a relação entre Vargas e a oligarquia paulista, especialmente a elite política de São Paulo. É verdade que se podem encontrar muitas pesquisas sobre a situação dos industriais durante o Estado Novo, algumas descrições históricas sobre as alternâncias de apoio da "elite paulista" a Vargas dos anos trinta aos quarenta, e mais um ou outro tema correlato. Mas pouco se estuda a relação desenvolvida entre os políticos de São Paulo e o varguismo, especialmente depois do golpe de 1937.

Recentemente, a tese de doutorado de Adriano Nervo Codato (2008) foi direto a esse ponto ao realizar um belo estudo prosopográfico de elites dos membros do Departamento Administrativo do Serviço Público de São Paulo (DASP-SP) durante o Estado Novo. Como se sabe, os "daspinhos" estaduais foram a segunda face da moeda, em complemento às interventorias, pela qual a ditadura varguista controlava os governos dos estados. Codato aponta:

minhas questões principais são: o que aconteceu nesse intervalo entre a Revolução [de 1932] e a Constituição? Como foi possível desarticular as poderosas organizações políticas estaduais, trocar quase todas as lideranças políticas nacionais, federalizar as grandes questões sociais e converter a ideologia do liberalismo oligárquico em estatismo autoritário? (2008:p.2)

Considero esse trabalho uma das obras inovadoras sobre o assunto e sobre o período publicadas recentemente, quer seja porque essas perguntas apontam para agendas de pesquisa necessárias, quer seja porque declaradamente pretende estudar os políticos profissionais paulistas. Mas quanto à resposta que oferece a essas perguntas, 
uso sua tese aqui exatamente como importante avesso ao que proponho. Acontece que sma interpretação é talvez das primeiras a tornar academicamente explícita uma linha de pensamento que me parece muito difundida. E cuja aceitação incauta, julgo, deve ser evitada. Para Codato, “a presença de certos grupos da elite estadual nas estruturas do Estado ditatorial contribuiu decisivamente para sua conversão (e não simplesmente adesão) à ideologia autoritária e, por essa via, para sacramentar o processo de transformismo das "oligarquias"” (p.55). Transformismo esse que seria "um importante processo de conversão no mundo das elites políticas brasileiras” (p.3), não se tratando

“apenas, embora também, da transposição de integrantes da elite indivíduos - de um campo político (oligárquico) para outro (autoritário), mas da dominação, decapitação e assimilação das elites adversárias a fim de produzir uma nova classe dirigente: processo esse que casa com aquilo que A. Gramsci designou por "transformismo"” (p.55)

E especificamente sobre o que se passava em São Paulo, afirma:

É verdade que o transformismo da classe política não foi privilégio dos paulistas. Mas seria um tanto difícil adivinhar que depois do levante de 9 de Julho democráticos, peceístas e perrepistas estariam, apenas alguns anos mais tarde, alinhados com Vargas. Inimigos íntimos, afinal foi em São Paulo que o "getulismo" encontrou maior resistência política e ideológica antes de 1937 e depois de 1945 (basta lembrar das dificuldades para o fortalecimento dos partidos "populistas" e a penetração das idéias trabalhistas no estado), o controle político das oligarquias, a costura de novas lealdades partidárias e o processo de pacificação social parece mais compreensível [...] (p.2)

Discordo dessa linha de interpretação pois creio que o autor supõe um fenômeno político partindo de um princípio teórico discutível. Senão vejamos: o fato de um político aceitar participar da interventoria ou de um "daspinho" no Estado Novo não significava seu "transformismo" ou sua adesão ao autoritarismo, como Codato subsume. Muito menos, se transplantarmos para o tema que tratei anteriormente, significaria sua adesão ao varguismo. Tratava-se apenas de um cálculo estratégico básico: essa inserção 
no aparato da ditadura de Vargas era apenas o mais perto que os político podiam ou conseguiam chegar de exercer governo sobre os assuntos estaduais naquela circunstância, para além da custosa - e recentemente fracassada - opção de enfrentar o regime. Enfrentá-lo, naquelas circunstancias, era um ato de insurreição. E os paulistas, havia pouco, tinham sido derrotados exatamente em uma tentativa dessa natureza.

Abraçar a única opção de fazer parte da política paulista não parece significar $a$ priori uma opção pró-Estado Novo. Dito de outro modo, não era uma escolha positiva, mas sim negativa. A interpretação de Codato nos levaria a julgar esse pragmatismo político plausível como um desvio da conduta a ser esperada. Mas era possível esperar outra coisa? Ou seja, esperar que toda as elites paulistas se mantivessem fora do governo Vargas por questão de princípios? É a velha história: a política pragmática (aceitar única opção de participar do governo do estado) não pode ser vista como uma deturpação de algo que por suposto deveria ser ideológico (repulsa ao ditador; sentimento paulista). Outro exemplo desse tipo de expectativa implícita é dado pelo autor ao comentar que, dos 22 membros do "daspinho" de São Paulo entre 1937 e 1945, “apenas Miguel Reale ingressou, e permaneceu, num partido autenticamente paulista (o Partido Social Progressista, de Ademar de Barros)" (p.203). Ora, seriam autenticamente paulistas apenas partidos regionais de São Paulo? Ou apenas partidos nascidos ali? E inversamente: a ligação de políticos paulistas ao PSD ou ao PTB, quando da passagem para a democracia de 1945, bastaria para configurar vinculação ao varguismo?

Não se pode negligenciar a imprescindível recordação feita por Olavo Brasil de Lima Jr. (1983): houve na democracia pós Vargas subsistemas partidários estaduais muito discrepantes entre si tanto quanto ao desempenho político-eleitoral como quanto aos alinhamentos de suas seções estaduais. Lembro as sugestões de Hippólito (1985) de que o PSD não era um, mas vários - expressão emprestada, aliás, por Benevides (1981) 
referindo-se à UDN e por Leopoldi (1989) ao tratar do PTB. O ponto em que quero chegar é que, em São Paulo, ao contrário do que o autor supõe, ser PSD na nova democracia de 1945 não era necessariamente ser um homem de Getúlio. Assim como ter estado nas interventorias ou no daspinho antes de 1945 também não era. E esse é o ponto central que, por mais óbvio que por vezes possa parecer, é no mais das vezes negligenciado pela literatura.

Reitero a idéia com a qual iniciei este capítulo: a capacidade dos políticos de se adaptar aos resultados não é novidade, não é sequer uma anomalia, mas não significa em nenhum sistema político - nem no Brasil, pasme-se - mudar com o vento das circunstâncias apagando por completo, sempre e em todos os casos, a história, as clivagens. É importante reafirmar: o trabalho de Codato, nesse ponto, é apenas ilustrativo de um modo bastante mais difundido de sobreestimar o significado da participação nos cargos do período. Minha crítica estende-se no geral ao expediente de reduzir a relação entre políticos de São Paulo e Vargas à participação ou não participação em cargos do governo. Não quero com isso provar que a elite política paulista - que aliás não era monolítica, é bom lembrar - tenha sido em geral ferrenhamente anti-vargusita, mas apenas lembrar que ter ocupado cargos ou se filiado ao PSD ou PTB não são indícios relevantes para julgar que tenha se convertido ao varguismo.

Nesse sentido, não vejo porque não seria igualmente legítimo reivindicar a possibilidade de que esses políticos tenham sido por exemplo não-varguistas, a despeito de parte deles aceitarem cargos na máquina de governo estadual. De fato, não parece digno de surpresa que essas ditas elites paulistas participassem de um governo que não lhes dava outra opção. Pelo contrário, difícil de imaginar é que por essa falta de escolha a simples ocupação de cargos acabasse sempre e invariavelmente com as clivagens que, 
sabemos, foram duradouras em todo o país. Duradouras, portanto, até mesmo em estados que não haviam declarado uma guerra à ditadura de Getúlio. O estranhamento de Codato para com o suposto transformismo das elites paulistas já que "afinal foi em São Paulo que o 'getulismo' encontrou maior resistência política e ideológica antes de 1937 e depois de 1945" (CODATO, 2008:2) é correto. É de fato muito estranho. E talvez seja estranho porque esse transformismo simplesmente não existiu. Afinal, esse é um exemplar raro de argumento em que se é difícil provar que não houve, é mais difícil ainda provar que houve: a prova de Codato, e que está frequentemente presumida nas análises em geral sobre o período, é tautológica - receber cargos causava transformismo nas elites paulistas, e a prova disso é que receberam cargos. Ora, suposto por suposto, é muito mais razoável imaginar que políticos paulistas em geral tivessem naquele momento mais motivos para desconfiar de Vargas do que para aderir a ele por opção. A não ser que, como foi o caso, aderissem por ausência de opção melhor.

Quer dizer, defendo que isso é mais razoável porque parto daquele princípio já discutido de que elites políticas não são derivações das elites econômicas. De que “empresários lucrando" não leva diretamente a "políticos apoiando". Essa leitura usual de que paulistas teriam sido cooptados pelas nomeações de Vargas é em geral apenas a ponta da interpretação segundo a qual o ditador havia beneficiado as eleites econômicas de São Paulo. Essa á motivação pouco clara por trás da idéia simplificadora de que cargos eram indício de transformismo: já que as elites econômicas foram beneficiadas pelo varguismo, então assumir cargos nas mãos de Vargas seria apenas a captulação final. O valor de face dos ganhos econômicos. Contudo, mesmo que elites políticas fossem correias de transmissão de elites econômicas, como muitas vezes se quer, creio que esse raciocínio ainda assim mereceria advertências. Afinal mesmo no que tange às 
elites econômicas ou sociais de São Paulo, o transformismo ou cooptação são discutíveis.

Fundamentalmente, avalio esse tipo de conclusão sobre as posições da genérica elite econômica paulista como constituindo uma análise perigosamente ex post facto. É fácil olhar para o passado e vaticinar que os empresários paulistas lucraram com o Estado Novo. Até mesmo, dizer que apoiavam o governo porque dialogavam com ele e participavam de conselhos técnicos e burocracias. Mais difícil deveria ser, para esses atores sociais e econômicos preverem o futuro, ou seja, preverem que lucrariam economicamente a tal ponto com um governo hostil para com o estado de São Paulo do ponto de vista político. Fora que, mesmo prevendo seus ganhos, os industriais paulistas não conseguiriam apenas por isso convencer os políticos paulistas de que não importaria governarem o estado com mais liberdade. Ou que fosse um interesse descartável o de influenciarem mais diretamente os rumos da nação. Digo "mesmo prevendo" porque reitero: conceber tamanha clareza para com o os benefícios econômicos do projeto varguista é algo temerário. Parece-me, pelo contrário, que os paulistas - de quaisquer elites - tiveram de lidar com um típico cenário de benefícios incertos e dispersos no tempo, mas custos garantidos, claros e concentrados no presente.

No que se refere aos industriais paulistas e a sua pressuposta vinculação com a política, uma outra idéia costuma surgir a partir do clássico artigo de Bresser-Pereira (1964) sobre as origens do empresariado paulista. Bresser aponta que, em sua amostra de 204 empresários da capital e do ABC paulista entrevistados em 1962, 49\% eram imigrantes; $23,5 \%$ eram brasileiros mas filhos de imigrantes; $11,3 \%$ eram netos de imigrantes e apenas $15,7 \%$ eram de naturalidade brasileira e descendência brasileira até a segunda geração. Esses números impressionantes podem sugerir que a entrada dos industriais paulistas na política direta, política formal, fosse impossível até o fim da 
democracia de 1945. No entanto, é preciso fazer algumas ressalvas quanto a essa linha de raciocínio. Primeiro, resulta inconcebível que, porque muitos industriais não podiam entrar diretamente na vida pública dado que eram estrangeiros, não poderiam e mesmo não iriam influenciar outras candidaturas e mesmo chegar a ter representantes de seus interesses na política formal - e também eleitoral. Segundo, é necessário ressalvar que, mesmo que passassem a participar diretamente na política partidária nacional, não se deriva daí que fossem ter sucesso quer seja intrapartidário (vide Hugo Borghi, defenestrado por ser, nas palavras de Ivete Vargas, "rico demais"), quer seja ter sucesso eleitoral. Em terceiro lugar e talvez mais importante aqui, mesmo que se julgasse como resolvidos esses dois pontos anteriores, isso apenas corroboraria o argumento que proponho neste trabalho. Afinal, se o industriário não podia participar da política formal e não dava um jeito de fazê-lo indiretamente; se derivamos que isso mina uma possível fonte de poder político em São Paulo e em se aceitando a discutível tese de que os industriais tivessem consciência de seus ganhos com o modelo industrialista em todos os momentos, esse conjunto de pressupostos indigestos apenas serviria para referendar a idéia de que, em São Paulo, só restaram no fazer político aqueles grupos de elite claramente insatisfeitos com o modelo varguista. A situação de sindicatos e trabalhadores tratarei separadamente depois.

De todo modo, o debate sobre a intencionalidade da política industrial de Vargas, por exemplo, é bastante conhecido. A interpretação pioneira nesse tema coube a Celso Furtado (2007), para quem a política anti-ortodoxa de defesa do café, promovida pelo governo de Getúlio, teria levado incidentalmente ao incentivo da industrialização. É fato sabido que o governo de Getúlio começa voltado ao controle da situação agroexportadora. Sua plataforma do movimento de 1930 nada tinha de industrializante e, em verdade, o histórico de Vargas à frente do Ministério da Fazenda durante o governo 
Washington Luís desaconselharia supor qualquer afeição industrialista recôndita do ditador do Estado Novo. Mas a atuação decididamente intervencionista de Getúlio no controle da situação dos cafeicultores teria desembocado em um efeito protecionista favorável à indústria, especialmente através do controle do câmbio: "no Brasil, inconscientemente, [fez-se] uma política anticíclica de maior amplitude que a que se tenha sequer preconizado em qualquer dos países industrializados" (FURTADO, 2007:192). Nos termos de Maria da Conceição Tavares (1966), a política econômica teria visado primordialmente a defesa da economia interna contra o desequilíbrio externo - através do controle de importações, elevação de taxa de câmbio, além da compra de excedente produtivo. Para Antônio Barros de Castro (1971:92), "uma ação corretora e compensadora por parte do Estado" aos efeitos da crise de 1929. Vargas mirou na economia do café e acertou nela $e$ na industrialização do país. Para essa linha "furtadiana" de interpretação, as bases da industrialização brasileira assentaram-se antes na regulação macroeconômica que visava proteger os produtos de exportação tradicionais e afetava, por diversos mecanismos, as importações. E a substituição de importados - escassos por causa das guerras, mas também dificultados pela macroeconomia - teria sido a alavanca do desenvolvimento industrial brasileiro. Aceitos esses argumentos, dificilmente se poderia dizer estar clara, para os paulistas, uma disposição de Getúlio em projetar a indústria nacional. Disposição inicial ou mesmo posterior.

Mas essa argumentação de Furtado sofreu, de uma perspectiva liberal, a já clássica contestação de Pelaez (1972) e de Villela e Suzigan (1973). Para eles, a política econômica de Vargas na defesa do café fora, pelo contrário, desindustrializante. Se o processo de aceleração industrial do país acelerou-se, isso seria muito mais apesar da regulação macroeconômica varguista do que por causa dela. Na linha desses autores, 
seria ainda menos possível falar em projeto de desenvolvimento orquestrado por Vargas. Ao negar a eficácia da gestão não ortodoxa da macroeconomia, os autores acabaram indo além e negando papel ativo que o Estado Novo poderia ter tido no desenvolvimento industrial brasileiro. Sobre esses autores, Fonseca (2003) aponta corretamente que "voltados a refutar a importância da política 'keynesiana' de defesa do café para a indústria e em relativizar as transformações econômicas da década de 1930, pouco abordaram a questão da intencionalidade, até porque esta não era uma questão posta por suas abordagens". Isso significa que também a perspectiva crítica de Pelaez e Suzigan não permite inferir que o Estado Novo tenha desempenhado um papel na industrialização que poderia ter sido antecipado pelos paulistas - tanto faz se empresários, oligarcas ou políticos profissionais.

Por outro lado, autores como Eli Diniz (1978, 1989), Boschi e Diniz (1978) e mais recentemente Fonseca (2003) vêm apontando indícios de envolvimento direto e consciente de Getúlio na efetivação do processo industrial brasileiro. Por exemplo, as diversas instituições governamentais, conselhos, autarquias, programas de investimento e legislação pró-indústria feitos depois de 1937 e, especialmente, mais no fim do Estado Novo. Ou seja, creio que se pode interpretar essa idéia como sendo a explicação para o desenvolvimento industrial como constructo da era Vargas através não da macroeconomia, mas através da microeconomia e das mudanças institucionais.

A tese de Fonseca é a mais radical: provavelmente coloca-se como o único autor defendendo explicita e duramente que Vargas arquitetou a industrialização dos anos 30 e 40. Diz o autor:

Em contraste com a posição de Furtado, podem-se encontrar vários indícios e fatos que ajudam a evidenciar que o governo brasileiro, na década de 1930, conscientemente buscava a industrialização e a considerava uma alternativa a ser construída para a economia brasileira. Isto não significa dizer que esta consciência já estivesse plenamente configurada logo após a "Revolução de 
30”. Evidentemente ela não nasceu acabada, mas foi se fortalecendo ao longo da década (2003:10-1)

Seu texto cita indícios importantes. Desde mudanças legais até a criação da Companhia Siderúrgica Nacional, da Usina de Volta Redonda e da Companhia Vale do Rio Doce. Política creditícia, reformas nos tributos, instâncias burocráticas. E cita Getúlio: “já em 1931, Vargas afirmava a necessidade de protecionismo deliberadamente para proteger a indústria nascente: 'O protecionismo industrial das matérias-primas do país é fator decisivo, sem dúvida, ao nosso progresso econômico. É justo, por isso, que se estimule, mediante política tarifária, conduzida sem excessos"” (apud FONSECA, 2003:13).

Essa terceira vertente da literatura tem razão ao chamar a atenção para o fato de que inúmeras medidas que beneficiavam os industriais não foram feitas para a defesa dos interesses agro-exportadores. Mesmo assim, creio que a interpretação mais adequada está na linha de Eli Diniz (1978:73): se as alterações estruturais na economia brasileira fossem mera conseqüência incidental da reação ao cenário externo, "a continuidade do processo de substituição de importações ficaria comprometida pela melhoria das condições do setor externo, que marcaria o período pós-guerra". Comprometimento da substituição de importações que, segundo Maria da Conceição Tavares (1966), realmente ocorreu no restante da América Latina, mas não no Brasil.

Diniz defende que os industriais possuíram crescente peso político no Estado Novo varguista: a atuação da "burguesia industrial [...] ao longo dos anos trinta, ganharia amplitude e profundidade" (1978:70). E que, principalmente, o governo de Vargas passou a adotar medidas deliberadas pensando na industrialização: "se é verdade que, no período pós-30, o governo não possuía uma política para a área industrial, é também verdade que o anti-industrialismo não pôde manter-se como orientação 
preponderante" (ibidem). E por fim, afirma que havia "pontos de convergência entre certas concepções modernizantes defendidas pelos ideólogos do autoritarismo e certos aspectos do industrialismo explicitados pela liderança empresarial” (1978:98).

Tenho a interpretação dessa autora como sendo mais precisa do que aquela de Fonseca porque não extrapola a intencionalidade de alguns projetos do Estado Novo para um amplo projeto industrializante vindo de Vargas. É Diniz quem comenta que "ao contrário de uma política econômica rígida, marcada por um alto grau de coerência entre as várias medidas adotadas, o governo poria em prática uma política flexível e até mesmo oscilante" (p.63). E nisso está de acordo, por exemplo, com Boris Fausto, para quem "não só esse projeto não estava presente no ideário político da Revolução de 30, como também, no decorrer da chamada era de Vargas, não se teria uma política econômica coerente" e, ainda, essa política se confundiria com "medidas ditadas pelo propósito de amparar os interesses dos grupos econômicos tradicionais" (p.69).

Esse ponto pode até fazer recordar a lógica de Furtado (2007), mas independentemente de medidas objetivarem ou não interesses econômicos “tradicionais", importa reparar que boa parte dos indícios citados por Fonseca (2003) não se trataram de medidas propostas para os industriais, mas medidas gerais da economia que favoreciam a indústria. Ora, por óbvio, muitas medidas de Vargas favoreceram economicamente os industriais a despeito de terem sido projetos feitos com essa finalidade (caso de alguns) ou sem esse propósito (caso de muitos) ${ }^{28}$.

Assim como outras medidas os prejudicavam. Vanda Ribeiro Costa (1992) demonstra que a CIESP e a FIESP organizaram-se resistindo a direitos sociais que

\footnotetext{
${ }^{28}$ Provocativamente, eu perguntaria aos que julgam isso o suficiente para caracterizar os industriais como alinhados a Vargas, se estão completamente seguros de que, por exemplo, a "elite econômica" brasileira hoje se alinhe, em geral, mais à Lula do que a seus adversários, ou mesmo mais ao PT do que ao PSDB, apenas por terem atingido lucros históricos durante o governo do petista. Tenho impressão de que muitos dos que defendem a idéia do lucro econômico como o bastante para identificar vinculação das elites econômicas a Vargas, hoje não julgariam que Lula seja exatamente o dileto nome das elites atuais.
} 
surgiam de 1930 a 1945 e, também, à regulamentação dos direitos políticos de organização sindical. E insatisfeitas com o modelo corporativista da Constituição de 1934, tentavam reequilibrar forças patronais e trabalhistas propalando um modelo próprio de sindicalização: "desde então, os paulistas empenham-se em uma exegese da Constituição de forma a definir seu próprio modelo de corporativismo" (p.67). Daí que Oliveira Vianna tenha dito que a elite paulista estaria tentando ajustar a legislação sindical federal "à sua concepção de organização sindical e corporativa” (1987:253).

Os industriais de São Paulo temeram as leis de férias, os direitos trabalhistas em geral, a sindicalização, uma série de outras medidas econômicas que eram estabelecidas no mesmo momento daquelas outras incentivadoras da indústria. Eram refratários à taxação das exportações nos portos (BORGES, 1979). E mesmo no fim do período e já na democracia de 1945, quando os ganhos econômicos poderiam estar mais evidentes, os empresários paulistas reprovavam os reajustes de salário da década de 1950 (DULCI, 1986) e as greves identificadas com a esquerda varguista em 1957 e 1959. Conspiraram - sobretudo em São Paulo - com políticos e militares na década de 1960 (ação do IPES e do IBAD). Segundo Marisa Saenz Leme (1978), os industriais de todo o país se opunham à intervenção do governo na economia a não ser quando interessasse diretamente a indústria. Mais ainda, opunham-se à intervenção estatal na organização social a despeito de que futuramente ela se revelasse muito eficaz no controle dos movimentos sociais e na contenção dos levantes urbanos. Isso sem falar nas medidas que prejudicavam os oligarcas do café - justo aqueles que, se diz normalmente, estavam ainda na base da política paulista: taxação do lucro do café, nacionalização da política para o produto através do Departamento Nacional do Café, a taxação de exportações, entre outras. 
Uma última ressalva é importante. Intencional ou incidentalmente, de todo modo não é que se possa dizer que o desenvolvimento da economia paulista tenha sido uma obra de Vargas, de 1930 a 1945, ou do modelo de inspiração varguista, nos vinte anos seguintes. Para Dean (1971:91), por exemplo, “o parque industrial de São Paulo cresceu rapidamente durante os primeiros trinta anos da República”, portanto já antes da ascensão de Vargas ao comando da nação. "O valor da produção industrial paulista foi calculado em 110.000 contos em 1905, em 189.000 em 1910 e em 274.000 em 1915" (ibidem), ou seja, uma média de crescimento composto de 9,6\% ao ano nesse período. José de Souza Martins (2004) vai além e afirma que vincular duramente o processo de industrialização inicial à substituição de importações é um erro que desconsidera o papel importante e crescente das indústrias espontaneamente geradas ${ }^{29}$ nas primeiras décadas dó século XX, especialmente em São Paulo. E efetivamente, seguindo os dados de Cano (1998) e dados dos Censos Industriais do IBGE, é possível descobrir que de 1919 até 1930, a taxa média anual do crescimento da indústria de transformação paulista já era cerca de $40 \%$ maior que a taxa nacional, tendo se mantido em patamares pouco superiores ou pouco inferiores nas décadas seguintes. Além do que, "antes da 'crise de 1929’ São Paulo já concentrava grande parte $(37,5 \%)$ da indústria brasileira, com estrutura diversificada e, além disso, também aí se encontrava a mais expressiva e adiantada agricultura da nação" (CANO, 1998:47).

Quero, com isso, recuperar uma linha de raciocínio poucas vezes salientada na literatura e que nos permite perceber que, tendo sido beneficiadas as forças econômicas paulistas pelo ulterior desenvolvimento da economia nacional, isso também tinha a ver com dinâmicas econômicas anteriores à passagem de Vargas pelo poder e anteriores aos primeiros passos do modelo industrializante. Para Cano (1998:287),

\footnotetext{
29 "Espontaneamente geradas" leia-se geradas do modo tido como normal no paradigma anglo-saxão de Revolução Industrial, não pelo processo de substituição de importações - frequentemente tido, no fundo, como desviante por ser estabelecido via indução.
} 
Em síntese, a liderança do desenvolvimento capitalista em São Paulo, uma vez obtida (pré-1930), tendeu a acentuar-se por razões que dizem respeito, antes de mais nada, à dinâmica do próprio pólo. Quer dizer: essa liderança pode ser entendida pela crescente capacidade de acumulação de capital em São Paulo, com marcante introdução de progresso técnico e diversificação de sua estrutura produtiva. Mais ainda: esse processo de concentração industrial obedeceu - conforme diz a boa doutrina - à fria lógica capitalista de localização industrial.

Ou seja, afirmar que a economia paulista ganhou com o modelo varguistadesenvolvimentista é diferente de dizer que fazê-la ganhar fosse um objetivo. É claro que em alguns casos sim, como na queima de café para valorização do produto, política que se enquadra no seguinte comentário de Maria do Carmo Campello de Souza: "quer gostassem ou não, governo e empresários paulistas tinham de concordar num ponto: a ‘salvação' de São Paulo, boa para os empresários, era ótima para o país, pois salvava a economia como um todo" (1977:79). Mas em muitas outras situações, o prejuízo ou o lucro econômico dos paulistas pode ter sido meramente incidental. A política econômica mais ampla não era pensada em termos de prejudicar ou não as elites econômicas de São Paulo e, como observa Wilson Cano no trecho citado, uma vez que apontasse para a modernização da economia nacional, tenderia a privilegiar regiões cujo bakcground econômico fosse, já anteriormente, mais propício ao acúmulo de capital e à atração de novas atividades modernas. Howard Gauthier e Robert Sample, em artigo de 1977, colocam a questão de maneira clara:

Apesar do governo ter seguido uma estratégia de desenvolvimento setorial seletivo, pouca atenção foi dada à locação espacial do crescimento. O padrão regional do crescimento durante a década de 40 e o início da década de 50 foi, sem dúvida alguma, um resultado da seleção de setores industriais para desenvolvimento, muito mais do que qualquer estratégia consciente de considerar ou tratar desigualdades no crescimento regional (1972:10) 
Penso serem essas as chaves pelas quais devemos abordar a relação da economia paulista com os desdobramentos da política e da política econômica nacional. Os projetos, modelos e políticas econômicos adotados em escala nacional desde a Revolução de 1930 não necessariamente visavam beneficiar a elite econômica paulista, mas certamente - e isso é central - não se opunham a esse resultado. E tampouco zelavam pela correção de desequilíbrios regionais. Esse tipo de preocupação regional, como bem identifica Amélia Cohn (1978), só iria passar ao cerne das atenções políticas no final de década de 1950, com a grande seca de 1958, com o fortalecimento de movimentos campesinos e, como lembra Cano (1977, 1998), com a acentuação das disparidades regionais derivada dos novos processos de industrialização pesada do desenvolvimentismo pós-Vargas. Como lembra Marlene Cohen (2006:92), apenas em 1958, em uma reunião para discutir a situação nordestina alarmante, Juscelino Kubitschek tardiamente diria a Celso Furtado: "lamento que esta reunião não se tenha realizado no começo do meu governo. Doravante, o Nordeste terá a mesma prioridade de Brasília”.

Em primeiro lugar, portanto, seria muito duvidoso afirmar que, do ponto de vista econômico, o governo de Vargas ajudou intencionalmente ao estado de São Paulo quanto entidade federativa. Ou mesmo às suas "elites econômicas" de forma especial. Ajudou-as, mas de roldão no processo industrial mais geral do país. E em segundo lugar, mesmo no que se refere a esse processo, há dúvidas quanto ao grau e ao timing da consciência dos atores em relação aos resultados finais positivos que acabaram por auferir. Julgar que elites econômicas tinham plena clareza antecipada dos resultados futuros não procede. Se grupos empresariais se aproximaram do governo Vargas, creio um exagero chegar a dizer, como faz Leme (1978:30), que “com a implantação do Estado Novo, entretanto, já se acha consolidada uma situação em que a defesa dos 
interesses regionais perde sentido. Os industriais paulistas não hesitam, em união com os colegas do restante do país, em hipotecar solidariedade ao novo regime”. Realmente, legitimaram o Estado Novo, especialmente no sentido de louvar a proteção que o regime passou a garantir contra a agitação popular. Mas dizer que não hesitaram é exagero. A forma apropriada de colocar a questão, creio, está no seguinte trecho de Diniz (1978:73): “a aludida indefinição do governo no que se refere à elaboração de um projeto global de desenvolvimento econômico não impediu que, do confronto entre as diversas tendências, resultasse o predomínio de uma linha identificada com a necessidade de mudança da estrutura produtiva do país". O grifo é meu: do confronto de diversas tendências. Foi preciso conflito, não se tratou de um processo automático. E confronto implica, necessariamente, no desconhecimento dos resultados do embate. Tratou-se de uma construção cuja conclusão nós conhecemos, mas que não se conhecia à época.

Por fim, chego a essas conclusões no que se refere à situação das elites econômicas paulistas no período 1930-45 por ter consciência da importância do debate e para mostrar que mesmo nesse âmbito os ganhos paulistas não eram tão óbvios. Mas, de minha parte, além de discordar que seja possível pensar em "elites econômicas" ou mesmo "industriais" de São Paulo como sendo grupos uniformes, de interesses sempre convergentes ou mesmo de interesses universalmente atendidos, tampouco acho provável que um suposto lucro comum dessas elites genéricas tenha desempenhado influência direta, automática e não mediada no posicionamento dos políticos do estado em relação a Vargas.

Nesse sentido, Lamounier (1994:27) assinala sobre as relações políticas do período Vargas que:

O processo de state-building empreendido pela Revolução de 1930 com o objetivo de romper o condomínio oligárquico da República Velha foi 
um percurso tortuoso, que acabaria criando condições favoráveis ao amortecimento dos antagonismos no longo prazo, mas que os tornou de certa forma até mais graves no curto prazo.

Afinal, os paulistas não apenas reagiram ao novo regime com uma guerra civil ao governo central e com a criação da mais importante universidade do país buscando uma nova "formação das classes dirigentes" (decreto estadual 6283/34). Apesar de ser verdade que os dois principais pólos da política paulista participaram do governo Vargas em momentos diferentes - primeiro o Partido Democrático, logo em seguida à revolução de 1930, depois o Partido Republicano Paulista, após o golpe de 1937 - o período passaria até mesmo pela união das historicamente opostas elites do estado sob a Frente Única Paulista de oposição à Vargas, durante breve tentativa democráticolegalista de 1934-37. Na oportunidade que julgavam ter de derrotar o ditador no caso das eleições que estavam previstas, os principais grupos políticos paulistas não hesitaram em se unir contra Vargas a despeito da rivalidade local que sempre nutriram.

Tampouco se pode irrelevar que, de 1930 a 1945, São Paulo tenha possuído 10 diferentes governantes, entre interventores e o governador eleito sob a Constituição de 1934, contra uma média de 4,3 e mediana de 4 para o resto do país ${ }^{30}$. Ou seja, o ajuste da política paulista com a política varguista era instável, delicado e problemático. A partir do novo golpe de 1937, Vargas passa a procurar lideranças das próprias oligarquias de São Paulo para formar as interventorias do estado. No entanto, é evidente que o tipo de acordo possível naquela altura é uma trégua, não uma troca de cargos por apoio. O principal interventor paulista entre 1937 e 1945, Adhemar de Barros, até ser nomeado fazia sua carreira precisamente inflamando discursos virulentos contra Getúlio Vargas (SAMPAIO, 1982). E é sintomático que, na democratização, Adhemar tenha começado sua inserção no quadro eleitoral filiando-se exatamente à UDN anti-varguista

\footnotetext{
${ }^{30}$ Excluindo-se interventores ou governadores interinos.
} 
(caminho seguido por apenas $8 \%$ dos interventores que passaram pelos diversos estados do país ao longo do período ${ }^{31}$ ). E exatamente numa das seções estaduais da UDN que era mais claramente radical ao varguismo (BENEVIDES, 1981). Pouco importa que Adhemar tenha sido mal quisto pelos udenistas de São Paulo, a ponto de logo em seguida largar a legenda para formar seu próprio partido político.

Mesmo os intelectuais paulistas, há poucas dúvidas, tiveram dificuldades para abandonar completamente os alinhamentos políticos pregressos. Sobre eles, vale a pena citar o que Daniel Pécaut (1990:173) assinala sobre as diferenças dos paulistas em relação aos intelectuais cariocas ao longo da democracia de 1945. Elas estariam ligadas, também, "às experiências políticas anteriores e ao ambiente político: no Rio, a recuperação do getulismo como matriz do nacionalismo e a multiplicação das greves políticas; em São Paulo, a desconfiança em relação ao legado do Estado Novo e a confusão diante das 'massas' que servem de suporte a sucessivas vogas populistas”. E em seguida, comentando sobre as elites e sobre os intelectuais do estado de São Paulo, completa: "as humilhações de 1932 e 1937 ainda permanecem muito vivas para que não percebam no Getúlio Vargas de 1950 a continuação do Getúlio Vargas de 1930 [e] no nacionalismo que se apossa do Brasil a partir de 1955, uma maneira de preservar o domínio autoritário do Estado sobre a sociedade [...]” (p.174).

Afinal, se politicamente, como diz Woodard (2006:84), "São Paulo was Vargas's greatest political concern", ouso dizer que, no campo da política, também Vargas era a principal preocupação dos paulistas. A despeito do lucro econômico que viriam a ter. Declaradamente utilizando-se do termo "classes cultas" no sentido de "better class paulistas" ou "upper classes", o autor afirma com perspicácia: "put more succinctly, Vargas was not hated by the classes cultas because he was a populist; he

\footnotetext{
${ }^{31}$ Excluindo-se as Juntas Governativas, interventores interinos e aqueles interventores que morreram antes da democratização.
} 
was a populist because he was hated by the classes cultas" (p.93). De todo modo, deixa clara a relação difícil entre esses grupos e o varguismo e explica a idéia: "regionalism, snobbery, and anti-varguismo among upper-class paulistas contributed do Vargas's ability to reinvent himself as a "populist"' (p.98). Mais importante ainda, Woodard assume a vinculação entre o alinhamento anti-varguista de São Paulo e o regionalismo que caracterizou as relações conturbadas entre esse estado e a nação conduzida por Getúlio. Sua formulação não poderia ser mais clara: "as many of these examples make clear, anti-varguismo, regionalist identity [...] became entangled in the thinking of São Paulo's classes cultas".

Depondo sobre a criação da UDN em São Paulo, Carlos Lacerda deixa clara essa influência do passado político em parte dos políticos paulistas: "começou a ser articulado [o partido] em São Paulo, através das ligações com o Julinho [de Mesquita Filho] e com o pessoal de lá. Mas o grupo de São Paulo, do Partido Democrático, tinha aos nossos olhos um matiz muito reacionário [...]" cuja posição era "muito conservadora, muito regional. Combatiam o Getúlio menos pelos efeitos maléficos que ele pudesse ter nacionalmente, do que pelo fato de que aos paulistas a Revolução de 30 soou como uma tentativa de destruir a influência de São Paulo na federação, o que realmente aconteceu" (1978:31). Não creio que haja motivos concretos para imaginar que a percepçãoe a desconfiança tenham sido diferentes para a parcela de paulistas que tomou parte nos cargos do Estado Novo. Salvo assumir de antemão que esses formadores da UDN eram menos suscetíveis ao pragmatismo e ao canto de sereia da máquina pública varguista, como se fossem paulistas de maior brio e mais resiliência. Como se sabe, aliás, esse mesmo grupo de que Lacerda fala foi exatamente aquele que fez parte, em primeiro lugar, do governo pós-revolucionário de Vargas na década de 30. 
Mas de todo modo, meu objetivo até esse ponto foi, tão somente, levantar a idéia de que os atores políticos de São Paulo talvez não tenham estabelecido uma relação de alinhamento ao varguismo, mesmo aqueles que participaram da máquina de governo do Estado Novo. Relativizei a idéia de que participação de um governo ao qual não existem alternativas não significa, de modo algum, anuência a um projeto ou ao grupo de forças que representa esse governo ditatorial. Assumo que nem mesmo os ganhos das elites paulistas seriam garantia de fazer os políticos profissionais paulistas alinharem-se ao varguismo. E mesmo assim, há sérias razões para se desconfiar de que nem mesmo esses ganhos econômicos tenham sido claros ou antecipados pelas partes envolvidas.

Em suma, se é difícil levantar provas irrefutáveis de que os políticos paulistas em geral mantiveram-se distantes de Vargas, isso é apenas tão difícil quanto provar o sempre suposto de que apenas participar do governo estadual garantisse o alinhamento de médio e longo prazo dos grupos envolvidos. Leia-se: alinhamento para o pósditadura, quando passaria a haver a alternativa da alternância de poder. Ora, desconstruída a idéia de que a mera ocupação desses cargos seja prova de "transformismo" dos políticos de São Paulo - processo que se teria originado quer pela sanha por cargos, quer pelos ganhos econômicos da indefinida elite econômica sobram muito mais motivos para se imaginar o contrário: que posicionamentos influem ao longo do tempo. Nesse caso não seria, então, assim tão fácil para um político profissional das "elites" paulistas justificar sua adequação ao varguismo perante seus pares, seus próximos, seus círculos, perante os futuros eleitores, ou mesmo confiar ao varguismo seu futuro, sua carreira, seus interesses - pessoais ou de "elite".

Os alinhamentos pregressos e a relação política anterior dos políticos paulistas importam. Mesmo quando eles aceitam participação no governo como um mal menor, como o bem maior possível no momento. Nesse ponto, julgo necessário esmiuçar o 
aparato teórico no qual filio essa afirmação anterior. Trata-se do conceito de path dependency em sua versão mais recortada tal como sugere Pierson (2000, 20004), ou seja, uma particularização da idéia geral de que a história importa. Como havia dito ao iniciar este capítulo, Pierson indica que essa concepção genérica de que o passado define as possibilidades de futuro é apenas um começo: "this usage may entail only the loose and not very helpful assertion that 'history matters"” (2000:252).

A definição mais delimitada proposta para o conceito de dependência da trajetória seriam os processos de increasing returns, em que "the probability of further steps along the same path increases with each move" (ibidem). Essa classe de fenômenos apresentaria, em geral, três grandes características: (1) imprevisibilidade, (2) inflexibilidade e (3) grande papel desempenhado pelo timing e pela seqüência dos acontecimentos $^{32}$. Classificar uma realidade política dentro desses termos mais restritos poderia indicar efetivamente a existência de realidades políticas desenrolando-se sob a forma de dependência presente do caminho trilhado no passado.

Julgo que a relação desenvolvida entre os políticos paulistas e o varguismo aproximou-se muito mais da caracterização de um processo dessa natureza. Classifico a situação como configurando um cenário de retro-alimentação que atende aos parâmetros do conceito. Em primeiro lugar, o momento inicial da relação entre Vargas e os paulistas configurou um cenário de imprevisibilidade, verdadeiro equilíbrio de possibilidades, como quer Pierson. Não seria possível antecipar a evolução dos acontecimentos imediatamente posteriores à Revolução de 1930: ela era vista como um golpe claro contra o domínio político de São Paulo, mas certamente não havia clareza da dimensão que isso poderia ou deveria tomar. O próprio Vargas, questiona-se,

\footnotetext{
${ }^{32}$ Em verdade, o autor desdobra esse último ponto e chega a uma quarta característica: a possibilidade de que, no tempo e na seqüência corretos, eventos pequenos possam ainda assim ser determinantes. No entanto, para fins de simplificar o debate, conjugo essa idéia e acabo com apenas 3 grandes características.
} 
enxergava inicialmente seu movimento como muito mais tópico e conjuntural na correção do peso político paulista. A ponto de que não pretendia ensejar um novo regime e sim apenas estabilizar o ponto a que haviam chegado as querelas regionais (BORGES, 1979; FAUSTO, 1986).

Em segundo lugar, especialmente, creio que essa relação seja exemplar da inflexibilidade inerte pela qual "the farther into the process we are, the harder it becomes to shift from one path to another" (PIERSON, 2000:253). Esse é o ponto central no qual baseio a sugestão de que a elite política paulista, sendo a mais claramente anti-varguista de todo o país, desenvolveu um relacionamento com o varguismo que era marcado por esse posicionamento anterior. Não faz sentido esperar que todos os diversos grupos políticos do país tenham se ajustado com igual azeitamento à era de Vargas, malgrado o tipo de ligação refratária ou entusiasta com que se vinculassem ao ditador. Pelo contrário. É de se esperar diferentes padrões e graus de alinhamento dependendo exatamente das trajetórias políticas dos políticos de cada estado. Diga-se de passagem, aliás, a tradução do termo path dependency, tantas vezes desabonada, constitui para minha pesquisa um acerto formidável: dependência da trajetória. As trajetórias dos políticos fazem diferença. Sofrem efeito de justaposição pelos novos acontecimentos, como por exemplo participar do governo de Vargas. Mas daí a dizer que sejam apagadas por completo em tão curto espaço de tempo, significaria sobreestimar a capacidade pragmática de nossos políticos e também subestimar a história.

E por fim, em terceiro lugar, não há dúvida que essa relação entre Vargas e políticos de São Paulo tenha sofrido sobremaneira o efeito do timing e da seqüência em que ocorreu. Afinal, foram marcadas exatamente por sucederem o advento do projeto político de 1930, sabidamente anti-paulista do ponto de vista governamental. A 
descrição de Pierson sobre essa terceira característica é muito interessante até mesmo para repensar a idéia do envolvimento de políticos paulistas com a máquina estadonovista: "timing and sequence [implicam em que] because earlier parts of a sequence matter much more than later parts, an event that happens 'too late' may have no effect, although it might have been of great consequence if the timing had been different" (p.263).

Minha concepção da situação dos políticos paulistas nos aos 30 e 40 não é mera divagação. Pelo contrário, constitui o nexo mais elementar do que creio ter acontecido à política paulista no período democrático de 1945. De um modo ou de outro, sugiro que as reações despertadas por Vargas e pela relação dele com as elites do estado de São Paulo alteram profundamente a formação do sistema nacional de partidos nesse estado, de modo a prejudicar, no futuro, a inserção dos políticos paulistas na política nacional. Justamente o estado maior da nação, o mais rico, mais populoso. $\mathrm{O}$ anti-varguismo muito mais ferrenho e o não-varguismo muito mais difundido faziam, primeiro, com que as elites políticas paulistas tivessem um aproveitamento muito diverso da passagem pela máquina estadual para organizar suas forças na democratização. E segundo, faziam com que, de modo persistente no tempo, esses políticos marcassem os posicionamentos dos grupos paulistas na democracia nascente com a cunha das singulares clivagens paulistas. 


\section{Capítulo 4}

\section{Formação dos partidos em São Paulo e a democracia de 1945}

Durante a democracia de 1945, o estado de São Paulo foi a única unidade federativa em que, simultaneamente, os três grandes partidos do Brasil foram pouco significativos. No Rio de Janeiro, por exemplo, a disputa política ficava concentrada entre udenistas e petebistas, o PSD sendo um partido bastante secundário. Para Lima Jr et al. (1987), a radicalização entre varguistas e anti-varguistas representava, nesse estado, a clivagem geral do país em seu tipo mais puro: "foi daqui [Rio] que Getúlio Vargas governou por quase 20 anos. Em função disso estamos inclinados a pensar que o PTB carioca já nasceu com forte apelo popular e extremamente comprometido com a tradição trabalhista", enquanto que, "em perfeito contraponto, a UDN carioca é o partido que mais se notabiliza por seu antigetulismo. Se o Rio de Janeiro é o principal lócus de experimentação da política de Vargas, naturalmente é também o principal foco de oposição a ela" (p.176). No Rio Grande do Sul, segundo Cánepa (2005), a UDN era um partido muito diminuto, sendo complementada por outro de caráter estadual, o PL. Enquanto isso, PTB e PSD é que realmente dominavam o cenário estadual gaúcho, no que acabava moldando a política do estado em um embate dominado por políticos mais alinhados a Vargas. Já em Minas Gerais, o PTB é que era um partido de menor importância. Superava-o até mesmo o Partido Republicano (PR), legenda regional nascida com caráter sabidamente mineiro. Em geral, os petebistas não chegaram a ser de todo fracos nesse estado, mas não ameaçavam a briga entre PSD e UDN (CARVALHO, 1957) - disputa que se configurava, para as duas legendas, seguindo a fama da política mineira de ser das mais moderadas do país. 
Apenas em São Paulo esses três principais partidos nacionais eram, todos eles, forças de pouca expressão no estado. Elegiam relativamente poucos deputados estaduais, nunca elegeram governadores. E como vimos no segundo capítulo, tinham penetração dos votos para deputado federal abaixo do esperado. Ao mesmo tempo, dos partidos caracteristicamente estaduais daquela democracia, foram apenas as versões paulistas que conseguiram dominar seu estado de origem. Em São Paulo, o paulista PSP predominou, mas algumas das forças menores em disputa também eram legendas com desenvolvimento fortemente concentrado no estado, como o PDC e o Partido Trabalhista Nacional (PTN), partidos pelos quais passou Jânio Quadros.

Seguindo o argumento que venho construindo ao longo dos últimos capítulos, creio que a melhor especificação sobre a situação da política paulista em relação à política nacional entre 1945-64 é a negação do fenômeno que Lima Jr. (1983) enxerga ocorrer no quadro geral do país: nem os principais partidos nacionais penetraram em São Paulo no mesmo nível que cosneguiram no restante da nação, e nem as forças políticas surgidas ali conseguiram em geral se nacionalizar. Nesse sentido, sugiro que a formação de cada partido no estado, bem como seu desenvolvimento, sejam os objetos centais para explicar e oferecer indícios dessa situação. Aqui, meu pressuposto, por certo, é o de que seria mais difícil aos políticos paulistas conseguirem inserir-se no jogo político-democrático nacional, em comparação à inserção de representantes de outros estados, se os principais políticos de São Paulo estavam em legendas diversas daquelas que davam a tônica da democracia no país. Ora, um baixo desenvolvimento das três grandes legendas nacionais em São Paulo significava, certamente, menor número de paulistas diretamente ligados à disputa que se deva no nível federal. Afinal, a força da política paulista acabou concentrada em partidos e grupos políticos de fora do mainstream governista e também do oposicionista. Isso não significa que membros, por 
exemplo do PSP, não conseguissem penetrar ou influir na política do Brasil. Pelo contrário, conseguiram, e uma prova disso é a aliança entre Ademar de Barros de Getúlio Vargas paras as eleições de 1950. Apenas significa que a inserção de boa parte dos políticos paulistas teria de se dar desse modo: como outsiders tanto nas forças de situação quanto nas de oposição. Partidos paulistas alheios à dinâmica principal da nação e partidos nacionais fracos em São Paulo resultavam, principalmente, em dificuldade de nacionalização de lideranças paulistas. Ainda que, é bom ressalvar, dificuldade não seja o mesmo que impossibilidade.

Estou ciente do principal risco decorrente de concentrar atenção na formação de partidos políticos, que é o risco de imaginar que o status inicial se reproduz e se perpetua, de modo que os resultados finais sejam analiticamente postos como prédeterminados ou inexoráveis pela origem. De fato, a alteração do status quo ante partidário nunca é um processo simples. Certamente, esse status tende a conformar claramente um cenário institucional de tipo self reinforcement. Mesmo assim, seria plenamente possível que qualquer legenda política inicialmente fraca fosse ganhando mais substância organizacional e eleitoral ao longo do tempo a despeito de sua formação original. E em verdade, creio mesmo que a democracia de 1945, abortada precocemente pelo golpe, pudesse guardar todo tipo de surpresas à medida que as preferências e as opções políticas se consolidavam. Nesse mister, oriento-me também pela ressalva de Antônio Lavareda: “com efeito, o número reduzido de pleitos na fase inicial de qualquer sistema acaba dificultando a identificação de eventuais tendências assumidas por ele" (1991:51).

De todo modo, neste trabalho meu objetivo é demonstrar como a formação inicial dos partidos dificultou essas surpresas, moldou as linhas gerais do sistema político em São Paulo através da relação da política paulista em geral para com o 
varguismo. Os espaços políticos foram sendo preenchidos de forma singular no estado e a situação foi conformando os discursos e as perspectivas de poder por parte dos políticos paulistas, como pretendo sugerir. Não sendo teoricamente impossíveis as mudanças nas correlações de força partidária, elas acabaram por ser bastante raras. Os casos mais notórios estão na situação do PTB - cuja relevância em São Paulo decai ao longo dos anos - e na do PCB, cuja força inicial nada garante contra o evento pontual e determinante da cassação e ilegalização. As outras legendas obedeceram, em geral, o padrão de desempenho político garantido por sua formação política original. A começar pela entrecruzada relação competitiva entre PSD, PSP e UDN, central para entender boa parte dos desenvolvimentos da política do estado naquele período.

\section{O Partido Social Democrático (PSD)}

Em praticamente todas as seções estaduais ao longo do país, o Partido Social Democrático era o "partido dos interventores” (BENEVIDES, 1981). Organizou-se nos estados, segundo Lúcia Lippi Oliveira (1973:18), “sob a chefia dos interventores, ou daquelas pessoas de grande projeção política diretamente ligadas à interventoria", além de terem participado "da formação do PSD, além dos interventores, os homens que compunham o seu secretariado e auxiliares, enfim os responsáveis mais diretos pela administração do Estado Novo". O partido formou-se através dos quadros e da máquina governamentais que a ditadura varguista utilizava para governar os estados (SOUZA, 1976), incluindo também os "daspinhos" (CODATO, 2008). Mas além desses participantes diretos dos cargos de governo, também "as figuras de algum destaque no município e no estado foram chamados a compor as fileiras da organização partidária mandada fundar pelo governo federal, pelo presidente Vargas. Ficaram de fora aqueles 
que tinham se sentido prejudicados pela administração do Estado Novo" (OLIVEIRA, 1973:18).

Para se ter uma idéia do peso dessa origem, basta dizer que os interventores nomeados por Vargas para ocupar mais ou menos a função de governadores de província - não apenas administravam os estados ao lado das seções locais dos Departamentos Administrativos do Serviço Público (DASP), como eram ainda os responsáveis pela nomeação de praticamente todos os prefeitos de todas as cidades brasileiras. Evidentemente, nesse sentido, o PSD surgia como um partido mais forte, mais nacionalizado e mais organizado do que os demais já logo no início do período democrático que se iniciava em 1945. Largava na corrida democrática com uma estrutura organizacional que cobria todo o território nacional (LIMA Jr. et al., 1987; SOARES, 1981; SOUZA, 1976). E, com resultados eleitorais condizentes, iniciou a democracia como a legenda mais forte do país (HIPPOLITO, 1985; SOUZA, 1976). Diga-se de passagem, aliás, configurou no pleito de 1945 o único caso de uma legenda efetivamente majoritária na história do $\mathrm{Brasil}^{33}$.

Não à toa, o PSD conformava em geral um partido situacionista, de políticos muitas vezes oriundos das elites estaduais tradicionais, mas que sem dúvida tinham aderido em diferentes graus ao governo Vargas durantes o Estado Novo. Alguns desses políticos em alguns estados haviam apoiado aberta e até enfaticamente já a Revolução de 30 e portanto estavam realmente alinhados a Getúlio desde o início. Outros se somavam ao comboio varguista no intuito muitas vezes de rivalizar com adversários em seus próprios estados, que haviam sido derrotados pela ascensão de Vargas. De um modo ou de outro, os interventores e seus grupos oligárquicos provinciais aderiam ao governo, compunham com a ditadura e na democratização do país formaram, assim, um

\footnotetext{
${ }^{33}$ O PSD atingiu, em 1945, 53\% das cadeiras na Câmara Federal e 59\% das cadeiras no Senado. Nunca, em uma eleição democrática, algum partido conseguiu ser majoritário no Brasil em qualquer das duas casas do Congresso, dado o multipartidarismo de fragmentação moderada.
} 
partido relativamente varguista de matiz centrista e moderada, ligado a oligarcas do passado. E, segundo Hippólito (1985) e Oliveira (1973), com base eleitoral marcadamente interiorana. Esquematicamente falando, o PSD tinha algo de varguismo do mundo rural, deixando ao PTB o espaço de varguismo do mundo urbano.

Além disso, restam poucas dúvidas, o PSD desempenhava o papel de moderador do regime. Para Campello de Souza (1976), era o partido de esteio que mantinha a aliança entre conservadores e progressistas em eficaz funcionamento. Para Hippólito (1985), era mais exatamente o moderador do regime democrático: o PSD desempenharia, ele mesmo, o papel de grande "centro político" do sistema partidário, na intermediação entre a crescente radicalização nacional de PTB e UDN. As palavras de Barboza Filho resumem bem a idéia ao dizer que aquele sistema partidário, no que se refere às clivagens do varguismo, teria se desenvolvido com "o PSD representando o ‘equilíbrio' necessário ao pacto modernizador-conservador e a UDN a histeria antivarguista legitimadora da fundação do pessedismo" (1995:107).

O cenário era, contudo, bastante diverso no estado de São Paulo. A famosa frase que o pessedista Pacheco Neves atribui a seu correligionário Tancredo Neves não deixa dúvidas sobre a debilidade eleitoral do partido nesse estado: “o PSD de São Paulo era tão importante que cabia todo na sala de visitas do Cirilo Júnior”. Com efeito, a atuação do PSD em São Paulo era uma mera sombra do vigor político da legenda em nível nacional e na maioria dos outros estados brasileiros. O PSD jamais alcançou o governo do estado e na Câmara dos Deputados, salvo a eleição de 1945 em que os outros partidos ainda não lhe faziam frente até por não terem o mesmo background organizacional, teve em média apenas 19\% da bancada paulista. Para Hippólito (1985), ainda, o partido não conseguira escapar de estar espremido em São Paulo entre as lideranças de Adhemar de Barros (do PSP) e de Jânio Quadros (do PDC e depois do 
PTN). E seguramente não desempenhou no estado, nem de longe, o papel estabilizador e moderador entre varguistas e não-varguitas.

Acontece que o PSD paulista teve em sua formação uma singularidade que vem passando despercebida à literatura política sobre o Brasil da época. Enquanto a formação das interventorias estaduais durante o Estado Novo deu-se através da cooptação de oligarcas dispostos a apoiar e a cerrar fileiras com o varguismo, no estado de São Paulo, pelo contrário, a interventoria era cedida a oligarquias que não apenas eram sabidamente anti-varguistas ou pelo menos não-varguistas, como eram os grupos políticos que ali mesmo haviam declarado uma guerra contra-revolucionária à nação de Vargas em 1932. E que estavam ineditamente unidos para demover os próceres de Getúlio do poder em 1937 através do apoio à candidatura de Armando Salles de Oliveira. Entre outros exemplos tratados no capítulo anterior, quando argumentei que o ajuste da política paulista com a política varguista era instável, delicado e problemático. Em outras palavras, Vargas não encontrava em São Paulo elites regionais dispostas a realmente endossarem o varguismo, mas tampouco poderia governar às expensas do total alijamento das elites do estado de São Paulo, ou à sua revelia (LOVE, 1982).

A literatura é unânime em diagnosticar, acertadamente a meu ver, que a experiência de nomear interventor um militar não paulista em 1930 ensinara a Vargas que cedo ou tarde precisaria acomodar a elite do estado dentro do arcabouço institucional de sua ditadura. E mais do que isso, ensinou a Vargas que seria muitíssimo custoso retirar por completo, das mãos das elites paulistas, a possibilidade de participar dos rumos políticos do estado. Desse modo, elas precisavam ser incluídas no sistema de interventorias tal como as elites provinciais de outras regiões - mesmo que fosse difícil imaginar que as lideranças políticas paulistas em qualquer momento tenham deixado de ser anti-varguistas ou na melhor das hipóteses não-varguistas. Mesmo que ali não 
perfizessem um rol de apoiadores à ditadura de Vargas, portanto, também em São Paulo o modelo de organização de poder adotado depois de 1937 foi o de nomear membros das elites regionais que não fossem de grande expressão dentro delas, de modo que seriam sim representantes desses grupos, mas teriam seus mandatos graças a Vargas e dependentes da vontade do ditador. A partir do novo golpe, Vargas passa a procurar lideranças das próprias oligarquias de São Paulo para formar as interventorias do estado. No entanto, é evidente que o tipo de acordo possível naquela altura é uma trégua, não uma troca de cargos por apoio.

O mais importante é notar, por um lado, que o PSD que surgiu em São Paulo em 1945 não nasceu forte, pois não se aproveitou da máquina de governo tal como em outros estados. Ao contrário: poucas lideranças políticas do estado aceitaram marchar ao lado de Vargas no período democrático que se iniciava. E mesmo esse débil PSD paulista cairia nas mãos de líderes que provavelmente não eram anti-varguistas, mas eram pelo menos não-varguistas: o PSD do estado seguiria, durante praticamente toda a democracia, ao lado da UDN. Ao lado da seção estadual udenista que, sabe-se, era a mais intransigente em relação ao varguismo (BENEVIDES, 1981). E até mesmo no início da democracia de 1945, quando o PSD nacional divide-se entre uma ala mais próxima de Vargas e outra mais alinhada ao presidente Dutra, os pessedistas de São Paulo, em geral, acabaram mais identificados com o presidente Dutra (1945-50), ou seja, com o grupo do PSD que confrontava o domínio de Vargas dentro da legenda (OLIVEIRA, 1973). Comentando sobre o posicionamento da UDN no estado de São Paulo nas eleições estaduais de 1947, Benevides refere-se da seguinte maneira ao PSD paulista: "a vitória de Ademar de Barros em São Paulo [...] já contribuira para reforçar, na UDN, a consciência de que era urgente aliar-se ao PSD não-getulista" (1981:75). O grifo é meu e tem o intuito de salientar a impressão, muitas vezes subentendida na 
literatura, de que a seção paulista do PSD definitivamente nunca foi tão próxima de Vargas ou do varguismo.

Sérgio Miceli fornece um outro indício curioso ao comentar que "São Paulo foi, praticamente, o único estado da federação onde o PSD se valeu do apoio de elementos pertencentes à mesma facção da classe dirigente que contribuiu com as figuras de maior destaque para a 'ala dos bacharéis' udenistas" (1989:572-3). Ala que, vale lembrar, era das mais ferozes no ataque ao varguismo (BENEVIDES, 1981). Nesse mesmo texto, Miceli aponta ainda que a diferenciação entre PSD e UDN, em São Paulo, não seguia o padrão nacional de apresentar políticos de origem similar, mas clivados pela proximidade ou afastamento a Vargas. Para o autor, "em São Paulo, a composição de ambas as chapas difere consideravelmente dos padrões acima referidos. As clivagens que orientam o realinhamento das forças políticas no estado remontam às dissensões internas ao situacionismo oligárquico [pré-revolução de 1930]" (1989:572). Ou seja, nesse raciocínio de Miceli, o que diferenciou a formação de PSD e UDN em São Paulo teria sido antes uma briga intra-estado anterior a Vargas. À revelia, portanto, dos alinhamentos ao varguismo. E de minha parte, acrescentaria por decorrência: à revelia exatamente porque ambos os lados eram, em geral, no mínimo não-varguistas.

O PSD paulista foi, portanto, uma das poucas (se não a única) seções do partido formada por membros cujo alinhamento a Vargas havia sido tão problemático antes e depois de 1945. Ainda que consistisse, junto do PTB, no principal destino daqueles políticos estadonovistas que fossem alinhados ao ditador. Quero dizer: não é que não houvesse varguistas no partido. Pelo contrário, parte dos mais ardorosos defensores paulistas do projeto do ex-ditador seguramente foram parar no PSD. Ao mesmo tempo, tampouco seria possível afirmar que o PSD de São Paulo não tivesse nenhuma liderança importante para a legenda, como por exemplo Ranieri Mazzili, que chegou a presidir a 
Câmara Federal por vários anos da democracia de 1945. O argumento que proponho é apenas a idéia de que, de um modo ou de outro, o PSD no estado não chegou a constituir uma seção tão próxima de Vargas e tampouco conseguiu arregimentar, em sua formação parcela significativa dos participantes da burocracia do Estado Novo. Como se não bastasse, veremos a seguir, a formação do PSP e a vitória de Adhemar de Barros para governar o estado em 1947 ensejaram forte migração de quadros pessedistas ao partido vitorioso, que tinha sido o mais importante destino dos políticos paulistas ligados ao Estado Novo (SAMPAIO, 1982).

Mas se é verdade que o caráter próximo à UDN ou ao menos mais distante de Getúlio que foi sendo assumido pelo PSD paulista causa surpresa, é motivo de ainda maior espanto perceber que boa parte da elite política do estado, que estivera no governo estadual durante a ditadura, nem mesmo assim foi parar nas fileiras desse partido. Afinal de contas, é de se pensar: se os paulistas lotados na máquina do Estado Novo eram varguistas por profissão de fé, poderiam perfeitamente ter ido para o PSD, seguindo o padrão nacional e fazendo o PSD paulista nascer como um partido pró Vargas usual. E se ao contrário, esses membros das elites apenas toleravam o projeto de Getúlio e continuavam distantes do varguismo, aí das duas uma. Ou poderiam ter ido massivamente para o PSD tornando-o o partido da máquina, apenas de orientação política diversa (o que não ocorreu, uma vez que o destino dos políticos da máquina varguista foi o PSP). Ou poderiam ir para qualquer outro partido (como aconteceu), mas deixando os poucos alinhados a Vargas no PSD - partido que então começaria esvaziado mas teria inclinação similar à que apresentava no resto do país: o varguista moderador, de centro, mais conservador. Nada disso aconteceu. Grande parte dos participantes do governo ditatorial de Getúlio foi para o PSP. E ainda assim, o PSD estadual acabou distante do varguismo. 


\section{O Partido Social Progressista (PSP)}

Parece, portanto, que ao menos fora do mundo urbano-trabalhista, não houve no estado de São Paulo nenhum desenvolvimento partidário dentro do espectro varguista. Ainda não pude apresentar a situação do trabalhismo no estado, o que farei mais à frente. Mas no que se trata do Partido Social Progressista, partido para o qual se dirigiu a maioria dos ocupantes dos cargos do Estado Novo em São Paulo, acho difícil afirmar que tenha sido um partido particularmente alinhado a Vargas. Não obstante tenha taticamente apoiado o próprio Getúlio nas eleições presidenciais de 1950, como veremos. De todo modo, o desempenho eleitoral do PSP no estado foi, de longe, o mais importante: a titulo de exemplo, cabe citar que dos cinco mandatos para o cargo de governador do estado que estiveram em disputa na democracia de 1945, Ademar conquistou dois, elegeu seu sucessor para um (Nogueira Garcez) e perdeu uma disputa para Jânio Quadros por apenas - é bom lembrar - 0,9\% dos votos válidos.

O PSP era o partido de Ademar de Barros, ex-interventor do Estado Novo em São Paulo. Nas exageradas palavras da biografia de Ademar, feita pelo correligionário Mário Beni (s/d:65), “Adhemar era todo o PSP”. Legenda criada por Ademar e sempre vinculada à sua imagem e às suas decisões políticas, a seguinte afirmação de Hélio Jaguaribe (1953:141) sintetiza com fidelidade essa interpretação mais comum sobre essa relação: “o Sr. Ademar de Barros é quem dá ao seu partido substância política, motivo pelo qual, em lugar de depender do partido, tem o partido na sua completa dependência". Efetivamente, Ademar havia criado o partido para servir como sua plataforma de campanha, uma vez que não estaria sendo bem quisto nem pelos pessedistas, nem pelos udenistas. Durante seus 3 anos à frente da interventoria do estado entre 1938 e 1941, segundo Regina Sampaio (1982:42), Ademar havia desagradado a 
elite local do ex-Partido Republicano Paulista através de, além de outros choques e desacordos, "substituir as velhas lideranças designando elementos jovens que, embora tendo ligações com o PRP e dispondo de algum prestígio na cidade [em cada município], não eram diretamente subordinados às lideranças tradicionais - tratava-se, ao que parece, de uma réplica, em microcosmo, da estratégia getulista”. E para a autora, seria essa a elite, desconfiada de Ademar também ao ter seus grandes nomes preteridos nos cargos de maior escalão, que formaria o futuro PSD e não abriria as portas da legenda para ele. Por outro lado, a radical UDN de São Paulo primeiro desconfiava de um político que havia aceitado tomar parte de modo tão integral da ditadura de Vargas. E depois, dentro de sua faceta de partido do anti-populismo brasileiro, tal como descrita por Dulci (1986), a UDN combatia o caráter populista desenvolvido no estado pela política ademarista.

Todavia, se o PSP era orientado à figura de um líder político personalista, nasceu também como um partido de grande organização em São Paulo. Nesse estado, como explica Sampaio (1982), acabou substituindo os pessedistas naquela herança do uso da máquina burocrática estadual do governo Vargas que era o padrão alhures. São Paulo não era apenas a única unidade federativa em que a máquina do Estado Novo iria gerar um partido diferente do resto do país, mas o único em que geraria um partido tipicamente estadual e, mais importante, o único em que geraria uma seção partidária estadual não alinhada ao varguismo. No entanto, antes de avançar sobre essa caracterização do posicionamento do PSP ao longo da democracia, é preciso entender alguns pormenores da formação do partido. Refiro-me especificamente ao fato de que é difícil imaginar que, no interregno de 1941 quando Ademar sai da interventoria até 1947 quando há a primeira eleição para governador, ele tenha automaticamente levado consigo o arcabouço de apoios, lideranças, alianças, favores e influências que construíra 
durante seu governo no estado. Afinal, são seis anos de intervalo em que os cargos estaduais estiveram nas mãos dos políticos que iriam formar o PSD paulista.

A explicação mais conhecida é a de Sampaio (1982), que coloca a conquista da eleição de 1947 como o divisor de águas que permitiu ao PSP desempatar essa disputa com os pessedistas pela herança da interventoria. Segundo afirma a autora, "mesmo para o PSD, organizado a partir da máquina da interventoria, a conquista do governo estadual afigurava-se como uma necessidade de consolidação de sua hegemonia" (p.51) e isso porque "a vitória nas eleições de 47 apresentava-se, assim, para o PSD, [...] como possibilidade de consolidação" (p52). Esse seria o mesmo motivo pelo qual, naquele ano, "a eleição de Ademar significou a possibilidade de estruturação do PSP em nível estadual, de forma a colocá-lo definitivamente como um interlocutor necessário no quadro da política paulista" (p.55). Em entrevista citada Por Fernando Henrique Cardoso (1978:51), Mário Beni, que era ainda um dos líderes do PSP, afirma que "é claro que o PSP quando elegeu o governador, não tinha a totalidade do estado de São Paulo, porque elegeu apenas 9 deputados. O PC fez 11, o PSD fez 26, mas o PSD vinha de um governo [...]".

Ora, é verdade que a vitória da primeira eleição democrática para governador foi central para fortalecer o partido de Ademar e, de resto, os partidos vitoriosos Brasil a fora. Um motivo óbvio para isso era o fato de que em São Paulo, as primeiras eleições para o cargo de prefeito dar-se-iam posteriormente, entre 1947 até 1954, dependendo do município $^{34}$. Ou seja, durante ainda cinco anos o governador eleito poderia indicar gestores municipais por nomeação. O mesmo Mário Beni (s/d), na biografia que escreveu sobre Ademar, primeiro narra a posição tomada pelo líder quanto a essa prerrogativa: "baixou o decreto [...] onze dias após sua posse como governador,

\footnotetext{
${ }^{34}$ O Decreto Lei ${ }^{\circ}$ 14.334, de 30.11.1944 estabelece um calendário diferenciado, no qual determinava a realização de eleições para os municípios do estado de São Paulo.
} 
exonerando os prefeitos nomeados anteriormente a 14 de março. Todos foram substituídos [...] Apenas foram mantidos os nomeados após aquela data, todos do PSP" (p.95). E depois analisa: "no firme propósito de engrandecer seu partido, foi nomeando seus correligionários para aqueles executivos [...] Germinou aí a semente daquele que seria o maior partido em São Paulo” (p.96).

Há também indícios concretos de que a vitória de Ademar inflou as bases partidárias do PSP. Sampaio (1982:112) comenta que "o PSP herdou as bases do PSD no interior do estado" e cita o depoimento feito por Paulo Lauro, um dos principais organizadores do partido ademarista, para quem "os velhos chefes políticos do estado, depois da vitória de Adhemar em 1947 [...] a maioria deles veio a formar nas fileiras do PSP: a evolução natural trouxe os homens do PSD para o PSP" (ibidem, nota de rodapé número 4). Além de que, na UDN paulista, teria havido também "uma dissidência [...] cujos componentes, rompendo publicamente com o partido em junho de 1947, ingressam no PSP, juntamente com vários prefeitos e vereadores udenistas” (p.58). De fato, analisando as migrações e as lealdades partidárias ao nível dos deputados federais, André Marenco dos Santos (2001:72) encontra que, para todo o período democrático de 1945-64, “o impacto produzido pela adesão de forasteiros adquire maiores proporções no Partido Social Progressista (PSP)". Ou seja, em um sistema partidário com alta taxa de lealdades perfeitas (membros que nunca haviam pertencido a outras legendas) ${ }^{35}$, de todos os partidos do país é o PSP quem mais recebeu políticos migrados de outras agremiações. E isso já no início do período democrático.

Por outro lado, se estou de acordo portanto que a vitória inicial de Ademar foi muito importante para a sobre-força de seu partido, tenho dúvidas de que se possa afirmar, tal como faz Sampaio (1982), que tenha sido um divisor sem o qual poderia o

\footnotetext{
${ }^{35}$ Cabe comentar, aliás, que o resultado geral encontrado pelo autor é muito interessante: a democracia de 1945-64 apresentava altíssimas taxas de lealdades perfeitas (membro de um partido que jamais pertenceu a outro), enquanto a democracia brasileira atual vem apresentando taxas muito inferiores.
} 
PSD ter igualmente se estabelecido como força hegemônica na herança da interventoria. Essa explicação esquece-se de dados que a própria autora apresenta: “já em finais de 47, o PSP contava com diretórios e sub-diretórios em todos os distritos eleitorais do interior e da capital e, nas eleições municipais realizadas nesse ano elege, sozinho, $27 \%$ dos prefeitos, contra $11 \%$ do PSD; 4,5\% da UDN [...]" (p.56). A força organizacional do PSP já na largada é patente: nas eleições do mesmo momento em que Ademar é eleito, portanto antes de poder usar as prerrogativas de seu cargo para montar uma estrutura que influísse nos resultados dos próximos pleitos, o partido encontrava-se já estruturado em todo o estado e ganhou mais do que o dobro de prefeituras do que o segundo colocado, justamente o PSD. Outro argumento básico para contestar a idéia de que seria a eleição de 1947 que consolidaria a legenda herdeira da burocracia do Estado Novo reside no simples fato de que, no resto do país, 9 estados tiveram governadores eleitos pela UDN, oposicionista e anti-varguista. E não consta que alguma vez se tenha dito que, por causa disso, as seções da UDN nesses estados tenham conseguido se estabelecer através da máquina estadonovista. Especialmente se considerarmos que duas dessas nove seções estaduais eram as do Rio de Janeiro e da Bahia.

Encaro de modo similar aquela sugestão tangencial de Campello de Souza (1977:79) que mencionei no começo deste trabalho: ao falar sobre o interventor que governou São Paulo nos cinco anos seguintes a Ademar, Fernando Costa, comenta que a ele "seguramente teria cabido o papel de contrapeso a Benedito Valladares no PSD. Morto aquele, Minas e Benedito deram a esse partido sua feição definitiva”. Ou seja, reconheço que esse tipo de evento inesperado tenha influência no decurso dos acontecimentos, mas certamente a seção estadual de um partido é maior do que a presença ou ausência da pessoa do interventor. Afinal, o que impediria a priori os outros membros próximos a Campos de construir uma seção forte no PSD paulista? 
Com isso admito, sem dúvida alguma, que a vitória de Ademar nas eleições para governador em 1947 tenha possibilitado o derradeiro fortalecimento da estrutura e da penetração organizativa do PSP em São Paulo. Mas creio que, não fosse sua constituição herdeira da força estatal anterior, pode ser que não tivesse nem iniciado o regime com tamanha estrutura e penetração e nem conseguido consolidar sua hegemonia apenas por uma vitória eleitoral. Então, como explicar sua força anterior e até mesmo sua possibilidade de uso da herança do Estado Novo? Antes de mais nada, estou de acordo com a caracterização feita por Fernando Henrique Cardoso (1978:50), para quem "de fato, o PSP foi criado, um pouco como o PSD nacional, a partir do aparelho estatal. Entretanto, ele expressou desde o início um fenômeno de ‘insubordinação paulista'; o chefe político do grande estado [...] não quis alinhar-se no grande partido clientelístico-estatal, de porte nacional que era o PSD” e não o fez logo de início, sendo que por isso teve de pagar "um preço para voltar a controlar a máquina estatal em 1947”. E mesmo Sampaio (1982), não é que discorde de que a máquina do Estado Novo já havia sido central para as primeiras formações do PSP. A autora apenas dá ênfase maior aos resultados das primeiras eleições para governador. Julgo necessário salientar que os quadros trazidos por Ademar para seu partido vêm já de antes de 1947, inclusive com membros participantes de outras interventorias que não sua.

Mas ao mesmo tempo, a constatação de que políticos de PSD afluíram para o PSP não prejudica a lógica do que proponho aqui. Antes, a reforça. Como afirmei anteriormente, o surgimento e consolidação do PSP em São Paulo como o partido para onde foi, em um ou outro momento, a maioria dos participantes da burocracia estadonovista no estado, revela que grande parte das "elites políticas" que aceitaram participar do governo local na ditadura de Vargas, mesmo assim não chegou a compor politicamente as fileiras das forças varguistas no momento da democratização. Esses 
políticos paulistas utilizaram-se da máquina do Estado Novo, mas não formaram partidos varguistas: nem o PSD paulista o era, nem muito menos o PSP de Ademar poderia ser assim considerado. Isso sem falar novamente na proximidade entre a UDN anti-varguista e o PSD em São Paulo e sobre as migrações massivas udenistas ao PSP nos últimos anos da década de 1940.

Porém, será mesmo que se pode classificar o partido e os posicionamentos políticos de Ademar assim tão rapidamente? Em linhas gerais, estou de acordo com a observação de John French (1988:1) de que a maioria dos políticos identificados como populistas causam um "perplexing paradox" similar: "while radical labor and the left hated them [populistas] as 'capitalist tools' who undermined worrking class movements, these same populists have been detested by industrialists and conservatives as incubators, if not instigators, of subversion". E tenho especial consciência dessas dificuldades, haja vista que poucos movimentos foram alvo de tanta discordância quanto à sua classificação como foi o caso da política feita por Ademar de Barros. Essa dificuldade é propalada certamente por causa das alianças díspares feitas por ele ao longo dos anos, como continua French: Ademar "eschewed any ideological or programatic emphasis in favor of whatever advanced his personal electoral, if not financial, interests. In a career spanning four decades, the pragmatic Adhemar could and did ally himself with Just about every group" (ibidem:2).

No entanto, creio que a literatura sobre o período permita identificar algumas características da política do partido criado pelo ex-interventor, para além dessa efetiva volatilidade no estabelecimento de alianças. Por um lado, tanto Beni (s/d) como Sampaio (1982) concordam que as bases do PSP no estado eram muito mais interioranas do que a capital. Tanto Francisco Weffort (1965) como Oliveiros Silva Ferreira $(1960,1964)$ avançam empiricamente em demonstrar que essas bases eram 
mais rurais do que urbanas, ou mais lumpen que modernamente operária. Não significa dizer que Ademar fosse fraco na capital ou nos centros de urbanização, mas seu movimento tinha mais apelo nos interiores rurais. Mas é intrigante recordar a sugestão de Lúcia Hippólito (1985) e de Lippi Oliveira (1973), para quem o PSD tinha por característica nacional penetrar exatamente nesse nicho político, e também o que fala Carlos Lacerda em seu depoimento: "mas havia também zonas de frieza, como, por exemplo, o interior de São Paulo, onde a UDN não entrava de jeito nenhum" (1978:106).

Quer seja quanto às suas bases, quer seja quanto a seu posicionamento no estado, o PSP paulista tinha algo de PSD e um quê de UDN em um hibridismo que é captado com maestria por Hélio Jaguaribe (1962:31):

\footnotetext{
em termos de sentido, o PSP é udenista na medida em que a UDN [...] é um partido que se consolida na vocação liberal-conservadora. Em termos pragmáticos, o PSP é pessedista na medida em que exprime, como o PSD, uma vontade de poder que se sobrepõe a quaisquer conotações ideológicas e programáticas.
}

Perfilo-me a essa interpretação precisa: o PSP tendia a posicionamentos políticos próximos ao que era típico da UDN, sendo apenas tão pragmático quanto o que se convencionou como sendo típico do PSD. Isso ajuda a entender como Ademar foi sempre figura de tão complicada definição. É certo que não era um varguista, embora tenha se aliado a Vargas em 1950 esperando receber a recíproca em 1955, quando pretendia substituir Getúlio na presidência. É verdadeiro, também, que era um liberalconservador e certamente não um esquerdista, a despeito de sua aliança com os comunistas em 1947 e em 1958. Em verdade, até sua participação na interventoria destoou de seu histórico. Como recordam Sampaio (1982) e Beni (s/d), Ademar começa sua carreira servindo nas forças contra-revolucionárias paulistas em 1932 contra o 
governo Vargas e, na seqüência, ganha destaque em sua carreira como deputado exatamente por seus posicionamentos e discursos radicais e fortemente anti-getulistas. Nomeado interventor, obviamente adere ao Estado Novo. Mas já no imediato momento da queda de Getúlio em 1945, inicialmente é procurado pelo PSD para perfilar o grupo próximo de Dutra no embate com os varguistas pessedistas (BENI, s/d). Não aceita e acaba preferindo a UDN paulista, do anti-varguismo intransigente.

É verdade que Ademar sabia das dificuldades que encontraria no PSD por causa das desavenças criadas com aquela parcela da elite política paulistas enquanto foi interventor. Nas palavras de Benevides (1981:237), “a adesão de Ademar de Barros à UDN, em 1945, decorreu de sua ruptura com os antigos setores perrepistas (não podia portanto ingressar no PSD)". Mas bem, chegou a ser convidado pelo partido. E além disso, se sabia que tinha motivos para não se achar bem vindo no PSD, também sabia que a UDN era pouco simpática a um político que tinha tomado lugar no governo Vargas e que ainda por cima começava a despontar como líder populista. E mesmo assim, entre as duas legendas, preferiu a UDN. Sampaio (1982) sugere, baseada em depoimento de Carvalho Sobrinho, que Ademar preferiu os udenistas porque dada a heterogeneidade dos anti-varguistas da legenda, poderia encontrar ali maior espaço de manobra política. Mas pergunto: mesmo que isso seja verdade, ainda assim não significa que, para Ademar e seu grupo terem optado pela UDN e sido aceitos ali, eram no mínimo pouco alinhados ao varguismo? Por certo que sim. Nenhum líder político disposto a cerrar fileiras com o varguismo optaria por começar a carreira na UDN de São Paulo, pois não.

E nesse sentido, pouco importa se a própria UDN paulista, segundo o depoimento de Luis Arrobas Martins dado à Benevides (1981:237), “não só rejeitou o Ademar como ainda se opôs a diversos outros membros da UDN de outros estados, que 
vindo aqui a São Paulo, através de entrevistas ou contatos pessoais, prestigiaram o Ademar [...] [a UDN] achava absolutamente impossível qualquer união com o Ademar". Afinal de contas, esse fato sempre levantado pela literatura (BENEVIDES, 1981; BENI, s/d; DULCI, 1986; SAMPAIO, 1982) aponta que o partido não via Ademar com bons olhos, mas não é capaz de negar que o próprio Ademar tenha escolhido inicialmente, entre suas opções, levar seu grupo ao partido radicalmente anti-Vargas.

É claro que, logo em seguida, após sair da UDN e formar seu PSP, Ademar de Barros não hesitou em primeiro se escorar no apoio dos comunistas em 1947, depois em buscar uma aliança com Vargas. A literatura é pródiga em apontar que o apoio dos comunistas teria sido de grande valia na vitória para o governo do estado. E a força inicial do PCB em São Paulo (LIMA Jr., 1987) sugere ser essa presunção realmente plausível. Ainda que, não custa lembrar, o mesmo apoio comunista tenha sido conseguido pelo PSP em 1958, segundo Ferreira (1960), e mesmo assim, como se sabe, Ademar tenha perdido a eleição à prefeitura da capital. Não se pode sobreestimar o peso do voto comunista angariado apenas pela indicação de apoio das lideranças, pois pode existir um hiato entre apoios dados por políticos e reflexo disso sobre as preferências do eleitorado, mesmo em se tratando dos eleitores comunistas. Mas ao mesmo tempo, não se pode subestimar um contingente eleitoral robusto como fora aquele que apoiara o PCB em São Paulo no começo do período democrático.

No entanto, é preciso ter claro que se Ademar aproximou-se dos comunistas e até mesmo do PTB, fez isso exatamente para disputar eleitoralmente a outra face do varguismo: o trabalhismo urbano, sindical, ligado aos institutos de previdência, aos movimentos populares urbanos. Aziz Simão apontara que o PSP, “apoiado pelo chefe comunista, teve oportunidade de iniciar a conquista de uma área eleitoral operária" (1956:140). Segundo French (1988:16): “Adhemar drew important lessons from the 
failure of the UDN's 'campaign of the white handkerchiefs", o que significou que "the experience of 1945 convinced him of the need to penetrate urban áreas, and he quickly realized that a radically new and pragmatic approach was needed to compete successfully in the urban electoral marketplace". Sampaio (1982:54) conta que:

\begin{abstract}
prosseguiram as tentativas de Adhemar no sentido de obter o apoio dos comunistas, ao mesmo tempo em que estes desenvolviam conversações com o grupo do Borghi [do PTB]. Os entendimentos entre o PTB e o PCB foram, contudo, prejudicados pela resistência de Vargas à candidatura borghista, bem como pela oposição de alguns dirigentes petebistas, que temiam perder os votos dos católicos. Assim, pouco antes de se encerrar o prazo para o registro dos candidatos, o Partido Comunista assume compromisso com o PSP.
\end{abstract}

O significado desse apoio, continua a autora, teria sido o de que:

\begin{abstract}
“a aliança com os comunistas e a própria divisão dos trabalhistas, da qual foi beneficiário, permitiu que o partido [PSP] penetrasse uma área eleitoral operária e adquirisse uma conotação popular que o levaria a se apresentar como partido de oposição às elites conservadoras identificadas com o PSD e, principalmente, com a UDN [...] e a disputar com o PTB o eleitorado trabalhista de São Paulo" (p.56).
\end{abstract}

Creio que esteja bastante claro na literatura em geral que há sensível exagero de Sampaio em dizer que o PSP se apresentasse como oposição às elites conservadoras. Mas certamente, há consenso no que se refere ao seu diagnóstico da disputa entre PSP e PTB. Benevides (1989:49) aponta que, ainda em 1951, "persiste a relação conflituosa [...] entre trabalhismo e ademarismo" e cita na seqüência um editorial do periódico O Jornal: “toda a política bandeirante está acondicionada em um barril de pólvora. Qualquer movimento em falso poderá ocasionar uma explosão de abalar toda a construção em que se assentam os dois principais partidos do Estado, PSP e PTB" (ibidem). Assinalar o avanço que o PSP pretendia sobre o eleitorado tipicamente trabalhista é muito importante, até para explicitar que a aproximação ao comunismo 
serviu de ponte para competir com o que seria a única vertente varguista no estado (dado que, como vimos, o PSD não estava alinhado desse modo). Mas ao mesmo tempo, isso não é contraditório ao que acabamos de ver, ou seja, que os núcleos principais de atuação do PSP estavam, desde o começo, no interior, no mundo rural paulista, ou mesmo no proletariado de tipo lumpen? E mais especificamente: não estava o PSP disputando, como disse acima, nichos eleitorais do PSD e da UDN?

Primeiro, no que se refere ao exagero de Sampaio sobre o PSP representar algo oposto ao conservadorismo só porque tentou disputar o voto trabalhista com o PTB, novamente encontro em uma interpretação de Hélio Jaguaribe a fórmula correta para dar conta desse ímpeto pessepista ao mesmo tempo em que se mantém no campo de disputa conservador. O partido de Ademar teria sido constituído "sob a tônica do populismo e parecendo a muitos que iria representar uma variante paulista do PTB" (p.30), e no entanto, "se tornou um partido conservador-liberal, embora mantendo suas características de movimento de massas" (p.31). Afinal, não é uma lei da natureza que um partido de massas e que conquista os trabalhadores seja de esquerda ou progressista, qualquer que seja o sentido que se queira dar a esses termos.

Em segundo lugar, suspeito de que os indícios da literatura no sentido da aproximação entre PSP e as bases de PSD e UDN sejam muito mais robustos do que a suposição de que PSP foi sempre o principal adversário do PTB na briga pelo voto do trabalhismo. Foi um concorrente relevante, sem dúvida, pois é fato que participou ativa e significativamente dessa disputa. Mas de início, nesse bolo estava também o PCB - e com vantagens. E posteriormente, como veremos, se os comunistas foram ilegalizados, por outro lado surgiram outras siglas menores e o trabalhismo paulista se fragmentou. $\mathrm{O}$ PSP continuou fazendo parte desse racha, ainda que com peso menor do que o que 
possuía no embate com PSD e UDN. De todo modo, parece, o PSP ajuda a enfraquecer os três partidos nacionais.

Mas se é verdade que o PSP almejava penetrar no eleitorado petebista e até mesmo imiscuir-se de soslaio entre as lideranças sindicais, não é correto imaginar que tenha sido sempre ferrenho opositor do PTB paulista nas urnas. Por mais de uma vez essas duas legendas foram aliadas nas disputas de nível estadual e ao menos uma vez se aliaram em nível nacional, quando da eleição de Getúlio. Os petebistas do estado estiveram sempre rachados em várias tendências discrepantes e, por certo, às vezes uma ou outra inclinava-se na direção do PSP. Não é difícil entender isso: o partido ademarista era, ao menos de início, a legenda mais vigorosa de São Paulo e parecia disseminada por todo o estado. Disputava os votos de PSD e UDN, mas intencionava competir também o trabalhismo para angariar uma base eleitoral urbana adicional, expandindo suas fronteiras. E isso a ponto de aliar-se aos comunistas, no que French corretamente identificou como: a disposição "to take great risks in pursuit of the main prize" (1988:16). Ora, fazia sentido que os petebistas tentassem pegar carona na estrutura partidária montada pelo PSP, já que enfrentavam, como explanarei mais à frente, uma variada sorte de dificuldades inclusive internas para consolidar sua seção paulista.

E se Ademar estabeleceu uma aliança com Getúlio em 1950, apoiando o exditador na eleição presidencial em troca de receber seu apoio para a sucessão ao cargo em 1954, não creio que essa aproximação tática levasse qualquer analista a caracterizar o grupo de Ademar exatamente como sendo pró-Vargas. Por um lado, isso já estava claro simplesmente na chapa à vice-presidência cuja indicação coube ao PSP. Não é à toa que Café Filho, o vice-presidente eleito pelo PSP, tenha exercido depois do suicídio de Vargas, segundo Pécaut (1990), um governo "sustentado pelos anti-getulistas". 
Benevides (1981:91) refere-se ao período dizendo que "no governo Café Filho [é] quando a UDN aparentemente 'está no poder"'. Efetivamente, demonstrei em outra ocasião que, ao menos do ponto de vista das nomeações ministeriais, o curto governo Café Filho foi dominado pela UDN e pelos opositores a Vargas (VASSELAI, 2009a). É claro que não se pode derivar das posições de Café Filho uma posição similar para todo o PSP ou para Ademar. Trata-se apenas de reforçar que, apesar da aliança eleitoral, tática, com Getúlio Vargas em 1950, as forças arregimentadas por Ademar não eram, de modo algum, varguistas. Por outro lado, isso fica ainda mais claro se levarmos em consideração simplesmente que uma aliança entre forças políticas diferentes, por óbvio é possível, e por óbvio não faz dessas forças similares.

A despeito de qualquer definição sobre a relação entre o PSP e o varguismo, o comentário de Benevides (1989:33) já bastaria para iniciar o ponto em que quero chegar: "se do ponto de vista dos partidos políticos a bipolarização em relação a Getúlio era a regra, no âmbito dos fenômenos populistas como o janismo e o ademarismo a questão era mais complexa [...] Movimentos suprapartidários, janismo e ademarismo jamais se definiram, de forma inequívoca, frente a Getúlio Vargas e sua herança". Ao menos no caso do grupo político que seguiu Ademar, estou propondo considerá-lo segundo aquela categoria frouxa que denominei no capítulo anterior como "nãovarguismo". Assumi desde o princípio a pouca definição do termo, propositadamente. A idéia não é discutir neste trabalho o conteúdo substantivo desses movimentos ou projetos políticos. Apenas tenho o interesse de identificar que, em São Paulo, o quadro político e partidário que foi se formando na democratização era basicamente dominado por grupos políticos distantes de Vargas. E que as elites políticas do estado que tomaram parte na burocracia da ditadura de 1937-45, diferentemente do que ocorreu no resto do país, em São Paulo utilizaram-se dessa maquina pública não para formar 
legendas de sustentação aos homens próximos de Getúlio. Caso único no país, esses variados grupos políticos geraram ali, na verdade, um PSP não-varguista e, mesmo assim, um PSD distante de Vargas e cada vez mais próximo dos anti-varguistas radicais da UDN. Além de tentarem tomar parte até mesmo de setores do movimento trabalhista.

\section{A União Democrática Nacional (UDN)}

Essa caracterização da União Democrática Nacional em São Paulo, que venho subsumindo como opositora radical de Vargas, não difere da imagem nacional que se faz do partido na literatura. Salvo uma ou outra seção estadual em que os udenistas aceitavam um pouco melhor a composição com outras forças políticas mais próximas de Vargas - e por isso eram mal vistos no núcleo da legenda - a UDN em geral era feroz combatente do varguismo (BENEVIDES, 1981). Quer seja esse varguismo entendido como projeto de Getúlio, quer seja entendido como aquela soma mais ampla que envolve o desenvolvimentismo posterior. Sabe-se que parte da UDN chegou a compor com o presidente Dutra, sucessor pessedista à queda de Vargas em 1945, no sentido de estabelecer um governo um tanto conciliatório e que bloqueasse o grupo político ligado a Getúlio, mas mesmo assim esse expediente gerou crises e fissuras internas na legenda (BENEEVIDES, 1981; LACERDA, 1978; DULCI, 1986).

E de todo modo, creio que nenhum analista negaria a caracterização dos udenistas como, na maioria das vezes, constituindo a aglutinação dos contrários diretos a Vargas. Para Benevides (1989:31) também a UDN fora uma "criatura de Getúlio", já que "reunindo esquerda e direita, só foi criada para derrubar Getúlio e vingar a ditadura estadonovista", a ponto de que, na frase famosa, "com a morte de Vargas, a UDN parecia uma polia sem correia". Guardado o provável exagero, uma vez que a UDN continuou identificando o varguismo mesmo depois do suicídio de Vargas, a idéia 
aponta bem o leitmotiv inicial da UDN. Nas palavras de um dos expoentes udenistas, Carlos Lacerda, a UDN "surgiu como uma conspiração. No começo ela era uma conspiração, não era um partido" (1978:30). Conspiração contra Vargas. Essa formação é descrita com precisão na sempre citada passagem de Lúcia Lippi Oliveira (1973:18), para quem a UDN ter-se-ia constituído por:

\begin{abstract}
elementos que não pertenciam ao governo e que se reúnem em torno da candidatura Eduardo Gomes [oposicionista ao governo Vargas]. Constituem uma verdadeira frente onde se encontram: os que não aceitaram a Revolução de 30; os que a fizeram e se sentiram traídos, tal como Eduardo Gomes; os que a fizeram e se desentenderam com o presidente (...), os que assinaram o 'Manifesto dos Mineiros' ${ }^{36}$, todos aqueles que por questões políticas e/ou pessoais não aceitavam a organização montada sob a Constituição de 37.
\end{abstract}

E ao que tudo indica, esse conglomerado político não era nada desprezível. Quer do ponto de vista de arregimentação de apoios, quer do ponto de vista do desempenho eleitoral. Quanto à sua estruturação, a situação da UDN fora diversa daquela apresentada por PSD e PTB: dentro daquela análise de Campello de Souza (1976), esses dois partidos nasceram com poder organizacional em situação de vantagem, dadas suas vinculações ao Estado Novo. Enquanto a UDN tinha de lutar para se estabelecer e se consolidar por fora da máquina governamental. Mesmo assim, a autora aponta que, ao se constituir da soma dos mais heterogêneos detratores do varguismo, a UDN conseguia assim atingir uma dimensão nacional e formava uma base de apoio de lideranças antigas e com cacife político respeitável em muitos estados. A análise de Gláucio Soares (1973) é um pouco diversa de Campello no que se refere ao quadro de formação partidária, mas ainda mais generosa na interpretação do que teria ocorrido à UDN. Para Gláucio, os

\footnotetext{
${ }^{36}$ Manifesto que marca o surgimento de oposição que rompia a censura a Vargas, em 1944. E que assim, acelerava a implantação da democracia.
} 
dois partidos que nascem em situação de vantagem na democratização foram exatamente PSD e UDN, não o PTB. Afinal, aquelas duas agremiações estavam presentes em quase todos os municípios e em todos os estados do país. Era o PTB a legenda que deveria ainda constituir-se nas muitas cidades em que a vinculação com sindicatos, com o Ministério do Trabalho ou com a estrutura previdenciária era inócua.

E se a UDN nasce com porte respeitável em relação à constituição de seus quadros e de sua organização partidária apenas somando opositores a Vargas, encontrou também no eleitorado uma abertura bastante considerável às suas propostas antivarguistas. Afinal, no resto do país o partido nasce, sabidamente, como a segunda força política nacional do ponto de vista dos resultados eleitorais. Atrás do PSD e à frente do PTB. E mesmo que se somem os desempenhos dessas duas legendas, ainda assim o papel desempenhado pela UDN no início democrático - e mesmo em todo o resto do período - desaconselha imaginar que os críticos de Vargas não obtivessem apoio popular. Ou seja, o anti-varguismo tinha fôlego organizacional e também eleitoral aliás, cabe ressaltar esse aspecto pouco lembrado pela literatura sobre o período.

A história é escrita pelos vencedores e isso pode obscurecer o desempenho udenista nas urnas: não se pode interpretar que a democracia de 1945-64 fora um período puramente varguista, enquanto a UDN com seu discurso de antítese angariou nunca menos de $30 \%$ dos votos à presidência da República e uma média de $24 \%$ dos votos à Câmara Federal. Afora o fato de que o sistema eleitoral não previa segundo turno: quem pode garantir que, em 1955, Juscelino Kubitschek (PSD-PTB) com 35\% dos votos contra $30 \%$ de Juarez Távora (UDN-PDC) teria de fato representado a preferência da maioria absoluta em um hipotético segundo turno? Ou que os $25 \%$ de votos de Ademar de Barros não teriam possivelmente migrado mais à UDN do que ao construtor de Brasília? Conjecturas à parte, é fato que o presidente Bossa-Nova ganhou 
da UDN por apenas cinco pontos percentuais de diferença e com apenas um terço da preferência nacional. Diga-se de passagem, nem o próprio Getúlio conseguiu atingir maioria de votos em 1950, embora ficasse próximo, com 48\%, enquanto a UDN cravava relevantes $30 \%$ com o brigadeiro Eduardo Gomes.

Dentro de seu anti-varguismo empedernido, a UDN trazia facetas específicas que vale a pena ressaltar. Os udenistas foram os homens críticos de Vargas, críticos do desenvolvimentismo das décadas seguintes, críticos dos seguidores da Carta Testamento. Combatiam a intervenção estatal na economia. E tinham, ainda, forte discurso anti-populista (DULCI, 1986) e moralizante (BENEVIDES, 1981). Sobre o primeiro, Otávio Dulci estabeleceu um marco interpretativo ao colocar a UDN como a legenda que combatia o estilo ou a prática política dos líderes personalistas que se utilizariam das massas populares como fator de apoio ou fator de mobilização. Apesar das intrigantes sugestões de McCann (2003), por exemplo, de que o próprio Lacerda representaria uma tipo de populismo de classe média, importa entender o que os próprios udenistas viam como populismo. E o populismo, para os udenistas, era nesse sentido uma perversão do espírito da política liberal: invertia a ordem de influência entre Estado e sociedade de um padrão bottom-up para top-down. Avalio que seja essa a brecha, diga-se de passagem, para o florescimento do aparentemente contraditório golpismo em meio ao apelo liberal da UDN. A democracia de 1945 foi sendo crescentemente desacreditada pelos udenistas especialmente porque, dado o populismo, parecia estar com seu funcionamento mais básico pervertido. Afinal, o populismo manipularia a massa, determinando-a e assim impedindo que ela, massa popular, determine a política.

Já no que se refere ao moralismo udenista, Benevides (p.215) afirma tratar-se de: "um elemento comum, de forte centralização, que sempre seduziu as classes médias, 
mergulhadas em suas frustrações e perplexidades: o moralismo (combate à corrupção administrativa) aliado ao anticomunismo (pavor de uma suposta 'proletarização igualitária'). Segundo Lacerda, “a UDN era, predominantemente, o partido da classe média, que se batia pela moralização dos costumes; que era uma projeção, no tempo, do que fora o tenentismo das antigas revoluções. Um partido ruibarbosiano, no que tudo isso quer dizer de retórica, de eloqüência, de ideologia liberal" (1978:153). Admito algum exagero nessa caracterização liberal defendida por Carlos Lacerda e tampouco creio que se possa confundir o moralismo com o liberalismo, ainda que se tangenciem. Mas deixo essa discussão para mais à frente. Assim como deixo para a seqüência final deste capítulo a discussão mais pormenorizada dos caracteres, no moralismo, de defesa da purificação da prática administrativa, de crítica do uso da máquina estatal no processo político, até de negação da política em prol da técnica, como veremos. Neste momento, o que importa reter é apenas um desses aspectos mais gerais que, creio, está bem delimitado na seguinte afirmação de Benevides (1981:267): “em termos concretos, o moralismo da UDN consistia em fazer da denúncia à corrupção administrativa ('a caça aos escândalos') a razão de ser da luta oposicionista, sobretudo na década de 50, com o objetivo de "demolir o getulismo e sua herança"”.

Em São Paulo, sabe-se, a UDN foi dos três principais partidos aquele que pior desempenho atingiu do ponto de vista de sua organização e até mesmo eleitoral. Mesmo assim, porém, é verdade que, segundo Benevides, "a UDN paulista, eleitoralmente fraca, $[. .$.$] era forte em termos de 'notáveis' remanescentes do Partido Democrático, do$ Partido Constitucionalista e da União Democrática Brasileira, de Armando Salles Oliveira" [...] além de dissidência do PRP” (1981:236). E segundo entrevista de Oswaldo Trigueiro à autora (p.167), "sem dúvida, o diretório nacional da UDN estava sujeito à influência da UDN da Guanabara e de São Paulo, onde ela era mais 
intransigente". Certamente isso permitia à fraca seção paulista do partido ter um papel relevante por exemplo na radicalização do discurso e das posturas do partido, mas como já citei no capítulo dois deste trabalho, a própria autora comenta que "os representantes parlamentares [...] detêm então, maior parcela de poder dentro do partido. Um dirigente udenista sem mandato legislativo perdia muito de sua força e prestígio" (1981:176). O que significa dizer que poucos udenistas de São Paulo conseguiam essa influência, já que, como vimos, os votos conseguidos pelo partido no estado ficavam muito abaixo de sua média nacional.

De todo modo, a constatação do radicalismo da UDN em São Paulo soa bastante condizente com o que em geral se afirma sobre aquela seção estadual do partido. E de fato, faz sentido: a oposição a Vargas, os críticos do varguismo e os grupos distantes do ex-ditador, todos esses se dividiram muito mais em São Paulo do que em qualquer outro estado do país. À UDN do estado foi confluindo o grupo mais radical desse espectro. Não que aquele padrão udenista de outros estados não se mantivesse, pelo contrário: também ali nasceu na esteira de conglomerar os políticos anti-varguistas e disputar parte dos não-varguistas ${ }^{37}$. Mas exatamente por isso caracterizou-se ali pelo radicalismo: a UDN paulista, em sua formação mas também ao longo do período, teve de competir as lideranças e o espaço anti-varguista e não-varguista de um modo sem paralelo nos outros principais estados da federação. Disputar um espaço em que estava desde o início um PSD pouco varguista, mas especialmente, um PSP robusto. E espaço no qual surgiu até a mesmo a concorrência de um PDC ascendente. A lógica esboçada pelo depoimento de Arrobas Martins à Benevides (1981:213) é lapidar:

se a UDN fosse realmente o partido da classe média ela teria uma expressão muito forte aqui em São Paulo. Quer dizer, nem mesmo a classe média estava na UDN. A maioria dos udenistas pertencia à classe média, mas a maioria da

\footnotetext{
${ }^{37}$ Nos outros estados, divida as lideranças não-varguistas com os partidos menores e às vezes com seções do PSD.
} 
classe média não era udenista. A classe média estava muito dividida entre PSD, PSP, UDN. A principal força do PSP creio que era, também, a classe média

Em tal contexto, à UDN foi-se delimitando apenas um espaço diferencial de atração de lideranças para a formação partidária: o espaço dos opositores mais radicais ou mais ideológicos (no sentido de menos abertos ao pragmatismo) que não conseguiam compor com o PSP promissor, ou dos que julgavam o PSD menos aberto à oposição dura a Vargas do que o ambíguo PSP. Fora, é claro, aquela parcela tradicional caracterizada por Carlos Lacerda, nas palavras que mencionei no capítulo anterior, para quem o partido “depois começou a ser articulado em São Paulo, através das ligações com o Julinho [de Mesquita Filho] e com o pessoal de lá. Mas o grupo de São Paulo, do Partido Democrático, tinha aos nossos olhos um matiz muito reacionário [...]" cuja posição era "muito conservadora, muito regional. Combatiam o Getúlio menos pelos efeitos maléficos que ele pudesse ter nacionalmente, do que pelo fato de que aos paulistas a Revolução de 30 soou como uma tentativa de destruir a influência de São Paulo na federação, o que realmente aconteceu" (1978:31).

Dado cenário que descrevi em relação ao PSP e ao PSD paulista, não é difícil imaginar a concorrência em relação a esse público alvo de lideranças a serem filiadas ao partido. Ou seja, do ponto de vista de sua constituição inicial, é fácil entender porque a UDN paulista não foi, em São Paulo, aquele conglomerado que unia todos ou quase todos os opositores ao regime de Vargas e também atraía boa parte dos não-varguistas. Conglomeração anti-varguista que, como acabamos de ver, seria tanto o que fazia a UDN do resto do país nascer robusta organizacionalmente quanto concentrar os votos dados aos candidatos de fora da linha de alianças varguista. Em São Paulo, até mesmo o PSD estava repleto de lideranças com tal inclinação política - em nível muito maior do 
que acontecera em outros estados, como disse anteriormente. E mais importante: o PSP de Ademar representava um partido não alinhado ao grupo de Vargas e ambivalente o bastante para assegurar espaço até mesmo aos opositores desse. Com um diferencial: o PSP havia nascido herdando e se apropriando da estrutura política do governo estadual da ditadura de Vargas. Para políticos que em outros estados talvez constituíssem possíveis quadros para a UDN, era a chance de entrarem, em São Paulo, em um partido que se originava já fortalecido: o PSP foi o único partido não-varguista advindo da máquina do Estado Novo no país. Além do que, como comentei, Sampaio (1982) acusa inclusive a forte migração posterior de udenistas em direção ao PSP, no que levavam consigo mandatos de prefeitos e vereadores por todo o estado.

E a fragmentação do anti-varguismo e do não varguismo manifesta-se até mesmo na formação de outras legendas menores, como é o caso do PDC - o "maior partido pequeno" do país (VIANNA, 1978:29). Para Benevides (1981:217), "pelo critério de origem parlamentar, o Partido Democrático Cristão teria sido, talvez, o típico partido de classe média". Um partido das "mãos limpas", que segundo Fernando Henrique Cardoso estaria muito próximo do moralismo de classe média da UDN, mesmo antes do fenômeno janista (1978:53). No mais importante trabalho sobre o PDC, Werneck Vianna apontava que a legenda cristã, no Brasil, "quando muito, veio a representar o ritualismo moralizante de certos círculos das camadas médias de alguns centros urbanos de São Paulo e Paraná, partindo de vocação reformista e anti-estatista [...] ; seria uma 'UDN católica"”. Ou, segundo Benevides, uma "UDN confessional" (1981:228). Embora não se possa afirmar que o PDC tenha tomado lideranças políticas da UDN os primeiros momentos da democratização, é certo que foi dividindo os políticos opositores ao varguismo à medida em que se formou e se fortaleceu. Para Vianna, o PDC no Brasil não representou, como em sua origem na Europa, um partido 
reformista moderno. E enquanto nesses países a Igreja pôde colocar-se fora da política enquanto a disputava formalmente via partidos cristãos, no Brasil optou por não fazê-lo e manteve-se todo tempo ao redor do poder. Mas a despeito do significado da democracia cristão no país, não resta dúvida de que participou na fragmentação dos anti-varguistas de São Paulo. Ainda que caia na tentação de tentar adivinhar as preferências eleitorais, Gláucio Soares recorda o que no fundo a literatura e os analistas de época jamais discordaram: "o PDC recrutou principalmente eleitores que seguiam, ou pensavam seguir, uma orientação característica dos clássicos partidos liberais e que poderiam ter dado seus votos à UDN" (1973:38).

É claro que se poderia objetar se o próprio surgimento e moderado crescimento do PDC em São Paulo não teve espaço exatamente pela debilidade da UDN no estado. Para meu argumento, importa menos perceber que a estrutura organizativa da UDN não se fez sólida o suficiente para impedir o crescimento do PDC. O mais interessante é salientar, por um lado, o quadro de fragmentação dos não-alinhados ou dos opositores ao varguismo. O espaço dos não-varguistas não apenas ficou um tanto saturado como, principalmente, houve a opção mais forte do único partido distante de Getúlio que pôde beneficiar-se da máquina administrativa do Estado Novo. Pode ser que à UDN paulistas, em linhas gerais, acabaram por dirigirem-se políticos ideologicamente mais radicais, que não podiam encontrar em outras legendas a vocalização de suas críticas nos decibéis que gostariam, ou políticos, é claro, que preferiam a UDN por identificação programática. Esses, que hoje talvez fossem taxados de principistas, eram ideologicamente afinados ao udenismo a ponto de não cederem às possibilidades mais pragmáticas. Não é à toa que Benevides identifica tantos udenistas desse tipo pouco flexível entre as seções paulistas do período. E menos ainda, certamente não é à toa o 
predomínio dos "bacharéis" da UDN na sua vertente paulista (BENEVIDES, 1981). Bacharéis, como se sabe, foram os udenistas acadêmicos, formais, ideólogos do partido.

Por outro lado, o fato de uma disputa pelas lideranças ter tomado conta de tantos partidos a ponto de fragmentar o não-varguismo e o anti-varguismo é digno de nota por um segundo motivo. De fato, boa parte das opções político-partidárias em São Paulo afastava-se dos grupos tradicionalmente próximos de Vargas no resto do país. Parece que, de algum modo, a pouco estudada relação dos paulistas com o Estado Novo e dos paulistas com o varguismo teve efeitos, no mínimo, na formação das forças políticas inicialmente colocadas em disputa quando da redemocratização. Mas resta saber qual era, nesse cenário, a situação do trabalhismo naquele que foi sempre o estado mais urbanizado, industrializado e, por suposto, modernizado da nação. Afinal, esse era um outro flanco no qual o varguismo se perfilava.

\section{Partido Trabalhista Brasileiro (PTB)}

O conhecimento estabelecido sobre a formação do Partido Trabalhista Brasileiro no país é bem sintetizado pela descrição de Fernando Henrique Cardoso, para quem "a máquina petebista superpunha-se à do Estado; eram políticos profissionais, funcionários da Previdência Social e do Ministério do Trabalho, sindicatos do PTB” (19981:49). O sentido de criação do partido é lembrado por Benevides (1989:9): “foi criado por Getúlio Vargas para, segundo suas palavras, 'servir de anteparo entre os sindicatos e os comunistas". Afinal, segundo Lucília Delgado (1989), o PTB vinha do queremismo e Vargas temia o PCB porque esse partido e seus movimentos sociais não dependiam do varguismo. Enquanto na interpretação de French (1988:6), "in slashing attacks on his enemies, Vargas issued a dramatic call to Brazil's industrial workers, urban laborers, and employees to actively enter the political arena in defense of their interests through 
his newly founded PTB”. Ou seja, a criação do PTB era também um artifício através do qual Getúlio tentaria precaver-se de uma possível retomada oligárquica daqueles que se opunham a seu governo e que lhe haviam arrancado do poder. E como se não bastasse a origem do partido estar vinculada a setores da burocracia estatal nacional e à maioria dos sindicatos, Getúlio ainda "had to unilaterally alter the terms of the upcoming election" (ibidem), através de expedientes institucionais importantes: "Vargas maintained the literacy requirement for suffrage, which discriminated against the rural population, while making voting oligatory for virtually all literate Brazilians [...] Even more importantly, the new law established an ex-officio group voter registration procedure specifically designed to favor urban areas".

Campello de Souza (1976) apontou o conjunto desse processo de formação do PTB e concluiu que, nascendo como um partido da máquina, tinha seu potencial de desenvolvimento estabelecido logo de início pela vantagem organizacional herdada. Jás Gláucio Soares afirmava que o PTB nascera frágil em comparação com PSD e UDN exatamente porque não tinha estruturação similar: por mais que os trabalhistas adviessem da máquina governamental ligada ao mundo do trabalho e da indústria, isso restringia o lócus de ação do PTB a poucas cidades e centros urbanos, enquanto PSD e UDN apresentariam estrutura robusta por praticamente todo o território nacional. Ao PTB teria cabido, na verdade, um crescimento posterior à formação da democracia e ligado sobretudo ao avanço estrutural da modernização, industrialização e, principalmente, urbanização. Quer seja por ter iniciado o regime com uma organização partidária de monta, quer seja por mudanças sócio-econômicas na estrutura produtiva e urbana do país, é fato que o PTB tornou-se o grande partido que mais crescia ao longo da democracia de 1945, enquanto UDN se mantinha e PSD perdia espaço em nível 
nacional. E ao mesmo tempo ${ }^{38}$ em que cresceu, o PTB foi-se tornando mais progressista, mais esquerdista ou mesmo mais radical dentro de um sistema crescentemente polarizado (FIGUEIREDO, 1993; SANTOS, 1986).

Se a preocupação original de Vargas era capturar os movimentos urbanos e trabalhistas que de outro modo escapariam à dependência do varguismo, tal como Delgado (1989) sugeriu e como de fato ocorreu no país através da criação do PTB, no que se refere à situação do partido em São Paulo o livro de Benevides (1989:16) parte exatamente da indagação: "para este caso específico do PTB paulista, até que ponto petebismo é sinônimo de getulismo?". Vale lembrar que, por vias tortas, essa é exatamente a indagação que fiz para o PSD paulista. Do ponto de vista de sua origem, o PTB nasce no Rio e no Rio Grande do Sul. O jornal "A Noite" noticiava a primeira Convenção petebista como sendo o nascimento de um partido "fundado por um grupo de líderes trabalhistas do Distrito Federal” (apud DELGADO, 1989:86), enquanto, por sua vez, “o programa definitivo do Partido Trabalhista Brasileiro, a nível nacional, sistematizaria e consolidaria as propostas do PTB do Rio Grande do Sul” (DELGADO, 1989:38). Faz sentido que, no caso do PTB, Benevides sugira ter havido "o PTB hegemônico no Rio Grande do Sul, o PTB paradoxalmente fraco em São Paulo e o PTB ‘carismático' do antigo Distrito Federal” (p.15).

A expectativa de que em São Paulo formar-se-ia um movimento trabalhista especialmente pujante segue a lógica esboçada por Aziz Simão, para quem "o ano de 1945 marca a entrada em massa dos operários na disputa eleitoral e o peso de seus votos na decisão dos pleitos" (1956:133). O autor sugere em um dos primeiros estudos do voto feitos no Brasil, que nos primeiros pleitos da democracia de 1945 teria havido concreta identificação entre áreas de concentração operária e os votos recebidos pelo

\footnotetext{
${ }^{38}$ Não custa advertir que o uso da expressão "ao mesmo tempo" é proposital: não pretendo assumir nenhuma linha de causalidade entre um processo e outro, ou seja, entre fortalecimento do PTB e a polarização do regime, ou entre crescimento do PTB e suas possíveis inclinações políticas.
} 
PTB e pelo PCB paulistas. Também as primeiras interpretações sobre o período, como a clássica leitura de Gláucio Soares (1973, 1981), não deixaram de salientar a identificação entre o PTB e as classes trabalhadoras, ou entre o partido e os setores urbanos. Para Soares, a tal ponto haveria uma identificação crescente entre o PTB e suas bases sociais, que não seria possível compreender seu crescimento eleitoral ao longo da democracia de 1945 senão pela expansão da urbanização.

Um indício dessa vinculação social estaria, segundo ele e muitos outros, no fato de que parte do crescimento ao menos inicial do PTB teria sido consequiência da ilegalização do Partido Comunista Brasileiro (PCB) em 1947 (SOARES, 1981; CARDOSO, 1981; BRANDÃO, 1997). O PCB era um partido que começava forte em São Paulo: observando novamente os dados que apresentei no capítulo dois, é possível reparar que os votos obtidos pelo partido em eleições legislativas no estado estavam bastante acima do estatisticamente esperado. Mas o PCB era ele mesmo, na verdade, uma outra possibilidade pela qual os movimentos operários paulistas poderiam ter gerado vias de inserção na política do país. De fato, não faltam indicativos do sucesso inicial do partido no estado. Segundo Cardoso (1978:46), "basta lembrar que o PC tinha maioria de representantes na Câmara Municipal de São Paulo quando ocorreram as cassações subseqüentes à decisão de torná-lo ilegal. A mesma tendência ocorreu em outras cidades mais industrializadas”. Segundo Lima Jr. (1983:49), "nas eleições para a Assembléia Constituinte, em 1945, e nas eleições estaduais de 1947, o partido revelou sua força, que, a nível regional, estava principalmente localizada nas duas maiores cidades do país, Rio de Janeiro e São Paulo. Nas eleições de 1947, elegeu 46 deputados em quinze dos vinte e um estados". E de acordo com French, nas eleições de 1945, "the PCB's presidential candidate Yedo Fiúza came in first in the legendary "red port" city of Santos, tied for second place with Brigadeiro Eduardo Gomes of the National 
Democratic Union (UDN) in the capital, and beat the UDN's candidate in both the textile city of Sorocaba and the ABC region" (1988:8).

No total do país, os comunistas conseguiram $8,6 \%$ dos votos para a Câmara Federal na primeira e única eleição que disputaram em nível nacional. Para se ter uma idéia, isso representava a quarta maior votação, logo atrás dos $10 \%$ de votos do PTB. Esse tipo de desempenho, se mantido ou ampliado, poderia vir a configurar o PCB como um partido de importante desempenho nacional e que tinha, ao mesmo tempo, sua principal base de sustentação em São Paulo. É evidente, contudo, que não se pode conjecturar o que teria acontecido se os comunistas continuassem colocando à prova das urnas seu prestígio junto aos trabalhadores. Em 1947, “teve, primeiro, seu registro cancelado pela Justiça Eleitoral e, em seguida, os mandatos de seus parlamentares cassados por decisão do Congresso" (Lima Jr., 1983:49). Para Cardoso (1978), a ilegalidade do PCB afetou e muito a possibilidade de representação classista em São Paulo e colocou os trabalhadores como eleitorado a conquistar. Afinal, como bem apontou Gildo Marçal Brandão (1997), a ilegalidade política de uma legenda não fortalece sua mobilização política revolucionária, como parte das lideranças de esquerda chegaram a bradar - na verdade, antes mata a atuação política e a influência política direta e formal de seus líderes, que são obrigados a buscar outras legendas.

Mesmo em se assumindo que as lideranças do PCB tenham migrado para outras legendas - por suposto da literatura em geral, em grande parte para o PTB - o encerramento das atividades formais e explícitas do partido pôs um fim em uma legenda que concentrava votos em São Paulo. E que parecia promissora quanto à sua possibilidade de influir nos rumos nacionais - quer por ter conseguido um desempenho eleitoral inicial admirável, quer porque seu radicalismo e também o cenário internacional a colocassem como interlocutora óbvia nem que fosse pela via da negação. 
Diversos autores, tal como Soares $(1973,1981)$, extrapolam com algum exagero o raciocínio da incorporação de lideranças comunistas pelo PTB à idéia de que também os votos comunistas teriam migrado aos trabalhistas. Mas mesmo que fosse integralmente verdadeira, acontece que, se essa migração do eleitorado ocorreu, é difícil sustentar que tenha ocorrido em São Paulo. Pelo simples motivo de que a votação do PTB no estado decresceu em termos relativos. Como vimos no segundo capítulo, o peso do estado na votação total do partido foi sendo reduzida e, mais importante, sua magnitude de votos ali passou a ser cada vez mais discrepante (para baixo) do que atingia no resto do país. No que se refere à Assembléia Legislativa de São Paulo, o PTB chegou a decair sua porcentagem de votos: de $20 \%$ do total em 1947 para $16 \%$ na eleição seguinte.

Se é verdade que o rápido progresso industrial e a expansão urbana de São Paulo faziam da capital do estado, e quiçá do próprio estado, os lócus ideais de desenvolvimento dos partidos populares de esquerda, não resta dúvida de que a ilegalização do PCB abortou uma possibilidade partidária legítima e plausível. Daí a saber se esse partido, mesmo forte em São Paulo, seria nacionalizável a exemplo dos outros três grandes, é matéria de pura especulação. Mas de qualquer modo, a idéia de que os votos do PCB migraram ao PTB é uma recorrência. E se a relativizarmos, coloca-se a questão de que, se a ilegalidade dos comunistas colocou à deriva um eleitorado supostamente cativo, como veremos a seguir nenhum partido paulista conseguiu conquistá-lo em definitivo.

Mesmo sendo um partido advindo da máquina federal e ao mesmo tempo um partido com possibilidades de expansão em bases sociais sólidas, o PTB nunca alcançou em São Paulo o desenvolvimento político pujante que a crítica esperava. O diagnóstico mais comum sobre a situação do trabalhismo no estado é similar ao de Delgado (1989:76), segundo o qual realmente “o PTB nunca chegaria a ser forte no estado de 
São Paulo, apesar de seus filiados controlarem, nesse estado, várias instituições públicas federais como os Institutos de Previdência e as Delegacias Regionais do Trabalho". E Benevides vai além e julga que: "PTB paulista foi, como sabido, eleitoralmente fraco, politicamente desarticulado e ideologicamente inconseqüente” (1989:9). É claro que PTB fraco não é o mesmo que distante do varguismo. Sobre isso, continua a autora:

Em certos estados, a identificação do PTB com os trabalhadores urbanos como no Rio de Janeiro - e com a tradição getulista - como no Rio Grande do Sul - era facilitada por óbvias raízes históricas e pela competição restrita no campo do trabalhismo [...] Em São Paulo a situação era bastante diversa. O trabalhismo, como expressão partidária e 'ideológica' permanecia alvo de constante disputa, no plano eleitoral e na luta sindical. O PTB paulista, mesmo no seu período mais articulado, nunca pôde se arvorar em 'dono do trabalhismo' e tampouco em líder inconteste do movimento sindical. O janismo e o ademarismo não repudiavam Getúlio e também eram 'do povo'; os comunistas [...] controlavam boa parte dos sindicatos [...] e a 'família trabalhista' incluía aqueles pequenos partidos [PTN, PST]” (1989:18).

O racha partidário no embate pelo movimento trabalhista e sindical é invariavelmente apontado como um dos fatores determinantes para entender como o PTB de São Paulo não chegou a ser uma legenda realmente forte a despeito de haver, no estado, o maior e mais diversificado mundo sindical. É absoluta verdade que ao lado do PTB, os trabalhadores eram disputados pelos comunistas, pelos partidos trabalhistas menores que foram surgindo, como PTN e Partido Social Trabalhista (PST), pelo PSP de Ademar e até mesmo pelo PDC. Mas se é uma verdade absoluta, trata-se de uma explicação apenas relativa. Porque se é óbvio que essa fragmentação enfraqueceria o PTB, ela ao mesmo tempo precisa ser explicada: quais motivos levaram o trabalhismo mais especificamente getulista a não conseguir monopolizar os movimentos sindicais e urbanos tal como fizera em outros estados? Afinal de contas, no restante do país as seções do PTB disputavam no máximo com os comunistas e, mesmo assim, foram 
beneficiadas pela ilegalização do PCB em 1947. O que fazia com que o trabalhismo getulista desse espaço ao surgimento de tão numerosas e até mesmo tão poderosas forças concorrentes em São Paulo?

Talvez isso tenha a ver com a segunda explicação já clássica para a debilidade eleitoral do PTB no estado: aquilo que Benevides (1989:21) chamou de "conspiração gaúcha”. E que é assim explicada por Cardoso (1978:46):

posto à margem o $\mathrm{PC}$, os outros partidos populares sabiam que o eleitorado que ele representava ou sobre o qual influía, acabaria por engrossar suas legendas. Por outro lado, e este fatos deve ter pesado mais do que o anterior, havia interesses nacionais, no caso do PTB, que contrariavam as tendências favoráveis à constituição do trabalhismo por Getúlio Vargas e depois por João Goulart, requeria na luta interna do PTB, uma seção paulista relativamente fraca. Ela era minada, ainda mais, pelo empreguismo e pelo tráfico de influências que, na linguagem jornalística ficou conhecido pela expressão "fisiologismo", que foi a marca da tendência dominante no PTB paulista, que se acomodou nos quadros de um partido clientelístico mais do que de um partido de massas.

O mesmo é dito por vários dirigentes do PTB da época, em entrevistas ao CPDOC-GV. Uma reunião dessas impressões está em Benevides (1989:22-3): para Alzira Vargas do Amaral Peixoto, presidente da legenda em São Paulo mais de uma vez, “O PTB de São Paulo foi trucidado. Nunca o PTB nacional deu recursos, nunca ajudou, nunca facilitou a vida". José Gomes Talarico confirma que a fraqueza do PTB paulista era "proposital”. E Jorge Duque Estrada vai além:

Dr. Getúlio, por contingência de caráter político-econômico, era obrigado a nos contes. Éramos uma espécie de carne para leão. Ele tinha que amansar os leões de São Paulo e nós éramos o filet mignon. Os leões eram os grandes industriais, a Federação das Indústrias do Estado de São Paulo (FIESP). Nos confundiam com os comunistas. Greve, tomar fábrica, etc. Getúlio tinha que contentar a Igreja, os industriais, os paulistas quatrocentões, a ala rural (apud BENEVIDES, 1989:23). 
Exemplo cabal desse temor deu-se logo na origem do PTB de São Paulo, quando do rápido fortalecimento da campanha de Hugo Borghi à candidatura para o governo do estado. É difícil medir a força eleitoral de Borghi àquela altura e sem o auxílio de pesquisas eleitorais, mas certamente é plausível que Getúlio temesse por uma liderança política que se mostrava cada vez mais capaz de angariar apoios e que tornava-se paulatinamente a opção inconteste do PTB de São Paulo para aquele início de democracia (SAMPAIO, 1982). A pressão exercida pela executiva nacional do partido fora a tal ponto incisiva que Borghi sairia candidato a governador por outro partido: o PTN. O que indica desde já um dos movimentos que iria explicar o fortalecimento de outros partidos trabalhistas menores: o esfacelamento paulatino de quadros importantes do PTB. Borghi havia sido o líder do movimento "queremista" e o responsável pela campanha que taxou contra o candidato à presidência da UDN, em 1945, a idéia de elitismo - consubstanciada na falácia de que o udenista Eduardo Gomes teria feito pouco caso dos votos dos "marmiteiros".

Mas os descontentamentos da cúpula petebista nacional para com as movimentações políticas de Borghi começaram já nessa mesma campanha presidencial de 1945. O líder paulista foi dos principais apoiadores da candidatura Dutra pelo PSD e defensores do apoio do PTB paulista a Dutra. Essa decisão ia contra as recomendações de Getúlio à época, de que o PTB deveria indicar candidato próprio, segundo Delgado (1989). No entanto, o problema maior não residia nas opções políticas de Borghi, se comparado ao cenário mais amplo que a autora descreve no que se refere a sua relação para com a cúpula varguista do PTB nacional: "a obstinação e incansável militância de Borghi poderia se transformar em uma ameaça velada, a médio prazo, à própria influência getulista em um estado que possuía elevado número de trabalhadores urbanos 
[...] Borghi seria uma constante ameaça ao controle de Getúlio sobre a seção paulista do PTB que já era fraca” (p.76).

Tanto no caso de Hugo Borghi como nas acusações mais amplas de desfavorecimento do PTB paulista por parte dos homens de Getúlio, o sentido das alegações é evidente: seria difícil manter o controle sobre a seção paulista do PTB, caso ela crescesse demais eleitoral e organizacionalmente. Afinal, haveria o imaginário de que candidatos fortes do PTB paulista constituiriam bases sociais poderosas através dos operários industriais. Além do fato de que a força de uma seção paulista significava surgimento de lideranças que trariam, por si mesmas, o patrimônio eleitoral do maior colégio de eleitores do país. E por óbvio, Vargas e as lideranças do PTB nacional não tinham interesse em ver seus domínios ameaçados, por quem quer que fosse. E especialmente, sabiam do perigo que poderiam representar líderes paulistas que conseguissem arregimentar o apoio de um estado tão populoso quanto São Paulo. A bem da verdade, o raciocínio poderia valer para qualquer partido político: trta-se da idéia de que a força da seção paulista paulistanizaria o partido. E estadualizar um partido em São Paulo, fazê-lo forte em São Paulo, traria o risco de desnacionalizá-lo. Vale a pena reproduzir um excelente trecho do livro de Maria Celina D'Araújo (1992:51) sobre essa percepção:

Reconhecido como a unidade mais importante da federação, a nível econômico e eleitoral, os temores sobre a influência política de São Paulo assumiam proporções gigantescas. Se, por um lado, qualquer plano político eleitoral que pretendesse ser bem-sucedido dependia de seu apoio, por outro, pairava o temor entre as lideranças nacionais de que uma iniciativa paulista congregando setores majoritários das correntes políticas desse estado pudesse transformar-se, de fato, numa imposição nacional, dada a dimensão do seu poder de interferência.

Paradoxalmente, a sobrevivência política de São Paulo frente aos outros estados e ao poder central dependia de que seu poder regional fosse minimizado e de que a unidade dos partidos lá existentes estivesse desagregada, pois suspeitava-se de que o partido cujo diretório regional mais 
importante estivesse em São Paulo necessariamente se converteria num partido paulista. Em suma, para ser nacional, um partido não poderia ter em São Paulo seu principal reduto; e aquele que fosse o mais forte nesse estado teria que submeter-se a um papel nacionalmente secundário.

Uma outra possibilidade real, frequentemente aventada sobre as causas da debilidade do trabalhismo varguista em São Paulo, é o fato de que esse espectro político ter-se-ia, junto do sindicalismo, fragmentado em diversas forças políticas. Acredito ser este o ponto em que caberia assinalar que o crescimento eleitoral do PSP sobre as massas urbanas de São Paulo também ajudou a prejudicar o PTB, com quem passou paulatinamente a disputar os trabalhadores (BENEVIDES, 1989; SAMPAIO, 1982). É verdade que o PSP não era e nem pretendia ser um partido trabalhista, "nem no nome, nem no estilo de atuação que lhe foi próprio" (CARDOSO, 1978:50). Mesmo assim, ao servir de instrumento para o que teria sido o populismo adhemarista, o PSP atuava na tentativa de arregimentar o apoio dos trabalhadores para a base de Adhemar, aproveitando-se que o PCB havia sido ilegalizado e que o PTB era fragilizado de cima para baixo e pelas disputas internas.

Mas ao mesmo tempo, como afirmei em minha breve discussão sobre o PSP, não acho que tenha constituído na principal concorrência ao PTB durante a democracia de 1945. Indícios nesse sentido são oferecidos por Ferreira $(1960,1964)$ e por Weffort (1965) quando demonstram que, se comparados os desempenhos do partido ademarista e os dos partidos ligados a Jânio Quadros, já nas eleições da década de 1950 o perfil mais urbano e operário seria apresentado mais pelos janistas e por PTN e PDC, do que pelo ademarismo e seu PSP. De todo modo, porém, é inegável que o PSP contribuiu para o prejuízo da consolidação do PTB em São Paulo, inclusive atraindo quadros dissidentes que viam no PSP uma possibilidade de se manter num campo de atuação ambíguo quanto ao varguismo, mas não distante dos trabalhadores por definição, como 
eram as outras legendas. Com a vantagem de ser um partido cada vez mais interessante do ponto de vista da força eleitoral no estado.

A despeito dessa discussão sobre a fragmentação do trabalhismo, do movimento sindical e dos grupos urbanos que poderia solidificar o PTB, é certo que a querela entre o varguismo e os paulistas serviu no mínimo para colocar a direção do partido contra sua seção estadual. E esse mínimo não era pouca coisa, já que o PTB de São Paulo chegou a sofrer diversas intervenções e dissoluções de sua direção nacional, tendo sido ainda forçado a forjar alianças no estado que interessavam aos projetos do PTB no país. Esse cenário é detalhadamente descrito pelo livro de Benevides (1989), do qual cito o seguinte trecho a guisa de sintetizar o processo:

a trajetória do PTB é marcada pelas constantes lutas internas que o levaram a
fragmentar-se em grupos e 'alas', sempre cambiantes. A intervenção da
direção nacional tornava-se rotina - as chamadas 'comissões de
reestruturação' substituíam diretórios que supostamente deveriam ser eleitos
(p.19).

Contudo, suspeito que haja outro elemento que se possa somar a essa conturbada relação entre a seção estadual e o PTB nacional. Em uma citação que fiz há pouco, Delgado comentava que "Borghi seria uma constante ameaça ao controle de Getúlio sobre a seção paulista do PTB que já era fraca" (1989:76). O grifo é meu e tem como objetivo chamar a atenção para esse aspecto pouco explorado pela literatura: o PTB paulista já era visto como enfraquecido mesmo no começo do período, em 1945 e 1947, apesar de que nessas datas sequer tenha dado tempo para Getúlio intervir no partido ou para o sindicalismo se fragmentar tanto quanto o faria.

Por um lado, do ponto de vista da força eleitoral do partido creio que essa imagem que se fazia à época - compartilhada também por analistas - constitua uma ilusão. Como vimos no segundo capítulo, do ponto de vista eleitoral o PTB paulista 
inicia a democracia de 1945 com um patamar de votos que fica até mesmo acima de sua média nacional e do esperado estatisticamente. Realmente, é apenas no decorrer do período que o PTB de São Paulo decai seu desempenho eleitoral. Curiosamente, na contramão da tendência que apresentava no resto do país (LAVAREDA, 1991; LIMA Jr., 1983; VASSELAI, 2009b). Nesse sentido, as intervenções no partido, seus rachas que faziam diferentes alas apoiarem diferentes candidatos e as defecções do período devem realmente ter contribuído não para que o eleitor mudasse suas preferências como parece sugerido na leitura de Benevides (1989) sob o julgamento da inautenticidade. Mas devem ter sim contribuído para a perda de votos do PTB à medida em que ia diminuindo o número de candidatos próprios apresentados e também à medida em que quadros de algum apelo eleitoral não eram oferecidos aos eleitores. Quer porque tivessem abandonado a legenda, quer porque fossem boicotados nela. De toda sorte que, ao longo dos anos, os nomes de maior força nas urnas foram-se cristalizando em outras agremiações. Afinal, como argumentam Lima Jr. et. al. (1987:173): “a orientação das preferências continuaria ao sabor das disputas partidárias, cujas condições vão além das simples transformações da estrutura sócio-econômica, envolvendo fatores tais como grau de organização dos partidos, imagem dos candidatos, carisma e radicalidade das disputa".

Mas por outro lado, no que se refere a entender especificamente a relação entre PTB e sindicatos independentemente de ela não ter levado a resultados eleitorais ruins ou abaixo da expectativa no início democrático, suspeito que seja interessante olhar para a situação já anteriormente à formação do partido. Refiro-me basicamente à questão: Getúlio tinha medo de que os movimentos sociais e operários pudessem escapar ao seu controle por não dependerem do varguismo e por isso criou uma estrutura trabalhista em que essas lideranças saíssem de dentro para fora da máquina pública, de cima para baixo 
na relação Estado-sociedade. Mas teria ele conseguido capturar movimentos constituídos antes disso? Antes da formação do PTB, antes da criação do Ministério do Trabalho e dos institutos e autarquias, antes da legislação sindical e trabalhista, antes do Estado Novo e até da Revolução de 1930?

Já nos anos 50, Hélio Jaguaribe (1953:147) diria que "ainda hoje, decorridos mais de vinte anos desde a Revolução de 30, a sindicalização, salvo no Estado de São Paulo e até certo ponto, no Distrito Federal, não é um movimento espontâneo do operariado, mas o produto de uma política governamental”. Pergunto-me, de passgem, se parte da dificuldade inicial do PTB em trazer para suas hostes os movimentos de trabalhadores paulistas não residiria no fato de que em São Paulo havia porcentagem muito maior de sindicatos e movimentos de trabalhadores que não eram vinculados, ao menos não no nascimento, ao varguismo. Além disso, preocupado em entender porque o operariado paulista fazia cada vez menos greves ao longo da democracia de 1945, enquanto os de outros estados aumentavam fortemente sua movimentação de tipo grevista, Leôncio Martins Rodrigues (1989:545) argumenta:

É possível que as motivações de participação em greves e movimentos de cunho nitidamente político não fossem suficientemente fortes para levar os trabalhadores [de São Paulo] a enfrentarem as represálias das empresas privadas [...] É possível, igualmente, que o projeto nacionalista-reformista não chegasse a sensibilizar mais fortemente os trabalhadores do setor moderno da economia.

O intuito dessa breve menção não é, nem de longe, re-encampar aquela idéia vaga e um tanto provinciana sobre a singularidade paulista. Como se a existência de um operariado pouco capturado pelo varguismo indicasse um maior liberalismo, uma maior tradição democrática, um desenvolvimento social ou político de estágio mais avançado. Aliás, nem mesmo seria possível, pois afinal é preciso recordar que, se esse sindicalismo não se alinhou ao PTB ou ao varguismo, do ponto de vista eleitoral acabou 
muitas vezes no apoio do PSP, PTN ou PST. E não creio que a base de apoio de Jânio Quadros constitua o que os defensores da singularidade paulista chamariam de partidos trabalhistas ideais. Não creio que estivessem tão distantes assim dos vícios usualmente computados ao varguismo. Com essa discussão quero, na verdade, sugerir que parte dos sindicatos não esteve com Vargas por uma questão de anterioridade, não de maiores brios ideológicos. Nascidos fora do varguismo, aproximaram-se antes do comunismo, do socialismo, do anarquismo. Depois de extinto o PCB, esses grupos distribuíram-se partidariamente, mas muitos se mantiveram sob a esfera comunista no âmbito sindical (BRANDÃO, 1997; FRENCH, 1988). Parte do operariado paulista não era varguista não por ter índole liberal diferenciada, mas porque não nasceu da política de Vargas e sim cronologicamente antes dela (pode ser que também aqui, o timing importe).

Mais do que defender a igualdade valorativa do resto do Brasil, pretendo com esse argumento relembrar aspectos interessantes da relação entre o varguismo e a política paulista em geral. No que se refere a quase todos os partidos políticos, o eleitorado paulista tinha poucas opções de voto que fossem próximas a Vargas ou que enunciassem algo análogo ao varguismo. E curiosamente, até mesmo parte importante dos trabalhadores e dos movimentos sindicais oferecia ao eleitorado de São Paulo uma outra vertente, um outro tipo, de não-varguismo. Vez ou outra até de anti-varguismo, dentro da crítica ao peleguismo sindical dos grupos próximos a Getúlio. Sindicatos e trabalhadores independentes do varguismo, quer fossem ou não ligados ao PSP, ao PTN, ao PST, ao PDC, formavam um contingente cuja oferta eleitoral tampouco era o varguismo. Para piorar, afetaram desde o início a consolidação do PTB no estado: antes de surgirem outras legendas afetavam pelo simples fato de que não iam cerrar posições junto aos petebistas. Depois, afetavam porque iam tomar assentos em partidos concorrentes diretos. 
E se não bastasse, o próprio PTB paulista acabou por oferecer poucas opções propriamente varguistas. Não sem razão a definição caricatural de Hélio Jaguaribe (1962:9), para quem “a UDN do Sr. Magalhães Pinto [de MG] está à esquerda do PTB da Sra. Ivete Vargas [de SP]". O PTB acabou rachado em diversas frentes internas durante todos os pleitos. A intervenção de Getúlio com temor de São Paulo foi um fator claro de desorientação partidária. Mas não só: em geral as diversas alas paulistas do PTB apoiavam candidatos alheios ou opostos a Vargas. Benevides (1989) conta que o PTB de São Paulo jamais apoiou um candidato único para qualquer cargo majoritário em questão. E muitas vezes apoiou, na verdade, todos os candidatos em disputa através de suas múltiplas divergências internas.

Além disso, mesmo depois de sofrer o ditame da direção nacional, nada garantia o real apoio às propostas, às decisões e aos candidatos forçados pelos homens de Getúlio. Por certo, as decisões que vinham de cima eram estabelecidas, mas não contavam com nenhuma base sólida interna na seção paulista. O PTB paulista foi mais fraco do que no resto do país porque não pôde, ou não quis ou não conseguiu monopolizar as lideranças e os apoios trabalhistas e sindicais disponíveis. E porque não pôde, ou não conseguiu ou não quis oferecer o mesmo que oferecia em termos eleitorais nos outros estados. E de um modo ou de outro, em geral o trabalhismo paulista não varguista oferecia mais esse leque de opções distantes do varguismo: um PTB alterado, um sindicalismo independente de Vargas e um grupo sindical-trabalhista em partidos alheios a Vargas.

\section{Jânio Quadros}

Essa exposição que venho fazendo sobre a formação e às vezes sobre o desenvolvimento das legendas partidárias em São Paulo pode acabar deixando uma 
impressão errônea. Se os grandes partidos nacionais não conseguiam estabelecer bases firmes e bem estruturadas no estado, isso não quer dizer que outras lideranças de peso e grupos políticos relevantes não surgissem em âmbito estadual. Ou seja, a não penetração dos partidos nacionais em São Paulo é um lado da moeda. Mas não garantiria automaticamente a não nacionalização de políticos paulistas. Como se configurava esse outro lado da moeda?

É claro que a fraqueza do PTB, do PSD e da UDN, e a ilegalização do PCB, fragilizavam as principais pontes políticas pelas quais algum político profissional paulista pretendesse ascender aos negócios nacionais ou mesmo influenciar os rumos quer da nação, quer dos partidos que disputavam o governo da nação. O problema é que, via de regra e sistematicamente, para ter força na arena nacional, sempre seria melhor contar com o respaldo de partidos nacionalmente consolidados. Como se sabe, a negociação via partidos é incomparavelmente mais forte do que a barganha individual. E os recursos eleitorais, a despeito daqueles que imaginam a eleição em lista aberta como o pesadelo personalista, são incomparavelmente mais densos quando o candidato apóia-se em uma estrutura partidária. Afinal de contas, simplesmente para ganhar eleições nacionais, era muito mais fácil a um político estadual estar filiado às três grandes legendas do que a partidos menores.

No que se refere às lideranças políticas individualmente, o curioso é que, em qualquer dos partidos de São Paulo - incluindo as seções do PSD e parte do PTB, mas principalmente no forte PSP e nos ascendentes menores (PTN, PDC) - as opções de lideranças políticas nacionalizáveis ofereciam, ao menos no nível estadual, um alinhamento diverso daquele que a nação parecia demandar majoritariamente. Com exceção da aliança entre Ademar e Vargas em 1950, as grandes lideranças de São Paulo eram não alinhados ao projeto varguista, inclusive seu concorrente. Frequentemente, 
eram mesmo anti-varguistas. Dito de modo mais simples, é fácil reparar que os grupos políticos que ganharam o governo de São Paulo; ou que eram mais fortes em relação ao esperado na Assembléia Legislativa; e às vezes até mesmo na bancada federal paulista, eram grupos que não estavam próximos de Vargas. E em geral, portanto, quando tentavam ascender ao nível nacional por qualquer via política formal, concorriam com esse pólo dominante no que se refere a toda sorte de recursos - eleitorais ou de poder e disputavam portanto sempre fora do que foi sempre o campo majoritário da política nacional.

Faço sempre questão de ressalvar: não significa que nenhum paulista conseguisse chegar a ser uma liderança importante na política do país. Tenho ciência de que alguns nomes podem ser citados à título de contra-argumento. Mas nomes nada dizem sobre a regra. São exceções. Quando afirmo que as pontes de ligação entre a política paulista formal e a nacional estavam prejudicadas pela debilidade das agremiações nacionais no estado, e pela dificuldade de composição entre os grupos políticos surgidos em São Paulo e o varguismo, quero dizer que se prejudicava a inserção sistemática, via de regra. Ou seja, quero dizer que se dificultava, não que se impossibilitava.

Sem dúvida alguma, o nome mais proeminente a ser citado entre essas exceções foi Jânio Quadros. A seção à parte que dedico a ele não se deve computar no suposto de que tenha sido Jânio uma figura política mais importante ou mais intrigante do que Ademar de Barros, por exemplo. Dedico algumas palavras a Jânio, em separado, e logo na seqüência de minha análise sobre os partidos políticos da democracia de 1945, por causa de um fato que é de interesse por si só: o ex-prefeito paulistano, ex-governador paulista e ex-presidente do país foi sempre, declaradamente, um homem sem partido político (BANDEIRA, 1979; CHAIA, 1992). Ou melhor, filiado a partidos tal como 
exigia a lei, mas acima dos partidos. Não seria possível, pois, enquadrá-lo na discussão detida de nenhuma legenda do período de 1945, tal como no que se refere a Ademar de Barros.

Hélio Silva (1983) comenta, com razão, que Jânio não possuía nenhum dos atributos que ajudariam ou dariam base a uma carreira forte: não possuía dinheiro, nem era dono de um jornal, sequer havia montado seu próprio partido. Possuía poucos contatos, homem de pouca expressão política que era. Vera Chaia (1992) conta que, sintomaticamente, o começo da carreira de Quadros dera-se com a filiação à UDN paulista. Da qual se retirou em busca de uma agremiação mais popular, uma vez que "a UDN seria sofisticada demais" (p.18). Encontrou a guarida que procurava, não por acaso, no PDC: partido que tentava afigurar-se como moderno e de massas, mas não à esquerda (ibidem:19). Sua candidatura à primeira eleição de prefeito da capital era sem recursos e pequena, casando bem com a imagem que Jânio pretendia para si e que conseguiu cunhar através de seu famoso slogan do "tostão contra o milhão". Quadros venceu o pleito e tornou-se prefeito.

No ínterim do mandato, abandonou o cargo para candidatar-se ao governo estadual - no que aliás angariou a crítica da imprensa e de setores que o apoiavam . Candidatou-se, dessa feita, pelo PTN criado por Hugo Borghi, pois seu pouco caso com o PDC fizera-o atritar com a direção paulista da legenda de modo irreversível. Venceu a eleição estadual. Depois de governador, tentou a presidência agora pela UDN, através das mãos de Carlos Lacerda, e foi outra vez vitorioso, em uma carreira meteórica e sem paralelo na história do país. Segundo Chaia (1992), Lacerda enxergava em Jânio Quadros a única possibilidade de a oposição chegar ao poder e destronar os herdeiros de Getúlio. De fato, como se sabe, durante os poucos meses que seu governo durou antes da renúncia à presidência, Jânio teve de governar sem nenhum apoio por parte dos 
partidos ou dos grupos políticos alinhados ao varguismo. Mas ainda que tenha executado, durante sua rápida passagem pela presidência, o governo mais liberal do ponto de vista econômico pelo menos desde 1930, para alguns autores não está clara a relação do projeto político de Jânio para com o varguismo. Benevides, por exemplo, afirma que "Jânio Quadros manterá, sempre, sua ambigüidade em relação a Getúlio" (1989:33).

Mas é verdade que Quadros esteve, durante praticamente toda sua carreira, alinhado aos grupos paulistas mais contrários a Vargas, como era o caso de UDN e PDC, e ao agrupamento do PTN que era fruto, em si mesmo, das desavenças entre aquela parcela do trabalhismo e a interferência dos homens de Getúlio sobre o PTB. O caráter oposicionista de Jânio também ficara claro na campanha ardorosamente crítica ao desenvolvimentismo de Kubitschek (BANDEIRA, 1979; CHAIA, 1992) - que, nos termos em que argumentei, simbolizava em boa medida a continuidade do varguismo. Mas mais importante do que tais fatos, creio que seja central entender o conjunto de conceitos complexos que estava por trás do outro famoso emblema de Quadros: a vassoura. Não apenas na candidatura presidencial, mas principalmente nela, a vassoura que varreria a corrupção virou um projeto político de marca maior, dando uma conotação mais propriamente política ao moralismo que Jânio já manifestara também em suas vias puramente tradicionalistas - como no famoso caso da proibição do uso dos biquínis (SILVA, 1983).

A importância do moralismo como bandeira de Jânio perpassa até mesmo sua figura. O discurso de purificação da política era, como vimos, típico de todo o histórico da UDN: a denúncia à corrupção administrativa (BENEVIDES, 1981:267). Mais do que isso, arrisco dizer que em certo sentido era uma herança de pensamento político muito anterior. Não é à toa que Lacerda houvesse identificado o moralismo udenista como 
“uma projeção no tempo do que fora o tenentismo das antigas revoluções" (1978:153). A correção da política já estava presente na substituição da política pela técnica em prol da técnica, propalada pelo anti-liberalismo que Campello (1976) identifica no Estado Novo. Era parte integrante dos autoritarismos instrumentais descritos por Wanderley Guilherme dos Santos (1978). Foi parte integrante do nexo político da UDN. E também de Jânio, que defendia a moralização, a perseguição aos criminosos dos cargos públicos. Defendia a devassa nos governos antecessores: para Francisco Weffort (1965), Jânio “assinalou seus governos em São Paulo por uma política dura e impessoal, perseguiu funcionários, agitou problemas políticos”. Propugnava a negação dos partidos e a superioridade da técnica sobre a política.

Para Benevides (1981:267), “o moralismo também recorreria à visão de fundo autoritário, no sentido de identificar, nos valores morais dos homens públicos, a ‘explicação' para o comportamento político". Entre outras feições, "no moralismo udenista, distinguiam-se, portanto, os seguintes aspectos: o moralismo individualista, com ênfase na probidade pessoal; o combate à corrupção administrativa, como tema de atuação parlamentar, e o elitismo, na idéia de que 'o poder corrompe"'. Em relação a Jânio Quadros, Oliveiros Ferreira (1964:179) comenta que o ímpeto do movimento janista, nesse sentido, era o de que "as palavras de ordem [...] eram aceitas pelo eleitorado juntamente com as de colocar a máquina estatal a serviço da coletividade e não mais de interesses pessoais ou de grupos". Nesse sentido, são centrais as comparações de Weffort (1965) entre os papéis políticos desempenhados por Ademar e por Jânio: “o ademarista típico, da fase 'progressista' ou da fase conservadora, imagina um Estado protetor, assistencial, ao qual se possa recorrer em caso de dificuldade sem os impedimentos técnicos de uma administração racional e impessoal” (p.58). Enquanto, por outro lado, “o moralismo das massas janistas toma o conteúdo muito 
popular de limitação dos privilégios que se associam à corrupção; elas já não podem partilhar a esperança de favores pois o que efetivamente conta, nas condições de sua integração à vida urbano-industrial, é sua capacidade de trabalho” (p.59).

Mas o que é especialmente interessante é notar que não fora apenas Jânio ou a enfraquecida UDN que adotaram o discurso da impessoalidade política. Kugelmas (1985) e Ferreira (1964) apontam que os governadores Nogueira Garcez, sucessor de Ademar, e Carvalho Pinto, sucessor de Jânio, possuíam a inclinação à valorização da técnica sobre a política. Como se sabe, efetivamente ambos foram secretários de governo de seus antecessores e haviam se notabilizado pela gestão técnica dos negócios do estado. Ambos personificavam a idéia do bom gestor. As semelhanças são intrigantes: segundo Kugelmas, "os dois se desligaram de seus patronos, os dois projetavam uma imagem pouco 'partidária' no período pré-64 e os dois foram figuras exponenciais do 'establishment' paulista" (1985:34).

Nas palavras de Ferreira (1964:182), efetivamente “em 1958 o professor Carvalho Pinto [foi] eleito sob o lema de 'mais administração e menos política'. Ao mesmo tempo, sabe-se também que a própria candidatura vitoriosa de Ademar em 1962 mudou de discurso e paradigma e passou a defender menos politização, mais trabalho. Segundo Weffort (1965:56), “nas eleições de 1962 a propaganda ademarista mudou sua orientação tradicional. Já não apresenta o líder apenas como o homem 'progressista' e 'realizador', mas acentua a imagem do patriarca com a chamada 'política do amor' que promete 'paz' e 'tranqüilidade'”. Sobre esse pleito, aliás, Ferreira (1964:197) sugere que a disputa à vice-governança do estado teria sido marcada por "extremo a-politismo", como por exemplo a "campanha do Sr. Laudo Natel, que a certa altura de sua propaganda encarecia o fato de não ser "político"”. 
A tônica da purificação da política e de sua substituição tanto quanto possível pela técnica orientou boa parte das lideranças paulistas. É certo que talvez isso possa ter ocorrido exatamente porque, encerrados em uma disputa partidária no estado que pouco tinha a ver com a que se dava no nível nacional, alguns paulistas tendessem à se afastar da "política que se fazia" como se ela fosse toda a "política". Algo como um dar de costas à política nacional tal como se mostrava, uma vez que os políticos de partidos como PSP, PDC e PTN tinham pouco espaço para transitar na esfera nacional. Talvez isso ajude a explicar, mas é apenas conjectura. $\mathrm{O}$ fato é que, por um ou outro motivo, a política paulista oferecia varguismo de menos, quando comparada às disputas do resto do país, e moralismo a mais ${ }^{39}$.

Vale lembrar: se considerarmos muito genericamente que o varguismo simbolizou a formação mais clara do pólo político e econômico que Bolívar Lamounier (1977) identificou como "ideologia de Estado", os anti-varguistas não chegaram a constituir os representantes exatamente do outro pólo, a "ideologia de mercado". Pelo contrário, como se sabe e como é consistentemente exposto por Benevides (1981) e por Dulci (1986), a UDN - que era a guarida principal dos opositores do varguismo diversas vezes afastou-se de preceitos básicos da defesa da "ideologia de mercado". Quer do ponto de vista econômico, quer do ponto de vista político através da defesa do golpismo, do elitismo, do voluntarismo, entre outras características. Suspeito que a interpretação mais precisa do que simbolizaram os anti-varguistas nesse contexto temático teria sido algo próximo ao que se poderia chamar de "ideologia do moralismo". No famoso texto "O moralismo e a alienação das classes médias", os

\footnotetext{
${ }^{39}$ Não se pode dizer que os partidos de grande influência paulista da democracia de hoje, PSDB e PT, enquadrem-se nessa descrição. No entanto, essa análise permite ao menos pensar em um aspecto interessante: ambos foram os partidos que, enquato oposição, adotaram fortemente o conceito de moralização da máquina pública. Ainda que através de matizes diferentes: o PT defendia a substituição dos homens sem caráter, enquanto o PSDB concentrou-se no estilo gerencial em oposição ao que seria o entesouramento da máquina pública.
} 
Cadernos do Nosso Tempo (1954) afirmavam, com razão, que "as campanhas de moralização que ora se processam [...] são movimentos que adquirem uma intensidade e uma extensão de grandes proporção, ao ponto de se constituírem na forma mais importante e ativa de oposição ao governo".

Infelizmente, desenrolar essa sugestão sobre a existência de uma "ideologia de mercado" em nível mais aprofundado fugiria sobremaneira ao escopo deste trabalho. Mas por certo, cabe adiantar que o moralismo está próximo do liberalismo da "ideologia de mercado", ao mesmo tempo em que se afasta. Talvez o flerte entre essas duas "ideologias", para continuar usando o termo de Lamounier, ganhe alguma diferenciação se partirmos de duas premissas. Primeiro, a idéia de que o moralismo coloca a transformação ética e a transformação do fazer político como fins em si mesmos, não como meios. E segundo, enquanto a "ideologia de mercado" seguiria o diagnóstico de Raymundo Faoro (1958) e buscaria desconstruir o peso que o Estado possui na determinação da sociedade, emancipando-a, o moralismo encontra-se na chave mais tradicional do pensamento político, segundo a qual se deve na verdade combater a captura que o privado faz do público.

Se há algum fundamento de verdade em apontar que vários nomes da política paulista adotaram o moralismo como plataforma política, em variados graus de intensidade, cumpre ressaltar que Jânio Quadros não se resumia a esse aspecto. Aqui entra sua briga do "tostão contra o milhão" e, mais especificamente, sua inclinação a buscar as massas. O moralismo janista tinha pés descalços, estava assentado numa projeção política popular. Colocava ao alcance do povo a idéia de que a reforma da política lhes constituía um ganho social concreto, não era apenas um preciosismo ético ou um arroubo retórico. Por ser uma UDN com cheiro de povo, Jânio podia causar a briga do tostão com a vassoura. É apenas por isso que, segundo Ferreira, 
A esse desejo profundo de uma reforma social no sentido definido de início [...] somou-se, de princípio inconscientemente, mas com nítida consciência em 1958, o anseio de colocar a máquina do Estado a serviço da nova realidade social que vinha surgindo dsede 1930, isto é, dar-lhes funções compatíveis com a estrutura urbana da sociedade, retirando-lhe o sentido de máquina política colocada a serviço de interesses facilmente personalizáveis (1964:182).

E continua, em trecho lapidar:
'a vassoura' preenchia as funções próprias da 'revolução do tostão contra o milhão', já que numa estrutura agrária fechada, em que o Estado é representado através de uma intermediação e como um sistema de prestação recíproca de favores e serviços, o rompimento prometido dessa estrutura de dominação passou a significar uma transformação política de amplo sentido reformista e de profundos reflexos nas relações de dominação e subordinação em termos sócio-economicos (p.183)

Jânio Quadros conseguiu revestir o moralismo de tipo "fim em si mesmo" com um verniz modificador de algo maior. Modificador, talvez, da política do favor, ou quem sabe atenuador da "autocracia burguesa" sob "democracia de cooptação" de que falava Florestan Fernandes (1987). Pouco importa se as intenções eram sinceras e, se eram, porque não se realizaram. O relevante é entender uma das facetas mais intrigantes que Jânio representou: conseguiu, a meu ver, dissociar a reforma da política da crítica ao legado varguista de tal modo que se colocou, no nível nacional, acima das clivagens políticas usuais em torno do varguismo. Não digo com isso que atenuasse sua vinculação oposicionista, sua vinculação aos mais duros anti-varguistas, como Carlos Lacerda. Sugiro apenas que o tom moralizante que deu a seu discurso foi mais geral do que o combate personificado a Vargas. E na verdade, servia em certo sentido como a idéia de que reformar a política era necessário, útil, desejável e inadiável, a despeito das preferências substantivas quanto a policies ou quanto a uma série de outros posicionamentos. 
A situação partidária em São Paulo, pois, era tão diversa que a figura mais nacionalizada que o estado produziu, a figura da política paulista com maior potencial eleitoral, foi exatamente aquela que assumidamente desprezava os partidos políticos. "Figura desterritorializada", para alguns (BARBOZA FILHO, 1995:118). Mas um político cujas pessoas próximas eram todas de seu círculo paulista e que só se sentia apoiado e fortalecido quando levava seu governo itinerante para despachar de São Paulo (CHAIA, 1992). A figura política mais expressiva de São Paulo era aquela que desprezava partidos e que acabara sendo o exemplo vivo do isolamento político de parte das forças do estado. A figura política paulista que melhor se nacionalizou foi a do único quadro que conseguiu fugir à clivagem do varguismo.

\section{Considerações finais}

Tenho sempre a preocupação de evitar a sugestão de que a situação dos políticos paulistas fosse homogênea ou imutável ou predestinada pela origem. Não era nada disso. É evidente que diferentes políticos de São Paulo tinham diferentes inserções e desempenhos nacionais - bem como diferentes relações com os líderes nacionais alinhados a Vargas. Também é certo que não estava dado, pela formação dos partidos em São Paulo, que seriam necessariamente fracos, e se o fossem, não necessariamente o seriam para sempre. A única sugestão que faço aqui é que a formação dos partidos em São Paulo e, mais importante, sua formação marcada pela relação entre os políticos profissionais paulistas e o varguismo, podem ter desempenhado um papel importante. Papel não determinístico, mas dificultador da relação entre a política paulista e a nacional. Não é que as escolhas dos políticos profissionais de São Paulo sob Estado Novo e na passagem para a democracia tenham necessariamente causado algum padrão ou singularidade da política paulista. Mas sim, sugiro que modificaram o leque de 
possibilidades de desenvolvimento das opções eleitorais da política paulista. Não causaram (caused) mas sim moldaram (shaped).

Do mesmo modo, seria insensato afirmar ou que não houvesse políticos varguistas em São Paulo, ou que o próprio eleitorado paulista tivesse um alinhamento diverso ao varguismo do restante do país - algo como se existira um verdadeiro ethos não varguista no mais rico estado do país. É certo que havia adeptos de Vargas, e posteriormente da linha política que Vargas deixou de herança. Lderanças fiéis, políticos próximos ao círculo nacional de líderes, nomes paulistas que queriam construir em São Paulo o mesmo domínio eleitoral que pareciam estar conseguindo alhures. O verdadeiro ponto a se observar é que essas lideranças eram raras, exceções, e pessoais, ou seja não refletiam a existência de grupos ou de padrões. Mais importante ainda: por causa disso, tinha caminho de acesso à política nacional não impossibilitado, mas sempre dificultado. Por outro lado, quanto ao eleitorado paulista, qualquer afirmação é puro determinismo: por que haveria o povo de São Paulo de votar diferentemente do restante do Brasil? Não há nenhum indício de que o fizessem, mas sim de que as opções a que eram apresentados para votar em geral eram singulares. Volto a lembrar Schumpeter: a democracia não é a escolha das opções preferidas, mas a escolha entre as mais preferidas dentre as opções dadas. E o meu grande objetivo neste ponto foi argumentar que a tal particularidade, de que a política paulista entre 1945-64 é sempre acusada, parece estar antes em como foi se formando o leque dessas ofertas políticas aos eleitores. 


\section{Conclusão}

Parece que, hoje em dia, a grande presença de políticos de São Paulo na política nacional, nos noticiários, nos grandes partidos, vem sendo vista com alguma naturalidade. Afinal, como se diz, o estado de São Paulo seria a locomotiva econômica do país. E paulistas são, ademais, o maior eleitorado do Brasil. É surpreendente a proximidade entre esse senso comum e os pressupostos que estavam por trás do espanto com que a literatura e os analistas enxergavam o ocaso da inserção dos políticos paulistas na democracia de 1945-64. A naturalidade com que hoje não se perguntam o porquê de tantos paulistas dominarem as atenções da política nacional recente denuncia, em larga medida, o que se esperava ter acontecido entre 1945-64.

A dúvida sobre por que os políticos de São Paulo pareciam estar tão menos presentes na democracia de 1945 do que durante a República Velha ou durante os dias atuais foi geralmente assentada sobre duas ordens de julgamentos. Por um lado, supõese geralmente que a influência política dos paulistas deveria ser correspondente ao poderio econômico do estado - ainda que nunca se defina em que patamar de poder político essa regra seria considerada como satisfeita. Por outro lado, supõe-se uma singularidade paulista de cunho valorativo em que a história política bandeirante é pintada com as tintas mais nobres da paleta liberal, democrática, progressista. Nas palavras de Campello de Souza (1977:78), trata-se da recorrente percepção de que "São Paulo, sobretudo a partir do surto cafeeiro, vem sendo o berço de movimentos libertários, autonomistas, contestadores, enfim de todo um padrão político em desacordo com o estilo autoritário, clientelista e burocrático prevalecente no resto do país”. 
Neste trabalho, não parti da tentativa de responder "por que os paulistas não foram o que deveriam ter sido". Creio que a pergunta correta seja: quais as diferenças de cenário que levam a diferentes resultados? Especificando: quais desenvolvimentos históricos e políticos levaram a um resultado diferente do que se via antes de 1930 e diferente do que se vê hoje? A resposta que ofereci inspira-se, em sua tônica mais ampla, na explicação de Kugelmas (1985) para a proclamação da República no Brasil. Sugiro que, enquanto os paulistas foram artífices da República e se destacaram na liderança da redemocratização da década de 80, algo bem diferente aconteceu no surgimento da democracia de 1945. Primeiro, a Revolução de 1930 foi deflagrada à revelia da política paulista em geral, ainda que alguns grupos fossem mais ou menos avessos a ela do que outros. E na passagem do Estado Novo para a democracia, os políticos do estado não apenas foram coadjuvantes do processo democratizador como, para acrescnetar, o período que nascia mal disfarçava a continuidade de diversos elementos do período que se encerrava.

Sendo menos genérico: as forças políticas de São Paulo eram as derrotadas do Estado Novo. E essa relação com o varguismo acabaria marcando a formação dos partidos no estado. Acontece que o processo de formação das legendas foi central para definir os grandes players iniciais da democracia de 1945, tal como aponta Campello de Souza (1976). A combinação da relação entre políticos profissionais paulistas e o varguismo com a centralidade da formação partidária naquela democracia complicou a situação da maioria das lideranças políticas de São Paulo. Em linhas gerais, o estado foi o único no qual não surgia um partido varguista a partir da máquina burocrática do Estado Novo. E apenas ali, pelo contrário, uma força política não-varguista utilizava-se dessa prerrogativa. Desenvolvi um esforço analítico no sentido de argumentar que as relações entre os diversos matizes políticos de São Paulo e o varguismo foram 
determinantes para formar e desdobrar a história dos partidos políticos e das forças políticas do estado na democracia de 1945. Boa parte dos políticos de São Paulo teve dificuldades de compor com o varguismo de modo tão estável e tão profícuo quanto eram estáveis as alianças que se fazia nos outros lados do país. E ao mesmo tempo, a situação política no estado foi-se configurando de tal modo que os partidos políticos praticamente não se alinhavam a Vargas no mesmo patamar de freqüência, lealdade e intensidade apresentado por seus pares do restante do Brasil. Em São Paulo, os partidos políticos nacionais eram mais fracos. Mas além disso, em São Paulo saltava aos olhos a existência de varguismo de menos, se comparamos com outros estados e com a esfera nacional, e não-varguismos ou anti-varguismos a mais. Especialmente, moralismos a mais.

$\mathrm{O}$ argumento geral que desenvolvi foi a idéia de que os paulistas que aceitaram participar do governo ditatorial de Vargas acabaram formando partidos a partir da máquina com um padrão diferente do que se deu nas outras seções estaduais das legendas. Apenas em São Paulo, um partido não-varguista foi construído com a força do uso do aparato de estado: o PSP. E até mesmo o PSD usualmente getulista acabou tendo seus quadros migrando para o PSP atrás de recursos de poder ou de liberdade de atuação independe em relação ao varguismo. Mesmo assim, enquanto seria de se esperar que os pessedistas remanescentes fossem então aqueles varguistas mais sólidos, surpreendentemente o partido aproxima-se é da UDN do estado. Essa, por sua vez, sofreu também as conseqüências do fortalecimento do PSP. Mas não como o PSD, por não ter acessado a máquina estadonovista no nível que atingia Brasil adentro. No caso dos udenistas, sofriam a forte concorrência de um PSP que, não-varguista, acaba atraindo lideranças, organicidade e até votos que pertenciam ao campo do antivarguismo. A UDN encontrou saturado o seu espaço de atuação e a ela coube aglutinar 
apenas os mais radicais detratores do varguismo. Mais radicais ou mesmo mais ideológicos - no sentido restrito de menos suscetíveis ao pragmatismo.

Por fim, apontei que mesmo o trabalhismo do estado de São Paulo não se formara do mesmo modo que nos outros estados. O trabalhismo paulista nasce em campo onde já havia sindicatos e movimentos sociais independentes de Vargas. Para piorar, o partido trabalhista varguista enfrentara a dura concorrência do PCB, que aglutinava boa parte dessas forças não presas ao varguismo. E como se não bastasse, o PTB estaria sempre dividido: grande parcela da legenda não estava disposta a seguir à risca as orientações dos homens de Getúlio. Por conseqüência, o antigo temor do domínio paulista fazia com que esses membros da direção nacional interviessem com frequiência e desestabilizassem sobremaneira a seção estadual do partido. Outra opção no campo dos grupos sociais ligados ao mundo do trabalho, o PCB nascera como a única legenda com promissora inserção nacional e que era ao mesmo forte em São Paulo. Mas apenas dois anos depois da democratização, os comunistas assistiram a sua legenda sofrer a cassação de seus eleitos e a ilegalização de suas atividades.

Essa gama de partidos não foi de todo fraca ou completamente negligenciável em São Paulo. Mas seu desempenho ali era sempre abaixo de suas médias nacionais e do esperado do ponto de vista do desempenho no resto do país. Isso significava, em termo relativos, que uma parcela bastante grande dos cargos legislativos e a totalidade dos cargos executivos em disputa foram postos ocupados por representantes de legendas distantes do varguismo - cuja concorrência impedia que os udesnitas se beneficiassem da fraqueza dos varguistas no estado. Distantes não significa que não pudessem negociar, aliarem-se e tomarem parte dos governos nacionais via de regra indubitavelmente varguistas. Mas significa que tinham que passar por essa negociação e 
que, embora pudessem às vezes sentar à mesa, seriam não mais do que os convidados secundários do banquete.

O perigoso flanco a que exponho essa análise tem a ver com aquele pressuposto geral sobre o suposto ethos liberal paulista. É o risco da seguinte objeção: não faria a minha interpretação apenas referendar a singularidade paulista em relação à nação? Afinal de contas, se em São Paulo as forças próximas a Vargas eram mais esparsas, mais escassas e menos potentes, isso não é um sinal de que a política paulista conseguiu sucumbir muito menos à prática cooptativa, mantendo-se muito mais próxima da “ideologia de mercado" política de que fala Bolívar Lamounier (1977), e mais afastada de "ideologia de Estado"? Verdadeiramente, não creio que seja o caso. Se o varguismo tinha maiores dificuldades em São Paulo e se a política paulista foi pródiga em produzir lideranças estaduais afeitas ao discurso da negação da política, penso que não tenha a ver exatamente com o brio "liberal-democrático bandeirante". Frase entre aspas que, aliás, se levada ao pé da letra do conhecimento histórico conformaria uma contradição de termos.

Referindo-se à Contra-Revolução de 1932, Júlio de Mesquita Filho acusa, conformado e lamurioso, o distanciamento entre a proposta política que o Brasil almejava e aquela que boa parte de São Paulo, por seu suposto, pretendia:

We were certain that, once the splendid movement was victorious, we would see that for which all of the great ones of São Paulo had struggled, the Andradas, Feijó and Prudente, the great benefits of democracy, extend throughout all of Brazil. We were wrong when we assumed that the Andradas, Feijó, Prudente and Brazil were one and the same, when, in reality, [Brazil] was much closer to Getúlio Vargas and his kind (apud WOODARD, 2006:94).

Aquiesço fielmente à conclusão de que o Brasil estava mais perto do varguismo. E por decorrência lógica, se a política profissional de São Paulo estava distante do 
Brasil, é porque estava distante do varguismo. No entanto, não endosso o tom de desprezo com o qual Júlio de Mesquita Filho chega a essa conclusão, por julgar que o país deveria estar mais perto do padrão paulista. Esse tipo de suposição tem origem na idéia, mal disfarçada, de que o varguismo representava uma distorção da política moderna - representada a contento pelo que os paulistas tinham a oferecer. Aos analistas que se perfilam à opinião de tão nobre figura paulista como Mesquita Filho pelo jeito grande propalador das grandezas democráticas de São Paulo - proponho invertermos a lógica. A singularidade paulista não foi sua tendência socialmente atávica à modernidade política, mas antes sua rejeição maior à figura de Getúlio Vargas, à chamada era Vargas, ou ao que se queira entender por varguismo.

Julgo que se deva abandonar certo provincianismo apriorista e trocá-lo por uma análise puramente histórica e política: parte importante das lideranças de São Paulo, que por suposto combate o peso do Estado, não o faz porque os paulistas sejam mais liberais. Combate o peso e a ideologia de Estado porque o Estado era Getúlio Vargas. Dito de outro modo: os políticos paulistas de 1930, do Estado Novo ou da democracia não se afastavam mais do varguismo que outros políticos brasileiros porque esse projeto de Vargas fosse a encarnação da "ideologia de Estado". Na verdade, combatiam a “ideologia de Estado” porque ela era a encarnação do varguismo.

A maioria dos políticos paulistas de maior expressão na democracia de 1945 está nesse diapasão. E apenas em São Paulo, onde grande parte das elites políticas em geral jamais chegou a ser varguista, uma tal linha de atuação poderia predominar. O esboço de liberalismo político paulista surge como defesa contra um Getúlio Vargas que simbolizava, do ponto de vista político, a subjugação de São Paulo. Tanto que, antes de 1930, dificilmente a paulistocêntrica política do café-com-leite poderia ser classificada como politicamente liberal ou liberal-democrática. É verdade que a origens desse mito 
são mais antigas. Remontam à identificação fugidia entre federalismo e liberdade política, uma vez que os paulistas foram os construtores da federação desde as mais tenras reivindicações federativas no fim do Império, como apontam Kugelmas (1985) e Love (1982), entre outros. Mas é preciso ter claro: os paulistas - políticos, elites, como se queira - reclamavam muito mais o federalismo do que o liberalismo. E é desnecessário dizer: nem sempre ambos andam juntos.

Compreendo a polêmica do que estou afirmando: os paulistas não eram mais liberais e por isso eram mais refratários a Vargas. Eles eram antes refratários a Vargas e por isso mais liberais. Não se trata em absoluto de uma tendência à representação contra a cooptação, tal como na clássica colocação de Schwartzman (1975). Como se sabe - e a história mostra - a ligação automática entre industrialização, desenvolvimento e maior apoio às liberdades políticas só existe em nossas canetas e em nossas teclas. Fora do papel, há uma miríade de possibilidades e probabilidades que se abre. Possibilidades mediadas pelas relações políticas e pela história. E no caso, a relação com Vargas, ou melhor, a reação a Vargas, fez história.

Por fim, cabe ressaltar que neste trabalho propus uma interpretação política orientada pelas clivagens que existiram em torno do varguismo não para substituir ou combater análises ou defesas de outras clivagens, sejam sociológicas ou economicistas. Julgo apenas que seja necessário um outro tipo de abordagem centrada nas clivagens propriamente políticas, relacionadas aos alinhamentos, às alianças, aos posicionamentos, aos significados políticos. No caso, trata-se da necessidade de retirar os conceitos de varguismo e de anti-varguismo do mundo da determinação pela estrutura sócio-econômica singular de São Paulo. É preciso colocar o varguismo fora da escala evolutiva que termina na "ideologia de mercado". Fazendo isso, retira-se o peso do pré-julgamento e se colocam os termos como opções políticas e opções de políticas. 
Tanto o varguismo quanto sua antítese passam, assim, a ser ambos legítimos e louváveis - sem representar nenhum telos político. Pois passam a ser opções. Afinal de contas, se o pacote genérico do varguismo pode incluir, dependendo do que se lhe defina, maus elementos distintivos como o peleguismo sindical, também os antivarguismos possuem vestígios ruins como o elitismo imiscuído em parte de seu discurso moralista. Nenhum é bom ou ruim em si mesmo. Julgar que o problema do país é excesso de Estado sobre a sociedade ou que é, pelo contrário, ausência de Estado porque esse é capturado por parcelas muito diminutas da sociedade, são ambas opções plausíveis e legítimas. Pode ser desagradável, para alguns, fugir dessa armadilha provinciana e conseguir realmente equiparar varguismo e seu oposto como opções em pé de igualdade. Afinal, significa abrir a possibilidade de que se proponha, tanto quanto se falou em paulistanização do Brasil, também a brasilianização de São Paulo. 


\section{Bibliografia*}

ABRUCIO, Fernando Luiz. Os barões da federação: os governadores e a redemocratização brasileira. São Paulo: HUCITEC: Depto. de Ciência Política da USP, 1998.

ALMEIDA, Maria Hermínia T. de. Estado e classes trabalhadoras no Brasil: 19301945. Tese de Doutorado - FFLCH - Universidade de São Paulo, São Paulo, 1978.

"Federalismo, Democracia e Governo no Brasil: idéias, hipóteses e evidências". In: BIB - Revista Brasileira de Informação Bibliográfica em Ciências Sociais, n.51, $1^{\circ}$ sem., p.13-34, 2001.

AMARAL, Roberto (coordenador); SEGATTO, José Antônio et al. FHC: os paulistas no poder. Niterói, RJ: Casa Jorge Editorial, 1995.

AMES, Barry. "O Congresso e a política orçamentária no Brasil durante o período pluripartidário". Dados, Rio de Janeiro, v. 29, n. 2, 1986.

AMORIM NETO, Octavio, LIMA Jr. Olavo Brasil e SANTOS, Fabiano. "Fragmentação eleitoral e radicalização no Rio de Janeiro: impacto da política estadual na política nacional (1945-1964)", In: Revista de Ciências Sociais, Rio de Janeiro, v. 30, n. 2, 1987.

ANHEMBI, Revista. São Paulo, v. 1, n.1, 1950.

ARRETCHE, Marta. A Centralização no Estado Federativo Brasileiro. Tese de Livre-Docência - Faculdade de Filosofia, Letras e Ciências Humanas, USP, São Paulo, 2007.

BANDEIRA, Moniz. A renúncia de Jânio Quadros e a crise pré-64. São Paulo: Editora Brasiliense, 1979.

BARBOZA FILHO, Rubem. "FHC: os paulistas no poder". In: AMARAL, Roberto (coord.); SEGATTO, José Antônio et al. FHC: os paulistas no poder. Niterói, RJ: Casa Jorge Ed, 1995.

BEIGUELMAN, Paula. "Contribuição à teoria da organização política brasileira". Tese de Livre Docência - FFLCH - Universidade de São Paulo, São Paulo, 1967.

BENEVIDES, Maria Victoria de M. A UDN e o udenismo - ambigüidades do liberalismo brasileiro. Rio de Janeiro: Paz e Terra, 1981.

\footnotetext{
* O trabalho segue as normas de: FUNARO, Vânia et al. (Coord.). Diretrizes para apresentação de dissertações e teses da USP: documento eletrônico e impresso Parte I (ABNT). São Paulo: Sistema Integrado de Bibliotecas da USP, 2009.
} 
PTB e o trabalhismo: partidário e sindicato em São Paulo. São Paulo:Brasiliense, 1989.

BENI, Mário. Adhemar. São Paulo: Grafikar, s/d.

BIELSCHOWSKY, Ricardo. Pensamento econômico brasileiro - o ciclo ideológico do desenvolvimentismo. Rio de Janeiro: Contraponto, 1988.

BORGES, Vavy P. Getúlio Vargas e a oligarquia paulista - história de uma esperança e de muitos desenganos através dos jornais da oligarquia: 1926-32. São Paulo: Ed.Brasiliense, 1979.

BOSCHI, Renato R. e DINIZ, Eli. Empresariado nacional e estado no Brasil. Rio de Janeiro : Forense-Universitária, 1978.

BRAGA, Sérgio S. Quem foi quem na assembléia constituinte de 1946. Brasília: Câmara dos Deputados, 1998.

As relações entre o Executivo e o Legislativo e a elaboração da política econômica na primeira experiência de democracia presidencialista pluripartidária brasileira (1946-64). Tese de Doutorado - IFCH - Unicamp, 2008.

BRANDÃO, Gildo M. “A ilegalidade mata: o Partido Comunista e o sistema partidário entre 1945 e 1964". Revista Brasileira de Ciências Sociais, n.33, ano 12, p. 23-34, Fevereiro de 1997.

BRESSER-PEREIRA, Luiz C. "Origens étnicas e sociais do empresário paulista". Revista de Administração de Empresas, v. 3 (11), p. 83-103, Junho de 1964.

CADERNOS DE NOSSO TEMPO. "O moralismo e a alienação das classes médias." In: Cadernos do Nosso Tempo,n.s, 1954, pp.150-59.

CAMARGO, Aspásia. "La Federación Sometida. Nacionalismo, Desarrolista e Inestabilidad Democrática". In: CARMAGNANI, Marcello (Coord.). Federalismos Latinoamericanos: México, Brasil y Argentina. México: Ed. Fundo de Cultura Econômica, 1993.

CÁNEPA, Mercedes Maria Loguercio. Partidos e Representação Política - a articulação política dos níveis estadual e nacional no Rio Grande do Sul (1945 1965). Porto Alegre: Editora da UFRGS, 2005.

CANO, Wilson. Raízes da concentração industrial em São Paulo. Rio de Janeiro: DIFEL, 1977.

Desequilíbrios regionais e concentração industrial no Brasil, 1930-1995. Campinas: UNICAMP/IE, 1998.

CARDOSO, Fernando Henrique. "Partidos e deputados em São Paulo: os partidos e a representação política". In: CARDOSO, Fernando Henrique; LAMOUNIER, Bolívar. Os partidos e as eleições no Brasil. Rio de Janeiro: Editora Paz e Terra, 1978. 
. "Os Partidos Políticos e a Participação Popular". In: FLEISCHER (org), Os

Partidos Políticos no Brasil. Brasília: Cadernos da UNB v. 2, 1981.

CARONE, Edgard, República Velha, A. Editora Bertrand Brasil: São Paulo, $1^{\text {a }}$ Edição, 1988.

A Evolução Industrial de São Paulo 1889-1930. Ed. Senac São Paulo: São Paulo, 2001.

CARVAlHO, José Murilo de. A Construção da Ordem. Rio de Janeiro: Campus, 1980.

CARVALHO, Orlando de. "Os partidos políticos em Minas Gerais" In: Revista Brasileira de Estudos Políticos, n.2, 1957, pp. 111-12.

CASTRO, Antônio Barros de. 7 Ensaios sobre a economia brasileira. São Paulo: Forense, v.2, 1971.

CHAIA, Vera. A liderança política de Jânio Quadros, 1947-1990. Ibitinga, SP : Humanidades, 1992.

CHHIBBER, Pradeep e KOLLMAN, Ken. The Formation of National Party Systems: Federalism and Party Competition in Canada, Great Britain, India, and the United States. Princeton: Princeton University Press, 2004.

CODATO, Adriano N. "Elites e instituições no Brasil: uma análise contextual do Estado Novo". Tese de Doutorado - Instituto de Filosofia e Ciências Humanas - IFCH, UNICAMP, São Paulo, 2008.

COHN, Amélia. Crise regional e planejamento: o processo de criação da SUDENE. São Paulo: Perspectiva, 1978.

COHEN, Marleine. JK. São Paulo:Editora Globo, 2006 (Série Personagens Que Marcaram Época).

COSTA, Vanda Ribeiro. A Armadilha do Leviatã: A Elite Industrial Paulista e o Corporativismo no Brasil, 1930-1945. Tese de Doutorado - Instituto Universitário de Pesquisas do Rio de Janeiro, Rio de Janeiro, 1992.

D’ARAÚJO, Maria Celina. O Segundo governo Vargas 1951-1954: democracia, partidos e crise política. São Paulo: Editora Ática, 1992.

DAHL, Robert. Democracy and its critics. New Haven: Yale University Press, 1989.

DEAN, Warren. A industrialização de São Paulo: 1880-1945. São Paulo: DIFEL; EDUSP, 1971.

DELGADO, Lucila A. N. PTB: Do Getulismo ao Reformismo. Tese de Doutorado Faculdade de Filosofia, Letras e Ciências Humanas, USP, São Paulo, 1989. 
DINIZ, Eli. Empresário, Estado e capitalismo no Brasil: 1930-45. Rio Janeiro: Paz e Terra, 1978.

. "O Estado Novo: estrutura de poder, relações de classe" In: FAUSTO, Boris

(org). História Geral da Civilização Brasileira, v.3, tomo 3, 1989, p.77-120.

DULCI, Otávio Soares. A UDN e o Anti-Popuilismo no Brasil. 1. ed, Belo Horizonte: UFMG/PROED, 1986.

FAORO, Raymundo. Os Donos do Poder: Formação do Patronato Político Brasileiro. Rio de Janeiro/Porto Alegre/São Paulo, Editora Globo, 1958.

FAUSTO, Boris. A Revolução de 1930: historiografia e história. São Paulo: Brasiliense, 1986.

FERNANDES, Florestan. A Revolução Burguesa no Brasil: Ensaio de Interpretação Sociológica. Rio de Janeiro, Guanabara: Editora Globo, 1987.

FERREIRA, Oliveiros Silva. "Comportamento eleitoral em São Paulo". In: Revista Brasileira de Estudos Políticos, n. 8, 1960.

. "A crise do poder no sistema e as eleições paulistas de 1962". In: Revista Brasileira de Estudos Políticos, n. 16, 1964.

FIGUEIREDO, Argelina. Democracia Ou Reformas ? Alternativas Democráticas À Crise Política. Rio de Janeiro: Paz e Terra, 1993.

FONSECA, Pedro C. D. "Sobre a Intencionalidade da Política Industrializante do Brasil na Década de 1930" In: Revista de Economia Política, v. 23, n.1(89), Janeiro/Março de 2003.

FREIRE, Gilberto. "São Paulo e a unidade brasileira", In: MARCONDES, J. e PIMENTEL, O., São Paulo, espírito, povo, instituições. São Paulo: Ed. Livraria Pioneira, 1968.

FRENCH, John D. "Workers and the rise of Adhemarista populism in São Paulo, Brazil 1945-7” In: The Hispanic American Historical Review, v.68,n.1, 1988, pp1-43.

FUNARO, Vânia M. B. de Oliveira (Coord.) et al. Diretrizes para apresentação de dissertações e teses da USP: documento eletrônico e impresso. São Paulo: Sibi USP, 2004.

FUNDAÇÃO GETULIO VARGAS (Brj). Dicionário histórico-biográfico brasileiro: 1930-1983. Rio de Janeiro: Centro de Pesquisa e Documentação da Histórica Contemporânea do Brasil, 1984.

FURTADO, Celso. "Obstáculos políticos ao crescimento econômico no Brasil” In: Revista Civilização Brasileira, Rio de Janeiro, n. 1, 1965, p.75-89. 
Formação Econômica do Brasil. São Paulo: Companhia das Letras, 2007.

GALLAGHER, Michael. "Proportionality, Disproportionality and Electoral Systems".In: Electoral Studies, n.10, 1991.

GAUTHIER, Howard L. e SEMPLE, Robert K. "Tendências nas Desigualdades Regionais da Economia Brasileira 1947-1966” In: Revista Dados , n. 9, 1972.

GRAMSCI, Antonio. A Questão Meridional. Rio de Janeiro: Editora Paz e Terra, 1987.

HOLANDA, Sérgio Buarque de. Raízes do Brasil. 7.ed. Rio de Janeiro: J. Olympio, 1973.

HIPPÓLITO, Lúcia. De Raposas e Reformistas: o PSD e a experiência democrática brasileira: 1945-64. Rio de Janeiro: Editora Paz e Terra, 1985.

IBGE, Estatísticas do Século XX, Rio de Janeiro:IBGE, 2006.

JAGUARIBE, Hélio. “O que é o adhemarismo?" In: Cadernos do Nosso Tempo. IBESP, 1953.

. “As eleições de 1962” In: Tempo Brasileiro. Rio de Janeiro, v.1, n.2, 1962.

KINZO, Maria D. G. "São Paulo e o Brasil - uma desigualdade política”. In: São Paulo em Perspectiva. São Paulo, v.4, n.1, Jan/Mar de 1990, p.37-41.

KUGELMAS, Eduardo. "Políticas públicas na Administração paulista: 1946/77” In: Cadernos Fundap, São Paulo, ano 5, n.9, Maio de 1985, p.30-45.

Difícil hegemonia: um estudo sobre São Paulo na primeira republica. Tese de Doutorado - Faculdade de Filosofia, Letras e Ciências Humanas, USP, São Paulo, 1986.

LACERDA, Carlos. Depoimentos. São Paulo: Nova Fronteira, 1978.

LAMOUNIER, Bolívar. "Formação de um pensamento político autoritário na Primeira República: uma interpretação." In: Fausto, B., ed., III, v. 1, História Geral da Civilização Brasileira, v. 9: São Paulo, DIFEL, tomo III, v.1, 1977.

. "Comportamento eleitoral em São Paulo: passado e presente". In: CARDOSO, Fernando Henrique; LAMOUNIER, Bolívar. Os partidos e as eleições no Brasil. Rio de Janeiro: Editora Paz e Terra, 1978.

CARNEIRO, Dionísio Dias e ABREU, Marcelo de Paiva. 50 anos de Brasil, 50 anos de Fundação Getúlio Vargas. Rio de Janeiro: Editora FGV, 1994.

LAVAREDA, José Antônio. A democracia nas urnas: o processo partidário eleitoral brasileiro. Rio de Janeiro, RJ: IUPERJ: Rio Fundo Editora, 1991. 
LEAL, Victor N. Coronelismo, enxada e voto. Rio de Janeiro: Revista Forense, 1948.

LEME, Marisa S. A ideologia dos industriais brasileiros, 1919-1945. Petrópolis: Vozes, 1978.

LEVINE, Robert. A Velha Usina. São Paulo: Ed. Paz e Terra, 1980.

LIMA Jr., Olavo Brasil de. Os partidos políticos brasileiros: a experiência federal e regional, 1945-1964. Rio de Janeiro: Graal, 1983.

"A experiência brasileira com partidos e eleições". In: LIMA Jr., Olavo Brasil de. (org) $O$ balanço do poder. Rio de Janeiro: Rio Fundo Editora, 1990.

SANTOS, Fabiano; AMORIM NETO, Otávio. "Fragmentação Eleitoral e Radicalização Ideológica No Rio de Janeiro: Impacto da Política Estadual na Política Nacional (1946-1964)". In: Dados - Revista de Ciências Sociais, Rio de Janeiro, v. 30, n. 2, p. 167-86, 1987.

LOVE, Joseph L. "O Poder dos Estados: Análise Regional". In: FAUSTO, Bóris. História Geral da Civilização Brasileira. São Paulo, DIFEL, Tomo III, ${ }^{\circ}$ vol, 1975a.

$1975 b$.

O regionalismo gaúcho e as origens da revolução de 1930. SP: Perspectiva,

A locomotiva: São Paulo na Federação Brasileira, 1889-1937. Rio de Janeiro: Paz e Terra, 1982.

"Federalismo y Regionalismo en Brasil, 1889-1937." In CARMAGNANI, Marcello (ed). Federalismos Latinoamericanos: México/Brasil/Argentina, Mexico, DF: Fondo de Cultura Económica, 1993.

MARSHALL, Thomas H. Cidadania, classe social e status. Rio de Janeiro: Zahar, 1967.

MARTINS, José de Souza. O Cativeiro da Terra. $8^{\text {a }}$ edição, Ed. Hucitec, 2004.

MARX, Karl. 18 Brumario de Luis Bonaparte. São Paulo: Escriba, 1968.

McCANN, Bryan. "Carlos Lacerda: the rise and fall of a middle-class populist in 1950s Brazil”. In: Hispanic American Historical Review, Pittsburgh, v.83,n.4, November, 2003, pp. 661-696.

MENEGUELlo, Rachel. Partidos e Governos No Brasil Contemporâneo (19851997). São Paulo: Paz e Terra, 1998.

MICELI, Sérgio. "Carne e osso da elite política brasileira pós-1930" In: FAUSTO, Boris (org). História Geral da Civilização Brasileira, v.3, tomo 3, 1989, p.557-96.

MOORE Jr., BARRINGTON. Social Origins of Dictatorship and Democracy: Lord and Peasant in the Making of the Modern World. Beacon Press, 1993. 
MOSCA, Gaetano. México: Fondo de Cultura Económica, 1984.

NEIVA, Pedro R. P. "Os determinantes da existência e dos poderes das câmaras altas: federalismo ou presidencialismo" In: Dados, Rio de Janeiro, v.49, n.2, 2006.

NICOLAU, Jairo. "As distorções na representação dos estados na Câmara de deputados brasileira”. Dados, Rio de Janeiro, v. 40, n. 3, 1997.

"Partidos Políticos na República de 1946: velhas teses, novos dados". Dados,

Rio de Janeiro, v. 47, n. 1, 2004.

NORMANO, João F. Evolução econômica do Brasil. São Paulo: Companhia Editora Nacional, 1939.

NORTH, Douglass. Institutions, institutional change and economic performance. Nova Iorque: Cambridge University Press, 1990.

NUNES, Edson. A gramática política do Brasil: clientelismo e insulamento burocrático. Rio de Janeiro : Jorge Zahar Editor, 1999.

OLIVEIRA, Francisco de. Elegia para uma re(li)gião: SUDENE, Nordeste. Planejamento e conflitos de classes. $3^{\mathrm{a}}$ ed., Rio de Janeiro: Paz e Terra, 1981.

Economia da dependência imperfeita. Rio de Janeiro : Graal, 1989.

. "A metamorfose da arribaçã: fundo público e regulação autoritária na expansão Econômica do nordeste” In: Novos Estudos CEBRAP, n.27, Julho de 1990, p. 67-92.

v.7, n.18, 1994.

"A questão regional: a hegemonia inacabada". Estudos Avançados. São Paulo,

OLIVEIRA, Lúcia Maria Lippi. O Partido Social Democrático. Dissertação de Mestrado - Instituto Universitário de Pesquisas do Rio de Janeiro (IUPERJ), 1973.

PÉCAUT, Daniel. Intelectuais e a política no Brasil: entre o povo e a nação. São Paulo: Ática, 1990.

PELÁEZ, Carlos Manuel. História da Industrialização Brasileira. Rio de Janeiro: APEC, 1972.

PIERSON, Paul. "Increasing Returns, Path Dependence, and the Study of Politics" In: American Political Science Review, v.94, n.2, Junho de 2000.

.. Polítics in time: history, institutions, and social analysis. Princeton: Princeton University Press, 2004.

PRZEWORSKI, Adam. Democracy and the market: Political and economic reforms in eastern Europe and Latin America. New York:Cambridge University Press, 1991. 
. "Democracy as an equilibrium" In: Public Choice, n.123, 2005.

RODRIGUES, Leôncio M. "Sindicalismo e classe operária 1930-1964" In: FAUSTO, Boris (org). História Geral da Civilização Brasileira, v.3, tomo 3, 1989, p.507-56.

SALLUM JR., Brasílio \& KUGELMAS, Eduardo. "O Leviatã acorrentado: a crise brasileira dos anos 80", in SOLA, Lourdes (org.), Estado, mercado e democracia, Rio de Janeiro, Paz e Terra, 1993.

SAMPAIO, Regina. Adhemar de Barros e o PSP. 1a. ed, São Paulo, SP: Global Editora, 1982.

SANTOS, André M. dos. "Sedimentação de Lealdades Partidárias no Brasil: Tendências e Descompassos" In: Revista Brasileira de Ciências Sociais, São Paulo, v. 16, n. 45, p. 69-83, 2001.

SANTOS, Wanderley Guilherme dos. "A práxis liberal no Brasil: propostas para reflexão e pesquisa". In : - Ordem burguesa e liberalismo político. São Paulo: Duas Cidades, 1978.

.. Sessenta e quatro: anatomia da crise. São Paulo: Vértice, 1986.

. "Velhas teses, novos dados: uma análise metodológica". Dados, Rio de Janeiro, v. 47, n. 4, 2004.

SCHUMPETER, Joseph. Capitalismo, socialismo e democracia. Rio de Janeiro: Fundo de Cultura, 1961.

SCHWARTZMAN, Simon. São Paulo e o estado nacional. São Paulo: Difel, 1975.

SHUGART, Mattew e TAAGEPERA, Rein. Seats and Votes: The Effects and Determinants of Electoral Systems. New Haven, Yale University Press, 1989.

SILVA, Hélio. Jânio Quadros, a renúncia. São Paulo: Grupo de Comunicação Três, 1983.

SIMÃO, Azis. "O voto operário em São Paulo". Revista Brasileira de Estudos Políticos, Belo Horizonte: UFMG, n. 1, 1956.

SKOCPOL. Theda. "Bringing the State Back In: Strategies of Analysis in Current Research" In: EVANS, Peter; RUESCHEMEYER, Dietrich e SKOCPOL, Theda (eds.) Bringing the State Back In. Cambridge: University Press, 1985. 106, 1995.

"Why I Am an Historical Institutionalist" In: Polity, v. 28, n. 1, pp. 103-

SOARES, Gláucio. Sociedade e Política no Brasil. São Paulo: Difel, 1973.

. “A formação dos partidos nacionais". In: FLEISCHER (org), Os Partidos Políticos no Brasil. Brasília: Cadernos da UNB v. 2, 1981. 
SOUZA, Maria do Carmo Campello de. Estado e partidos políticos no Brasil: 193064. São Paulo: Alfa-Omega, 1976.

Aspectos políticos-institucionais do federalismo (1930-1964). São Paulo: IESP/FUNDAP, 1993 (relatório de pesquisa, Projeto Federalismo no Brasil).

. "Federalismo no Brasil: aspectos político-institucionais (1930-1964)". Revista Brasileira de Ciências Sociais, São Paulo, v.21, n.61, Junho de 2006.

STEPAN, Alfred. Os militares na política. Rio de Janeiro: Editora Artenova, 1975.

. "Para uma Nova Análise Comparativa do Federalismo e da Democracia: Federações que Restringem ou Ampliam o Poder do Demos" In: Revista Dados, Rio de Janeiro, v.42, n.2, 1999.

TAVARES, Maria da C. "Substituição de importações e desenvolvimento econômico na América Latina" In: Dados, n.1, Rio de Janeiro, 1966, pp.115-40.

TSE, Dados Estatísticos, vols. 6, 8 e 11. TSE, Diário da Justiça, 28 de novembro de 1983.

VASSELAI, Fabricio. "Nomeações ministeriais e importância partidária na democracia de 1946-64: análises comparativas em relação à democracia atual" In: Perspectivas Revista de Ciências Sociais. São Paulo:Editora UNESP, 2009a.

. "Ainda o crescimento eleitoral do PTB na democracia de 1945: características espaciais e nacionalização", 2009b. (Mimeo)

VIANNA, Luiz W. "O sistema partidário e o Partido Democrata Cristão" In: Cadernos Cedec, n.1, São Paulo:Brasiliense, 1978.

.Travessia - da abertura à constituinte. RJ: Livraria Taurus Ed., 1986.

A revolução passiva - iberismo e americanismo no Brasil. Rio de Janeiro: Revan, 1997.

VIANNA, Oliveira. Populações meridionais do Brasil. Rio de Janeiro: José Olympio, 1952.

Problemas de direito corporativo. São Paulo : Ltr, 1987.

VILLELA, Annibal e SUZIGAN, Wilson. Política do Governo e Crescimento da Economia Brasileira. Rio de Janeiro: IPEA/INPES, 1973.

WEBER, Max. "Política como vocação". In: WEBER, Max, Ciência e política: duas vocações. São Paulo: Cultrix, 2004

WEFFORT, Francisco. "Raízes sociais do populismo em São Paulo", In: Revista Civilização Brasileira, n. 2, 1965. 
WEYLAND, Kurt. "Clarifying a contested concept: populism in the study of Latin American politics", In: Comparative Politics, v. 34, n. 1, Outubro de 2001.

WIRTH, John D. Fiel da balança: Minas-Gerais na federação brasileira 1889-1937. Rio de Janeiro: Paz e Terra, 1982.

WOODARD, James P. "All for São Paulo, All for Brazil: Vargas, the Paulistas, and the Historiography of Twentieth-Century Brazi”. In: HENTSCHKE, Jens R. (ed.), Vargas and Brazil: New Perspectives. London: Palgrave Macmillan, 2006. 
Anexo 1 - Recursos desembolsados pelo Banco do Brasil: porcentagem em relação ao total do país

\begin{tabular}{|c|c|c|c|c|c|c|c|c|c|c|c|c|c|c|}
\hline & 1938 & 1944 & 1945 & 1946 & 1947 & 1948 & 1949 & 1950 & 1951 & 1953 & 1955 & 1956 & 1957 & 1958 \\
\hline NE & $20,1 \%$ & $0,0 \%$ & $0,0 \%$ & $0,0 \%$ & $18,7 \%$ & $17,8 \%$ & $18,4 \%$ & $19,2 \%$ & $18,6 \%$ & $17,8 \%$ & $13,9 \%$ & $14,2 \%$ & $12,6 \%$ & $11,6 \%$ \\
\hline MG & $5,2 \%$ & $15,6 \%$ & $15,5 \%$ & $15,0 \%$ & $12,3 \%$ & $9,8 \%$ & $9,3 \%$ & $9,7 \%$ & $8,0 \%$ & $9,7 \%$ & $8,5 \%$ & $8,3 \%$ & $8,9 \%$ & $8,8 \%$ \\
\hline $\mathrm{SP}$ & $24,1 \%$ & $27,2 \%$ & $28,7 \%$ & $18,9 \%$ & $20,5 \%$ & $22,2 \%$ & $20,7 \%$ & $27,6 \%$ & $32,2 \%$ & $31,9 \%$ & $34,9 \%$ & $34,5 \%$ & $37,2 \%$ & $36,2 \%$ \\
\hline RJ & $2,8 \%$ & $2,0 \%$ & $2,4 \%$ & $2,6 \%$ & $2,5 \%$ & $2,5 \%$ & $2,7 \%$ & $2,3 \%$ & $2,6 \%$ & $2,8 \%$ & $2,2 \%$ & $2,3 \%$ & $2,1 \%$ & $2,1 \%$ \\
\hline DF & $37,4 \%$ & $23,9 \%$ & $15,9 \%$ & $22,8 \%$ & $28,7 \%$ & $32,5 \%$ & $33,8 \%$ & $25,0 \%$ & $21,0 \%$ & $19,2 \%$ & $16,7 \%$ & $16,7 \%$ & $15,5 \%$ & $15,5 \%$ \\
\hline $\mathrm{RS}$ & $5,9 \%$ & $5,6 \%$ & $6,3 \%$ & $7,0 \%$ & $7,9 \%$ & $6,0 \%$ & $6,8 \%$ & $7,3 \%$ & $9,1 \%$ & $7,6 \%$ & $11,2 \%$ & $12,3 \%$ & $11,4 \%$ & $11,7 \%$ \\
\hline
\end{tabular}

$\begin{array}{lrrrrrrrrr} & 1984 & 1985 & 1986 & 1987 & 1988 & 1989 & 1990 & 1991 & 1992 \\ & & & & & & & & & \\ \text { NE } & 12,9 \% & 10,2 \% & 12,1 \% & 17,2 \% & 10,6 \% & 4,8 \% & 5,9 \% & 9,7 \% & 8,9 \% \\ \text { MG } & 8,1 \% & 6,4 \% & 9,0 \% & 10,0 \% & 6,8 \% & 13,1 \% & 8,8 \% & 8,8 \% & 8,6 \% \\ \text { SP } & 20,4 \% & 22,5 \% & 22,4 \% & 21,2 \% & 20,8 \% & 17,7 \% & 15,1 \% & 15,0 \% & 14,3 \% \\ \text { RJ } & 3,2 \% & 4,6 \% & 2,1 \% & 3,5 \% & 5,1 \% & 15,5 \% & 20,9 \% & 22,6 \% & 5,6 \% \\ \text { DF } & 0,7 \% & 8,1 \% & 5,9 \% & 1,6 \% & 0,0 \% & 0,0 \% & 0,0 \% & 1,1 \% & 1,4 \% \\ \text { RS } & 22,4 \% & 17,8 \% & 14,7 \% & 15,6 \% & 18,2 \% & 13,9 \% & 23,8 \% & 13,0 \% & 20,0 \%\end{array}$

\begin{tabular}{|c|c|c|c|c|c|c|c|c|c|c|c|}
\hline & 1994 & 1995 & 1996 & 1997 & 1998 & 1999 & 2000 & 2002 & 2003 & 2004 & 2005 \\
\hline NE & $6,4 \%$ & $8,5 \%$ & $11,6 \%$ & $13,3 \%$ & $8,6 \%$ & $4,8 \%$ & $7,2 \%$ & $14,2 \%$ & $13,8 \%$ & $15,0 \%$ & $14,9 \%$ \\
\hline$M G$ & $4,6 \%$ & $6,5 \%$ & $10,5 \%$ & $12,5 \%$ & $12,4 \%$ & $12,9 \%$ & $9,6 \%$ & $9,7 \%$ & $9,6 \%$ & $9,6 \%$ & $9,8 \%$ \\
\hline SP & $33,9 \%$ & $37,6 \%$ & $26,6 \%$ & $16,3 \%$ & $15,6 \%$ & $10,5 \%$ & $11,9 \%$ & $28,8 \%$ & $28,5 \%$ & $26,7 \%$ & $27,7 \%$ \\
\hline RJ & $2,5 \%$ & $2,9 \%$ & $3,2 \%$ & $2,3 \%$ & $1,4 \%$ & $0,7 \%$ & $4,2 \%$ & $8,0 \%$ & $8,2 \%$ & $7,9 \%$ & $8,8 \%$ \\
\hline DF & $1,6 \%$ & $4,2 \%$ & $2,8 \%$ & $2,2 \%$ & $3,0 \%$ & $0,9 \%$ & $4,1 \%$ & $3,2 \%$ & $4,0 \%$ & $4,2 \%$ & $4,1 \%$ \\
\hline $\mathrm{RS}$ & $13,7 \%$ & $9,7 \%$ & $13,3 \%$ & $13,3 \%$ & $14,7 \%$ & $21,1 \%$ & $17,1 \%$ & $10,0 \%$ & $9,7 \%$ & $9,2 \%$ & $9,0 \%$ \\
\hline
\end{tabular}

Fonte: Anuários Estatísticos do Brasil, vários anos. 


\section{Anexo 2 - Identificação da área de atuação a qual pertence cada} ministério

Nome do Ministério:

M. da Aeronáutica

M. da Agricultura

M. da Educação e Cultura

M. da Educação e Saúde Pública

M. da Fazenda

M. da Guerra

M. da Indústria e do Comércio

M. da Justiça e Negócios Interiores

M. da Marinha

M. da Saúde

M. das Minas e Energia

M. das Relações Exteriores

M. de Viação e Obras Públicas

M. do Trabalho e Previdência Social

M. do Trabalho, Indústria e Comércio
Área:

Política

Econômica

Social

Social

Econômica

Política

Econômica

Política

Política

Social

Econômica

Política

Econômica

Social

Social

Nome do Ministério:

Área:

M. da Ação Social

Social

M. da Administração e Reforma do Estado

Político

M. da Agricultura

Econômico

M. da Assistência Social

Social

M. da Ciência e Tecnologia

Econômico

M. da Cultura

Social

M. da Defesa

Político

M. da Desburocratização

Político

M. da Educação

Social

M. da Fazenda

Econômico 


$\begin{array}{ll}\text { M. da Indústria e Comércio } & \text { Econômico } \\ \text { M. da Infra-estrutura } & \text { Econômico } \\ \text { M. da Integração Nacional } & \text { Econômico } \\ \text { M. da Integração Regional } & \text { Econômico } \\ \text { M. da Justiça } & \text { Político } \\ \text { M. da Previdência e Assistência Social } & \text { Social } \\ \text { M. da Reforma e do Desenvolvimento Agrário } & \text { Político } \\ \text { M. da Saúde } & \text { Social } \\ \text { M. das Cidades } & \text { Social } \\ \text { M. das Comunicações } & \text { Econômico } \\ \text { M. das Minas e Energia } & \text { Econômico } \\ \text { M. das Relações Exteriores } & \text { Político } \\ \text { M. do Bem Estar Social } & \text { Social } \\ \text { M. do Desenvolvimento Agrário } & \text { Social } \\ \text { M. do Desenvolvimento Social } & \text { Social } \\ \text { M. do Desenvolvimento Urbano, Habitação e Meio Ambiente } & \text { Social } \\ \text { M. do Interior } & \text { Econômico } \\ \text { M. do Meio Ambiente } & \text { Social } \\ \text { M. do Planejamento } & \text { Político } \\ \text { M. do Trabalho } & \text { Social } \\ \text { M. do Trabalho e Administração } & \text { Social } \\ \text { M. do Trabalho e Previdência Social } & \text { Social } \\ \text { M. do Turismo } & \text { Econômico } \\ \text { M. dos Assuntos Extraordinários } & \text { Político } \\ \text { M. dos Esportes e Turismo } & \text { Social } \\ \text { M. dos Transportes } & \text { Econômico } \\ \text { M. Extra do Combate à Fome } & \text { Social } \\ \text { M.dos Transportes e Comunicação } & \text { Econômico }\end{array}$

